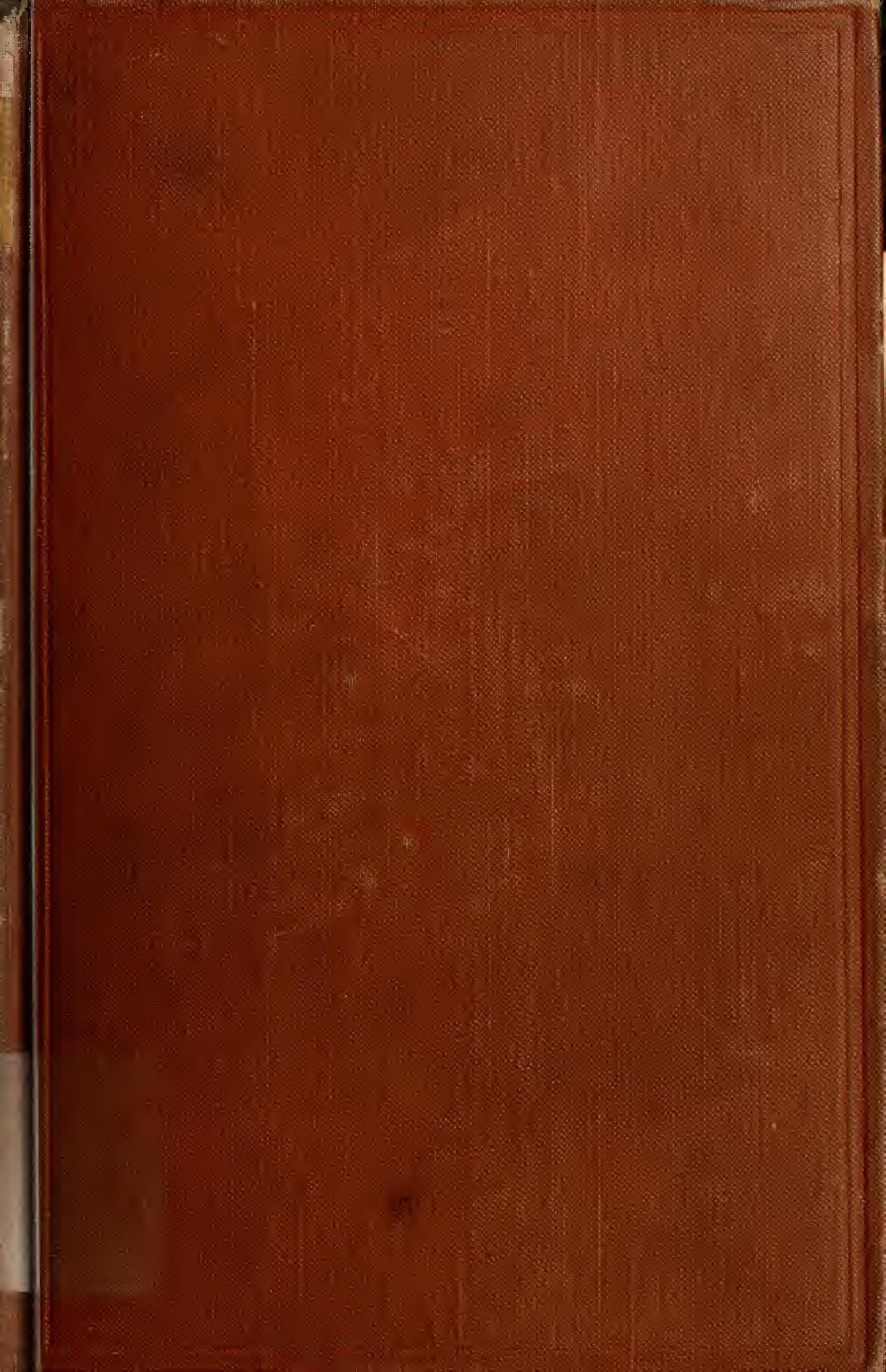




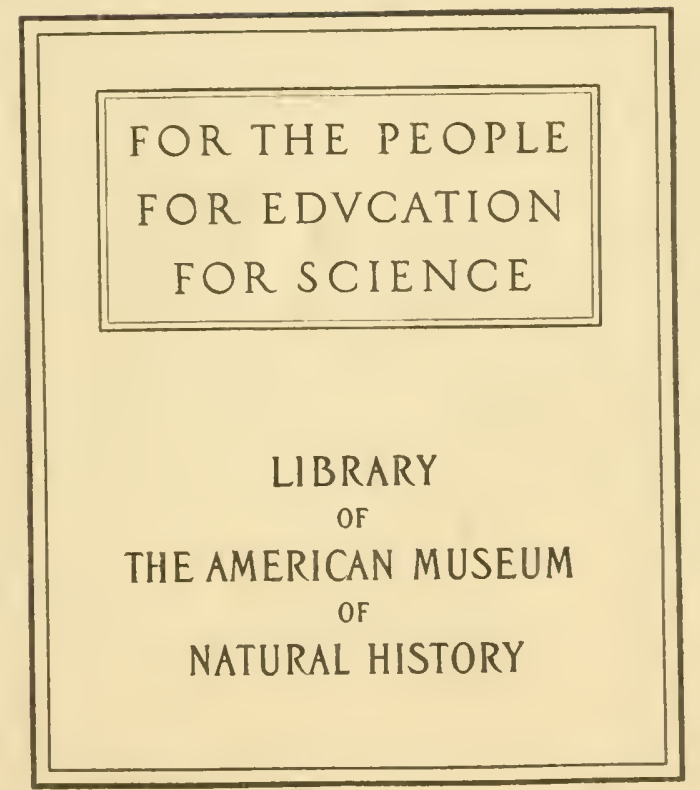







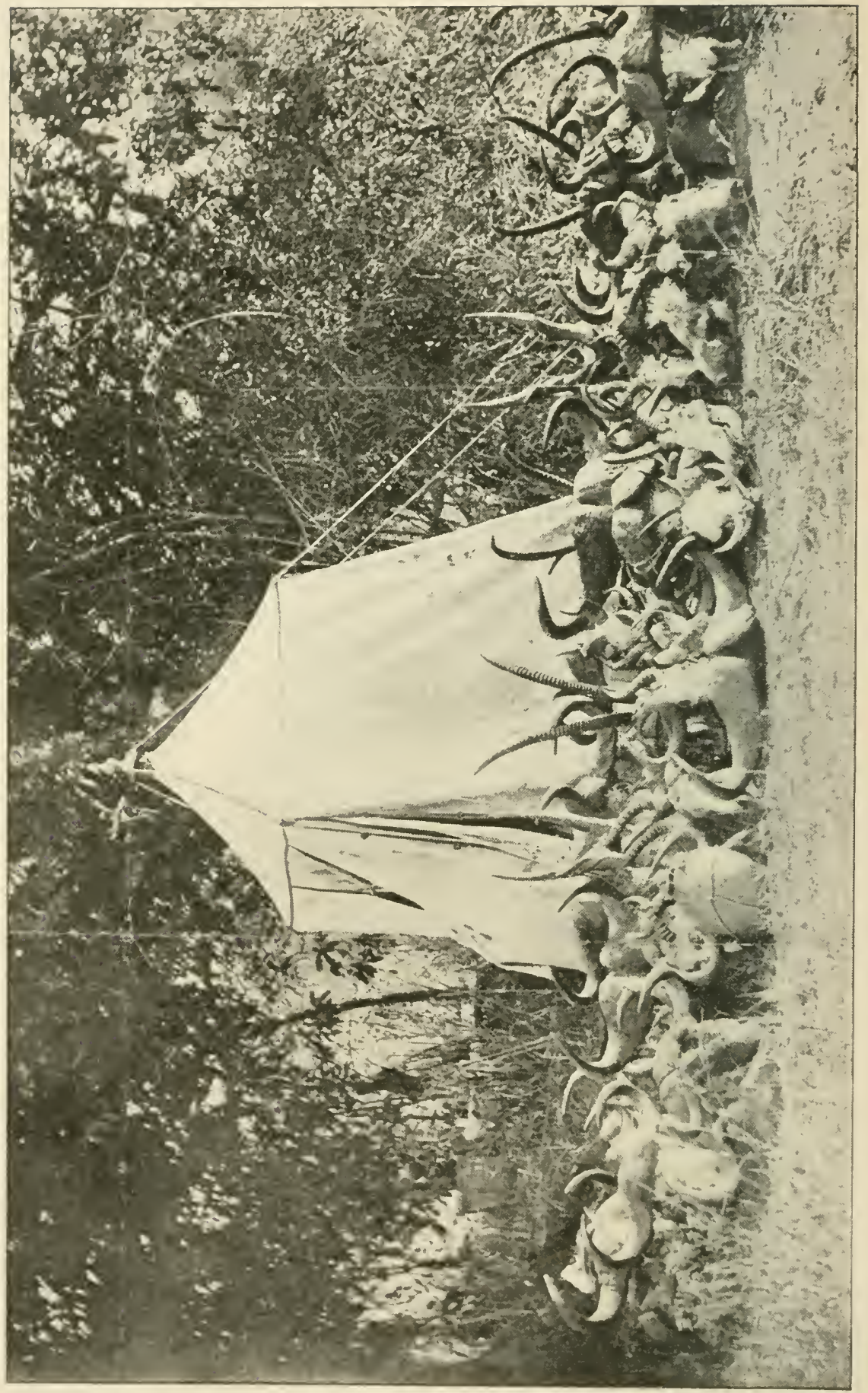

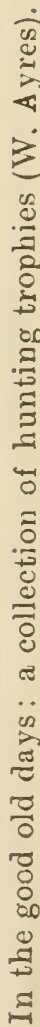




\section{SOUTH AFRICAN MAMMALS}

A SHORT MANUAL FOR THE USE OH FIELD NATURALISTS, SPORTSMEN AND TRAVELLERS

BY

ALWIN HAAGNER, F.Z.S., \&.

Director National Zoological Gardens of South Africa;

Fresident Transvaal Game Protection Association; Vice-President S. A. Biological Society;

Joint Eatitor S. A. Journal of Natural History

WITH NUMEROUS ILLUSTRATIONS

LONDON :

H. F. \& G. WITHERB I

326 HIGH HOLBORN, W.C.

CAPE TOWN :

T. MASKEW MILLER

$2 !$ ADDERLEY STREET

1920 


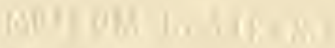

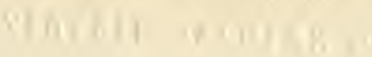

21. 24257 . Man. 16 ๕. 
TO THE

MEMBERS OF THE COMMITTEE OF MANAGEMENT

OF THE NATIONAL ZOOLOGICAL GARDENS OF SOUTH AFHICA, PHETORIA, TRANSVAAL 



\section{T'ABLE OF CONTEN'T'.}

$\begin{array}{llllllll}\text { Table of Contents } & \ldots & \ldots & \ldots & \ldots & \ldots & \text { ix }\end{array}$

$\begin{array}{llllllll}\text { List of IlluUstrations } & \ldots & \ldots & \ldots & \ldots & \ldots & \text { xi }\end{array}$

$\begin{array}{lllllllll}\text { INTRODUCTION } & \ldots & \ldots & \ldots & \ldots & \ldots & \ldots & \mathrm{XV}\end{array}$

$\begin{array}{lllllll}\text { General Principles of Zoology } & \ldots & \ldots & \ldots & \ldots & 1\end{array}$

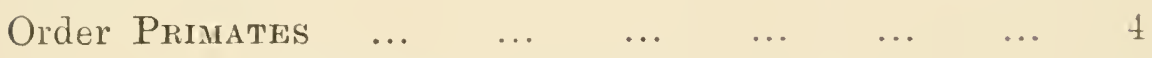

Family Cercopitheciàie $\quad \ldots \quad \ldots \quad \ldots \quad \ldots \quad t$

$\begin{array}{lllllll}\text {, } & \text { Lemuridæ } & \ldots & \ldots & \ldots & \ldots & 17\end{array}$

$\begin{array}{lllllllll}\text { Order Chiroptera } & \ldots & \ldots & \ldots & \ldots & \ldots & \ldots & 21\end{array}$

$\begin{array}{lllll}\text { Family Pteropodidx } & \ldots & \ldots & \ldots & 22\end{array}$

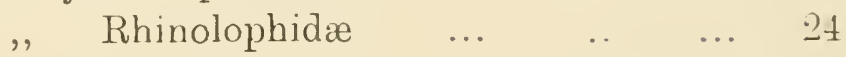

$\begin{array}{lllllll} & \text { "Nycteridæ } & \ldots & \ldots & \ldots & \ldots & 25\end{array}$

$\begin{array}{llllll} & \text {, Vespertilionidæ } & \ldots & \ldots & \ldots & 25\end{array}$

$\begin{array}{llllll}\text {,, Emballonuridæ } & \ldots & \ldots & \ldots & 26\end{array}$

$\begin{array}{llllllll}\text { Order Insectivora } & \ldots & \ldots & \ldots & \ldots & \ldots & \ldots & 27\end{array}$

$\begin{array}{lllll}\text { Family Macroscelid } x & \ldots & \text {.. } & \ldots & 27\end{array}$

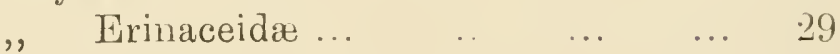

$\begin{array}{lllllll} & \text { "Soricidæ } & \ldots & \ldots & \ldots & \ldots & 30\end{array}$

$\begin{array}{lllll}\text { ", Chrysochloridæ } & \ldots & \ldots & \ldots & 33\end{array}$

$\begin{array}{llllllll}\text { Order Carnivotia } & \ldots & \ldots & \ldots & \ldots & \ldots & \ldots & 30\end{array}$

$\begin{array}{llllll}\text { Family Mustelidæ } & \ldots & \ldots & \ldots & \ldots & 35\end{array}$

$\begin{array}{lllllll}\text {, } & \text { Canidæ } & \ldots & \ldots & \ldots & \ldots & 41\end{array}$

$\begin{array}{lllllll}\text {, } & \text { Hyaenidæ } & \ldots & \ldots & \ldots & \ldots & 49\end{array}$

$\begin{array}{lllllll}, & \text { Viverridæ } & \ldots & \ldots & \ldots & \ldots & 5\end{array}$

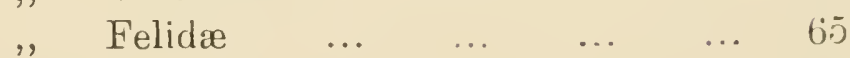

$\begin{array}{lllllllll}\text { Order Pinnipedia } & \ldots & \ldots & \ldots & \ldots & \ldots & \ldots & 52\end{array}$

$\begin{array}{llllll}\text { Family Otariid } x & \ldots & \ldots & \ldots & \ldots & S 2\end{array}$

$\begin{array}{lllllll}\text { " } & \text { Phocidx } & \ldots & \ldots & \ldots & \ldots & \$ 4\end{array}$ 
Order Rodentia

Family Sciuridiz

,, Gliridæ

, Muridæ

89

91

", Bathyergilie

99

" Pedetidie .

" Octodontidie

," Hystricidæ ...

, Leporidie ...

Order Hyracordea; Family Procavidie ...

$\begin{array}{lllllllll}\text {, } & \text { Ungulata } & \ldots & \ldots & \ldots & \ldots & \ldots & \ldots & 124\end{array}$

$\begin{array}{llllll}\text { Sub-Order Perissodactyla } & \ldots & \ldots & \ldots & 124\end{array}$

Family Rhinocerotidæ $\quad \ldots \quad \ldots \quad \ldots \quad \ldots \quad 124$

$\begin{array}{llllllll}\text {, } & \text { Equidx } & \ldots & \ldots & \ldots & \ldots & 129\end{array}$

$\begin{array}{llllll}\text { Sub-Order Artiodactyla } & \ldots & \ldots & \ldots & \ldots & 142\end{array}$

$\begin{array}{llllll}\text { Family Suidæ } & \ldots & \ldots & \ldots & \ldots & 142\end{array}$

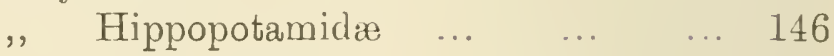

$\begin{array}{llllll}\text {,, } & \text { Ruminantia... } & \ldots & \ldots & \ldots & 152\end{array}$

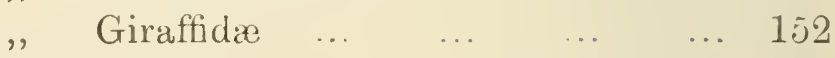

$\begin{array}{llllll}\text {,. Bovidæ } & \ldots & \ldots & \ldots & \ldots & 156\end{array}$

Sub-Family Bubalinæ... $\quad \ldots \quad \ldots \quad 157$

Cervicapridæ $\quad \ldots \quad \ldots \quad 184$

$\begin{array}{lllll}\text { Bovinæ } & \ldots & \ldots & \ldots & 225\end{array}$

$\begin{array}{lllllllll}\text { Order SiRenta } & \ldots & \ldots & \ldots & \ldots & \ldots & \ldots & 230\end{array}$

$\begin{array}{lllllllll}\text { "Cetacea } & \ldots & \ldots & \ldots & \ldots & \ldots & \ldots & 232\end{array}$

Sub-Order Mystacoceti $\ldots \quad \ldots \quad \ldots 32$

", Odontoceti $\quad \ldots \quad$.. $\quad$.. $\quad \ldots \quad 234$

$\begin{array}{lllllllll}\text { Order Edentata } & \ldots & \ldots & \ldots & \ldots & \ldots & \ldots & 236\end{array}$

$\begin{array}{llllll}\text { Family Manıdie } & \ldots & \ldots & \ldots & \ldots & 236\end{array}$

$\begin{array}{llllll} & \text {, Orycteropodidie } & \ldots & \ldots & \ldots & 237\end{array}$

$\begin{array}{llllllllll}\operatorname{INDEX} . . . & \ldots & \ldots & \ldots & \ldots & \ldots & \ldots & \ldots & 2 \neq 0\end{array}$ 


\section{LIS'T' OF ILLUS'TRA'TIONS.}

Frontispiece-In the Good Old Days.

W. Ayres

FIG.

F. Pollard $\quad$. $\quad 6$

1 Albino Vervet Monkey .. .. . .

S.A. Railways . 10

2 Yellow Baboon . $\quad$.. $\quad$. $\quad$.

A. K. Haagner.. 12

4 Rhodesian Baboon $\quad$.. $\quad$.. $\quad$.

F. Pollard ․ 15

$\begin{array}{llllllllll}5 & \text { Grey Shrew } & \ldots & \ldots & \ldots & \ldots & \text { R. H. Iry } & \ldots & 32 \\ 6 & \text { Albino Shrew } & \ldots & \ldots & \ldots & \ldots & ,, & , & \ldots & 32\end{array}$

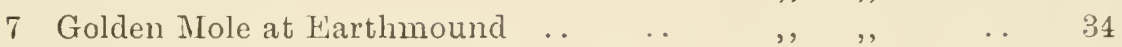

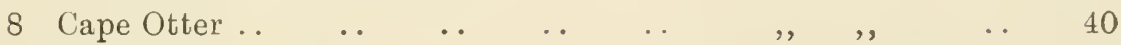

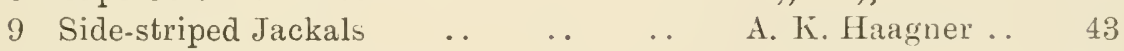

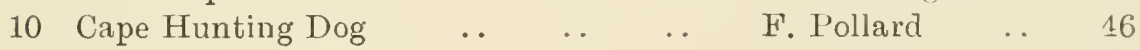

11 Cape Long-eared Foxes .. $\quad \ldots \quad$. $\quad$ C. J. Swierstra.. 47

$12 \quad, \quad, \quad$, , and young .. $\quad$ A. K. Haagner .. 47

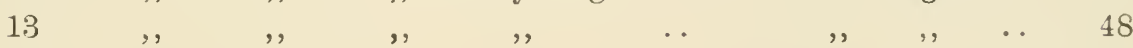

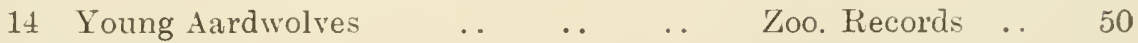

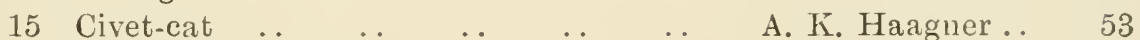

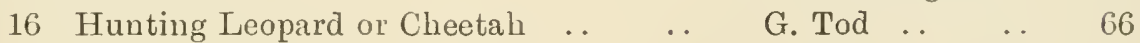

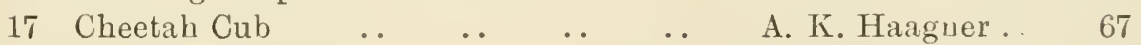

18 Black-maned Lion $\quad \ldots \quad$.. $\quad \ldots \quad$ A. H. Giovanetti 69

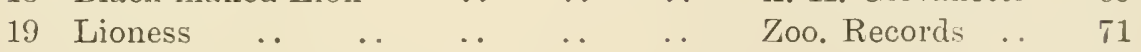

20 Lion Cubs : 6 weeks old .. $\quad \ldots \quad$.. $\quad$ A. K. Haagner.. 72

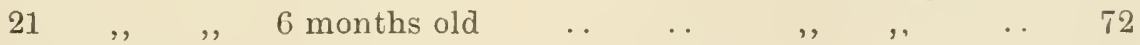

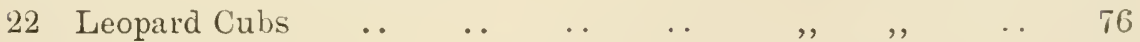

23 Leopard (female) .

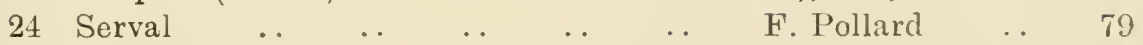

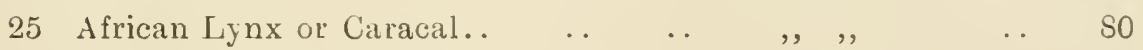

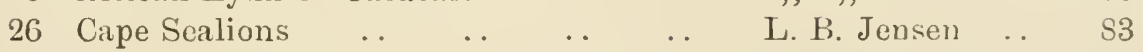

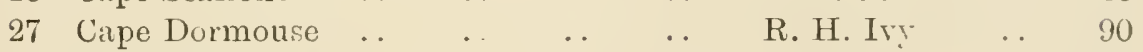

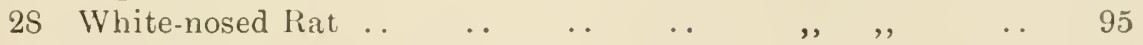

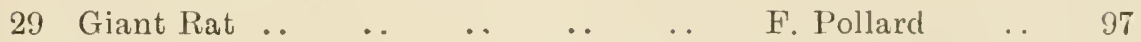

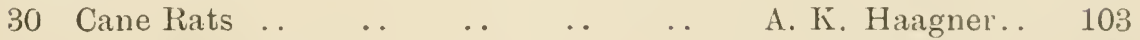

31 Albino Porcupine.. $\quad$.. $\quad$.. $\quad$.. $\quad$ Zoo. Records . 104

32 Porcupines and Young .. $\quad \ldots \quad$. . $\quad$ A. K. Haagner.. 105

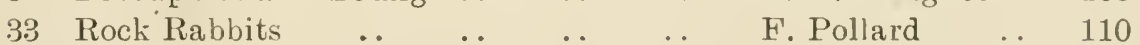

34 S. African Elephant (Head) _. $\quad$.. $\quad$ A. H. Giovanetti 112

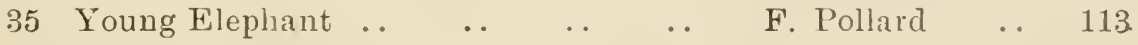


Training a Young Elephant: After six months .. . ., 122

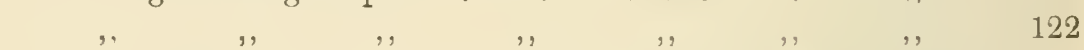


83 Bontebuck Ram ..

A. H. Giovanetti 161

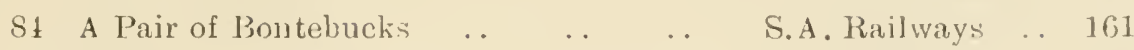

Blesbuck in the $\%$ oo. . . . . . .

A. K. Haagner .. 16,3

Capturing Blesbuck on the Veld ..

, . . . . 16,4

87 Jlesbuck and Springbok Shoot in the O.F.S.

$\begin{array}{llll}88 & \text { Tsessebi or Sassaby } & \text {.. } & \text {. } \\ 89 & \text { Brindled (inu or Blue Vildebeest }\end{array}$

,, , , . 164

$90,,,,$, .

Maj. C. E. FitzRoy 165

91 White-tailed Gnu or Black Wildebeest

A. H. Giovanetti 167

Maj. C. E. FitzRoy 167

$92 \quad,, \quad, \quad$ : a Bag in the O.F.S.

A. H. (riovanetti 169

A. K. Haagner .. 170

93 Blue Duiker or Pietie . . . . . .

94 Common Duiker" a Bushveld "Bag ",

95 Albino Duiker . . $\quad$. $\quad$.. $\quad$.

96 Klipspringer (Ram) _. $\quad \ldots \quad \ldots$

97 A Pair of Oribis . . . . . . $\quad$..

98 "Fufwa," N. Rhodesian: the Home of the Oribi

99 Lechwes Feeding ..

100 Lechwe fram

101 Puku Ram ..

102 Briuging in a Dead Puku

10:3 Reedbuck and Bushbuck

$10 \pm$

Taal Rhebuek .. .

..

Impalas in the Zoo.

106 Dead Impala Ram

107 A Pair of Springbuck

108 Young Springbuck

109 Springbuck Rams sparring

110 A Fine Springbuck Ram

111 Dead Roan Antelope

112 Sable Antelopes and Young One A Pair of Sable Antelopes .

Baby Sable Antelope ..

115 Dead Sable Antelope I3ull

,, , . . 173

,, ., . . 174

VWm. Harvey .. 175

A. K. Haagner .. 177

E. A. O. Pyin .. 179

A. K. Haagner . 179

," , . . 186

Maj. C. E. FitzRoy 157

," , . . 185

, , . . . 188

F. А. O. Pуm _. 190

A. K. Haaguer .. 192

S.A. Railways .. 194

F. A. U. Pym _. 194

A. H. Giovanetti 196

,, , , . 197

A. K. Haagner . 197

," ., . 198

Iraj. C. E. FitzRoy 200

S.A. Railivays .. 202

A. H. Giovanetti 203

A. K. Haagner .. 203

116 Gemsbuck Bull .

117 Freshly captured Gemsbuck and Eland

118 Cape Bushbuck . . $\quad$. . $\quad \ldots \quad$..

IIaj. C. E. FitzRoy 204

A. K. Haagner .. 206

C. J. van Rooyeu 206

Tom Jenkins .. 208

119 Horns of Female Bushbuck _. $\quad$.. $\quad$ F. O. Noome . . 209

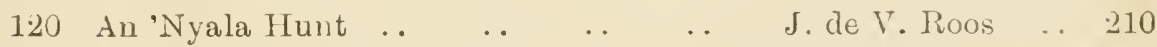

121 A Fine Series of 'Nyala Horns .. $\quad$. $\quad$ F. O. Noome . . 211

122 Record Pair of 'Nyala Horns . . . . $\quad$, $\quad, \quad$, . 213

123 Sitatunga Ram . . $\quad \ldots \quad$. $\quad \ldots \quad \ldots \quad$ A. H. Giovanetti 214

124 Young Sitatunga Ewe $\quad \ldots \quad$. $\quad \ldots \quad \ldots \quad$ Ben Woest $\quad \ldots \quad 215$

125 Koodoo surprised in his Home .. Lent by. C. G. Finch-Davies 217

126 A Koodoo Family .. . . . . . . . A. K. Haaguer .. 218

127 A Young Koodoo Bull . $\quad$. $\quad \ldots \quad \ldots \quad$ F. Pollard $\quad \ldots \quad 218$

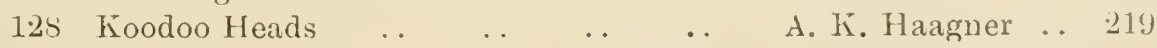

129 Albino Koodoo .. . . . . Lent by C. G. Finch-Davies 220

130 Unstriped Eland Bull . . $\quad \ldots \quad$.. $\quad$ A. K. Haagner .. 221 
xiv.

FIG.

PAGE

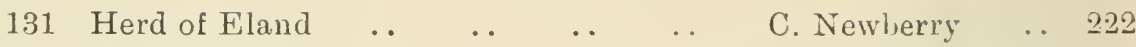

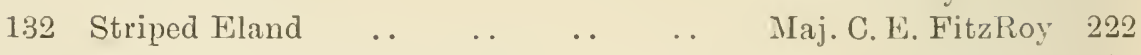

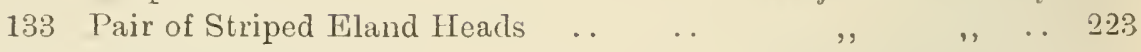

134 Young Striped Eland .. $\quad$. $\quad$. $\quad$ Zoo. Records _. 224

135 Young African Buffalo .. $\quad$. $\quad$.. $\quad$ A. K. Haagner .. 225

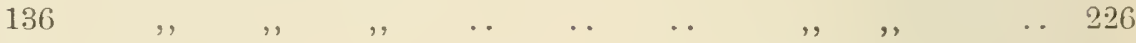

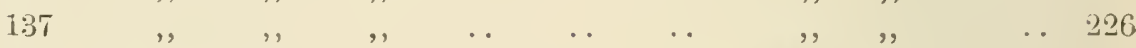

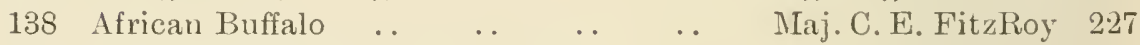

139 Head of Buffalo packed on Bullock .. $\quad, . \quad, \quad$, $\quad 227$

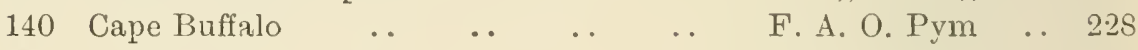

$1+1$ Aardvark or Antbear . . $\quad \ldots \quad \ldots \quad$ F. Pollard $\quad$.. 238 


\section{INTRODUC'TION.}

South Africa has been, from the early days of its emergence from a simple home for savages, the happy hunting grounds of sportsmen from all over the world, and, alas! the ruthless shooting down of game by biltong hunters, game-butchers, and the like, inadequate game laws, with still more inadequate means of enforcing them - coupled with an epidemic some years ago, called the rinderpest - have sadly diminished our noble gameanimals.

In parts of Cape Colony, Koodoo, Elephant, and Buffalo are still to be found, the two former in Albany and the North-western Districts, while all three animals still inhabit the Addo Bush and the Knysna Forests. Buffalo may still be located in the thick bush near Port Alfred as well. Elephant and Buffalo are now Royal Game, but may be shot on a special permit, if found destroying crops. Koodoo can be shot on a special licence.

Since these lines were penned, the Cape Govermment has signed the death-warrant of the Addo herd of Elephants, and Major Pretorious, D.S.O., of East African fame, has been engaged to exterminate this monument of Nature. All the efforts of the 'Iransvaal Game Protection Association and various scientific bodies in South Africa could not budge the members of the Provincial Council. What the author of this work takes such strong 
exception to is the proposed total extinction of the herd. Surely a few females and a young bull could do no harm, especially after having had the wits scared out of them!

In the mountain regions of Cradock, Oudtshoorn, and George, the Mountain Zebra is still to be found, and a permit-fortunately now not easily obtainable-is required to shoot or capture them. Probably not more than 400 are still left alive.

On one or two farms in the Bredasdorp district of the Cape Province, Bontebok still linger in a semi-domesticated state, but were it not for the praiseworthy efforts of the Albertyns and the Van der Byls, this pretty Antelope would long since belong to the past, in company with the true Bluebuck and the Quagga.

In parts of the Orange Free State, especially in the Vinburg, Kroonstad, Hoopstad, and Boshof districts, herds of Black Wildebeest, Blesbuck, and Springbuck still roam the flats-but, alas! not in the countless numbers of Baldwin's and Gordon Cumming's days. Even during the last eight or nine years their numbers have sadly diminished, owing to wanton and indiscriminate shooting for the markets; happily this lamentable state of affairs is being recognized, and attempts are being made to remedy the evil, even at the eleventh hour. In the Cape, 'Transvaal, and Natal, and even in Rhodesia, Game Reserves exist in which our beantiful Antelope are steadily increasing. Some farmers, too, are beginning to realize what an asset game is to their farms, and do not now ruthlessly mow down their Buck in hundreds for the sake of the biltong and skins, as their predecessors did fifteen or twenty years ago.

There are, however, still some who allow butcherssportsmen they cannot be called-to shoot down everything within their reach for a few pounds per amum for 
the sole purpose of making profit out of the game on the Johannesburg and Kimberley markets. We know of one case in a certain village in the Free state where a man and his sons had the shooting rights on a farm teeming with game, and, although fairly well-to-do people, this family party sent up to the Johannesburg market hundreds of head of game every month, until the constant inroad upon the supply caused a total destruction of all game on that particular farm !

I am, of course, not against the legitimate sportsman who is naturalist and sportsman enough to recognize the iacts aforementioned and who is often quite willing to pay for a few days' shooting. I sincerely hope farmers and landowners will realize the important fact that the game is not merely their property, but that it is an asset to the country and belongs quite as much to their heirs and successors.

I have given a good deal of thought to this rexed question, and the only practical solution of the problem I can think of, without waiting until most of the Antelope have to be totally protected, by being proclaimed Royai Game, is the prohibition of the sale of game-meat on the marliets, or by wholesale butchers, except in certain instances, such as Springbuck and similar cases where the animal is plentiful, when a special permit from the Administrator should be allowed for sportsmen to shoot or remove game in certain quantities from one Province to another, or to his home, upon a certificate from the Pesident Magistrate of the district in which he has been shooting. At any rate, something drastic will soon have to be done. 'There are in South Africa a number of people-chiefly Boers-to whom the "sport" of shooting does not appeal. They only shoot for the pot, and to them such ideas as not shooting a Partridge on the 
x viii.

ground, \&c., seems farcical. 'These men will not realize that the game is either Govermment or private property, and they look upon poaching as legitimate "sport." It is largely the poacher-in and out of season-who is causing the scarcity of game, and, in order to try and stop him, the author appeals to all shooting men with sporting instincts in this country to join the Game Protection Associations, or, at least, to report all cases of illegal shooting which come to their notice.

I am not a rabid protectionist, and do not advocate the "protect at any price" theory, or the protection of birds and animals when these are destructive to crops, or are otherwise detrimental to the interests of the human race. I admit the wisdom of their destruction or confinement to some circumscribed area, but before drastic action is taken let us be sure of our facts.

For this reason $I$ an at present against the wholesale and indiscriminate slaughter of the game animals in large areas in Zululand, and the total extermination of the Addo Elephants. When they are once gone, nothing can bring them back, and the men who advocate and sanction such acts without full justification and without exhaustive inquiry are taking a grave responsibility on their own shoulders.

This is also the opinion of one of the leading American authorities.

This book has therefore been written with a threefold object: Besides being an introduction to the study of South African mammals, this work is also intended as a short manual for the use of sportsmen and travellers and the amateur naturalist generally.

As the author has spent twelve years amongst wild animals in the National Zoological Gardens, it is also hoped the work may be of some assistance to the workers 
amongst living wild animals in South Africa and elsewhere; and to this end I have included remarks upon their feeding and treatment in captivity, as well as some of my personal experiences.

To my critics I would point out: firstly, to the zoologist, that while I could have made the work much more "scientific," I would, in so doing, have defeated my main object; and to the literary critic, that I have purposely adopted a more or less "note-book" style, considering this quite adequate for a work of this nature, and the saving of space being to-day a big consideration.

Nany of the illustrations in this book are from life, either from animals in the National Zoological Gardens or in the field. As it is often not possible to photograph the living animal in its native wilds, I have included pictures of dead game animals as they fell in the field, to show more or less the nature of the country they inhabit.

My thanks are due to Mr. W. L. Sclater. M.A., of London (one time Director of the South African Museum in Cape 'Town) for so kindly undertaking the revision of the proofs for me; to His Worship the Mayor of Pretoria (Mr. C. W. Giovanetti) for placing at my disposal the photographs of his son, the late Lieutenant Giovanetti, of the Royal Flying Corps; to Major C. E. FitzRoy, of His Excellency's Staff, for the loan of a number of interesting photographs of game-trophies in the field; to Mr. P. Viana-Rodrigues (Administrator of Maputoland) for an interesting series of photographs of wild and tame Elephants; to the African Film Productions, Ltd., Johannesburg, for the loan of a photo of wild Elephants in the bush; to Dr. A. A. Schoch, of the Transvaal AttorneyGeneral's Office, for a number of weights of game taken, often at great inconvenience, in the field: also for the 
loan of photos to Mr. L. B. Jensen, of Johannesburg; Mr. J. de V. Roos (Auditor-General), J. R. Ivy, and R. H. Try, of Pretoria; to Lieutenant C. G. FinchDavies, 1st S.A.M.R., F. O. Noome, and C. J. Swierstra, of the Transvaal Museum ; to Frank Pym, of the Kingwilliamstown Museum; the S. A. Railway's (Pubicity Dept.); Ivan Ayres; G. Tod; P. Hoogland; Percy Clark; Moe Bros.; C. J. vall Rooyen; Dr. Pirow; Mr. Harvey of Bindura, S. Rhodesia; 'T'. Jenkins; Ben Woest, and to the Zoological Society of London for kind permission to reproduce a photograph of the now extinct Quagya.

I have to acknowledge having made free use of Rowland Ward's "Records of Big Game," 1914 Edition, for the record measurements; but a number of new records have been established since the issue of this work. To these I have added the name of the owner, or the authority for the measurements given.

I am also indebted to Mr. W. L. Sclater's "Mammals of South Africa" for much information. 


\section{SOU'TH AFRICAN MAMMALS'}

A Short MANUAL FOR THE USE OF FIELD NATURALISTS, SPORTSMEN AND TRAVELLERS.

\section{General Principles of Zoologr.}

BEFORE proceeding to the individual descriptions of the quadruped animals or mammals found in South Africa, a short account of the principles of zoology may not be out of place.

Animals form the great division in Nature termed the "Animal Kingdom," in opposition to the "Vegetable" and "Mineral" Kingdoms. A concise and exact definition of an animal is not easy. Linnæus, the first systematist who reduced the chaos existing in his time to something like order, wrote the following as his description: "Stones grow; vegetables grow and live; animals grow, live and feel." Rymer Jones, in his "Natural History of Animals," vol. i, gives us another definition: "Animals are possessed of an internal receptacle for food wherein they collect the nutriment destined for their support."

The Animal Kingdom may roughly be divided into two great groups, the Vertebrate (or animals possessing a vertebral column or backbone) and the Invertebrate (animals without this appendage). The full classification in modern use is too long and complicated to warrant inclusion in this work, and the reader must refer to one 
of the numerous text-books on Zoology if he wishes to probe more deeply into the subject.

Animals may be classified, commencing with the lowest forms and ascending to the highest; or the reverse method may be adopted. The latter is the system used in this sketch, as the only comprehensive modern work dealing with South African mammals is classified in this way. The following is a more complete list of the SubKingdoms into which the Animal Kingdom has been divided: Vertebrata (backboned animals), Tunicata (seasquirts, \&c.), Mollusca (mussels, suails, \&c.), Molluscoidea (moss-corals and lampshells), Arthropoda (lobsters, crabs, and insects), Vermes (worms), Echinodermata (starfish, sea-urchins, \&c.), Coelenterata (sponges, corals, and jellyfish), and Protozoa (the lowest forms of animal life, including the germs of many diseases).

\section{Vertebrate Animals.}

The Vertebrates, as already stated, constitute the highest group of animal life, and are mainly characterized by a vertebral column or backibone, which consists of a number of bones called vertebra, joined together by ligaments. Through the centre of the backbone runs a canal containing the spinal marrow (a cord of nerve tissue rumning from the brain to the end of the column). On the opposite side of the backbone or spine there is a much larger cavity, formed by the ribs and breastbone, which contains the heart, lungs, liver and intestines, frc.

Vertebrate animals are still further characterized by the possession of not more than four limbs, and by the fact that the jaws are situated one above the other, $\mathrm{Or}^{\circ}$ "upper and lower." 
The Vertebrate Sub-Kingdom is divided into the following five classes:-

(1) Mammalia (mammals, animals which suckle their young).

(2) Aves (birds).

(3) Reptilia (reptiles, snakes, lizards, and turtles).

(4) Amphibia (frogs, newts, and salamanders).

(5) Pisces (fish). 


\section{Order PRIMA'IES. (Apes, Monkeys, and Lemur.s.)}

The form is more or less human-like, with a tendency in the animal to assume an upright position. Body covered with hair. Feet hand-like in shape; as a rule, five digits to each foot-both hands and feet forming grasping organs, the big toe being opposable to the other toes, a feature man has lost. The collar-bone is well developed, and the sockets of the eyes are completely surrounded by a bony ring. The mammæ are thoracic and two in number.

Of the man-like Apes (Simiidæ) South Africa possesses no representative.

\section{Family CERCOPI'THECID无.}

This family includes the Old World Monkeys and Baboons, which are quadrupedal and possess naked patches of hard skin on the buttocks termed "callosities." The number of teeth is the same as in the man-like Apes, viz., 32, but differing from those of the Simiidæ by the two-ridged character of the molars. Dentition: Incisors 2-2, canines 1-1, pre-molars 2-2, and molars 3-3. Tail not prehensile.

Cercopithecus pygerythrus. Vervet Monkey. Blaaniaap. (Also callead the Grey MIonkey and the Natal Monkey by the Colonials.)

Description: Above of a grizzly greenish-grey colourgreyer in some individuals, darker in others. The hairs are ringed alternately with black and white or black 
and yellow, A narrow band across the forehead, chin, cheeks, and underparts, including the insides of the limbs, a dirty white. Face, hands and feet black. 'The hairs at the root of the tail reddish. The scrotum is of a bluish-green colour, hence the vernacular name of "Blaauwaap" given to it by the Dutch South African. Young animals are greener in colour than the adults.

The total length is about $4 \frac{1}{2}$ feet, whereof the tail measures ¿2 feet. I have, however, occasionally seen larger examples. 'Trouessart, "Catalogus Mammalium," recognizes two species of Vervet, the other one being $C$. lalandei, but the matter requires further working up, although my own opinion is that in South Africa there is only one species.

A sub-species, C. p. rufoviridis, is recorded from Portuguese East Africa.

The Vervet is the commonest monkey in South Africa, and is found in all the wooded tracts, ranging from Swellendam in the Western Cape Colony through the Eastern Districts, the Orange River basin, Natal and Zululand, to the Transvaal. I found it common at Vliegepoort, Rustenburg district, and also along the Maputo River in Portuguese South-East Africa. It lives in troops of from three to several dozen individuals, and feeds upon the gum of the Mimosa tree, berries and fruit, including prickly pears, insects, spiders, vegetables, ic., and in cultivated districts (like its larger relative the Baboon) is much given to thieving.

The cry of the Vervet Monkey is a harsh, loud, cackling bark, but it also emits a peculiar, soft rattlelike grunt expressive of pleasure or curiosity, or when it desires to attract attention. When young it malies an amusing and lovable pet, but when old it very often becomes treacherous and cranky, and cannot be relied 
upon. Several hundreds of these animals have passed through my hands at the Pretoria $7 \% o$, and of all the adults there were only two that I could realily trust. They are quarrelsome animals, and it is almost impossible to keep a number of them together in a cage, the stronger fighting continually amongst themselves, and bullying the weaker.

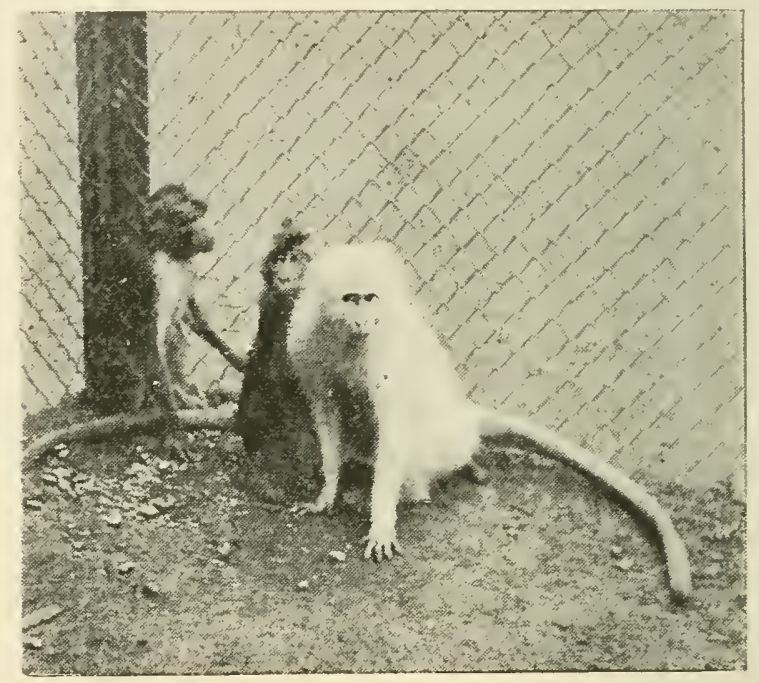

FIG. 1.-Albino Vervet Monkey.

The peculiar fact noted of the young one born in the London Zoo was substantiated in an instance in the National Zoological Gardens, namely, taking both teats of the mother in its mouth at once. The mother lost the hair of the white frontal band on the forehead before the birth of her baby, which, however, had grown out again by the sixth week after the birth of its young one. Neither of these facts appear to be constant, as there is now a young one in the Zoo which often uses only one teat, and its mother has only lost a little of the hair of the frontal band. The first-mentioned little one was born on October 1, 1909, and at the date of its death- 
at the age of ten months-was not even half grown, so that the growth to maturity would probably occupy three to four years. 'The newly-born Vervet is of a much darker and greener shade than the adults, which becomes paler and greyer as the animal gets older. When a fortnight old he was first allowed on the ground, but not beyond arm's length of his doting mother, whose fond and solicitous regard was ludicrous, and even touching. At the age of one month he climbed about the branches of the tree-perches by himself, but was not allowed to go far. The $7 /$ oo possessed several pure albinos of the Vervet (with pink eyes) from the Orange River, presented by Mr. Montague Gadd, of Tafelberg, the first of which after four years in the gardens died of acute dysentery.

Mona albigularis, var. beirensis. Mozambique Montey. Tlozambili Aap.

The colour on the head and shoulders is a dark speckled greenish grey, the cheeks being paler. The region from the back to the tail is of a speckly greenish yellow, the hair being ringed with alternate yellow and black. Below, greyish or dirty white, with the exception of the chin and upper chest, which is pure white. 'The fore limbs are black, the hinder limbs paler (ashy black), the feet are black, and the root of the tail is rufous. Base of tail yellowish rufous, darkening to the final three-quarters, which is quite black. 'There is no white frontal band on the forehead. This animal is about the same size as the Vervet. It is an East African species, and was included by Mr. IV. L. Sclater in the fauna of South Africa on the strength of an example collected at Umtali in Mashonaland, and presented to 
the S.A. Museum by Mr. Morrison. Mr. Claude Grant, of the British Museum, collected a female in the Woodbush in 1905, and says they are common there, but difficult to obtain on account of their wariness. Natives of the Northern Transvaal in my employ, upon seeing an example of the Samango, stated that it was found in the Koutpansberg, but they were evidently confusing it with the present species-a natural enough mistake for an uneducated native to make, and one which many unobservant white men would probably follow. 'The Zoo has had examples from the neighbourhood of Delagoa Bay and Southern Rhodesia.

Mona samango. Samango Monkey. Samango Aap.

Colour of the upper parts a dark grizzled grey, darker' on the head and shoulders. Underparts resembling those of the Vervet-being of a dirty or yellowish white. Face, fore limbs, hands and feet black. Outside of hind limbs dark grey, nearly black on the upper portion of the hips. Ears whitish. The hair of the cheeks long and forming side whiskers. The terminal three-quarters of the tail is black. The Samango further differs from the Vervet monkey in having no white frontal band and no red hair at the root of the tail. It is a slightly larger animal, measuring from 4 to $4 \frac{3}{4}$ feet in total length, the tail alone measuring from 2 to 2 . feet.

This is a much scarcer monkey than the Vervet, and has a much more restricted range, being confined to the thickly wooded portions, from the Pirie Forest near Kingwilliamstown, ranging through Pondoland and Natal to Zululand. Mr. W. L. Sclater states that it is also found in Portuguese East Africa, which I much doubt, this species having been confused with the preceding one. 
The National Koological Gardens has been indebted on more than one occasion to my friend, Mr. Frank Pym, of the Kingwilliamstown Museum, for examples of this pretty monkey. It appears to be nothing like so hardy in captivity as its commoner relation, the Vervet, and is of a more restless disposition, and never seems to wholly overcome its natural shyness. Mr. Pym tells me it is seldom seen far from the forest, although it occasionally makes short trips into the mealie fields after the grain and pumpkin crops. "Its home is undoubtedly in the thickest part of the forest," he writes, "and it is extraordinarily shy and difficult to shoot. 'The males occasionally give vent to a call, which may be described as a quick series of coughing grunts. This can be heard at a long distance, and is surprisingly vociferous for so small an animal. If the vegetation is sufficiently dense, the Samango does not make off when approached, but conceals himself in a wonderful manner, not even its tail showing. I have never heard of its associating with the commoner Vervet. Its food consists of fruits, berries, leaves and insects. One I had in captivity caught and devoured a chicken."

\section{Papio cynocephalus. Yellow Baboon. Ciccle Tiaviaan.}

The colour varies from an ochreous to a brownish yellow. A very old male in the Pretoria $/ \% o o$ is of a greenish tinge much resembling one form of the Chacma. The underside is paler and the whiskers are yellow. It is a much thinner, lankier built animal than the Chacma, with relatively longer limbs and shorter muzzle. It is the East African species, and within our limits occurs in Portuguese South-East Africa. 'The National Zoological Gardens contain two males from the first- 
named territory, one from Barberton ${ }^{1}$ and one from British East Africa. Both the first-named have now been in the gardens since November, 1905, and although tractable animals with anyone they know, are vicious

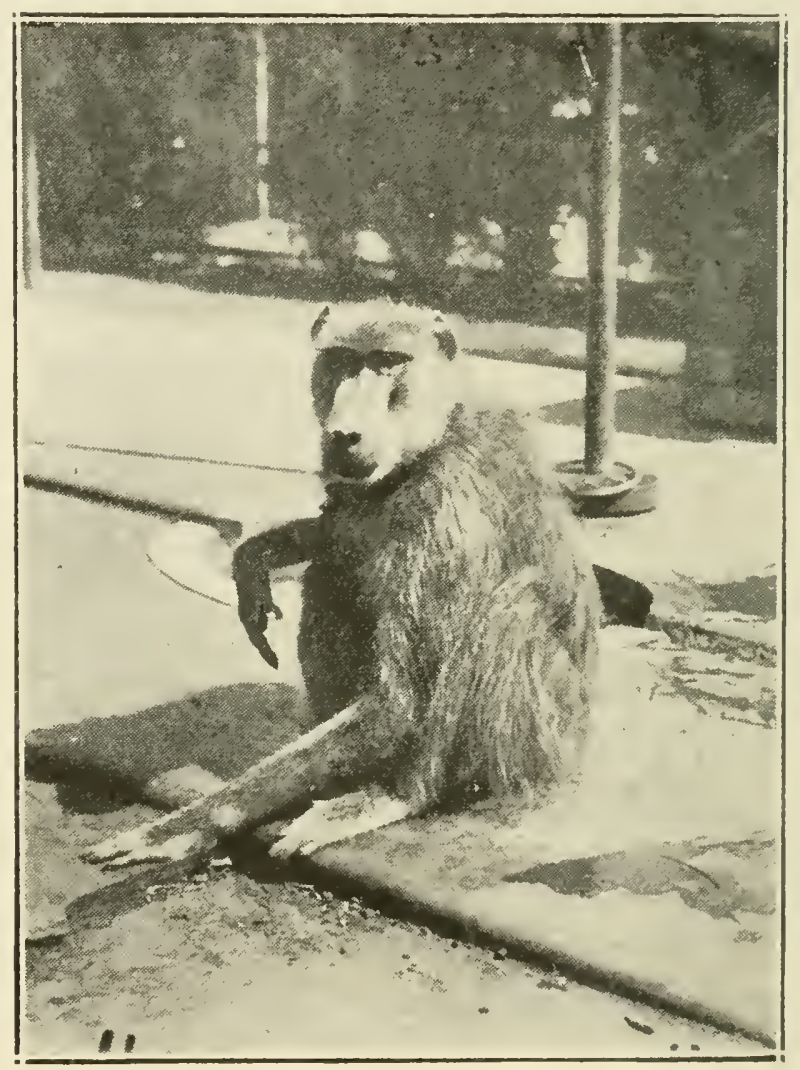

FIG. 2.-Yellow Baboon.

with strangers. The older one of the two once gave us a lot of tronble. He broke loose owing to being teased by some thoughtless visitors to the gardens, and 'bolted' through the grounds, followed by two of the keepers and half-a-dozen natives. He wonld let no one come near him and would show fight upon

1 This record must be an error in the books of the \%oo. 
the approach of anybody. He eventually allowed himself to be caught by his own particular "boy," who had arrived on the scene, and led home like a lamb. When irritated by the public he used to throw stones at them while he was located on the old pole-stand, which was on the natural ground floor, but after the new stand had been built on a concrete floor he resorted to dashing water over his tormentors, and many a man and woman has been justly rewarded for teasing with a sudden and unexpected ducling.

\section{Choiropithecus porcarius. Chacma Baboon. Baviaan.}

This animal is subject to a large amount of variation, and whether two or more sub-species exist is at present not clear. Mr. Pocock has recently separated the Transvaal form from that of the Cape, but so far I can see no reason for so doing. The Chacma is usually of a dark olive-brown colour, darker on the lower half of the limbs - the hands and feet being generally black. Muzzle elongated.

Some individuals are yellower, others greener in tone. The length of the head and body is about 3 feet, tail $1 \frac{1}{2}$ feet. This animal is known to the Boers as the Baviaan, and is pretty evenly distributed all over the sub-continent. The Baboon with its dog-like face and sharp barking howl, is well known to nearly every resident in South Africa. It inhabits rocky billsides and kranzes all over South Africa, being even found on Table Mountain. They go about in groups of various sizes, and are so depredatory in some districts that the farmers organize hunting parties to rid themselves of a few of the brutes. They live on fruit, vegetable matter, insects and spiders, and pillage the farmers' 
mealie crops. They feed as a rule in the early morning and towards dusk. When encamped with a companion on the banks of the Crocodile River in the Hartebeest Poort (District Pretoria) one moonlight night, we could not get to sleep on account of the Baboons, which came swarming over the kranzes about 600 yards from us,

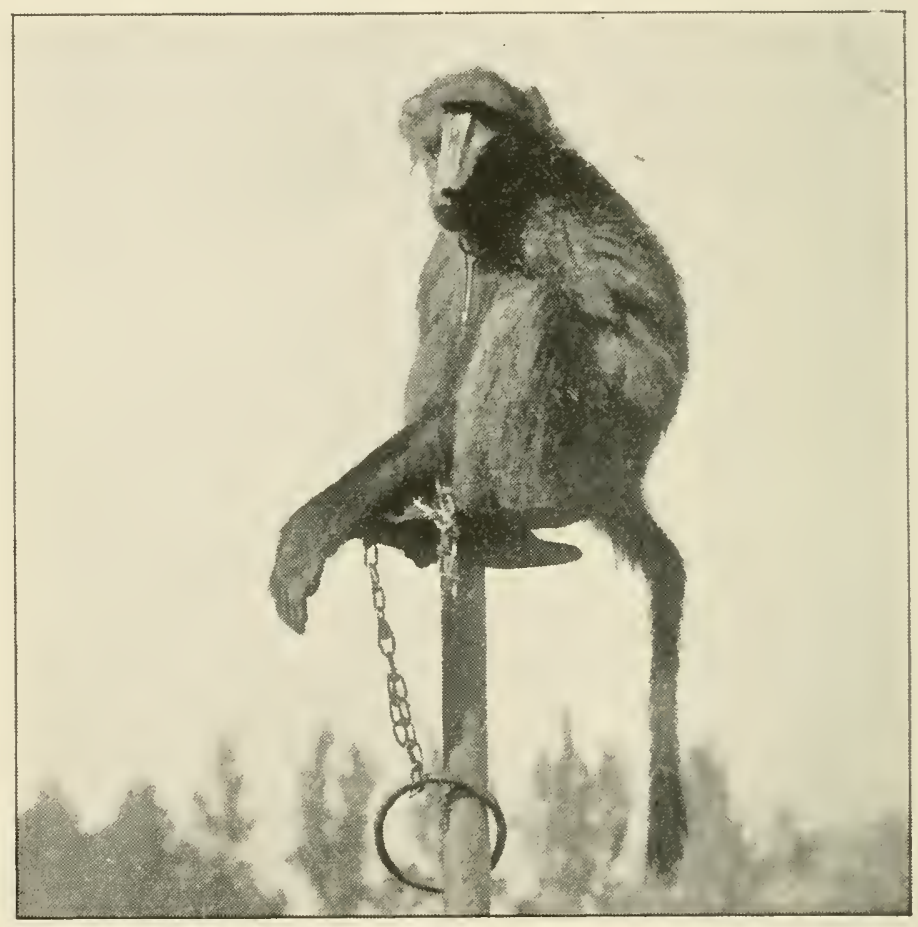

FIG. 3.-Chacma Baboon.

as we lay motionless under the trees. The barks of the adults and the incessant screaming of the young ones was anything but pleasant, and we could watch their every movement, it being a bright moonlight night.

W'hen feeding they are in the habit of throwing out sentinels to warn the troop of impending danger. When young they make pleasant pets, being intelligent and confiding, but old animals can seldom be trusted; they 
are generally a little too ready with their powerful teeth. In the Eastern Province of the Cape the writer has seen large troops of Baboons stealing the green mealie-cobs and pumplins from the lands, and a favourite method of killing them was to set a spring-gun across an opening in the hedge which surrounded the fields. 'They are often very tenacious of life, and old males sometimes take a lot of killing, although Major Hamilton thinks differently. I once saw an old male with five bullet holes in him being dragged along by natives, and he was continually catching at and holding on to tufts of grass, bushes, \&c., until a bullet in his brain put an end to his misery. Another hideous sight I have seen on more than one occasion was the tearing out of the entrails by Baboons wounded in the stomach. They will also stuff the wound with grass.

The Chacma is fairly sagacious, and soon learns to perform various tricks, hence being in constant demand by circuses and menageries. An old male in the Pretoria Zoo was very good at somersaults, but he would not exhibit his skill without payment. I have repeatedly tried to cheat him into imagining I had food in $\mathrm{my}$ pockets for him, but he would take no notice of such make-belief, and refused to 'show off' until the tit-bit was openly shown him.

Another individual we have had for some time has learnt quite a number of tricks, and besides throwing somersaults, he twists or waltzes round to the left, as well as to the right, stands up, gives the military salute, shakes hands, puts on a hat, and fetches a stone or any other handy article pointed out to him. However, like the first-mentioned animal, he refuses to perform without being shown a reward in the way of something tasty, or he has to be threatened with a whip or stick. 
Choiropithecus rhodesiæ, Haagner. Rhodesian Baboon. Rihorlesies Baviaan.

Description.-Upper parts of a grizzly olive-yellowish colour, much darlier on the crown and along the spine, where the hairs are long and tipped with black, forming a mantle. These long hairs range from 5 to 12 inches in length. Legs, feet and tail coloured like the sides, the individual hairs being ringed with black and yellow, the tips being pale yellow and the bases grey. Below pale greyish white, especially the chin, lower cheeks and throat, insides of the legs, belly and a patch behind each armpit; chest and limbs speckly. Muzzle considerably lengthened and pointed, more resembling that of the Chacma, and not short and rounded like that of the Yellow Baboon. Length of the head and body 3 feet 6 inches to 3 feet 9 inches. Length of snout from tip of nose to frontal ridge between eyes 6 inches. Length of forearm from tip of middle finger to end of elbow $16 \frac{1}{2}$ inches. Length of hand from tip of middle finger to metacarpal joint 6 inches. Length of top canines $2 \frac{1}{8}$ inches. Ears rather small and almost hidden by the hair of the upper cheek. Tail long ( 2 feet 4 inches).

Remarks.-This animal is bigger and heavier in build than any Chacma or Yellow Baboon we have ever possessed. In coloration the Rhodesian Baboon somewhat resembles the Iellow Baboon, but is darker and in build is much more like the Chacma. It lacks the darker tip to the tail often found with the latter animal, and has not black hands and feet. 'The cry of this species also differs somewhat from that of the Chacma, being shorter and more cough-like. 'This example was received in February, 1913, along with two others from Central Rhodesia, and noticing well-marked differences from young Chacinas, I kept one to see whether these 


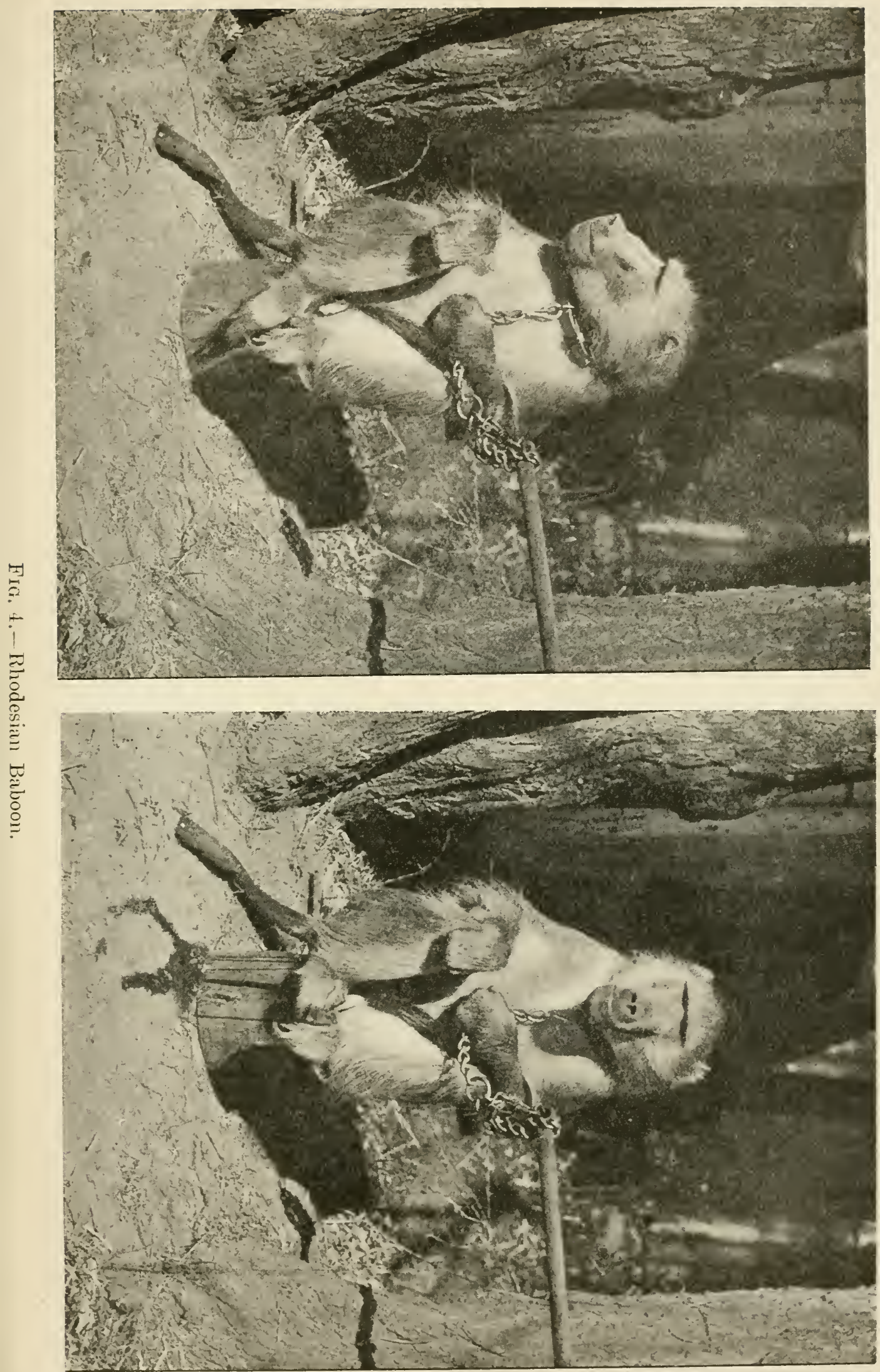


characters would persist in the adult animal. The example is now 6 years old and, I should say, fully adult; I am describing it as well as I can from a living specimen. I have since received a skin and skull from a friend at Marandellas 11 Mashonaland, who told me, before he saw our example, that their Baboon was different from the Chacma, and that it is common in that neighbourhood, but not easy to obtain on account of its wariness and the hilly nature of the regions it frequents. The receipt of the skin and skull confirms my opinion as to the novelty of the species. 'The skull appears to be intermediate in general characters between the Chacma and Yellow Baboons, and can be described as follows :-

Skull of Rhodcsian Baboon.--Parietals not so rounded or high as in porcarius, more like those of cynocephalus; sagittal crest more developed, although in very old Chacmas this is more advanced than that of the example on the accompanying plates; frontals wider; supraorbital ridge well developed; squamosal not so deeply dented as that of the Chacma. Nasals long, and broader than those of the Chacma, the nasal opening or orifice being much wider and more open than that of the Chacma, resembling in this detail more the skull of the Yellow Baboon; maxillæ higher, with the ridges more pronounced than those of the Chacma Baboon.

Measurements (in millimetres).-Total length of skull, 217 ; zygomatic width, 120; occipito-nasal length, 171; intertemporal width, 61 ; medium length of nasals, 77 ; length of upper canine, 40 (tips badly worn); length of upper molar series, 61 ; lower molar series, 82 ; length of mandible, 162.

As will be seen from the above, the skull-like the rest of the animal-partakes of the characters of both the Chacma and Yellow Raboons. 
With regard to geographical range, this is still in doubt. As I have recently received the skin of a fine male shot on the Kafue Flats in Northern Rhodesia by Dr. A. A. Schoch, the range of the species seems fairly wide.

\section{Family LEMURIDE.}

In the more nodern classification the Lemurs are relegated to a separate order, the Prosimix (Lemuroidea). They are usually nocturnal animals, covered with fur.

Their home is in the Island of Madagascar, but several species are found in South Africa. These are characterized by their large, rounded, and nearly naked ears. which are capable of being folded at will. The eyes are large, and the tail is thick and bushy. The fingers and toes are supplied with flat nails, with the exception of the second toe of the hind limb, which has a distinct claw.

Otolemur crassicaudatus. Thick-tailed Lemur. Bosch Aap.

To the Natal Colonist it is known as the "Bushbaby," a name also applied in the Transvaal to the Night Ape or Moholi Lemur. The Zulus call it the "Sukwe."

The colour is a yellowish to slaty grey, the hair being soft and thick. The ears, hands and feet are nearly black. The chin and underparts are yellowish-white. The tail, which is thick and bushy, is about a foot long. The total length of the head and body is only 14 inches. Teeth, 36 in number.

This animal is found in Natal, Zululand, and the more thickly wooded portions of the Eastern Transvaal. The National Zoological Gardens possesses an example from near Lydenburg. This species was also procured in the Gorongoza Forest of Portuguese South-East Africa by 
Mr. C. H. B. Grant, and I shot one near Bela Vista, in the Maputa District of the same territory in August, 1918, where it seemed to be fairly common.

Little is known of the habits of this strange creature. Mr. C. H. B. Grant, who collected for the Rudd Exploration of South Africa, obtained examples at Eshowe and Ngoye Forest in Zululand, and says: "It is almost exclusively an arboreal animal. It sleeps during the day in some hollow tree, waking up at sundown, at which time and throughout the night its peculiar cry can be heard." The individuals in the Pretoria Zoo are not very regular in their habits, appearing one afternoon just before or after sundown, and perhaps on the following day not till dark. It feeds upon insects, fruit and gum. When irritated it makes a harsh, rattling cry somewhat resembling that of the Vervet Monkey, but not half so loud: I believe in its wild state the usual call is a plaintive cry not unlike that of a baby, hence its vernacular name of "Bushbaby." A closely allied species (O.garnetti) is supposed to exist, its geographical range overlapping to a certain extent that of the preceding animal.

Galago moholi. Moholi Lemur. Nachtaapje.

This is the Night Ape or Bushbaby of the Colonists, and Nachtaapje or Boschaapje of the Boers.

The colour is a slaty-grey or mouse-grey above and a yellowish-white below. Chin and throat pure white. There is a white stripe down the nose and a dark ring round each eye. The tail is long, measuring about eight or nine inches, and has a bushy tip. The length of the head and body is about seven inches. The eyes are large and soft, and of a bright pale to hazel-brown 
colour. One example in the Pretoria $/ / 00$, caught in the Pretoria Bushveld district, has the terminal 2 inches of the tail of a pure white. 'This little animal ranges all over the wooded portions of the Transval, but has so far not been found in Natal or the Cape Colony. It is replaced in Rhodesia by the closely allied G. mossambicus, and in Portuguese South-East Africa by G. granti.

The Moholi Lemur is very common in the Pretoria and Rustenburg Bushveld, whence the Zoo has had many examples. It feeds upon the gum of the mimosa tree, berries and fruit, as well as insects and spiders. It is nocturnal in habit, lying asleep during the day and going forth to feed at dusk.

The Night Ape is a wonderfully agile little creature, and can leap remarkable distances for so small an animal. It makes an amusing and often lovable little pet.

There is a female at present in the Pretoria Zoo suckling two young ones, which was captured with her young. Another female gave birth in October, while in captivity, to two young ones-so that two would appear to be the usual number. They cling to the mother like the young of the ordinary Ringtail Lemur and South American Marmosets, and ride on her back or hang underneath her as opportunity offers.

Galago mossambicus. Peter's Hoholi Lemur. Peter's Nachtaapje.

This animal is mainly distinguished from the preceding species by its smaller size and relatively longer tail. It was obtained by Mr. C. H. B. Grant at Tette, on the rambesi, and recorded by Mr. E. C. Chubb from Bulawayo and the Mansamnyama Rivers (in the Bulawayo Nuseum). 
Galago granti. Grant's Moholi Lenur. Grant's Nachtaapje.

This species was described by Thomas and Wroughton in the Proceedings of the Zoological Society of London as follows :-

"Above drabbish brown; below creamy buff. A light nose-line and black rings round the eyes, as in $G$. moholi. Outer side of fore limbs light drab, paling to white on the hands. Hind limbs dull creamy buff. Tail long and very bushy, the hairs being nearly twice as long as those of moholi, the basal 3-.) being drab-brown like the body, and the terminal portion darkening to blackish brown. Muzzle longer than that of G. moholi. Length of head and body $158 \mathrm{~mm}$., tail $237 \mathrm{~mm}$. ; habitat, Coguno and Inhambane, Gorongoza Forest, Portuguese SouthEast Africa (C. H. B. Grant). Common, inhabiting the forests; nocturnal, sleeping during the day in hollow trees." 


\section{Order CHIROP'TERA.}

The Bats, which animals constitute the above order, are mammals with the forelimbs greatly lengthened and supporting a membrane which is modified for flight.

The bones of the arm and the four fingers are elongated; the thumb or pollux is short and bears a claw, and is not connected with the flying membrane or patagium, which is united to the fingers, forearm, sides of the body, and tail. The teeth never number more than 38. The skeleton is very light.

The name "Chiroptera" means "handwinged," from the fact that the apparatus for flight is furnished mainly by the fore limbs.

Bats vary considerably in their powers of flight-as much, perhaps, as flying birds, and may be seen on the wing during the evening and night, making sudden dashes after insects. They possess a curious "second sense," which may be termed "tactile," although it appears to be something more ; they have the power of avoiding objects without actually coming in contact with them or being able to see them, which was once. sufficiently proved by cruelly blinding the poor creatures and turning them out into a room across which a number of threads had been stretched. Bats are helpless on a Hat surface, and can then only crawl very slowly.

They usually suspend themselves by the hind legs head downwards from the rafters in ceilings, from ledges of rock or branches of trees, and remain like that during the day-time, sallying forth at night in quest of food.

We found the limestone caves on the Hennops River, 
in the Pretoria district, full of bats-in fact, when we penetrated into the intensely dark interior we disturbed them by the score, and they left their perches in clouds as we advanced, and we could feel the "swish" of their wings as they continually dashed past us, repeatedly putting out our candles.

The species obtained included the "Horseshoe Bat" (Rhinolophus augur), Petalia capensis, Mineopterus natalensis, and Nyctinomus agyptiacus.

The large majority of bats feed upon insects, but some live on fruit, while others-the Vampires of South America-are blood-sucker's.

South African Bats are of two sub-orders, the Megachiroptera (containing the large fruit bats) and the Micro-chiroptera (containing the smaller Serotine, Horseshoe and Nose-leaf Bats, which are mostly insect eating).

\section{Family P'TEROPODIDE.}

The members of this family constitute the largest of the Chiroptera, and feed upon fruit.

The head is not short and slimpy, as in the other families, but is long and dog-like. The ears are small. There are two genera, distinguished mainly by the tail, that of Epomophorus being free from the interfemoral membrane, while that of Rousettus is attached at its base to this membrane. Both genera contain two species found in South Africa.

\section{Epauletted Fruit Bat. Epomophorns wahlbergi.}

Lips thick, having a swollen appearance. General colour, above mouse-grey, paler below. There are tufts of white hair on the inner margin of the ear, and also on the shoulders, where the glands are situated. The 
tail is very short, almost rudimentary, and concealed in the fur. The length of the head and body is $6 \frac{1}{2}$ inches (male), $5 \frac{1}{2}$ inches (female). This bat ranges from the eastern portion of the Cape Province through Natal and Zululand to the Equator. It was procured at Ngoye Forest in Zululand by C. H. B. Grant, who says that they do not fly until two hours after dusk, and that during winter they feed upon the berries of the syringa tree. Their usual food is figs, peaches, and any of the softer wild fruits.

Epomophorus crypturus is a smaller species, closely resembling the foregoing in most respects.

\section{Common Fruit Bat. Rousettus collaris.}

Lips not swollen. The general colour above is brown ; paler below. 'The hair of the neck is long, and in the male of a yellow colour. There are no white tufts, as in the preceding species. Length of the head and body $5 \frac{1}{2}$ inches, tail $\frac{1}{2}$ inch. This bat is found throughout South Africa, and is common in Capetown and at Knysna, at which latter place Mr. C. H. B. Grant found it plentiful in a cave on the "heads."

It devours ripe fruit, and, according to Mr. WV. L. Sclater, is especially fond of loquats.

Mr. Layard asserts that it will devour insects when no fruit is available.

\section{Yellow Fruit Bat. Rousettus stramineus.}

This species can be easily distinguished from the foregoing by its pale yellow colour (almost lemon yellow) It ranges pretty well all over the African continent, but South African records are few. An example in the Pretoria Zoo, from Durban, lived almost exclusively 
upon bananas, but would also eat other soft fruits, such as apricots, \&c. It would crawl down from its perch or branch (where it lay hidden all day) as soon as its food was put in the cage at about 4.30 p.m., and devour as many as three and four bananas at a time.

\section{Family RHINOLOPHIDA:}

This family contains bats of small size with peculiar membrane-like expansions on the muzzle, the so-called "nose-leaf" surrounding the nostrils, whence the vernacular names of "Horseshoe" and "Leaf-nosed" Bats. Ears large and without au "inner-ear" or "tragus." First finger without a phalanx. Tail distinct.

There are two genera of these insect-eating bats in South Africa: (a) Rhinolophus, with a complicated noseleaf and the base of the lobe of the ear expanded; teeth, 32. (b) Hipposiderus, in which the nose-leaf has the upper and hinder portions not terminating in a point; no expanded margin of the ear ; teeth, 30.

\section{Genus RHINOLOPHUS.}

This genus contained in 1914 six South African species: Rhinolophus ferrum-equinum, $R$. capensis, $R$. hildebrandi, $R$. augur, $R$. darlingi, and $R$. denti.

The first-mentioned is the common European Horseshoe Bat, characterized by the ears being very nointed and attenuated at the tips, the colour above being of $a$ reddish-brown, and below of a pale yellow. Length of head and body 3 inches, forearm $2 \frac{1}{10}$ inches.

The Cape Horseshoe Bat (R. capensis) is smaller than the European species (head and body $2 \frac{3}{3}$ inches), and is of a paler red.

The Augur Bat (R. augur) seems to be the common bat of the Transvaal and Bechuanaland. It is recorded 
from Barberton, Woodbush, and Wakkerstroom by Mr. C. H. B. Grant, while Mr. R. B. Woosnam wrote that he found some hundreds on the rocks in a shaft of an old gold mine near Kuruman, and that they are common, but only found in caves and similar localities.

I collected some in a deep underground cave at Hennops River, in the Pretoria district, where this species and several others were very common, and their guano formed a layer on the floor from 18 inches to 3 feet thicls.

\section{Genus HIPPOSIDERUS.}

'This genus contains about four species, the best known of which are $H$. caffra and $H$. commersoni. The former is grey above and paler below, and the latter a reddish brown above, grey on the sides, and whitish below.

The former is the larger, measuring, head and body, nearly $4 \frac{1}{2}$ inches, while the latter is only a little more than $2 \frac{1}{2}$ inches long.

\section{Family NYCTERID A.}

Nostrils surrounded by a nose-leaf, or placed sometimes at the end of a long deep groove. Ears united and very large, with well-developed tragi.

The genus Nycteris (also called Petalia) contains several species commonly known as "slit-faced" bats. 'The Cape Slit-faced Bat (N.capensis) has the ears longer' than the head, and is grey-brown above and whitish below. Length of head and body $2 \frac{3}{5}$ inches, tail 2 inches. It usually inhabits lofts and outhouses.

\section{Family VESPERTILIONID E.}

The nostrils are simple openings at the extremity of the smout. Ears moderate and usually separate, with a stiff process arising from inside the conch-the tragus. 
The tail is long and attached in the membrane, with only the tip projecting.

This is a large family of insectivorous bats, containing some half-score South African species, for a complete account of which the reader must refer to the recent papers of Mr. Knud Anderson and other mammalogists.

The Serotine Bats (Vespertilio) and the Long-winged Bats (Miniopterus) are perhaps the best known of the genera. Several of the species were obtained by us in the caves of the Pretoria district.

The best known species are (a) the Cape Serotine Bat (Vespertilio capensis), which has the tail enclosed in the membrane, the ears of medium size and placed wide apart. Colonr light brown. Width, with outstretched wings, $8 \frac{3}{4}$ inches.

(b) The Long-winged Bat (Miniopterus natalensis) resembles the preceding species, but is considerably larger. Ears short and broader than the head. Width, with outstretched wings, about one foot.

\section{Family ENBALLONURID}

The nostrils are simple, and situated at the end of the muzzle, which is truncated. Ears large and generally united. Tail partly free. There are two genera in South Africa, Taphozous and Nyctinomus.

Of the latter there are several common species, of which perhaps the most abundant is the Long-tailed Bat (Nyctinomus agyptiacus); it has a thick tail, free from the membrane for an inch or so. The ears are broad and large, while the upper lip is wrinkled. Colour brown. Length $22_{5}^{4}$ inches. The Brown Wrinkle-lipped Bat was also obtained by us in the caves at Hennops River, Pretoria district. Peter's Wrinkle-lipped Bat (N. limbatus) is dark brown above, with the throat and abdomen white. Length of head and body, $2 \frac{1}{4}$ inches. 


\section{Order INSECTIVORA.}

This is a group of small, chiefly insect-eating animals, often differing very materially from one another in external appearance. The majority are characterized, however, by the possession of a pointed snout (on the upper lip) projecting beyond the lower jaw. Their molar teeth are provided with projections, called cusps, and their canines are weak and small. The feet are usually provided with five toes furnished with claws. The teeth number 40 to 42 .

\section{Family MACROSCELID E.}

Molar teeth broad, with the cusps forming a W shape. The muzzle is long and tapering, with the nostrils situated at the end of the snout. The fore limbs are short and the hind legs are much longer, the tarsus being shorter than the lower portion of the leg (or metatarsus), the animal resting on this after the manner of a kangaroo. The tail is long and almost devoid of hair.

In South Africa we have two genera of these strange long-snouted little mammals, the first being Macroscelides. Trouessart recognized four South African species, and W. L. Sclater in his "Mammals: Fauna of South Africa" mentions five; since then several species and sub-species have been added by Oldfield Thomas and his colleagues of the British Museum from material collected for the Rudd Survey of South Africa. As it would be idle to attempt a complete account of these little animals in a work of this nature, it must suftice if we mention the 
commoner and better known species. These are the Common or Cape Elephant Shrew (MI. proboscideus) and the Rock Elephant Shrew (M. rupestris).

'The former inhabits the plains or flats of the Cape Colony-especially lightly wooded tracts-the latter, rocky ridges or rocky patches or outcrops near water courses. It ranges from the Northern Cape Colony to the Transvaal. We have collected examples of the latter species at Orange Grove, near Johannesburg, and along the stony ridges of Pretoria. These belong to a subspecies named after Dr. Lyster Jameson, one time of the Transvaal University College.

Both these animals are of a light brown colour, tending to a reddish tinge in some individuals. Below the colour is white, the latter gradually merging into the brown of the upper surface. The Rock Elephant Shrew is a little larger than the Cape species, measuring from 5 to 6 inches to the latter's $4 \frac{3}{4}$ inches, and has reddish patches behind the ears, a characteristic wanting in the other species.

The Cape Elephant Shrew lives in burrows in the earth, while the Rock species inhabits the craclis between the rocks, or forms cavities and runs under overhauging rocks. They both live upon insects of various kinds, grasshoppers and beetles probably forming the bulk of the fare. The mode of progression is kangaroo-like, a slow ungainly walk when the animal is at its leisure, or long rapid jumps on its hind legs when hurried or disturbed.

The second genus, Petrodromus, has so far only been recorded within our limits from Inhambane, in Portuguese East Africa 
Family ERINACEIDA.

This is a small family of little insectivorous and plantigrade animals with a small brain case, and possessingwith the exception of the single genus Gymnura from Malaysia-a projecting coat of short, strong and sharp spines. The claws are of simple structure, and the tail is short.

There is only one other genus-Erinaceus-inhabiting the Palrarctic, Oriental, and Ethiopean regions. In the latter region six species are supposed to exist, only one of which is found in South Africa.

Erinaceus frontalis, L. South African Hedgehog. Krimp Ijzervarkie or Ijgeltje.

The upper portion of the body is covered with sharp spines about 3 inch long; these are white, with a subterminal black or dark brown band and a paler tip. Head dark brown or blackish, with a white band across the face. Below coated with coarse hair, and of a mottled or grizzled grey-brown or white and brown colour. Five toes to both fore and hind feet, all of which are furnished with light claws. Length of head and body from 6 inches to $7 \frac{1}{2}$ inches ; tail, $\frac{1}{2}$ inch.

This little animal is said to be rare in Natal and uncommon in the Karroo and south of the Orange River, but I have found it common enough around Brandfort, in the Orange Free State ; at Modderfontein, near Johannesburg; and in the neighbourhood of Pretoria, where it may be found amongst the plantations and scrub on the ridges and in the valleys. It feeds upon insects, chiefly grasshoppers and beetles, the larve of various insects. slugs, snails, worms, lizards, \&c. It is amusing to listen 
to the-in comparison to its size-loud sniffs which this little creature emits when searching for its food. It is mainly nocturnal in habit, becoming active at sundown, and lying hidden amongst the undergrowth of a thick bush during the day-time.

It rolls itself into a ball with great rapidity as soon as danger threatens, and is then not a pleasant object to handle. It is then immune to the attacks of dogs and the smaller wild carnivorous animals. In the Zoo it does not seem to thrive, and although the artificial diet of minced meat and hard-boiled eggs is supplemented as often as possible with meal-worms and other insect food it does not live very long in captivity, at least not in comparison with the majority of animals. Two years is the longest we have been able to keep one alive. A female was brought into the Zoo on one occasion with four young ones, which she succeeded in successfully rearing. On another occasion a female was brought in with seven young ones, but I think this number is exceptional.

Family SORICIDE.

This family is a fairly large one, containing the true shrews. These are small animals of rat-like or mouselike form, with a long and pointed muzzle (snout-like), the sides of which are swollen by the roots of the bristly whiskers. 'The dentition is variable, but there are aiways three molars, and in the lower jaw six teeth on either side.

Eyes suall and tail long and tapering. These littie animals have, as a rule, a peculiar musliy odour, which comes from a fluid which is secreted in glands opening near the bases of the fore limbs.

There are two sub-families, Soricince and Crocidurina; 
only representatives of the latter are found in South Africa.

\section{Genus CROCIDURA.}

The members of this genus are usually of small size, with pointed snout-like muzzles possessing swollen sides, which are caused by the roots of the "whiskers." The tail is tapering, and besides the clothing of short bristlelike hair, it possesses a number of scattered long whitish hairs. The mamme are six in number, and are inguinal. There is no canine tooth in the lower jaw, and only one premolar, the total number of teeth varying from 28 to 30. The Shrew Mice feed upon insects and their larvæ and are thus true friends of the agricultmist.

Trouessart, in his "Catalogus Mammalium," enumerates seven species, while W. L. Sclater, in his "Mammals," includes nine. A number of species have been described since then, however, principally by Oldfield Thomas, of the British Museum, and his colleagues, from material collected for the Rudd Zoological Survey of South Africa. As they are difficult little animals to determine, being all of some shade of grey-light, medium, slate and dark-it would serve no good purpose to go into detail in a book of this nature. I will merely mention one of the species with which I have had a good deal of personal experience, and whose breeding habits I have been fortunate enough to observe.

Crocidura yarilla. Dwarf Shrew. Dwerg Langsnoet Minis.

This is one of the smallest of the Shrews, if not the smallest, in South Africa. It is nearly mouse-grey in colour, paler below, with the snout and pedal extremities white. Length of head and body about $1 \frac{3}{1}$ inches. Tail nearly $1 \frac{1}{2}$ inches. 
I found this little Shrew fairly plentiful at Modderfontein Dynamite Factory, near Johannesburg, where it inhabited the disused hollow antheaps on the veld,

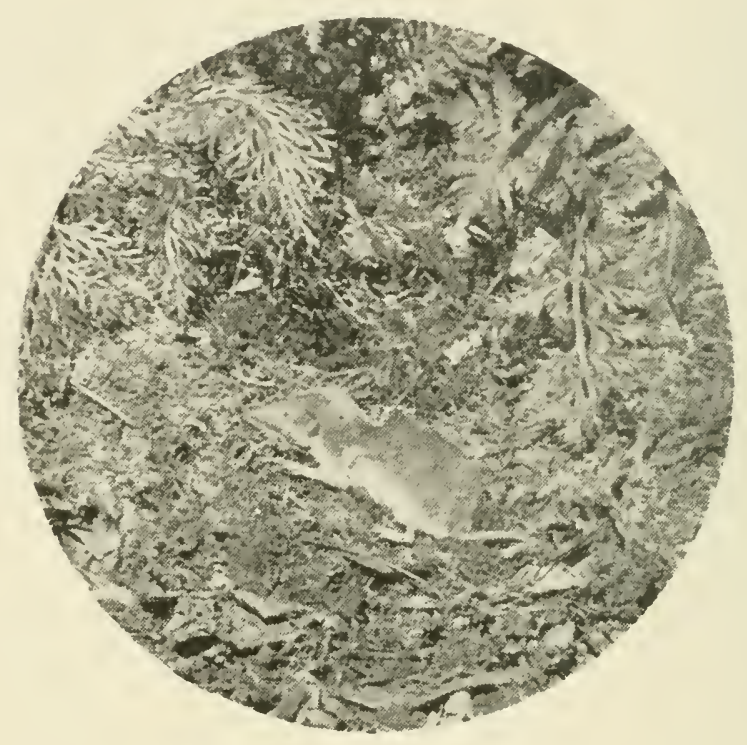

FIG. 5.-Grey Shrew (Mysorex varius, Smuts).

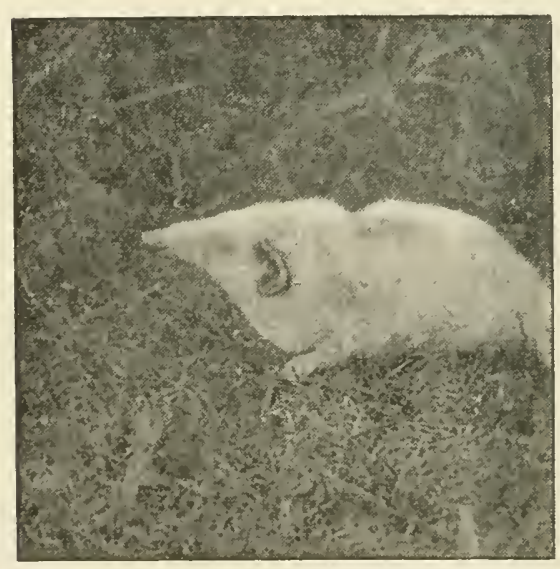

Fig. 6.-Albino Shrew.

constructing as far into the centre of the mound as possible a round nest of grass, where it gave birth to from three to four blind and naked young ones. These little 
creatures were, however, unusually active, and when exposed to the light would wriggle and crawl about in an energetic endeavour to hide themselves.

I have tried to keep this little Shrew in the Zoological Gardens, as well as one other species (Crocidura silacea), but with not much success. The large Shrew (C. flavescens) is of a light reddish brown above, with long, soft fur, and whitish below. Length of head and body nearly 4 inches, tail 2 inches.

The other genus (Myosorex) resembles Crocidura to a large extent, differing only in certain anatomical characters. It contains only a few species, the best known perhaps being the Grey Shrew or Skearer Muis (Myosorex varius), which has a small pencil of hairs at tip of the tail, and of which we append an illustration. This little animal measures about $3 \frac{1}{3}$ inches long with the tail another $1 \frac{3}{4}$ inches, and is brown above, finely speckled with grey.

\section{Family CHRYSOCHLORIDE.}

This family contains the beautiful Golden Moles of South Africa, which are included in the two genera, Chrysochloris and Amblyosomus, and are characterized by the iridescent colours of the fur, which change in different lights. They are mole-like animals, differing, however, from the true moles in certain well-marlied anatomical characters, such as the structure of the manubrium and clavicles, and in that of the hand, which bears but one exaggerated and leugthened claw for digging, whereas that of the true moles bears five strongly developed digging claws. They have very small eyes, which are nearly concealed by the slin, and ears devoid of conches, opening by a simple aperture almost 
hidden by the fur. An extermal tail is absent. The family is confined to Africa, south of the Sahara.

The genera are differentiated by the possession of 40 teeth in Chrysochloris and 36 in Amblyosomus, and the

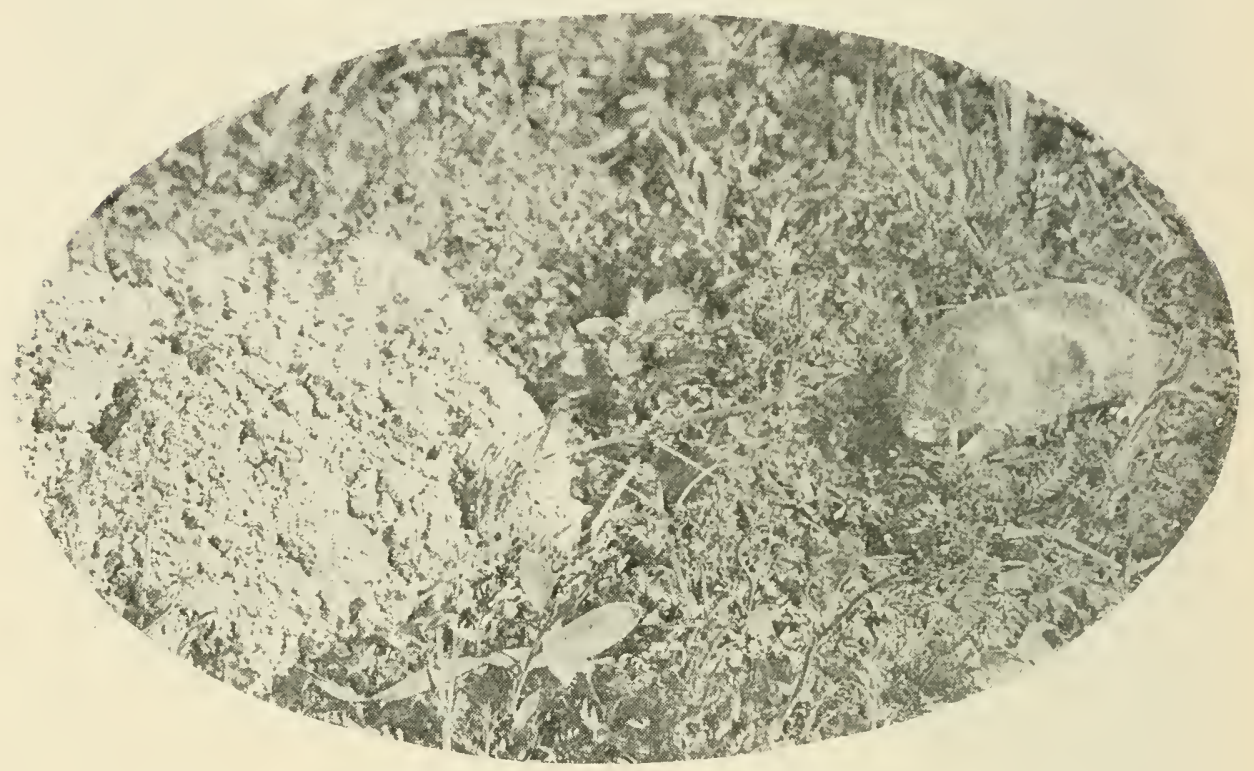

Fig. 7.-Golden MIole at carthmound.

former by a swelling in the temporal fossa, of which the latter has no trace. They live in underground burrows or run close to the surface of the earth, and feed upon worms, grubs, and the larvæ of insects. The commonest species are Chrysochloris aurea, the Cape Golden Mole, and $C$. hottentota, the lied Golden Mole. 


\section{Order CARNIVORA.}

This is a large and varied group of chiefly flesh-eating animals, and include, under the more modern classification now in vogue, only the terrestrial forms (Fissipedia).

The feet possess four or five toes, usually provided with sharp claws. The clavicles, or collar bones, are absent, or when present are small or reduced. The incisor teeth are small and sharp, three pairs in both upper and lower jaw; while the canines are large and projecting. The cheek teeth have cutting edges; the first lower molar and the last upper premolar are modified to form the so-called carnassial teeth.

Condyle of lower jaw transversely elongated, and fitted into a transverse groove on the base of the skull, which limits the movement of the jaw to only an up-and-down action.

Living Carnivores are divided into three sections, the Eluroidea (Cats, Civets, Hyænas, $3 c$. ), the Cynoidea (comprising the Dogs, Wolves, \&c., Canida), and the Arctoidea (Bears, Raccoons and Badgers).

\section{Family NUSTELIDE.}

The Weasels, Badgers and Otters form a group of long-bodied animals distinguished by the absence of an alisphenoid canal to the skull, and by the number of the molar teeth, which are either one above and two below, on each side, or one above and one below. Dentition usually: Incisors $3 / 3$, canines $1 / 1$, premolars $4 / 4$, molars 1/2. Auditory bulla dilated. 


\section{Genus MELLIYORA.}

Body thickset; limbs and tail short. Soles of hind feet naked to the heel. Claws porverful.

Mellivora ratel. The Ratel. Honing Das.

The Honey-badger, as it is sometimes called, is greyish-brown above, some individuals being greyer than others. Below black with a pure white line on the side of the body sharply dividing the grey from the black. Total length about $2 \frac{3}{4}$ feet. Tail about 9 inches. It is found all over South Africa, although seldom seen, owing to its nocturnal habits. It lives in caves, in hollows, or cavities amongst roclss, or in a hollow tree. It eats almost anything from a snake to a fowl, and is inordinately fond of honey. It is a somewhat fierce little animal, and will vigorously defend itself agairst the attack of dogs. Its powerful jaws and persistent nature make it no mean enemy when wounded.

The Zoo has not possessed many of these animals. We had a fierce old male from the Sabi Game Reserves, which lived in the gardens for more than a year, notwithstanding a bad leg injured by the effects of the gintrap which deprived it of its freedom. In 1913, Mr. C. Jones, of Nylstroom, sent us a young one, which is an amusing and tame little animal. He is wonderfully insistent, and on one occasion kept on clawing at a brass padlock, which was an old one, until it dropped open, whereupon the little brute pushed open the door of its cage and climbed on to the roof, where it was found perambulating about, uttering its plaintive little whining call. Two fine adult specimens, captured in the Rustenburg district, were added to the collection in October, 1916. One individual, presented by Mr. Fitzsimons of the Port 
Elizabeth Museum, was of an extremely destructive nature, gnawing his way out of several cages, and on one occasion killing a number of white rats, guinea-pigs and rabbits, but eating none.

\section{Genus ZORILLA.}

Zorilla striata (Ictonyx capensis). Cape Polecat. Stink ILuishond.

This animal is rather slender in form, with a long and somewhat bushy tail. It is black in colour, with four longitudinal white stripes from the back of the head to the root of the tail. There is a white spot on the forehead, and one on each cheek. Length of head and body about 15 inches; tail 12 inches.

The Muishond is fairly common all over South Africa and is nocturnal in habits, spending its time during the day in holes, clefts amongst rocks, \&c., and feeding at dusk and during the night upon birds and small mammals, such as rats and mice, lizards and frogs ; it is also fond of stealing eggs and poultry from the farmyard. It has a habit of emitting a disagreeable odour from the anal glands when in any way disturbed, hence its inelegant but appropriate Boer cognomen.

I have often heard it said that dogs will not attack the Polecat, but such is not strictly the truth. Many dogs, especially sporting dogs, will not do so; but I have known terriers-and on one occasion a pointer-make short work of one of these animals. The dog is, however, not fit for human company for a day or two after this, on account of the clinging nature of the odour. Tame examples when undisturbed show no signs of this smell, and I have had several of them as pets. They were tame and harmless little animals, following me 
about like a dog. They thrive well in captivity, living on raw meat, dead birds, mice and rats.

\section{Genus POECILOGALE.}

Body very long and slender, and the legs short. The teeth number from 28 to 30 .

Poecilogale albinucha. Snake Weasel. Slang IInishond.

This little creature much resembles the Stink Muishond in coloration, differing from this animal, however, in that the whole of the top of the head (or crown) is white. Sometimes this may have a greyish or yellowish tinge. It is also a much smaller and lighter animal, measuring only about a foot in length, with a tail of 6 or 7 inches. It ranges from the Eastern Cape Colony northwards to East Africa. The National Zoo has so far only received examples from Tingwilliamstown, which have been kindly sent us from time to time by Mr. F. A. O. Pym, of the local museum. It is of a retiring nature, lying up in a lair or burrow during the day. Its food consists of small mammals, birds, insects, \&c.

This, to me, is one of the most fascinating of the smaller mammals, as, apart from its peculiar shape and striking coloration, it is exceedingly plucky. We have not been able to keep them in captivity for any length of time, excepting the last pair, received by us in 1913 ; these we turned out into a small cage made of wirenetting and having a sandy floor. As soon as the door of the cage was opened the male would approach in a defiant manner, his back arched and his hair fairly bristling with rage. These two animals lived well in captivity upon chopped raw meat, hard boiled egg, and 
bread and mills, with an occasional small rat, mouse or bird by way of a change. When in slow progression over the ground, the Snake Weasel reminds one forcibly of a caterpillar, the back being arched or humped up in a similar manner to that affected by this insect.

\section{Genus LUTRA.}

Head rounded and ears small. 'Toes of hind feet webbed; soles of hind feet naked. Animals of aquatic habit. Otters are found all over the world, except in Australia. In Africa two species occur, both of which are found in the southern half of the continent.

Lutra capensis. Cape Otter. Kaapsche Otter.

This is the larger of the two species, and is by far the commoner. We have met with it in the Uitenhage, Albany, Queenstown and Aliwal North divisions of Cape Colony; at Brandfort, O.F.S.; and at Modderfontein, Irene and Pretoria, Transvaal. It measures from 30 to 36 inches in length, with the tail another 16 to 22 inches.

It is of a dark brown colour, with the tip of the nose, upper lip, cheeks, chin and throat white. There are no claws on the fore feet, and only two small nails on the hind feet. An example of this Otter lived in the Pretoria Zoo for close upon three years, and was a tame and intelligent creature, coming when he was called. He slept in a box containing hay or grass, and was not very regular in his habits, coming out to bathe at all hours of the day and night. He devoured a large daily ration of sea-fish, but accepted and ate with avidity an occasional crab as a special dainty. 
Lutra maculicollis. Spotted-necked Otter. Gevlekte Otter.

This is a much smaller animal than the foregoing, being only about 21 inches in length. Besides being easily distinguishable from the preceding species by its small size, it has the toes of both fore and hind feet

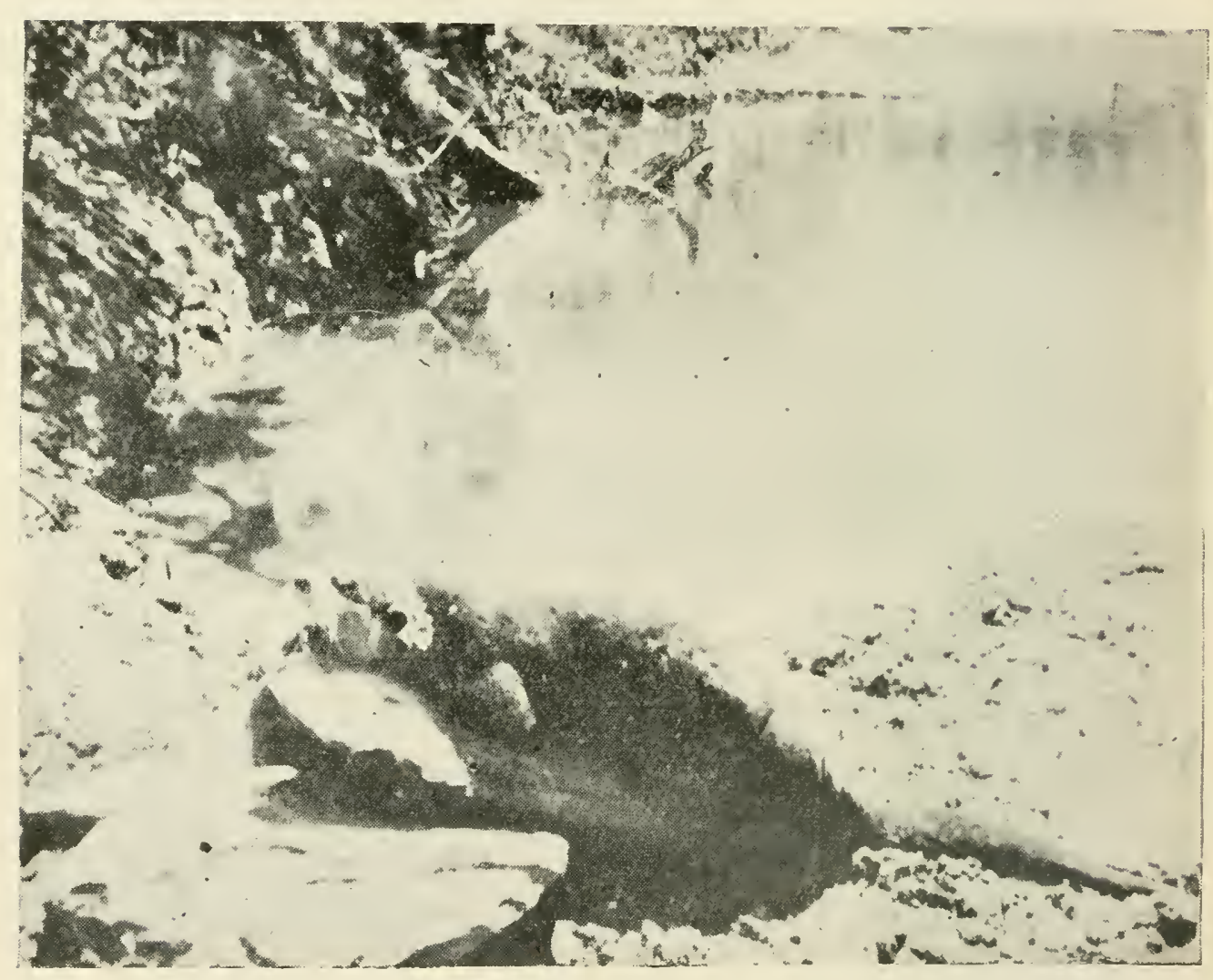

Fıg. 8.-Cape Otter.

armed with strong claws, and fully webbed. The throat and chest are spotted with pale red.

Otters are essentially aquatic animals, living in streams, dams, \&c., where they feed upon fish, crabs and molluscs. We have known of instances where they have ravished poultry runs, devouring the eggs, and killing fowls and ducks. 


\section{Family CANIDA.}

The members of the dog family are easily characterized by their digitigrade feet (bearing four toes on the fore, and either four or five on the hind feet, which are not retractile), well-developed legs and lengthened muzzle. There are four pre-molar teeth on each side above and below, and from two to four molars (usually two above and three below). They have more teeth than the Felidx, the number ranging from 42 to 48.

\section{Genus CANIS.}

Four toes on the front and five on the hind feet. Tail less than half the length of the animal. Pupil round. Dentition (on each side): Incisors three above and three below, canines one and one, premolars four and four, molars two and three $=42$ teeth, which are all strongly developed.

Only two species of this genus are found in South Africa - the Jackals - which are fox-like animals of mostly nocturnal habits, lying hidden during the day-time in a hole or lair under a thick bush. Jackals are fond of decaying flesh, but when this is not available will kill and devour poultry, lambs, game birds and small mammals.

The Black-backed Jackal is common all over South Africa, whereas the side-striped species is scarce, and its habits little known. Tronessart, in his "Catalogus Mammalium," includes these Jackals under' a separate genus, which he calls "Thos."

Canis mesomelas. Saddle-backed Jackal. Rooi Jakihals.

(Also called the Black-backed Jackal, Silver Jackal, and Golden Jackal by the colonists.)

This animal has the back of a mottled greyish black colour, the sides of the body of a reddish hue, the two 
colours being sharply divided by a black line. The underparts are of a much paler tint than the sides. The ears are of large size and of a reddish colour behind.

The tail is bushy and has a conspicuous black tip; length about 13 to 14 inches. The length of the head and body is about 3 to $33_{4}^{3}$ feet. The animal is subject to a good deal of colour variation, ranging from a pale greyish fawn to a brilliant reddish chestnut, but this is largely due to age, season, and possibly even to sex, as I have never seen a female as brilliantly coloured as some males we have possessed. The young pups are of a drabbish brown colour, darker on the back and paler below.

It is fairly evenly distributed over the whole subcontinent, and latterly "Jackal Clubs" have been instituted, with the object of exterminating the animal. It is especially common in the Transvaal Bushveld, where its unearthly howl can be heard any night, the creatures being bold enough at times to come fairly close to the hunter's camp fire. The skins are much prized for karosses.

This animal is much execrated by the Cape farmers on account of the destruction it causes amongst the sheep flocks, especially at lambing time.

Canis lateralis. Side-striped Jackal. Vaal Jahihals.

This is a much more sombrely coloured animal than the preceding, being of a silver or drabbish grey, darker on the back. On each side of the body there is a diagonal whitish stripe bordered on the lower edge by a black stripe. The chin is pale brown; throat and chest reddish brown. The tip of the tail is white, which 
characteristic serves to distinguish it from the other species, even in one-day-old puppies. 'Total length about 21 to 234 feet; tail 12 to 14 inches.

'This species has so far not been found further south than the Magaliesberg Range in the Central Transvaal. In Rhodesia it appears to be fairly common. 'The Zoo has had examples from the following localities: Settlers

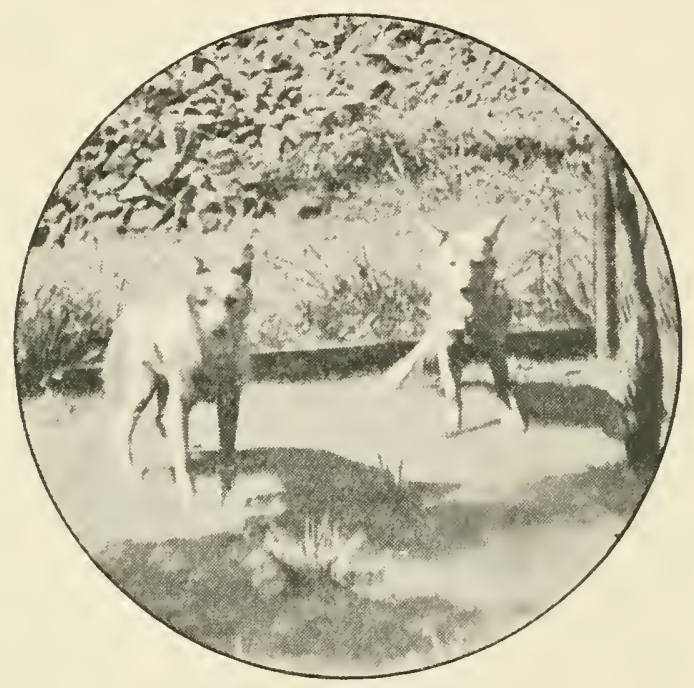

FIG. 9.-Side-strired Jackals.

(District Nylstroom), Sabi Game Reserves, Pretoria, Belfast, Middelburg.

A female in the collection gave birth to two litters, one of three and the other of seven pups; the period of gestation was 57 days and 60 days respectively.

\section{Genus YULPES.}

Muzzle more pointed than in the Genus Canis: form more slender. Tail long and bushy. Pup1l vertically elliptical. Ears large. Teeth similar to those of the Genus Canis, but weaker. 


\section{Yulpes chama. Silver Fox. Zilver Jakinas.}

The colour is of silvery grey above, becoming on the lower portions of the body of a reddish yellow. The fur is long, soft, and of a finely speckled appearance. 'The skins of these handsome little foxes are in great demand for karosses, muffs, furs, \&c. The ears are large and of a reddish brown colour behind, with a yellowish patch at the bases. There is a black patch on the hind leg between the knee and the hock. The tail is almost a foot long, bushy, and of a yellow and black colour with a black tip. 'The length of the head and body is about two feet.

This animal is known in the Natural History books as the Fennec, or the Asse Fox, and to the Boers as the Zilver Jakhals, or Vaal Jakhals, although the latter name is also applied to the Side-striped Jackal, and the former shared by the Black-backed. It is, however, a true fox. It is fairly evenly distributed over South Africa, but is nowhere exactly common. I procured several examples in the Eucalyptus Plantations near the Rand. The Zoo has had examples from Springs, Machadodorp, Middelburg, Klerksdorp, Brandfort, Standerton, Carolina, Heidelberg, Warmbaths, and Pretoria.

Sclater gives its diet as insects and fruit, and says it has never been known to injure stock. We have had some difficulty in keeping these animals alive in vages, but since we have had them transferred to an open camp of fair size with the natural ground for a floor they have done very much better. Their food consists of raw meat, and bread and milk, upon which they thrive fairly well. We have now had one particular individual in captivity for three years. He is very fond of climbing up into the branches of a thick cypress tree growing 
in the camp, and it looks as if the wild birds which perch in the topmost branches are the attraction. He has escuped several times by climbing up the wire netting, but does not wander far from the camp, and is soon recaptured. Another individual, which had been the pet of a little girl, was exceedingly tame, following one about like a dog, and was fond of being petted.

\section{Genus LYCAON.}

Closely resembling the Genus Canis, but differing in the fact that both fore and hind feet possess only four toes each. In addition the skull is more robust.

\section{Lycaon pictus venaticus. Cape Hunting Dog. Wilde Hond.}

This creature is dog-like in-general appearance, standing rather high on its legs. It is of a yellowish colour, irregularly marked with dark brown, almost black patches and blotches. Some examples also have white markings diffused amongst the brown and yellow. 'The ears are large and broad, and the tail is bushy with the terminal half white. The Wild Dog, as it is commonly called in South Afruca, varies very much in coloration. The Transvaal Museum contains a fine mounted pair presented by Major Stevenson Hamilton, of the Sabi Game Reserves, in one of which the black predominates, and in the other the yellow. The length is about $2 \frac{1}{2}$ feet. Tail from 12 to 14 inches.

The Hunting Dog is found all over South Africa, ranging as far north as Somaliland. The Zoo has had examples from Rustenburg, Pietersburg, Lydenburg, Sabi, Piet Retief, and Zululand. It hunts in packs, moving about the country in search of food, seldom remaining long in one place. It has a sharp bark, 
besides its other cries. The farmers execrate this animal in districts where it is prevalent, as a pack has been known to kill from 60 to 100 sheep in a single night. Smuts gives the number of pups at a birth as from ten to twelve, but this seems rather high. Several litter's of four, one of six and one of seven, have been sent to the National Zoological Gardens, which seems a more

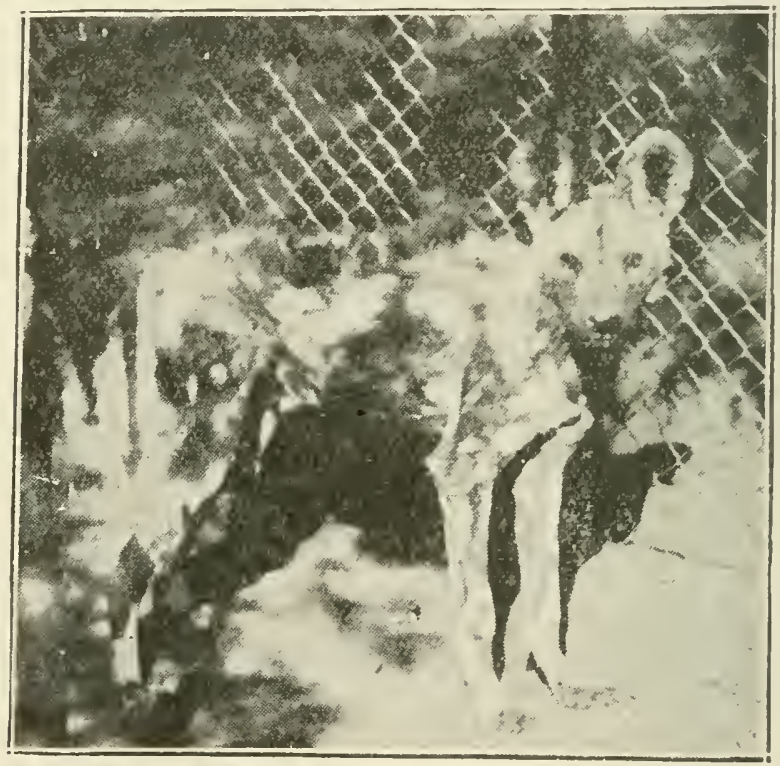

FIG. 10.-Cape Hunting Dog.

likely average. They are brought forth in a hole or burrow. A pair in the Zoo have had two litters, one of four young ones and one of an unknown number. Notwithstanding all precautions having been taken to ensure quiet and isolation, the mother carried the first lot about in her mouth until they were all dead, and the second litter she devoured before they were twenty-four hours old. At one time considerable difficulty was experienced in rearing the pups brought in, :most of them dying of enteritis before they had reached the 


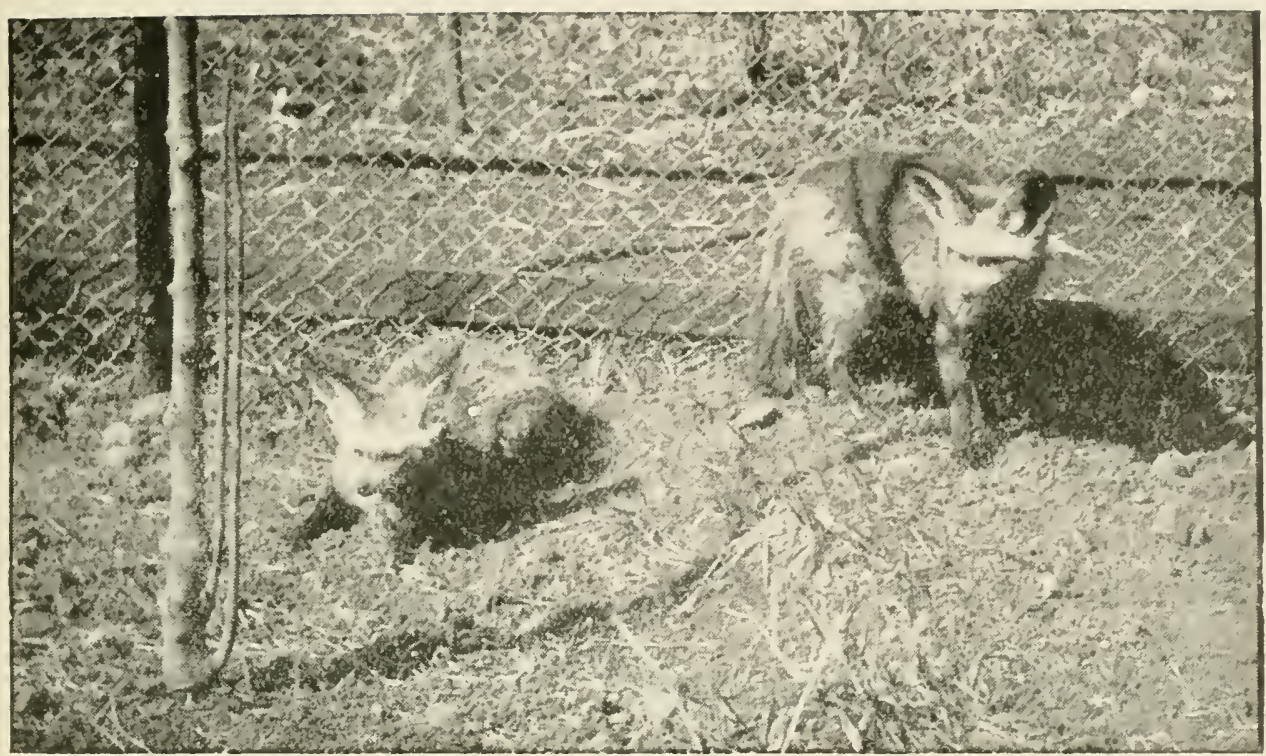

Fig. 11.-Cape Long-eared Foxes.

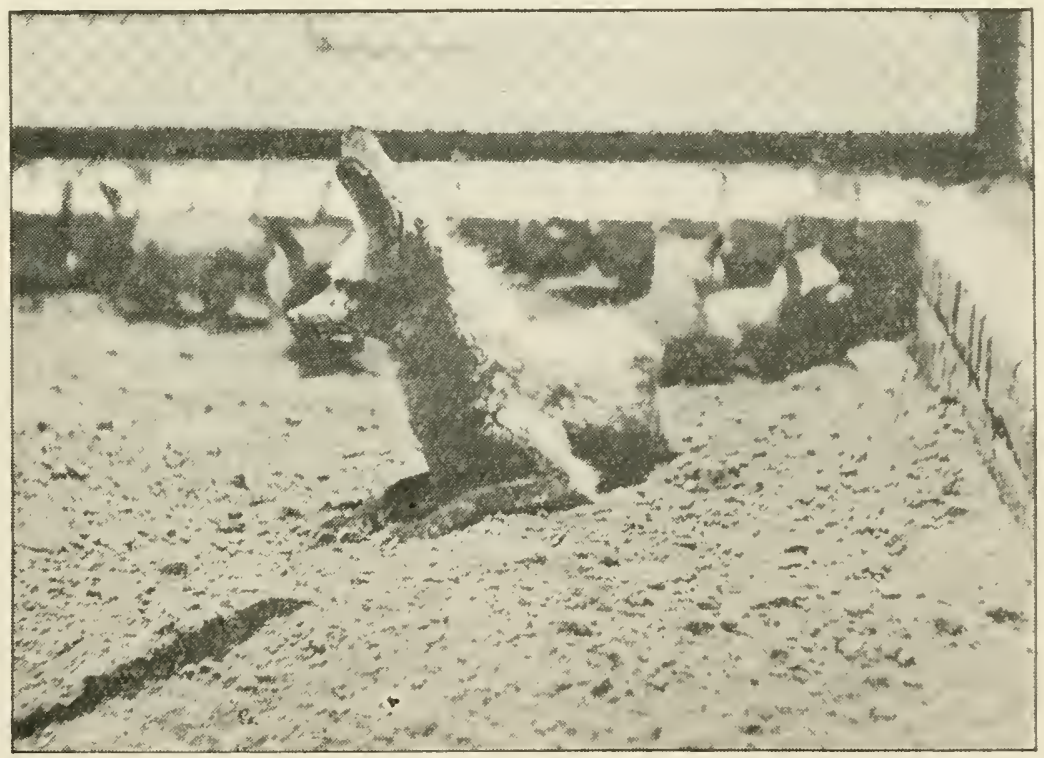

FIG. 12. - Cape Long-eared Fox and Young (ten days old). 
age of six months. The writer then had the young ones placed in a large camp with the earth as a natural floor and fed them sparsely, with the result that the exercise and low feeding, with an occasional gorge (on tripe), proved successful.

\section{Genus OTOCYON.}

Animals resembling the fox, but with very long ears; five toes on the hind and four on the fore feet. Teeth 4.5 to 48 in number.

Otocyon megalotis. Cape Long-cared Fox. Draai Jalihals.

This animal is very much like the Silver Fox in its general coloration and appearance; it is however of a darker grey, the upper parts being without any trace of yellow.

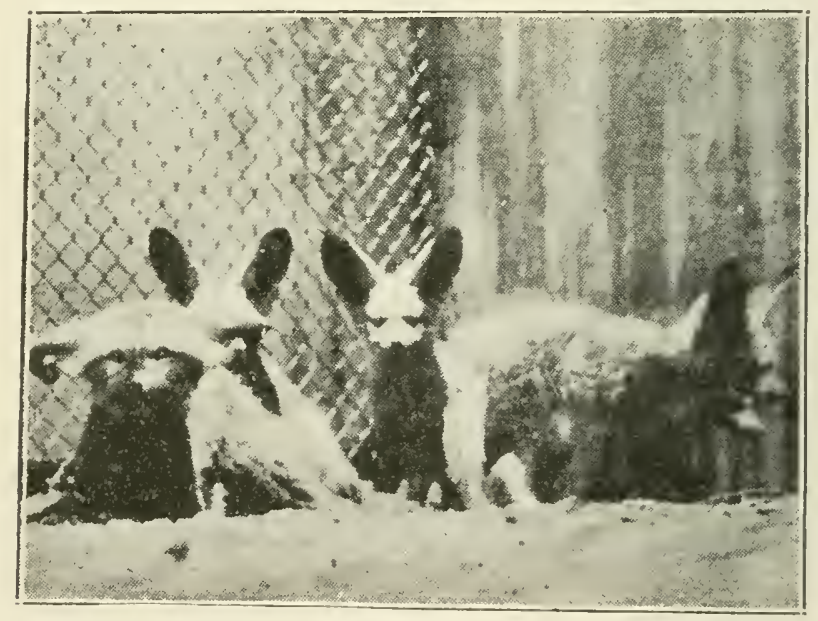

Fig. 13. - Cape Long-eared Foxes.

(Mother and cubs, three months old.)

'The chin is dark brown, while the under parts are very pale-almost white. There is a dark streak through the eyes and one down the centre of the nose. Ears very large, standing up lilie those of a clipped bull-terrier; the 
tail is thick and bushy, the terminal third being black. Length about 2 feet, tail 1 foot.

It inhabits the western portion of the sub-continent, ranging as far east as Uitenhage, in the Cape Province. It is nocturnal in habit, going about in pairs as a rule; it is a fairly omnivorous feeder, small rodents and insects forming the bulk of its fare. In the Zoological Gardens they live principally on bread and milk and raw meat. They are especially fond of monkey-nuts (ground nuts), which are given to them several times a week. They become very tame in captivity. A female possessed by us for some years reared several litters of three, the period of gestation being practically the same as that of the Side-striped Jackal, namely sixty days.

This little animal has a lovely thick fur, and its pelt is much prized for furs and muffs. It is known to the furriers and curio-dealers by its native name of "Macloutsie."

The Zoo has had examples from the Northern Cape Colony, and from the Rustenburg, Bank, Zeerust and Pretoria districts in the Transvaal.

\section{Family HYAENID无.}

Digitigrade animals of carnivorous habit, with the fore quarters higher than the hind ones, the back sloping downwards.

\section{Genus PROTELES.}

Fore feet with five and hind feet with only four toes, The claws are not retractile, and the mode of walking is digitigrade. The dentition is weak. The form is hyaena-like. 
Proteles cristatus. Aardwolf. Manhaar Jakihals.

This animal is hyaena-like in build, but smaller; of a yellow-grey colour, banded by black stripes, which are wide apart. Legs banded with blask, the portion below the knee and hock quite black. 'Tail short, bushy, and blacli-tipped. The hair along the back is long and crestlike, which gives to the animal its Boer vernacular name of "Manhaar Jakhals" (Maned Jackal). Length about $2 \frac{1}{2}$ feet, tail about 10 or 11 inches.

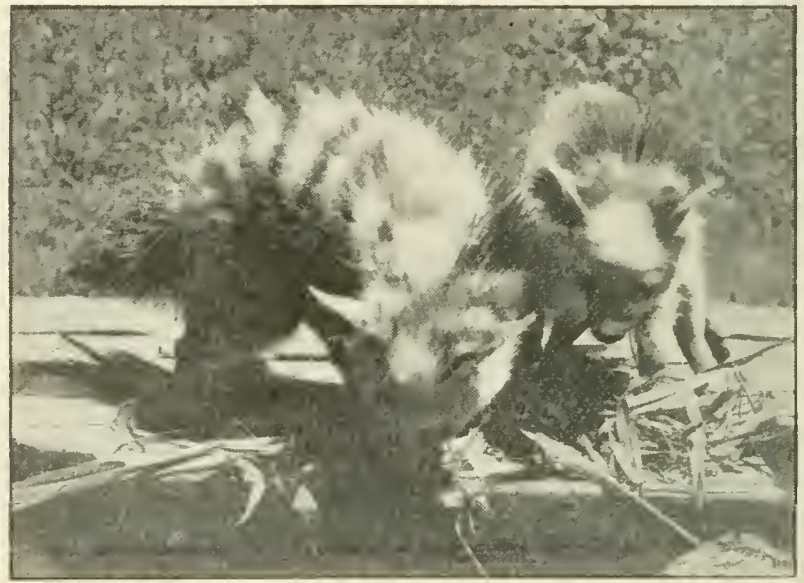

Fig. 14.-Young Aardwolves.

The Aardwolf is a cowardly, skulking, harmless animal, ranging from the Cape to Somaliland. It is mostly nocturnal in habit, passing the day in a burrow or lair in a thick bush, and is found in bushy country, as well as on the open veld. I have seen them prowling about in search of food in the evening after sunset, and on one occasion in broad daylight. Their food appears to consist mainly of insects, especially ants and termites, but probably includes small animals, birds, reptiles, \&c., when procurable. I have not bred this animal yet, but judging by the litters brought in for sale, the number 
varies from two to four, the former being the more usual; it is a timid, retiring animal; we had one half-grown specimen, which was very tame and would come for his food when called. It is a difficult animal to rear and keep in captivity.

\section{Genus HYAENA.}

Four toes on each foot, supplied with non-retractile claws. Tail short. Teeth 34, which are powerful and well adapted for crushing bones. There are two species in South Africa. They are nocturnal animals, remaining concealed during the day in holes, caves, or lairs in thick bush, and issuing forth at night in search of dead animals, which are their favourite food, although they will kill and devour sheep, calves, donkeys, \&c.

They are cowardly animals, as well as greedy, and have excellent powers of scent and hearing. The dismal howl of the Hyaena is proverbial, the spotted species also emitting a maniac-like laugh, whence the name "Laughing Hyaena."

Hyaena brunnea. Brown Hyaena. Strand Jut.

This is the Strand Jut or Strand Wolf of the colonial; it is of an ash-brown colour, the hair on the hinder portion of the back being long. Throat, chin and cheeks very dark-nearly black. Legs banded with dark brown. Length of head and body about 4 feet, tail 1 foot.

This species is more or less confined to the southwestern portion of South Africa, ranging as far north as the Zambesi. It is still not uncommon in the Pretoria and Rustenburg districts. We saw a fine old male caught in a gin-trap on June 7, 1914, on the farm Buffelsdraai, about 50 miles north of Pretoria. 
Hyaena crocuta. Spotted Hyaena. Gevlekte Wolf.

The Tiger Wolf, or "Wolf" as the colonials usually call this animal, is of a yellowish-grey colour, the body being covered with round dark brown or black spots or blotches. Tail tipped with long black hair. Length about 4 feet 6 inches. Tail 14 inches. This species seems to be distributed over the whole of South Africa, and was at one time common in Cape Colony. The Zoological Gardens had one of these animals for five years, which had been obtained by Major Hamilton at Sabi. This individual often emitted the unearthly howling laugh characteristic of the species, more especially towards sunset. It was destroyed after a long course of fits, in which it got knocked about rather badly. A second example, presented by Mr. Thÿs Uÿs, of Groenvlei, Piet Retief, was exceedingly tame, would come when called by name and allow himself to be patted and stroked. This animal indulged in wonderful gambols at sunset, racing round his cage, spinning round like a top, and jumping about in the exuberance of good health and spirits.

Trouessart, in his "Catalogus Mammalium," enumerates three species of Hyaena in South Africa, the third being Hyaena capensis.

\section{Family VIVERRIDA.}

This is a somewhat variable family of small carnivorous animals confined to the Old World. Some of the members of the group are plantigrade, while others are digitigrade. The body and head are both elongate in shape, and the limbs fairly short, as compared with the Felidee. The second pair of lower incisor teeth usually project above the level of the first and third pairs, while the 
upper carnassial is without the anterior lobe characteristic of the foregoing family. The premolars are three to four and the molars one to two in number on either side, both above and below. Well developed perineal scent-glands are usually present. Alisphenoid canal generally present.

\section{Genus YIVERRA.}

Body somewhat stout; limbs fairly long and tail short and tapering. The underside of the tarsus is quite covered with hair and all four feet are furnished with five claws.

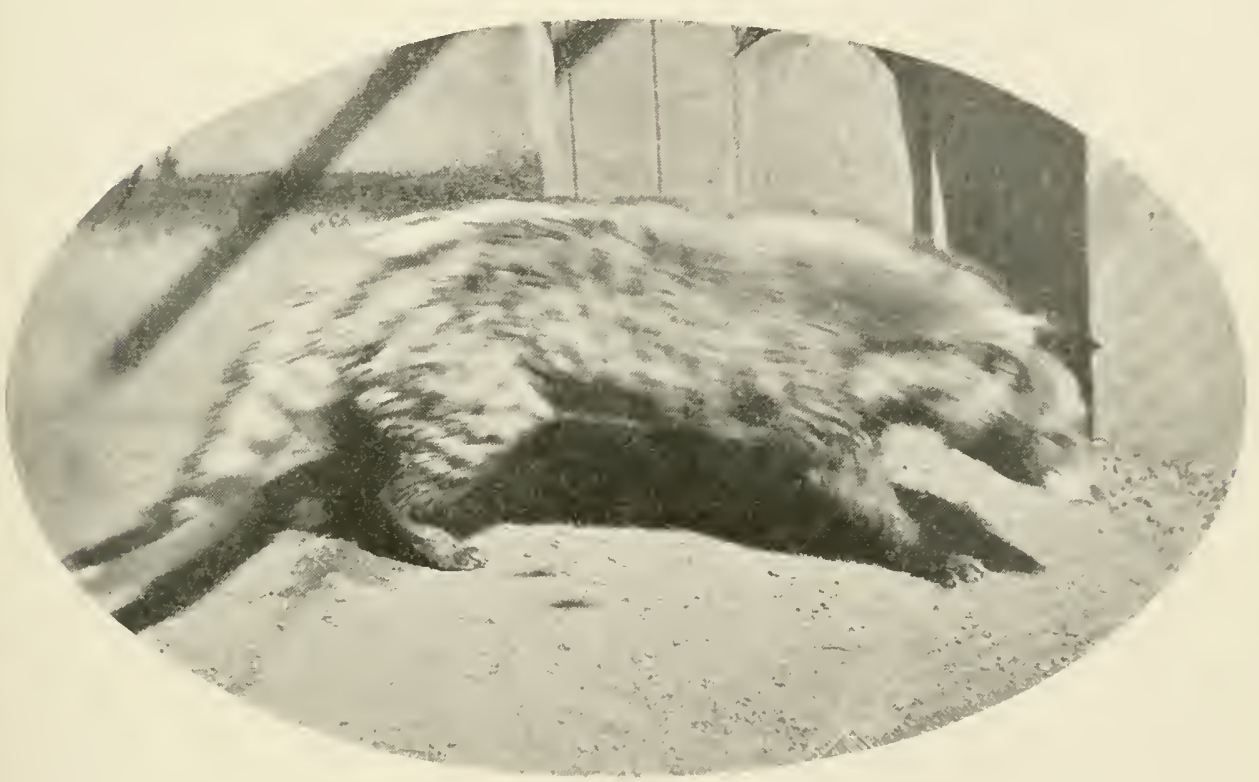

FIG. 15.--African Civet Cat.

Yiverra civetta. Civet Cat. MInstius Kat.

Ground colour yellowish to slaty-grey, marked with dark brown spots and blotches, the markings arranged more in the form of bars on the fore part of the body. The ears are large, rounded in shape, and with white tips: the hair along the back is fairly long, forming a 
mane-like crest; tail tapering and ringed with black and white, tip black. Total length of animal about 4 feet.

This animal is found throughout the warmer parts of Africa, extending as far south as the Central and Eastern Transvaal. The Zoo has had examples from the Sabi Game Reserves, the Rustenburg district, and from Hectorspruit in the Eastern Transvaal. An individual from the first-named locality, presented by Major $J$. Stevenson Hamilton in May, 1908, is still alive. Its diet consists of raw meat, bread and milk, and occasionally a few raw eggs. Owing to its being largely a nocturnal animal little was previously known of its habits, but Major Hamilton, in his interesting book "Auimal Life in Africa," gives a fair account. He says: "It favours thick bush and is solitary and nocturnal, lying hidden during the daytime in the grass, under a bush or in a hole in the earth. Its food consists of berries, ants, locusts and other insects, lizards and frogs, as well as rats and mice and other small rodents. Carrion is also eaten. In addition to the foregoing varied bill of fare it will devour the eggs and the young of game birds, and will even steal poultry when opportunity offers."

\section{Genus GENETTA.}

Small animals with long slender bodies, short limbs and long tails. The ears are long and prominent. The metatarsus has a narrow line of bare skin running up to the heel, which characteristic is sufficient to distinguish the members of this genus from Viverra. There are five toes to each foot. These animals have the power of emittmg an evil-smelling fluid from the perineal glands. South Africa possesses a number of species, ranging pretty well over the whole country. They are nocturnal, 
remaining concealed during the daytime under a bush, in a tuft of grass, or in a tree. 'They feed upon insects, birds, small mammals, and ravage the poultry yards when they get an opportunity. 'I'o the Boers they are known as Nosiliaat Katten. Thomas and Wroughton give the following key to the two groups into which these animals naturally fall (see P.Z.S. for October, 1908, "Mammals from Zambesi ") :-

A. Forefeet black.

(a) Hairs of dorsal crest and tail long (at least $50 \mathrm{~mm}$. near base of tail); dorsal spots relatively small, with a distinct tendency to coalesce into longitudinal stripes, tail-tip white-felina group.

(b) Hairs of dorsal crest and tail short (not more than $35 \mathrm{~mm}$. at base of tail) ; dorsal spots large, always distinct, tail-tip black-tigrina group.

\section{GROUP B.}

Genetta rubiginosa. Large Rusty-spotted Genet. Groote Roodgevlekte Mosiliaat Kat.

'This species would appear to be the northern representative of the Cape Colonial G. tigrina, as it resembles this animal in the large size of the blotches and in the absence of a pronounced dorsal crest (or mane) along the back. The ground colour is a sandy-grey or yellowishdrab, and the spots are of a rusty-red or chestnut-brown, often surrounded by a blackish ring. This latter characteristic was the main reason for the description of a new species-G. letabe-by Messrs. Thomas and Schwann in 1906, from specimens collected in the Eastern and Northern Transvaal by C. H. B. Grant, but which they discarded at a later date upon the receipt of a larger 
series of skins. As far as I can judge from the examples which have passed through my hands in the Zoological Gardens, the younger animals possess these dark edges to the blotches, and the older the animal becomes the paler the blotches get, and the fainter the rings appear. I make this assertion as I have received several halfgrown animals with the blotches of a reddish-brown, and the dark rings very pronounced, while other's again-the largest received, and seemingly old animals-were with paler spots without the darker margins, or these but faintly discernible. Legs pale greyish-fawn, only the soles of the hind feet being dark brown. The spots of the lower half of the hind legs are dark brown, as well as the rings of the tail. This species is apparently not found south of the Central Transvaal, except on the east. The Zoo has had examples from the Pretoria district, Tzaneen and Natal.

Genetta tigrina. Large Black-spotted Genet.

Groot Zwartgevlekte IIosiliaat Kat.

Ground colour grey, of a paler tint, shaded with yellowish in some individuals. There is a black stripe along the back. The sides of the body are spotted with large squared blotches of black, arranged in three longitudinal rows. Ears sparsely clothed with white hairs. Legs, from above the elbow joints downwards, of a black colour. 'Tail long and ringed with black and whitish, the tip being black. Length of head and body about 23 inches, tail 17 to 18 inches. The animal is fairly common in the Cape Province, but does not seem to be found north of the Orange River. The Zoo has had examples from Kingwilliamstown and Nowbray, C.C. 


\section{GROUP A.}

Genetta felina. Small Black-spotted Genet.

Klein Zwartgevlekte Mosiliaat Kat.

Resembling the previous species, but the spots are much smaller, and are arranged in five rows. The bair of the back and tail is much longer than that of tigrina, as already stated in the Key, and forms a crest or mane. The upper portion of the forelimbs is of the same colour as the body in front, the lower portion being black; the legs black behind. All five toes are white. The tip of the tail is also white. Length of head and body 24 inches. Tail $17 \frac{1}{2}$ inches. This species ranges from the Cape, through Natal and Zululand, to the Eastern Transvaal, where it seems to overlap with the succeeding species (G. ludia). The Zoo has had examples from the Pretoria district and the Sabi Reserve in the Transvaal, and from various districts of the Cape.

Genetta ludia, Thomas and Schwann.

Small Rusty-spotted Genet. Klein Roodgevlekte Mosiliaat Kat.

Similar to G. felina, but the spots on the body, especially those on the lower portion, are of a dark rusty-brown, often more or less coalescing into bars or stripes. The forelimbs are of the greyish fawn or drabbish tint of the body, and are without the black lower half characteristic of felina, the rear margin only being black. The stripe along the back is black, like that of $G$. felina.

I am not certain, with the paucity of literature at my disposal, whether this is not Matschie's zambesiana, but pending further investigations I give it the name chosen for it by 'Thomas and Schwann from specimens collected in the North-Eastern Transvaal by C. H. B. 
Grant. This species puzzled me for a long time, and I first considered it the young or immature form of G. felina. The receipt, however, of a typical adult felina female, with a litter of three young ones, followed shortly afterwards by half-grown young ludia, captured in the Pretoria district, caused me to reject this theory. Then the Rudd Zoological Survey papers appeared, with the result above mentioned. In the Pretoria district it is the commonest species, and G. rubiginosa is also found here, but so far tigrina has not been brought to me from the district. The collection has had examples of this Genet from the following localities: Pretoria, Rustenburg and Pietersburg.

Genets remain fairly fierce and shy creatures in captivity, lying hidden in their beds of hay or crouched on the trunk of a tree during the day. They are, moreover, quarrelsome brutes, and we have lost a number of them owing to free fights having taken place from time to time amongst the inhabitants of a cage.

\section{Genus HERPESTES.}

Ears very short and broad, hardly projecting above the level of the surrounding hair. There is a narrow naked groove running down from the nose to the upper lip. The hair of the body is of a grizzled appearance owing to the individual hairs being ringed with two different colours. They are from small to medium sized animals, of chiefly carnivorous habits.

Herpestes caffer. Large Grey Mongoose.

Groot Vaal Murshond.

This is the largest species of the genus, measuring some 26 inches in length, exclusive of the tail, which is 
auother 18 inches. In colour it is a speckled grey, the hairs being ringed with black and white. Tail tapering towards the tip, which is black.

It is recorded from Knysna, C.P., whence the 'Transvaal Museum has obtained specimens. Mr. C. H. B. Grant says it is now rare in that locality owing to its fondness for chickens, which has caused its destruction. The Zoo has obtained examples from Natal and the Gastern Cape Colony.

Herpestes galera. Water Mongoose.

Groot Zwarte IIuishond or Kommetje Kat.

This animal is nearly as big as the preceding species, being 24 inches in length, with a tail of 13 to 14 inches. It is a somewhat thickset animal, dark brown in colour, the hairs being ringed with blackish or dark brown and pale yellow. The legs are darker brown, the hairs on this region not being ringed.

The tail is tapering, being bushy at the base and graduating towards the tip, which is a little darker than the basal portion. The Water Mongoose is partly aquatic, taking to the water when pursued. Its usual haunt is a reed or rush-bed on the bank of a river, stream, or vlei-or in the long grass bordering the vleis. In captivity it is fond of lying in the water basin, or splashing the water about until the receptacle is empty. Mr. Woosnam procured it at Kuruman in Bechuanaland, and says its food consists chiefly of fish, frogs and crabs. 'The Transvaal Museum contains specimens from Knysna, C.P., and the Zoo has obtained examples from Elizabethville (Belgian Congo), Bank, Brits, Pietersburg, Lichtenburg, and Pretoria (Transvaal).

When captured young, it makes a tame and amusing pet; indeed, we have possessed examples quite as tame 
as the ordinary Mierkat. They thrive well upon bread, milk, raw meat and hard-boiled eggs.

Herpestes pulyerilentus. Small Grey Mongoose. Klein Grys Kommetje Kat.

This is a small edition of the Grey Mongoose, and is principally found in the Cape Province. It is about the same size as the Slender Mongoose.

Herpestes albicauda (Ichneumia a.). White-tailed Mongoose. Witstaart Kommetje Kat.

This is a larger animal than the Water Mongoose, but with a more slender body. It is of a grey colour, with the legs, from the elbow downwards, of a blackish hue, The latter two-thirds of the tail is white. The length of the animal varies from 22 inches to 24 inches. The tail is another 16 inches. In Natal this species seem to be common. The Zco has had examples from Natal. Tzaneen (Northern 'Transvaal), Pretoria District and Barberton.

In captivity it is the wildest and shyest of the Mon. goose tribe, showing itself only at night. It will eat raw meat, and bread and milk.

Little is known of its habits in a wild state.

Herpestes gracilis. Slender Mongoose. Rooi Mierkat.

This is a small slender little creature, of a grizzled yellowish or reddish brown colour, with the limbs and underparts generally paler than the back and sides. It has a long black-tipped tail. Total length of body, 12 inches. Tail, 11 inches.

This species has been split up by European naturalists into several sub-species or geographical races, which need not concern the beginner in Natural History nor 
the sportsman-naturalist. 'The sub-species usually found in the collection of the Pretoria $Z 00$ is $H$. gracilis typicus, and we have obtained examples from the Pretoria district, where it may usually be found in stone walls or rocky kopjes.

If captured young it makes a tame and amusing little pet, but does not become so confiding nor so tame as the Suricate. It is, like its congeners, practically a carnivore, but it will devour insects such as grasshoppers, locusts, ic., and birds' eggs, whenever opportunity offers.

There are several other species of Herpestes (or Mongos, as they have also been called generically), viz., H. ruddi, $H$. punctatissimus, which we have so far not met with.

\section{Genus HELOGALE.}

Pigmy MIongoose. Dwerg Kommetje Kat.

Body slender and legs short; tail tapering. Naked line between nose and upper lip. Tarsus naked; five toes to each foot. Teeth 36 (i., $\frac{3}{3} ;$ c. $\frac{1}{1} ;$ p.m. $\frac{3}{3} ;$ m. $\frac{2}{2}$ ).

The Pigmy Mongoose (H. parvula), and its Eastern representative, but recently described, $H$. brumnula, are the smallest members of the Viverridce, being only 8 to 9 inches long, with a tail another $5 \frac{1}{2}$ inches.

The former is of a dark grizzly grey brown, and the latter of a dark speckly brownish-slate colour. We have possessed quite a number of the latter species from Hectorspruit, in the Middleburg district of the Central Transvaal, and from the Rustenburg and Pretoria Bushveld. At first they are of a wild, shy, and retiring nature, dashing into their caves or grottoes at the least external disturbance, or at the approach of anyone, but after some months they become tamer, and will allow themselves to be seen. We have fed them upon finely chopped 
raw meat, hard-boiled eggs, and bread and milk. The egg seems to be necessary, and takes the place of the insects they feed upon in their wild state. A female gave birth in the Zoo to two litters-the first of two, and the second of four young ones. It was a pretty sight to watch the little ones, no larger than a mouse, playing about in the bright sunlight like kittens.

\section{Genus CROSSARCHUS.}

No naked line from nose to lip. Other characters as in Helogale.

C. faciatus. Banded Mongoose. Gestreepte Kommetje Kat.

This is the common species of the Natal coastal belt, ranging westwards into Bechuanaland and northwards to Rhodesia. It is of a grizzled grey, banded on the hinder portion of the body with dirty white, reddish and black, the hinder portion of each white stripe shading from white, through reddish, to black. The tail is black towards the tip. Length of head and body, 16 inches; tail, 8 inches.

It lives in small communities, more resembling the true Mierkat in habits than those of a Mongoose. It feeds upon fruit, insects, \&c. Mr. C. H. B. Grant says it is not common, and it frequents the thornbush and thickly wooded sluits and river banks, usually in parties of six. I found it fairly plentiful between Palapye Road and Serowe in Bechuanaland, and its skins very often adorned the karosses of the local natives. It becomes very tame in confinement, and like its relative the true Mierkat, makes a lovable pet. It will eat meat and the usual articles of diet mentioned in regard to the other species. 


\section{Genus CYNICTUS.}

No naked line from nose to lip. Five toes on the fore and four on the hind feet. Tarsus hairy.

Cynictus penicillata. Thick-tailed Mongoose. Geel Mierkat

(Yellow Meercat of the colonials.)

Colour yellowish, darker in some, paler in other individuals. 'The tail is bushy and has a white tip. Length of head and body, 15 inches; tail, 9 inches.

The Yellow Mierkat is found in the Eastern Cape Colony, ranging as far north as Lake Ngami and Southern Rhodesia. It is very common in the Orange Free State, where the writer met with it in the Bloemfontein and Kroonstad districts, and in the Central Transvaal about Johannesburg and Pretoria. I have also come across them at Serowe in Bechuanaland, and at Volksrust in the South-Eastern Transvaal.

They live in small colonies or family parties, constructing burrows on the veld, at the edges of which they may often be seen sitting up on their hind legs and looking inquisitively' round them, ready to pop into their holes upon the approach of an intruder. I have often noticed in the Orange Free State that they live cheek by jowl with the Ground Squirrel, both species inhabiting burrows in close proximity to one another. They are fairly fast runners, and are adepts at the art of doubling; hence it is not such an easy matter to catch them with a dog as is popularly supposed. They live on insects, small rodents, and birds which they stalk in the grass after the manner of a cat. Birds' eggs are also a favourite article of diet.

Although I have seen very tame individuals, it does not become anything like the tame confiding pet the 
Common Suricate invariably makes, being naturally of a much fiercer disposition. It is also of more carnivorous habits than the Mierkat, and I would warn owners of a tame Thick-tailed Mongoose to beware of their pet if any young chickens should happen to be about. In captivity they require little else than raw meat, but an occasional rat or bird will help to keep them in condition.

A second species (Cynictus selousi) was described by de Winton from a skull picked up in South Rhodesia.

\section{Genus SURICATA.}

Little animals with a slender snout, and without the naked line from nose to lip. There are only four toes to each foot; the claws of the fore limbs are very long. The tarsus is naked and the tail is tapering and without the bushy appearance so characteristic of the Mongoose family. Ears small and rounded.

Suricata tetradactyla. True Mierkat. Graatje Mierkat and Stokstacert Mierkat.

In general coloration this little animal varies from grizzled grey to a tawny grey colour, banded on the back with indistinct dark brown or reddish brown bars. The tail is relatively short, has a black tip and is not bushy. Length of head and body, 12 to 14 inches; tail, 6 to 8 inches.

It is one of the commonest and most sought after pets in South Africa, as it becomes very tame and confiding, running about the house loose, and following the inmates like a dog. It has one objectionable habit, to my mind, and that is the little whining bark it emits, sometimes for half an hour at a stretch, which is apt to become irritating after a time. It is a courageous little animal, and will walk up to a strange dog, no matter how big 
the latter may be. This pluckiness, combined no doubt with curiosity, has been the cause of the untimely death of many a household pet. In captivity it will eat almost anything, but raw, finely-chopped meat and hard-boiled eggs should form the staple diet.

In the wild state it lives in colonies or family parties in burrows like its near relation, the Thick-tailed Mongoose, and like it, is fond of lying basking in the sun or sitting up on its hind legs near the burrows. It feeds upon insects and their larve, bulbs, as well as small rommals, such as mice, wc., reptiles, birds and their eggs, when procurable. It ranges from the Western Cape Colony through the Tiaroo, Orange Free State, and Namaqualand to the Southern Transvaal. It is especially common in the Central Orange Free State where it may often be found in fair-sized colonies on the open veld. Generally two young ones are born at a time, which are reared in a nest at the end of the burrow. A pair in the Zoo gave birth to three half naked and blind young in February, 1919. Unfortunately they did not live long, as the mother insisted upon carrying them about in her mouth until they were dead.

\section{Family FELIDE.}

Feet digitigrade (viz., the animal walks on the tips of the toes) with five toes on the fore, and usually four on the hind, feet; toes armed with sharp claws, which are quite retractile, except in the single case of the Hunting Leopard or Cheetah. Skull, short and rounded; teeth, twenty-eight to thirty, with the canines strong and well developed. 
Cynailurus jubatus guttatus. Hunting Lcopard.

Tier or Jacht Tier (Tijger).

Panther, of the colonials. Cheetah, of the AngloIndian, which is the name generally given to it in the Natural History worlis.

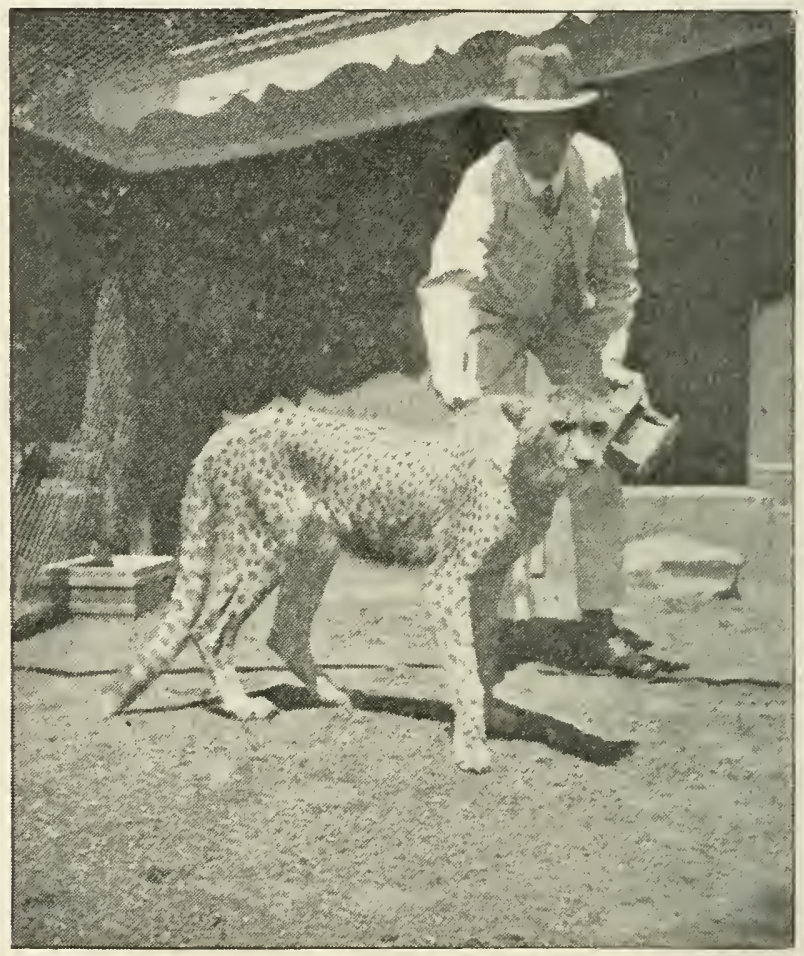

Frg. 16.-Hunting Leopard, or Cheetah.

This graceful creature is placed in a separate genus by itself, mainly on account of its claws being only partially retractile. In general coloration it is of an ochreous yellow, more sandy in some individuals, profuseì marked with solid rounded black spots. As a rule, the upper portions of the body are darker and more inclined to reddish than the lower. The hair is thick on the nape and shoulders, stanaing up in the form of a mane or 
crest. The head is blunt in shape, and the ears short and rounded. The tail is long, with the tip bushy. A fine mounted example in the Transvaal Museum, which lived for a long time in the Zoo, measures: Length, $3 !$ feet exclusive of the tail, which is another $2 \frac{1}{2}$ feet; height, 28 inches. The Hunting Leopard or Cheetah

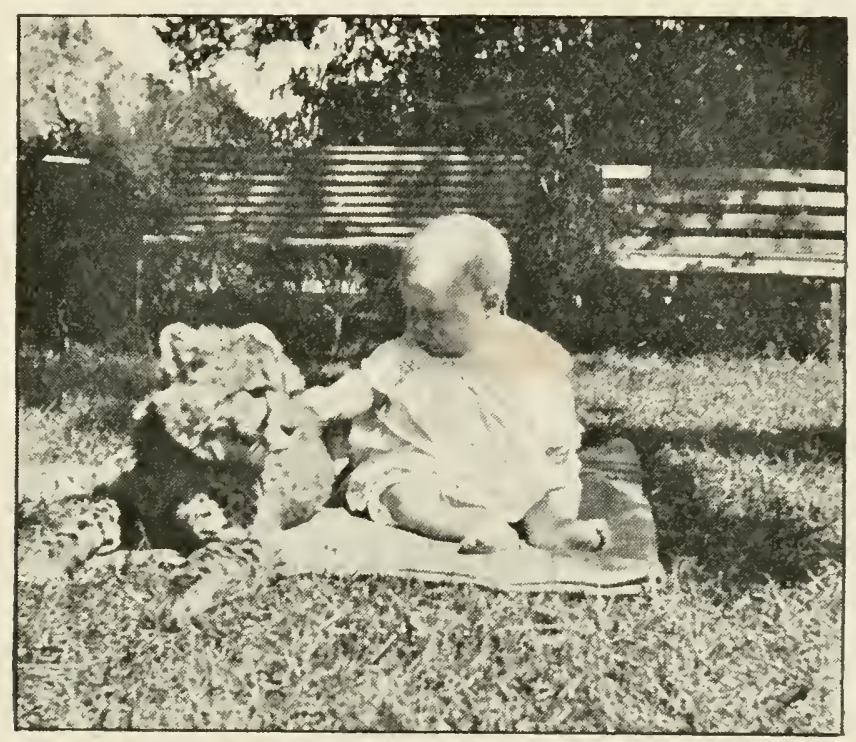

FIG. 17.-Cheetah Cub.

stands higher on its legs than a true Leopard, being more dog-like in build. Its geographical range resembles that of the Caracal, but in South Africa it is now seldom seen, being commonest in Bechuanaland and the Sabi Game Reserves of the Eastern Transvaal. The Zoo has now a lovely example captured in the Waterberg district of the Transvaal, and presented by Mr. and Mrs. Bateman: "Billy," as he was named by his former mistress, is - like most Cheetahs - of a friendly and amiable disposition, and answers fairly readily to his name, purring loudly when called and spoken to, and usually coming up to the bars of his cage for a caress. 
$\mathrm{He}$ is so tame that he can be handled while he is at his meal, which is a very unfeline-like trait. There was for many months a tame true Leopard in the next cage to Billy, and although to all intents and purposes of as docile a nature as the Cheetah, the difference between the two became immediately apparent at mealtimes, as the Leopard's nature changed at once, and she had to be chained up to a stake in the ground before her meat was brought into the cage, the smell thereof causing her to become excited and obnoxious. As is well known to naturalists and people living in India, the Cheetah is tamed by the Hindoos to hunt the Blackbuck, and is one of thenfleetected atmos nown.

It inhabowopen grasmeuntry or grass veld dotted with scattered bush, seldom resorting to heavily timbered tracts. In South Africa its food consists mainly of the simaller antelope, such as Duiker, Steenbuck, \&c., and I believe Baboons form, when available, a special delicacy. Besides the Waterberg district, the Zoo has had examples of the Cheetah from the following localities: Nyasaland, ex-German South-West (" Bernard," still living and presented by Lieutenant Wimble, S.A.M.R.), and from Malalane, Eastern Transvaal (Captain Atmore).

Felis leo. Lion. Leeun.

This animal, called the "King of the Forest" and the "King of Beasts" in the story-books, needs but little description. It is of a general tawny or sandy-yellow colour, with a black patch at the base of the ears. The males possess a mane, which in some examples is coloured like the body, while in others the hairs are strongly tipped with black. In some the mane may be very scanty and restricted in area; in others it may be thick and busby, extending over the shoulders and along the 
larger game, mainly antelopes of all kinds, but also includes zebras, giraffes, and buffaloes. They will kill the donkeys and cattle belonging to prospecting and hunting parties, and will raid Kaffir lraals when driven to it by hunger. Man-eating lions are generally old animals with bad teeth. 'They usually drink in the evening between sunset and 10 p.m. Their call is the well-known and awe-inspiring roar, but the lion also emits a lind of coughing grunt. 'I'wo to four cubs are born during the months of November to March. The period of gestation, as first observed by Bartlett in the London Zoo, and verified by me in the Pretoria Zoo, is sixteen weeks. The lion is easily tamed, and forms, with the Bengal tiger, one of the chief attractions of a circus or menagerie. The lion has also been crossed with the tiger, the cubs being very pretty animals.

Lions are, however-like most of the cat tribe-of uncertain temper, although less treacherous than most felines. Two cubs born in the Pretoria Zoo were, when young, quite devoid of any fear for human beings, making no attempt to run away when approached, and they had finally to be lifted up and carried froin one cage to another, refusing to be scared thither by sticks and shouts. The eyes of the two cubs were open on the sixth day. A fine lion in our collection is very tame, and usually comes for a caress when called. The collection also contains an interesting and much travelled old lioness. This animal ("Beauty" by name) was given by the late Cecil John Rhodes to the President of the South African Republic (the late Paul Kruger), but was returned to the donor, who then sent her to the London Zoo. After the Boer War the Zoological Society, upon being informed of the existence of the then embryo Zoo in Pretoria, kindly sent "Beauty" out again, and she 


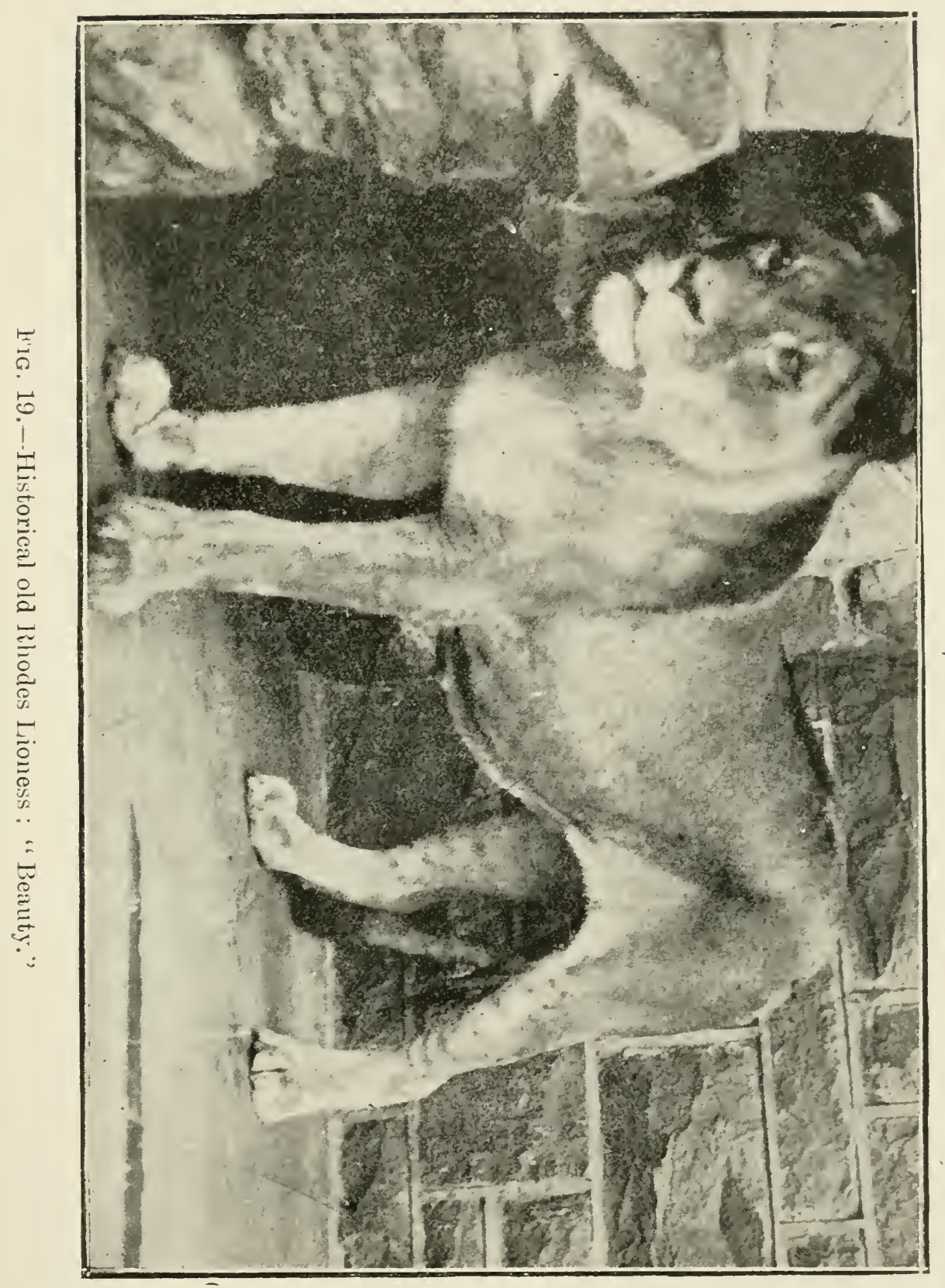




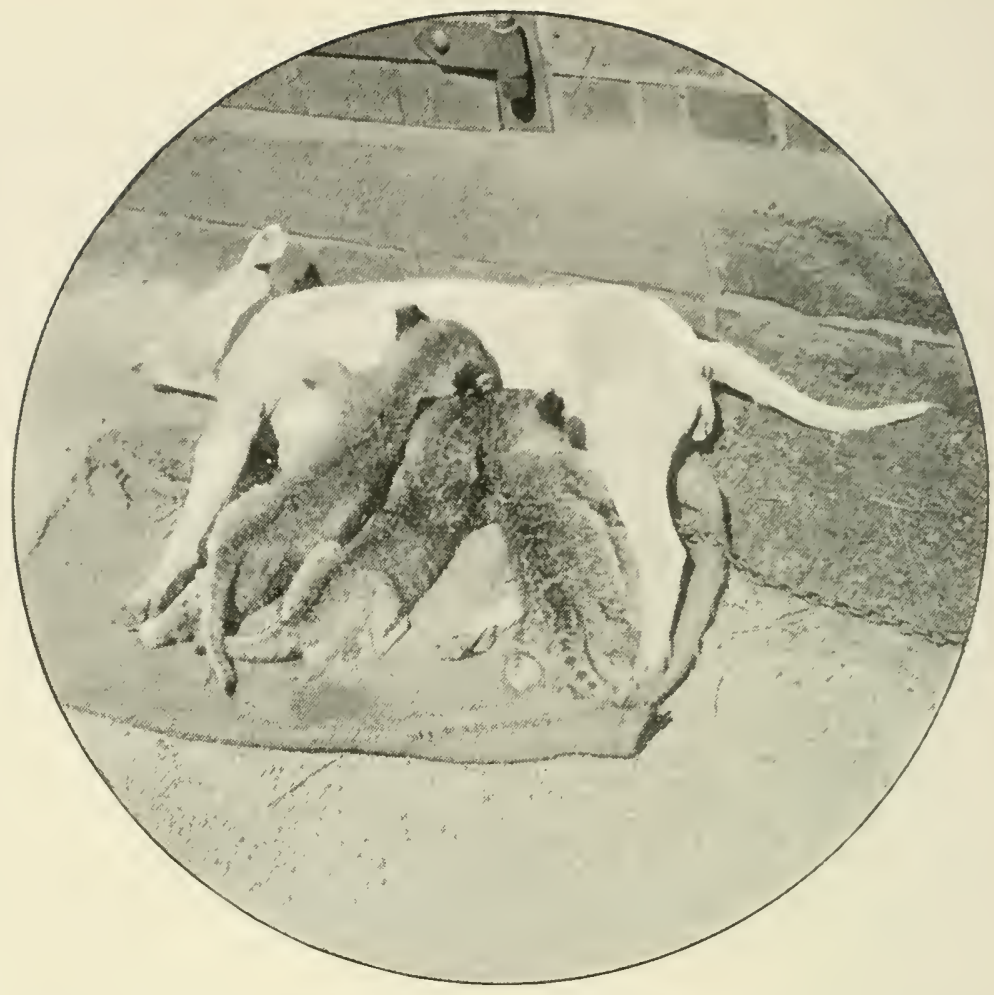

FIG. 20.-Six weeks old Lion-cubs (suckled by Bull-terrier Bitch).

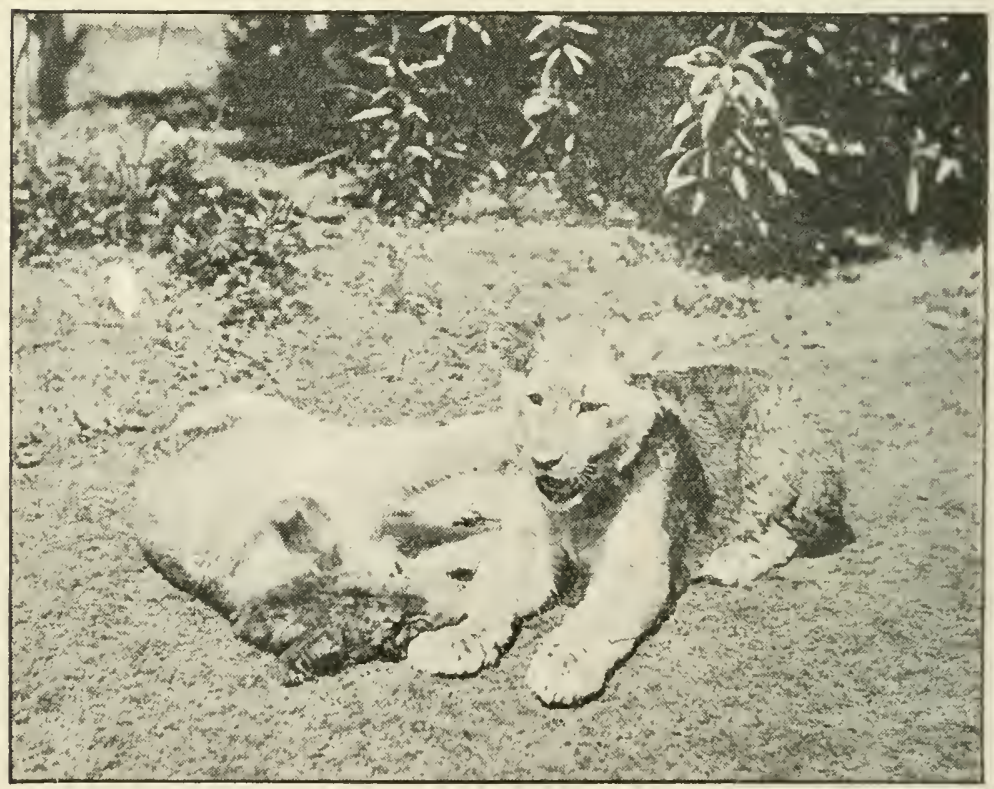

FIG. 21.-Six montks old Lions (the same as above). 
has lived in the gardens for sixteen years, being one of the pets of the staff. A few years ago her claws had grown into the pads of the feet, owing to the incessant walking on the concrete floors, and they had to be cut off and extracted. This operation was performed without chloroforming the animal, merely by putting her in a large crate and fastening up her legs with ropes. Tame as she was, she objected very much to the procedure and growled, spat, and snarled like a freshly caught animal. A fine pair of 3-year-old lions were obtained by purchase from the Belgian Congo in 1916. The female has given birth to two litters, the first of four (which she did not rear) and the second of three, by a fine Black-maned Somali Lion. It was then discovered that the mother had no milk for her offspring, so they were removed when only 18 hours old, and put on to a bull terrier bitch, who-with the subsequent aid of an old pointer bitch-successfully reared two of the cubs. Photographs of the cubs, aged 6 weeks and 6 months respectively, are appended.

Felis caffra. Cape Wild Cat. Wilde Fat or Vaal Boschiat. (Also called Wild Cat, or Caffre Cat, by the colonials.)

General coloration resembling that of the tam? "tabby" of the yellowish type-the ground colour varying from a speckled grey-brown to a greyish yellow, marked with more or less distinct dark horizontal stripes. Chin white. Back of the ears reddish brown. Limbs darlier than the body and ringed with black. Tail ringed towards the end with black and with a black tip. The littens are paler and yellower in tone than the adults, with the markings paler and less distinct. Length of head and body of adult, 2 feet. Tail, 9 to 10 inches.

The Wild Cat is fairly common throughout the wooded 
tracts of South Africa. It is nocturnal in habit, prowling about at night in search of food, and visiting poultry yards whenever it gets the chance. It lies asleep during the day in its lair in some reed bed, thicket or bush, where it also brings forth its young, varying from two to four or five in a litter. The usual number appears to be four. It lives chiefly upon rats, mice, and other rodents, and birds-especially the young of game birds.

It is a fierce and almost untameable animal, exhibiting but little fear of man. I remember some years ago coming suddenly upon a pair while shooting in the mimosa scrub, near Brandfort, Orange Free State, and they calmly stood and looked at me for a few seconds before leisurely galloping off into the bush. This animal often figured amongst the day's bag of a shooting party in the eucalyptus plantations north of Johannesburg, where it no doubt played havoc amongst the young guinea-fowl and francolin.

Mr. W. L. Sclater, in his " Mammals of South Africa," mentions the fact that some writers recognize two varieties in South Africa, and when I sent him some skins from Modderfontein, near Johannesburg, in 1904, he thought they might be those of $F$. chaus, the Indian Jungle Cat, or a closely allied species. The general tone was yellower than that of the Common IVild Cat, and the tail appeared to be shorter. The subject, however, requires further consideration before any definite conclusion can be arrived at. In captivity the Wild Cat remains a fierce, snarling creature. The littens are very difficult to rear in captivity, but latterly I have had more success by giving them more room for exercise, fresh air in plenty, and the natural earth as a floor for their cage instead of concrete or wooden floors.

The Zoo has had examples from Kleinpoort, Grahams- 
town, Norvals Pont, Port Elizabeth, and Three Sisters, in the Cape; Pretoria District, Rustenburg, Settlers, Nijlstroom, and Sabi in the Transvaal; and Bethelem, Orange Free State.

Felis nigripes. Blackfooted Cat. Klein Gerlelite Kat.

Smaller than the Kaftir Cat; and of a sandy or tawny colour, covered with round or oblong very dark brown or black spots. Ears slightly pointed, and of a speckly brown colour. Legs ringed with black: tail indistinctly ringed or spotted and tipped with black. The soles of the feet are quite black, hence its name.

This species is very distinct from the preceding, both in coloration and general appearance. In coloration it is more like the Serval, but is shorter on its legs, besides being a much smaller and more compactly built animal. Length of head and body, 20 inches. Tail, 6 inches (Sclater). The largest tbe Zoo has ever possessed (a fine example from Kimberley) measured 19 inches long, but the usual length seems to be about 16 inches.

It ranges from the Central Cape Colony to the Eastern Transvaal. It is not uncommon in the Pretoria District. We procured two half-grown young ones while shooting: at Jericho in the Bushveld in June, 1914-they were hiding from the dogs in a low thick bush, and were easily caught. The Gardens have had examples from the following localities: Kimberley, Wolvehoek, Elands River, and several other places in the Transvaal.

It is a very difficult animal to lieep alive in captivity, pining away and dying very suddenly. Old examples, when captured, only sulk and refuse to feed. It is also of a wild, retiring nature, and almost impossible to 
tame, spitting and snarling at one after many months. of captivity.

Leopardus pardus. Leopard. Lnipaard and Tijger.

(Sometimes "Tiger," of the colonials.)

The Leopard is almost as well known an animal in South Africa as the Lion, and its handsomely marked skin is much prized by Europeans and Blacks alike.

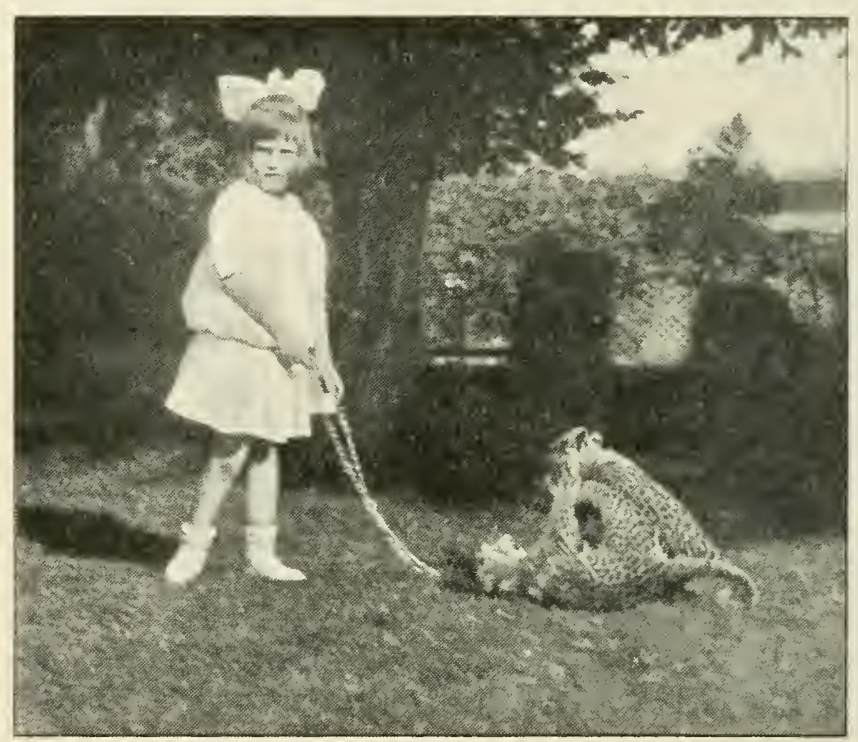

Fig. 22.-Baby Leopards at play.

The ground colour of the fur is of a yellowish shade, fading to white on the region of the belly, covered with dark brown or black spots, those on the back, sides and flanks being arranged so as to form incomplete rings. with light centres. The tail is ringed. Length of head and body from 3 feet 6 inches to 5 feet. Tail, 2 feet 6 inches to 3 feet. It is a shorter-legged, longer-bodied animal than the Cheetah, from which it is further distinguished by its "ringed" spots. The Leopard is found 
all over Africa, and also inhabits a large portion of India. In South Africa it is not uncommon in the more wooded localities; and is still fairly common in the Albany Division of Cape Province, where a dark or melanistic variety also occurs. The Zoo has had examples from India, Ceylon, Moçambique, Rhodesia, Pietersburg, Belfast, Sabi, and South-West Africa. The latter animals appear of a more sandy tone than those from the Union.

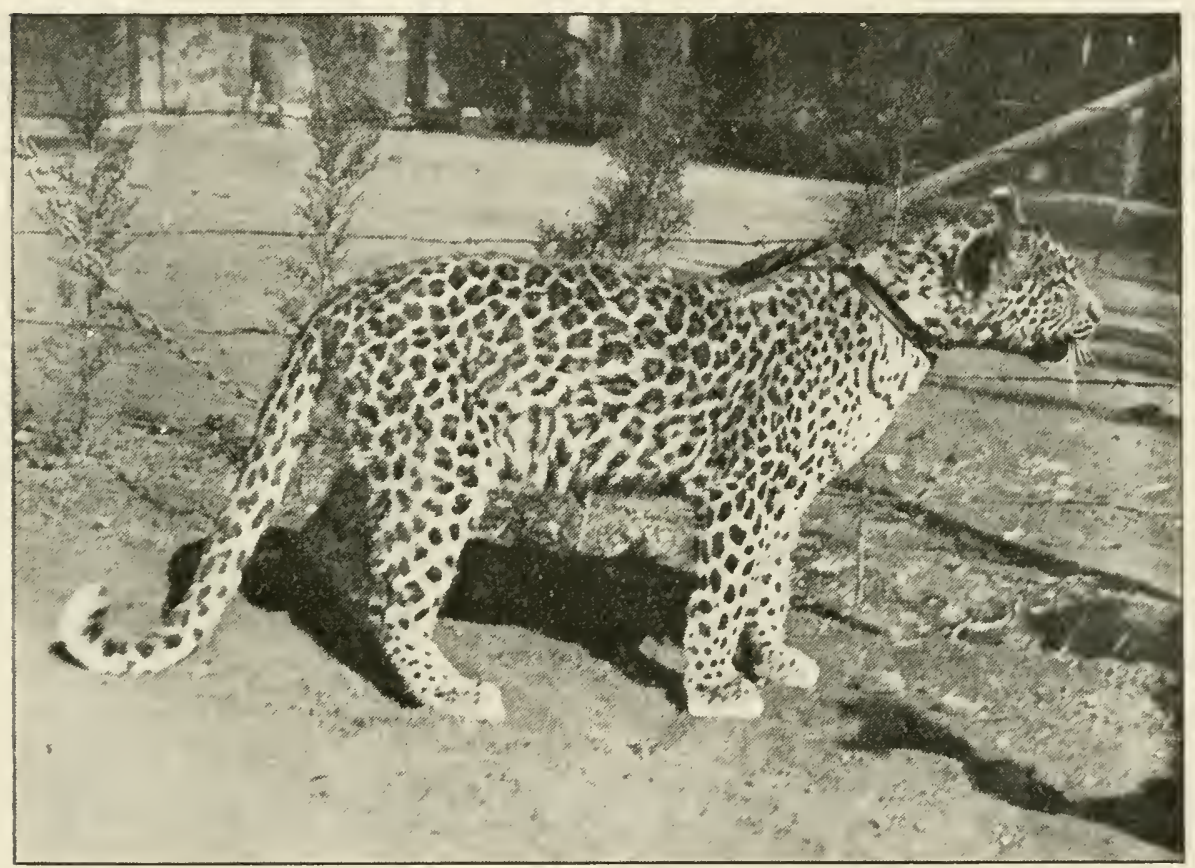

FIG. 23.-Young Leopard ("Nora").

The Leopard's favourite haunts are on rocky hillsides or amongst thick bush, but sometimes it may be found on rocky or stony kopjes, where there is little or no bush. It hunts singly or in pairs, and is more nocturnal in its habits than the lion. Its food chiefly consists of Dassies, Baboons, Monkeys, Cane-rats, Duikers, Bluebuclis, and other small Antelopes, and it will steal lambs, pigs and poultry from the farmyard. The Leopard is an active 
climber, and ascends large trees. We have seen one descending from a tree and sliding down the trunk as a cat would slide down a pole.

It gives birth in the spring to from three to six cubs, the former being the more usual number.

Although not to be trusted with as much confidence as a Lion, we have possessed one or two very tame examples, notably a female called "Nora," who lived in the gardens for three years, until she was viciously done to deathfor no accountable reason-by a male leopard. Up to the last she could be taken out of her cage and wallied about the grounds on a chain (when the public were absent).

Several litters have been born in the gardens, three being the usual number. The cubs are barely 6 inches long when born, and are blind and helpless. At six weeks they begin to play like kittens, and a prettier sight can hardly be imagined than a dozing leopard with her cubs gambolling around her. The period of gestation as observed here is from ninety-two to ninety-five days.

Zibethailurus seryal capensis. Serval. Tier (Tijger) Bosch-kat.

(Tiger Cat of the colonials.)

This animal is a higher, "leggier" looking animal than the common Wild Cat. It is of a reddish yellow ground colour, varying individually-some being darker and others lighter in shade-covered with solid black spots, which take the form of bands on the nape and sides of the neck and upper shoulder. Length of head and body about $2 \frac{1}{2}$ feet, tail 9 inches. A fine example in the Pretoria Zoo stands 18 inches high at the shoulders. 
The Serval ranges throughout the sub-continent, although nowhere common. It inhabits the reed-beds or thickets of bush, but prefers the neighbourhood of streams. It lives chiefly on small mammals and birds.

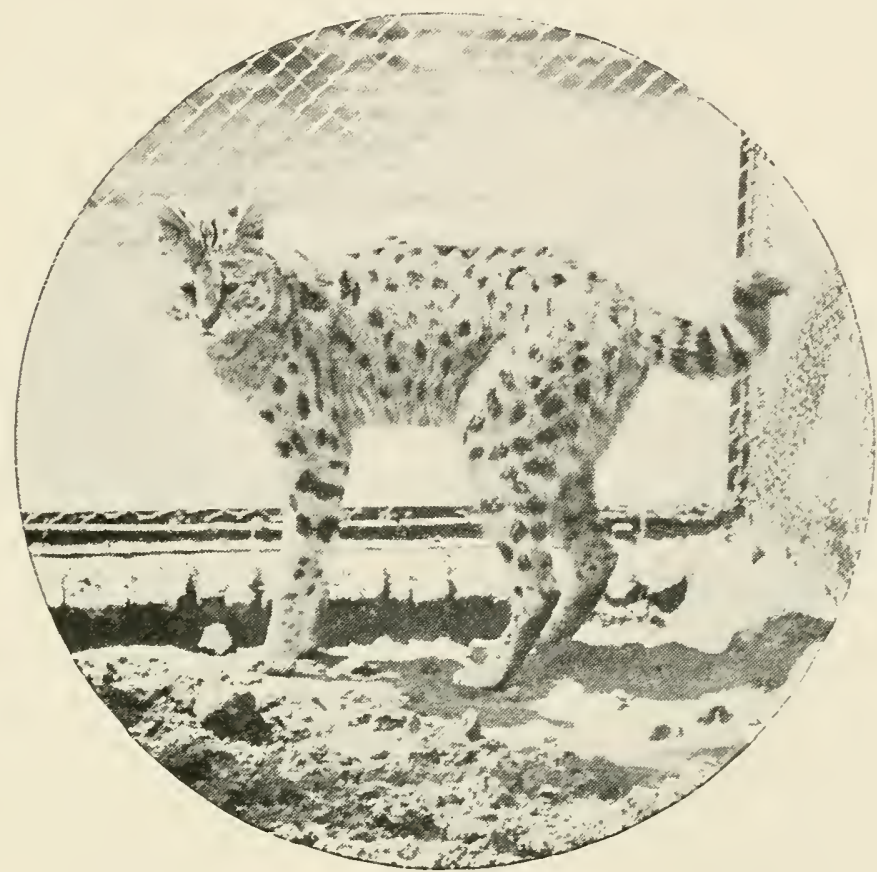

FIG. 24.-Serval, or Tiger Bush-cat.

The Zoo has had examples from Griqualand East, Sterkwater, Pisanghoek, and Rhodesia. A fine pair has been recently received from Barotseland-a present from His Excellency Lord Buxton.

Caracal nubica. South African Lynx. Rooikat.

(Caracal of the Natural Histories.)

This animal can at once be distinguished by its general reddish colour and pencilled ears. The chin, upper throat, and lower portion of the cheeks are white, while the tufts of long hair on the ears are black. The tail is short. 
and of the same colour as the body. Length of head and body about 3 feet. Tail, 1 foot.

This handsome creature is an inhabitant of the entire African continent, extending even to Arabia, Persia, and India, although the Caracal of the latter regions bear's a different sub-specific name.

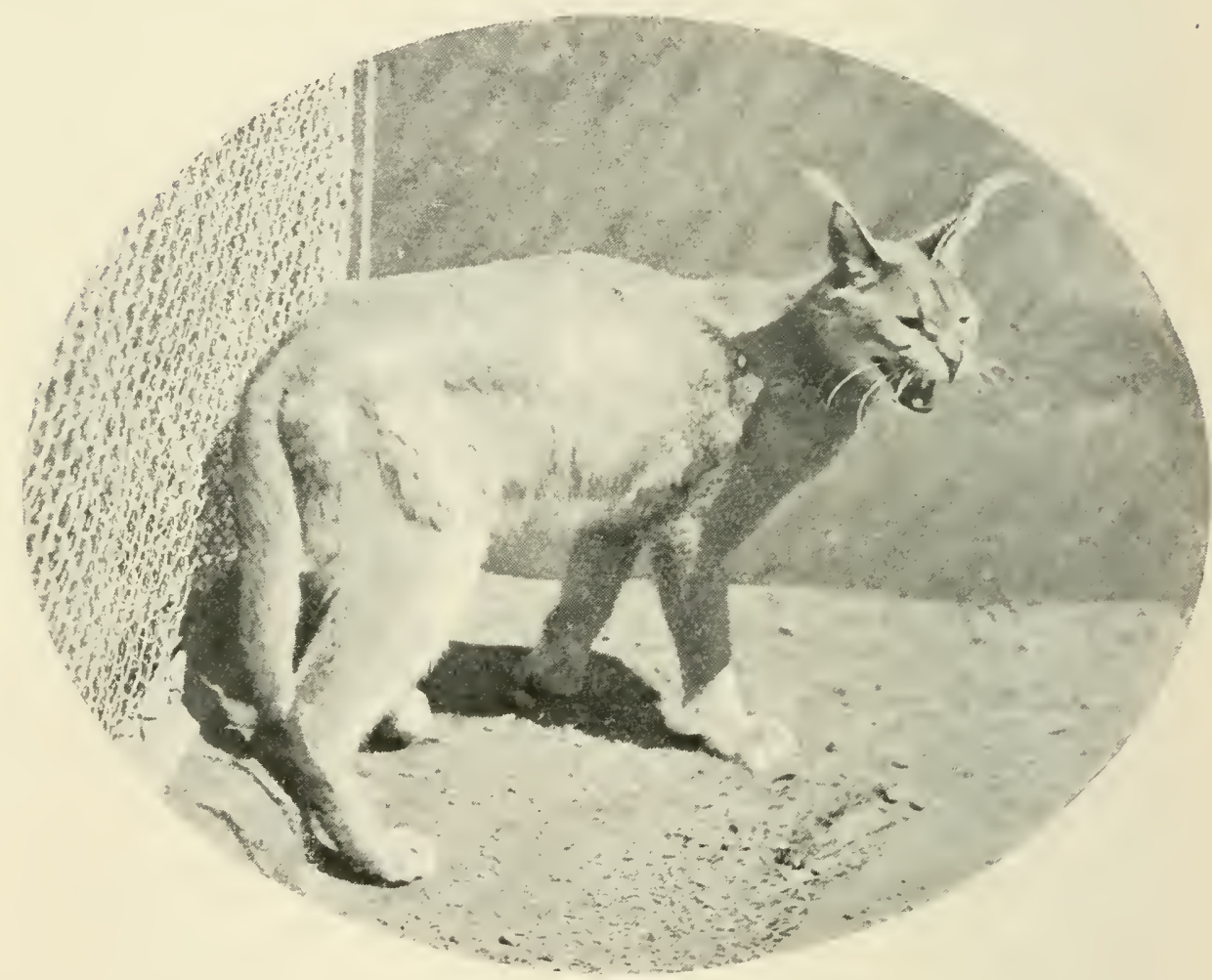

FIG. 25.-African Lynx, or Caracal.

We have found them not uncommon in the neighbourhood of Grahamstown, and in certain bushy tracts of the Orange Free State. The Zoo has obtained examples from Nafeking, Kimberley, Christiania, Van Rynsdorp, Griqualand, and Serowe. It preys upon small mammals and birds, especially game-birds and their young, and has been known to ravage sheep kraals. It is of a some- 
what fierce nature, and will even after some years of captivity growl and spit at the approach of anyone. We have, however, at present a female which has been handreared, and which is as tame as a house cat; it will come up to the bars of the cage when called, rubbing itself against the sides and purring loudly in a similar manner to the familiar "tabby." 


\section{Order PINNIPEDIA.}

A group of carnivorous animals specially adapted by Nature for an aquatic life, including the Walrus, Seals, and Sealions. The limbs are modified to form paddlelike or fin-like appendages termed "flippers," the digits of which are united by a membrane. Tail short.

\section{Family OTARIID.E.}

This family contains the Eared Seals, characterized by the possession of a small external ear, and by the structure of the hind limbs, which project forward, and so enable the animals to progress on land.

Arctocephalus capensis. The Cape Sealion. Zeclecurv. (Robbe or Seal of the Cape fishermán; Seadog or Seabear of the Natural Histories and Whalers.)

This animal is also called the Cape Fur Seal, although it is not a true seal at all. Captain Woodward, of Sealion fame, told me that he considered the Cape animal not nearly so intelligent as the Californian species; at any rate, when judged from the standpoint of the trainer.

In coloration it is of a rich dark brown, ruddier on the neck. Old males have a fairly well developed mane all round the neck. Length about 6 feet; tail, 3 inches.

It is an inbabitant of the sea, landing upon the small islands along the south and south-west coasts of South Africa to breed in the summer, when the females usually give birth to two young-or to shed their fur in winter. The skins form, on account of the fur, an article of 
commerce, fetching about 25.5. each on the London market.

The $/$ oo has possessed eight of these animals, living for nearly three years in this altitude, and in fresh water. 'They were fairly intelligent, coming when called, or at feeding time, jumping out of the water and clambering

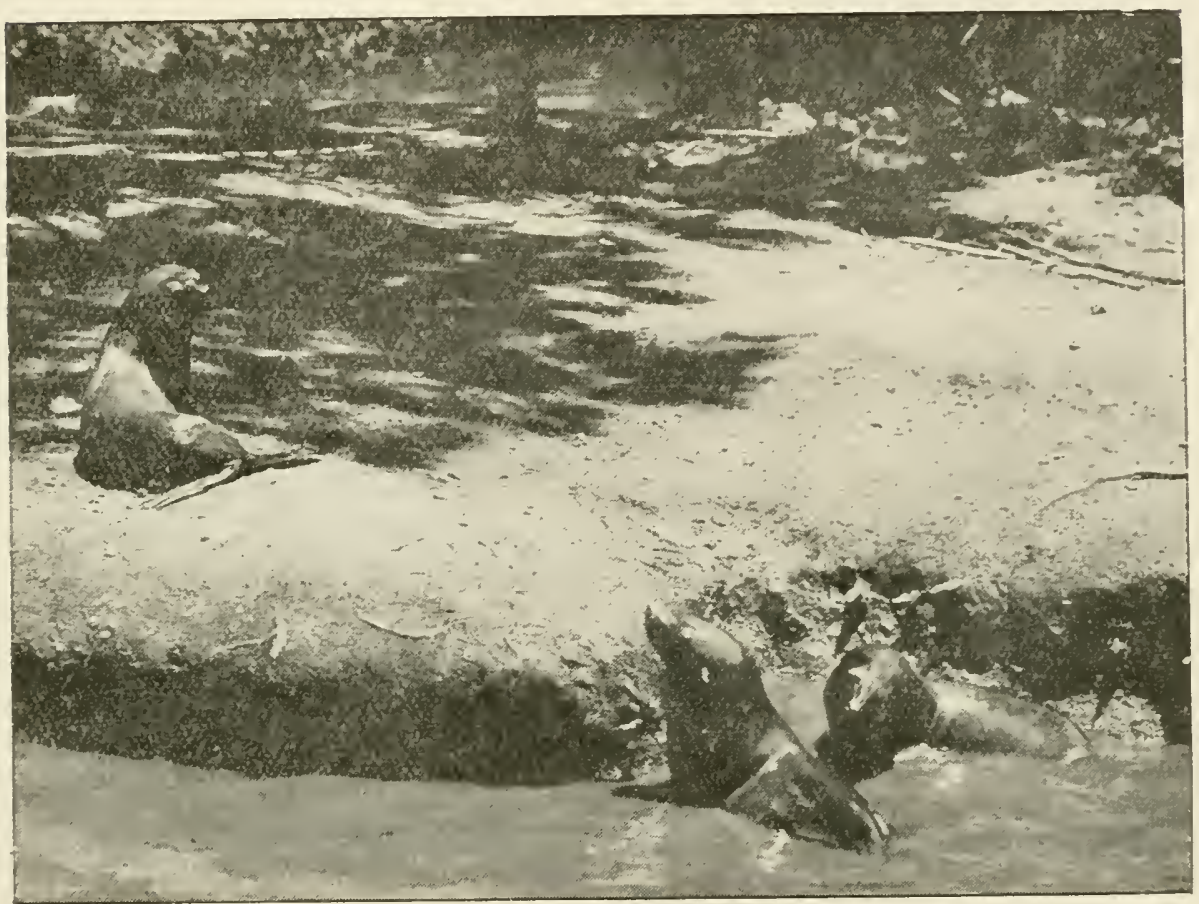

FIG. 26 - Cape Sealions.

up a rockery to dive off for their fish. Their speed in the water was wonderful to see, and as their tank is 100 feet long they could develop a good spurt. During the heat of the day they would lie on the water only half submerged, with the body in a peculiarly curved attitude, not making a movement, except to blink an eye or scratch themselves. They had voracious appetites, and would swallow 10 lb. of fish each, when given them, and then 
look for more. When we lost the last two through an accident-the one overbalanced itself from the top of the rockery, falling backwards and striking its head on the rocks at the edge of the water-they were only about three-quarters grown, so I presume full-grown animals would easily devour $20 \mathrm{lb}$. of fish per diem, if it was given to them.

\section{Family PHOCIDAs.}

\section{True or Earless Seals.}

The chief external character which distinguishes the members of this family from the eared Seals and Walruses, is the backwardly directed nature of the hind limbs, being more like a paddle or rudder. 'There is no external ear, and the front limbs are smaller than the hind ones, and have well developed claws. The under surfaces of the feet are covered with fur.

Macrorhinus leoninus. Elephant Seal or Sea Elephant. Zee-Olifant.

This Seal, which is the largest of the pinniped carnivora, takes its trivial name from the proboscis-like appendage on the nose of the male, which can be expanded at the will of the animal. The teeth are small, and the cheek teeth are of simple structure. There are no claws on the hind feet.

The colour is grey, with a blackish tinge, and is darker above than below; fur coarse and short. Length from 15 to 20 feet (males), 9 to 10 feet (females).

This seal formerly inhabited the islands of the South Atlantic, Pacific, and Indian Oceans, but is becoming scarcer and more restricted in range, owing to constant 
persecution. It was common on the Falliand Islands and 'Tristan da Cunha, but is now scarce on the former', and has entirely disappeared from the latter.

As one or two examples have been procured off Mozambique, I am including the species in my work. 'The Transvaal Museum contains the skeleton of one from Delagoa Bay. 


\section{Order RODENTIA.}

T'his is a large group containing the so-called "gnawing" animals, which are usually of small size and are characterized by the possession of chisel-like incisor teeth in both jaws, which are curved, rootless and extend far back into the jaws: these teeth grow throughout the life of the animal and are kept within bounds by the gnawing of wood, \&c. There are no canine teeth, and the premolars are reduced. Their feet are plantigrade or nearly so. Rodents are found all over the world, being commonest in South America, and scarcest in Madagascar and Australia. Most rodents are herbivorous, although some are carnivorous feeders. Typical rodents first made their appearance in the Upper and Lower Eocene periods. There are two sub-orders, the Simplicidentata (with only one pair of upper incisors) and the Duplicidentata (with six above and two below at birth; the outer pair of the former is soon lost, the second pair being considerably reduced in size, the third pair being large). The Simplicidentata are divided into three "tribes": the Sciuromorpha, containing the Squirrels and Beavers, the Myomorpha, with the Rats, Mice, Jerboas, Mole-rats, \&c., and the Hystricomorpha containing the Springhares, Porcupines, Agouties, Pacas, Cavies, \&c.

\section{Family SCIURIDA.}

This is a small family in South Africa, containing only four species of Squirrels. The skull possesses post-orbital processes, and the molars are tubercular and rooted. The premolars number two above and one below. 
Paraxerus cepapi. Iellow Squirrel. Ciele Eclihoorntje.

(irey-fosted Squivel of some authors.

General colour above of a grizzled yellowish colour, owing to the hairs being black at the bases, and with a subterminal black ring; below much paler-almost white. The ears are of moderate size and sparsely haired. The tail is bushy and of a darker appearance than the body, the yellow hairs bearing a double ring of black. Isength of head and body 6 inches, tail $6 \frac{1}{2}$ inches. This little squirrel is the commonest and most widely distributed of the few arboreal species in South Africa, and is found in the Pretoria and Rusteuburg bushveld, especially in the more wooded valleys of water-courses. It feeds upon the berries and seed-pods of various trees, principally the fruit of the "marula" when in season; and it descends to the ground in search of bulbous roots of various kinds. It is usually found singly or in pairs, and it can run up the perpendicular trunk of a tree with great ease and rapidity. I also met with this little animal at Serowe in Bechuanaland, and while strolling round near the magistrate's house there I saw several scampering over the ground, dashing from one tree to another; they appeared to be fairly tame. This species is said to inhabit the whole of Rhodesia-in fact the first examples the Zoo possessed came from Shesheke on the Zambesi Rivel -Damaraland and Nyasaland. It is a sprightly little creature in captivity, making for itself a round nest of grass, to which it retires for the hot part of the day, issuing forth to feed towards sunset. During the morning it climbs and runs about with rapidity, and will come up to be fed from the hand. A female in the collection gave birth to two young ones. When captured young it makes an interesting and tame little pet, but is not so easily tamed as either the Mierkat or Ground Squirrel. 
There are two other species found within our borders; of these the Red-headed Squirrel (Paraxerus palliatus) differs mainly from the previous animal by being of a rufous colour below, and ranging from Zululand in the east up through Mozambique and Nyasaland to Central East Africa. The Striped Squirrel (Paraxerus congicus) is browner above than either of the preceding species and can be immediately recognized by the two parallel stripes which run from the shoulder to the hind limbs: a pale yellow one above, below which there is a dark one. This is a West African form, coming as far south as Ovamboland in South West territory.

The American Grey Squirrel (Sciurus carolinensis) was introduced into Cape Town some years ago by the late Cecil Rhodes and has multiplied to such an extent that it has now overrun the Cape Peninsula and has become a pest in gardens and orchards

Geosciurus capensis. Ground Squirrel. Waaierstaart.

Although often called a Mierkat by the South Africans and especially by the Boers, this animal is, needless to say, not a Mierkat at all but a true rodent-a squirrel adapted by nature for a life on the ground instead of amongst the branches of trees, like its relations all over the world.

Above and on the sides it is of a pale red-brown, or greyish-brown colour slightly speckled with black, the hairs being short and bristly; a narrow white stripe runs from the shoulders to the haunches, and the underparts of the body are also white; eyes fairly large, but an ear conch is absent. The legs have four claws on the fore and five on the hind feet. Tail bushy, laterally flattened, greyish-with a pale line down the centre, darliening 
towards the tip, where the hairs are banded with black and white. The length of the head and body is 1 foot; the tail about 10 inches. 'I'he head is broad. The Ground Squirrel ranges from the central portions of the Cape Province (the Karroo-veld) northwards through the Orange Free State and the Bechuanaland Protectorate. It is purely a terrestrial animal, forming burrows or holes in the earth, where numbers live together in colonies or warrens; several may often be seen sitting up on their hind legs like Mierkats, watching with great interest and curiosity any passer-by. Should the intruder approach too closely, into their burrows they all scuttle, one or two, more venturesome than the rest, popping their heads out for a last peep. It has a peculiar habit of flashing the tail up and down (hence their Dutch name of "Waving-tail"), and has a weird whining shriek when alarmed. TVhen captured young this squirrel makes a tame and charming pet, running about the house with the freedom of a cat. It feeds chiefly upon bulbs, such as the "eentje" and the roots of rarious plants, grain and seeds. Numbers of these squirrels have been bred in the National Zoological Gardens and the quota of young at a birth apparently varies from two to sixfour being the usual number. 'They live well in captivity upon maize, sunflower seed, monkey-nuts (ground-nuts), acorns, \&c. The genus Geosciums with its single species is peculiar to the African continent.

\section{Family GLIRID.E:}

Dormice. Bos-staart Muisen or Žeren-slaper.

This is a group of small mouse-like animals with long bushy tails, slender forelimbs, and large ears and eyes. Their dentition is: 1 incisor above and 1 below, no canines, 1 premolar, and 3 molars above and below 
on either side -20 ; the incisor teeth are grooved. The Dormice are of arboreal habits and of a greyish colour: Trouessart, in his "Catalogus Mammalium," only mentions three species for South Africa, while

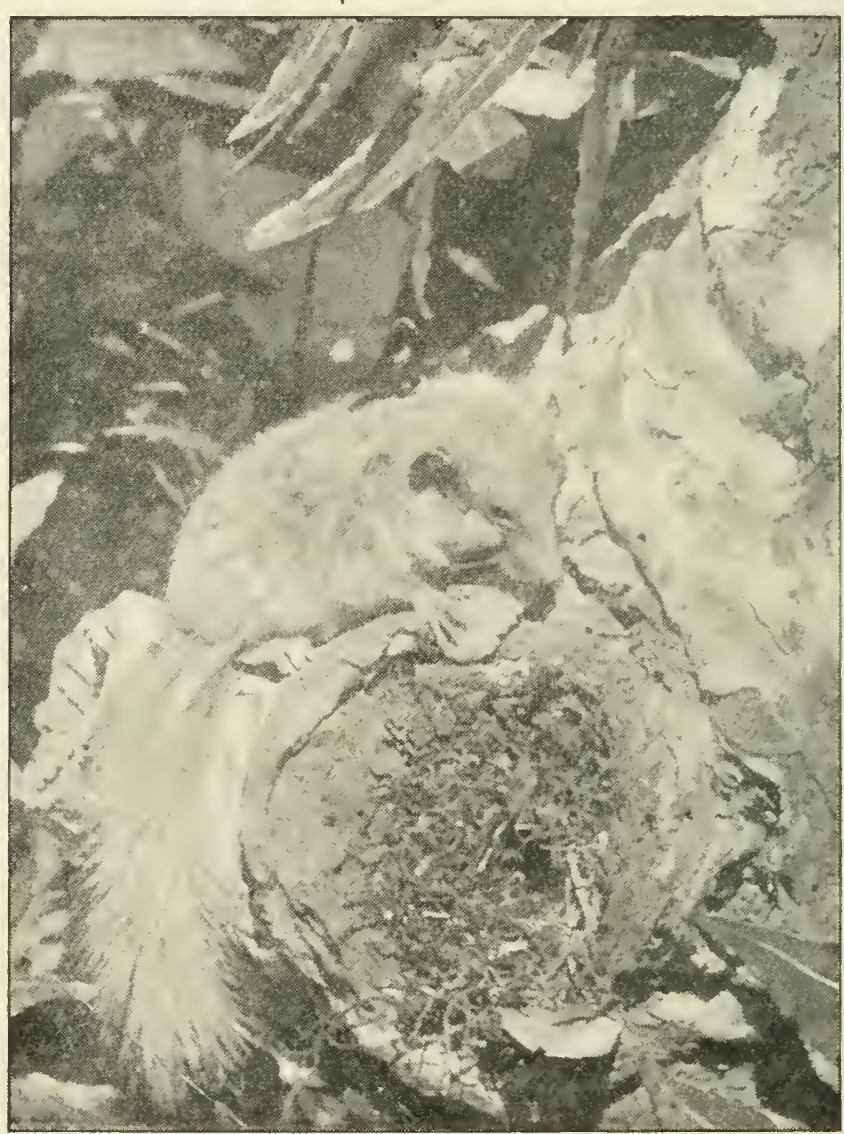

Fig. 27.-Cape Dormouse.

Mr. W. I. Sclater describes five in his "Fauna of South Africa : Mammals," vol. ii. Since the appearance of the latter work a few more species have been described, notably by Roberts of the Transvaal Museum, including Graphiurus pretoric, from Pretoria, and Graphiurus castwooda, from the Woodbush. The commoner species are :- 
Large Grey Dormouse (Graphiurus ocularis), measuring some 6 inches in length, with a tail of 4 inches with no white tip. 'This Dormouse is said to range all over Cape Colony, extending into Damaraland and the Central 'Iransvaal. It is easily distinguished by its prettily marked black-and-white head.

Cape Dormouse (Graphiurus murimus), measuring only slightly over 4 inches, and with a tail of $3 \frac{1}{2}$ inches, also without a white tip. It is found in the more wooded districts, ranging from East Africa southwards to Cape Colony, and is usually arboreal in habit, although it may be found in old stone walls, ic.

There are three more species inhabiting Rhodesia and South-West Africa which need not here concern us further.

These little animals live in holes or hollows in trees, under thatched roofs of houses or huts, or even in old stone walls, where they build a nest of grass or other suitable material. We have kept both species described above in the Pretoria Zoo, where the Cape Dormouse has even bred, bringing forth three naked and blind young ones in a rounded nest of tow and grass, built inside a small square box. They fed upon sunflower seeds, ground-nuts, bread and milk, sc. ; but insects and their larvæ, fruits, berries, and young shoots, \&c., form the bill of fare in the wild state. Like their European relations they hibernate during our cold months.

\section{Family MURID.T.}

Rats and Mice. Rotten en Muizen.

A family of small to medium-sized rodents, without premolars, a reduced pollex (first toe of the hind foot) and, with few exceptions, a sparsely haired tail. The skull is without post-orbital processes and has contracted 
frontal bones. The dentition is: incisors $1-1$, canines nil, premolar's nil, molars 3-3 on either side, making a total of 16 teeth.

There are a fair number of South African species referable to twelve genera, which I will not describe in great detail, owing to the fact that the smaller rodents are of a difticult group to work at, and require more than the average linowledge of anatomy possessed by the amateur zoologist or field naturalist.

\section{Genus TÁTERA.}

Gerbilles. Haarstacrt Muizen.

Rat-like in build with long hairy tails, pointed snouts and moderate ears only slightly hairy; the hind feet are long and possess four circular tarsal pads.

They reside in subterranean burrows and feed on seeds, roots, ic. Tronessart recognized four species, Tatera lobengula, Tatera afer, Tatera brantsi and Tatera paeba. The latter is of a reddish orange colour above and white below, whereas the first three are of a brownish fawnpaler or darker according to the species.

\section{Genus PACHYUROMYS.}

Closely allied to the true Gerbilles, but with much shorter tails and the tympanic bulla of the skull much swollen and enlarged. One species is found in Namaqualand, Damaraland and Bechuanaland (Pachyuromys auricularis), which is of a tawny brownish colour with a darker mottling of the thick short fur.

\section{Genus OTOMYS.}

\section{Water Rats, Tlei Rotten.}

Rat-like animals possessing short tails covered with scales and bristies. Ears generally large, and hind feet short. Trouessart recognized five species, but several 
more have been described since the last edition of his "Catalogus Mammalium."

'L'his genus contains the "Vlei" Rats, aninais abont a inches in length and of a dark brown colour, living in the marshy spruits and vleis, or in the scrubby bush localities of the veld.

In the Pretoria District the Brown Vlei Rat (Otomys imoratus) is found amongst the rushes and reed beds of the Aapies River (being fomd even within the precincts of the $/ / 20$ ), where it makes ruus or pathways for itself through the undergrowth, and subsists upon bulbs, roots, ic. It does not live very well in captivity, the majority soon getting a species of dysentery which speedily carries them off.

The other species are Otomys unisuicatus, Otomys brantsi, Otomys sloggetti and Otomys broomi.

Genus DENDROMYS. Tree Mice. Hoom MInizen.

This genus contains the small tree mice with long scaly tails sparsely covered with hairs. 'I'hey have slender legs and large ears. Four species are found in South Africa. There are two chestnut coloured species: a larger with usually, though not invariably, a black stripe down the centre of the back (Dendromys mesomelas), length $3 \frac{1}{2}$ inches, tail $3 \frac{1}{4}$ inches-ranging from Nyasaland to Cape Colony; and a smaller (Dendromys pumilio) scarcely 2 inches in length, with a tail of 2! inches, without a black dorsal stripe. Both species are whitish on the underparts. The Chestnut Tree Mouse (D. mesomelas) is fond of the reedbeds bordering watercourses, vleis, \&c., where they commandeer the nests of weaver birds wherein to bring forth their young. It may also be found in bushy localities, where it malies a nest for itself in the branches of a tree or bush. The 
Small Tree Mouse (D. pumilio) is similar in habits to the preceding species.

Both the above species have been liept in the Pretoria Yoo, where they lived fairly well upon bread and milk, bird seed, gran, \&c. There is a third species, the Grey Tree Mouse (Dendromys melanotis), easily distinguishable from the first two by its general greyish tiuge. It also possesses a black line down the centre of the back. Length of head and body, 23 inches; tail nearly 3 inches. It has so far only been recorded from the coastal tract from Cape T'own to Port Elizabeth and Durban.

Two genera-Steatomys, with one species (the shorttailed Fat-mouse), and Melothrix with two species of Mouse Gerbille-need not here concern us further.

Sub-Family MURINA.

This sub-family embraces the true rats and mice.

\section{Genus MUS.}

Nuzzle pointed, no cheek pouches. Eyes prominent. Tail more than half the length of the body and covered with scales, and generally also a few bristly hairs. 'The incisor teeth are not grooved and usually fairly narrow. This is a large genus, but so far only thirteen indigenous South African species are enumerated by Tronessart. To this were added a number recently described by 'I'homas and Schwann, and others. To this genus belongs the two domestic Rats-Black and the Brown (Mus rattus and $M$. decumanus) and the House-Mouse (MI. musculus), both of which have now overrun South Africa. The Black rat has become very common in Pretoria during recent years and together with its brown cousin has become a pest in the Zoo, although constant war is waged on them. 
'The commonest of the wild or indigenous species is perhaps the White-nosed Rat ( $M$. coucha) which I have located in the neighbourhood of Johannesburg and Nodderfontein, and in the Rustenburg and Pretoria districts. I procured it at Modderfontein anongst the mimosa scrub, where it constructed rums and burrows,

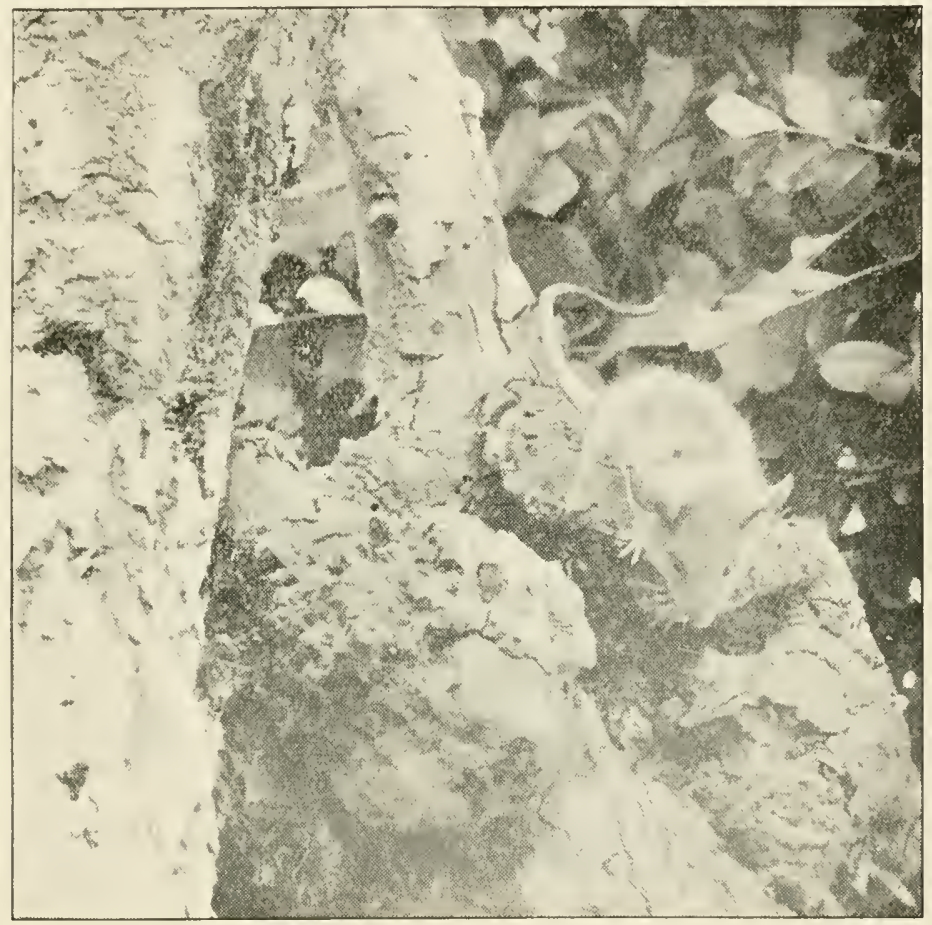

FIG, 28.-White-nosed Rat.

and in hollow antheaps on the veld not far from scrubby or reedy localities. Here a rounded nest of grass is made and the young brought forth and reared. 'This species has bred in the Pretoria Zoo, and three would appear to be the usual number of a litter. It feeds upon almost any vegetable matter, and in captivity is fond of sunflower seeds and bread and milk. It is of a dark slaty-brown above and dirty white below, with the tip of the nose and 
feet white. Tength of head and body $4 \frac{1}{2}$ inches; tail $3 \frac{3}{4}$ inches. This species has the widest range of any rat on the African continent, being found from Abyssinia and the Congo, southwards to Cape Colony.

The small Field Mouse (Mus mimutoides) (called by Oldfield Thomas and 'Tronessart (Leggada minutoides) is a small fawn-coloured nouse with white underparts. It measures some $2 \frac{1}{4}$ to $2 \frac{1}{2}$ inches in length, with the tail another 2 inches. I also took this little mouse at Modderfontein from hollow antheaps, where-like its larger congener, the White-nosed Rat-it makes a small domed or rounded nest of grass. It doubtless also makes nests amongst the cornfields and inealie lands where it is also found. A closely allied form, more chestnut in shade, inhabits the bushveld of the Central Transvaal. Mr. A: Roberts calls this Leggada deserti.

\section{Genus Cricetomys.}

Much like Mus in external characters; size large; cheek pouches present, for the storage of food.

\section{Cricetomys gambianus, Waterh.}

\section{Giant Rat. Reuzen Pot or Groot Rot.}

This animal looks like a large edition of the common Brown Rat. It has, however, dark speckles on the dorsal region and has a dark ring round the eye. The ears are oval and nearly naked. Edges of upper lip white; nose dark. Tail long and sparsely haired; the distal third being white. Length of head and body from 13 to 15 inches ; tail 15 to 17 inches.

This enormous Rat was first described from Gambia in West Africa, and has since been recorded from Central and East Africa, a number of sub-species having been 
described. Sclater records a pair in the South Africa Museum obtained by the late Captain H. F. Francis at Inhambane on the Mozambique coast.

The Zoo possesses two living examples received from Miss Olive and Master J. Stevens of Stonehenge Estate,

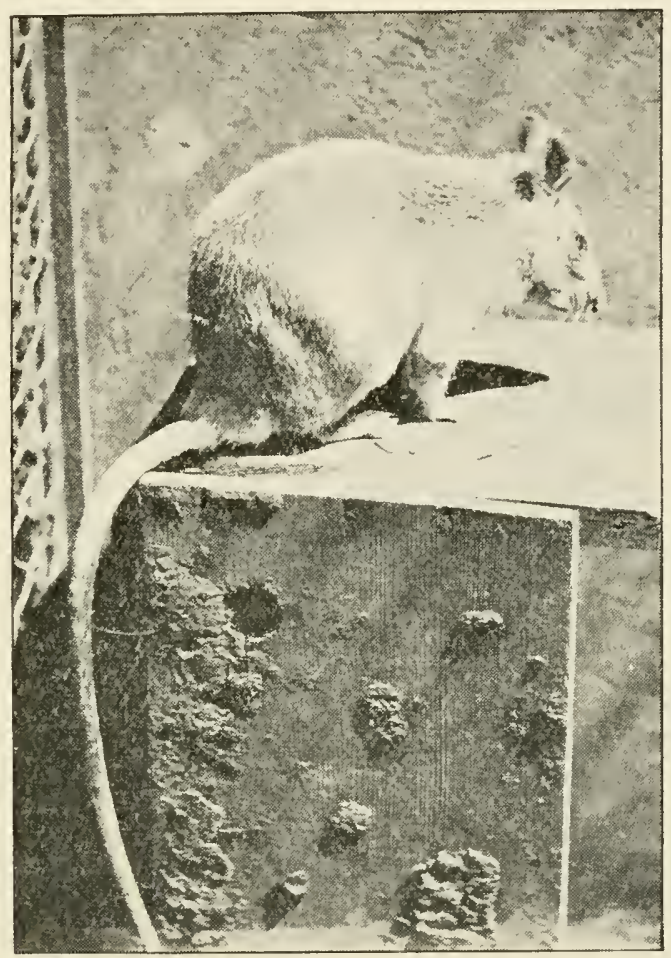

FIG. 29.-Giant Rat.

Louis 'Trichardt, Northern Transvaal, which brings the animal well within the Union of South Africa.

The sub-species is not yet clear and may even be new to science.

In captivity it eats much the same food as other rodents, and sleeps through the best part of the day, becoming active toward sundown. These examples measure, head and body, 15 inches ; tail, 16. 


\section{Genus EOSACCOMYS.}

There are four species of Pouched Rats, the commonest of which is Eosaccomys campestria. They are rat-like animals with cheek pouches and a short tail. They live in cultivated fields, making their burrows with an opening at both ends.

There are two other genera, Acomys and Dasymys, both of which are but little known.

\section{Genus ARVICANTHUS.}

Striped Ficld Mice. Gestrecpte Muizen.

Ears hairy. First and fifth digits sbort. The Striped Field Mouse (Arvicanthus pumilio) has been divided into a number of sub-species, the Bechuanaland form being larger and of a more sandy tone, while the Rhodesian is darker. The typical species has the body of a greyish brown colour with four longitudinal black stripes running down the back from the shoulders to the root of the tail. The length of the head and body varies from $33_{4}^{3}$ to 5 inches; tail from 4 to 6 inches.

The Striped Mouse is found in reedbeds or bushy patches near watercourses, or in bush country, although my personal experience has been invariably to find them on the banks of streams, vleis, \&c., where they make runs, like the Vlei Rats, and live upon vegetable matter of all kinds, even devouring human excreta. This Mouse has bred in the Pretoria Zoo, giving birth to two or three young ones at a time.

A second species (A.dorsalis) differs from the foregoing by the presence of only one stripe along the back. 


\section{Sub-family CRICETINA.}

\section{Genus MYSTROMYS.}

Fur soft and woolly. Ears large and broad. 'I'ail short. The White-tailed Mouse (Mystromys albipes $=$ albicaudatus) is brownish grey above and paler below, the tail, feet, nose, and chin being white. Body plump, hence its name of "Fat Mouse" sometimes used by authors. The $Z$ oo possessed a pair from a cave near Krugersdorp, presented by Dr. H. Lyster Jameson, which bred freely and reared a number of litters. Four appeared to be the usual number, and the young hung on to their mother's teats while she stalked about in a most unconcerned manner.

\section{Family BATHYERGIDE.}

Rodents with a short tail and legs, tiny eyes and no ear conch. They are adapted for an underground existence. 'Two genera inhabit South Africa. Bathyergus with the upper incisor teeth grooved; claws strong. Georychus with the upper incisors smooth; claws smaller.

Bathyergus maritimus (= suillus). Sand Mole. Zand Mol, and Duinmol.

Colour greyish, browner on the back. Fur thick and woolly. Head pointed, a bare flesh-coloured area round the nostril, and reaching the upper lip. Ear-conches absent, being mere circular apertures surrounded by bare skin. Legs short, claws strong and well developed for digging. The incisor teeth are white and prominent, the upper being also grooved; they are visible owing to their length and the shortness of the lips. Tail short and covered on the sides with white bristle-like hairs. Length of head and body from 12 to 16 inches; tail $1 \frac{1}{4}$ inches. 
'I'his animal is found in the sand-dunes and flats along the coast where it forms burrows. It ranges from Namaqualand past the Cape Peninsula to Knysna and is not found inland. It feeds upon vegetable matter, especially bulbs and roots.

\section{Genus GEORYCHUS.}

Resembling the previous genus, but the claws much smaller.

\section{Georychus capensis. Star Sand-Mole. Blesmol.}

Colour brownish or red-brown above, paler on the sides and greyish below. Head darker. On the top of the head and round the face a series of pure white spots. Head short and blunt in shape; the eyes very small. No external ear. 'Tail short, thick, and covered with white bristles. Incisors white and smooth. Length of head and body 8 to 9 inches, tail $\frac{3}{4}$ inch. It ranges from the Western Cape Colony to Southern Bechuanaland in the north and Natal in the east. The Blesmol burrows like the common Sandmole, throwing up mounds of earth at intervals. It lives on bulbs and roots, and is very fond of potatoes when these are available.

Georychus hottentotus. Mole Rat. Bruin Mol.

Colour similar to the preceding, slightly darker above. Size much smaller, length of head and body only $5 \frac{1}{2}$ in. No sign of white on the bead.

This is the common species of the eastern and northern districts, ranging from the Eastern Cape Colony and Natal through the Orange Free State and Iransvaa!

There are three other less linown species, G. damar- 
ensis, C.durlingi, and G. nimrodi, besides a number of recently created new forms of more or less validity.

Sand-moles are destructive to the agriculturist, as they are fond of potatoes, sweet potatoes, and roots of various kinds.

Family PEDE'TIDA.

\section{Genus PEDETES.}

This animal is kangaroo-like in form, with short forelimbs, and long well-developed hind legs, enabling it to jump long distances. There are powerful claws on the forelegs, which are formed for digging. Dentition: incisors $1-1$, canines $0-0$, premolars $1-1$, molars $2-3=20$.

Pedetes caffer. Springhare, or Cape Jumping Hare.

Springhaas.

Colour yellowish or sandy brown above, paler along the sides, and whitish below. The ears are long and pointed. The tail is strongly tipped with black. Hind feet with only four toes armed with straight, nail-like claws. Length of head and body about 2 feet. 'Tail about 1 feet 9 inches. This peculiar animal is found throughout the higher and dryer regious of South Africa, where it lives in colonies, forming deep burrows in the earth. It feeds, after sunset, upon roots, bulbs, and green vegetation. Its flesh is white and palatable, although many people will not eat it in South Africa, owing to prejudice. A favourite method of hunting the animal is with a bull's-eye or acetelyene lantern at night, the animal being blinded or fascinated by the light, at which it sits and stares-or may be it does so from curiosity; the eyes gleam like coals of fire and offer an easy mark to the sportsman. It progresses by leaps and bounds, after the 
manner of a kangaroo, but it can also crawl along in a more leisurely manner. When captured young it becomes very tame and makes an interesting pet. The natives catch them by means of a horsehair or wire noose set in the mouth of the burrow. It is a destructive animal in cultivated lands, devouring the growing crops. Captive specimens have shown a partiality to oats. It chews with rapidity.

\section{Family OCTODONTID.E.}

\section{(Ctenodactylidæ.)}

All four limbs provided with five claws. Clavicles imperfect.

Petromys typicus. Rock Rat. Nolii liot.

Colour grey brown or slaty, the hinder part of the back and point of the muzzle bright chestnut. Below dirty white. Whiskers long and black. Tail slightly shorter than head and body and covered by long black hairs. Length of head and bodv $5 \frac{3}{4}$ inches. Tail $5 \frac{1}{2}$ inches.

Dentition: Incisors 1-1, canines 0-0, premolars 1-1, molars $3-3=20$. This animal has so far only been found in the rocky mountains of Namaqualand.

Thryonomys swinderianus. Cane Rat. Tilet Rot.

This is a stout, rat-like animal with a short tail and bristly fur of a speckled yellow and brown colour above; paler below. It is the largest rodent in South Africa (excluding the Porcupine), being from 12 to 20 inches in length, with a tail of 6 to 7 inches. It ranges from the Eastern Cape Colony through Natal and the Eastem 'I'ransvaal, northwards to the Congo and East Africa. It 
inhabits the cane thickets or reed beds, forming lairs in the long grass or rushes, and feeding upon various roots, bulbs and other vegetable matter. It swims well and will take to the water when pursued. It lives fairly well in captivity, and will breed if given suitable accommoda-

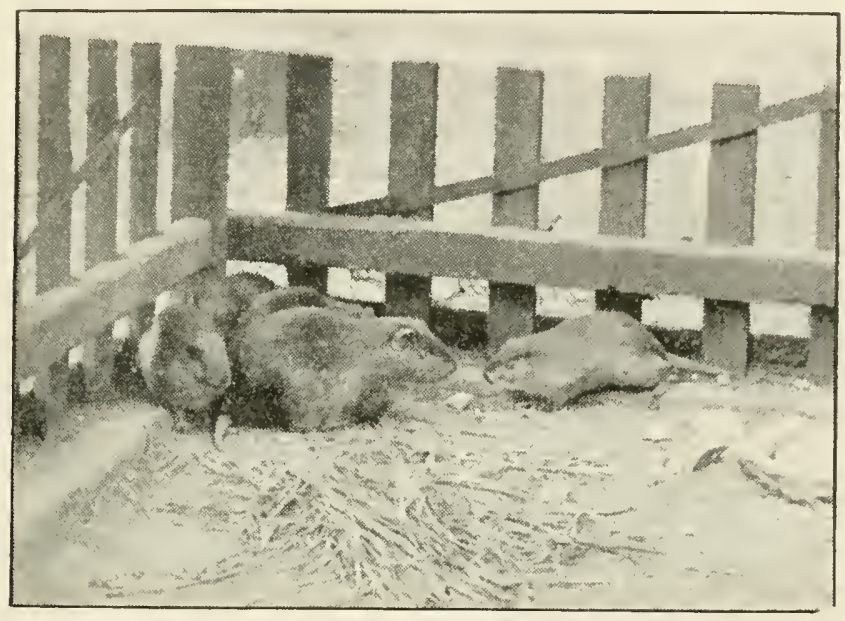

Fig. 30.-Cane Rats.

tion. It is fond of sugar-cane and is said to do considerable damage to the plantations in Natal and Zululand. The natives are fond of the flesh and hunt the animal with dogs; they also snare them in wooden traps. When down at Hectorspruit in the Eastern 'I'ransvaal last June, our dogs killed one half way up a rocky hillside, a peculiar locality for a Cane Rat.

\section{Family HYS'TRICIDE.}

\section{Genus HYSTRIX.}

Body covered with quills. Tail short. Dentition similar to the preceding genus, the number of teeth being the same, but the molars are semi-rooted. 
Hystrix africæ-australis. South African Porcupine. Ijzer.vark.

Colour dark brownish-black, the fore and under parts of the body being covered with long bristly hair; on the rest of the upper portion the bristles become modified into the true quills, which are stiff, sharp, and banded with dark brown and white. Length of head and body 2 feet, tail about 5 inches.

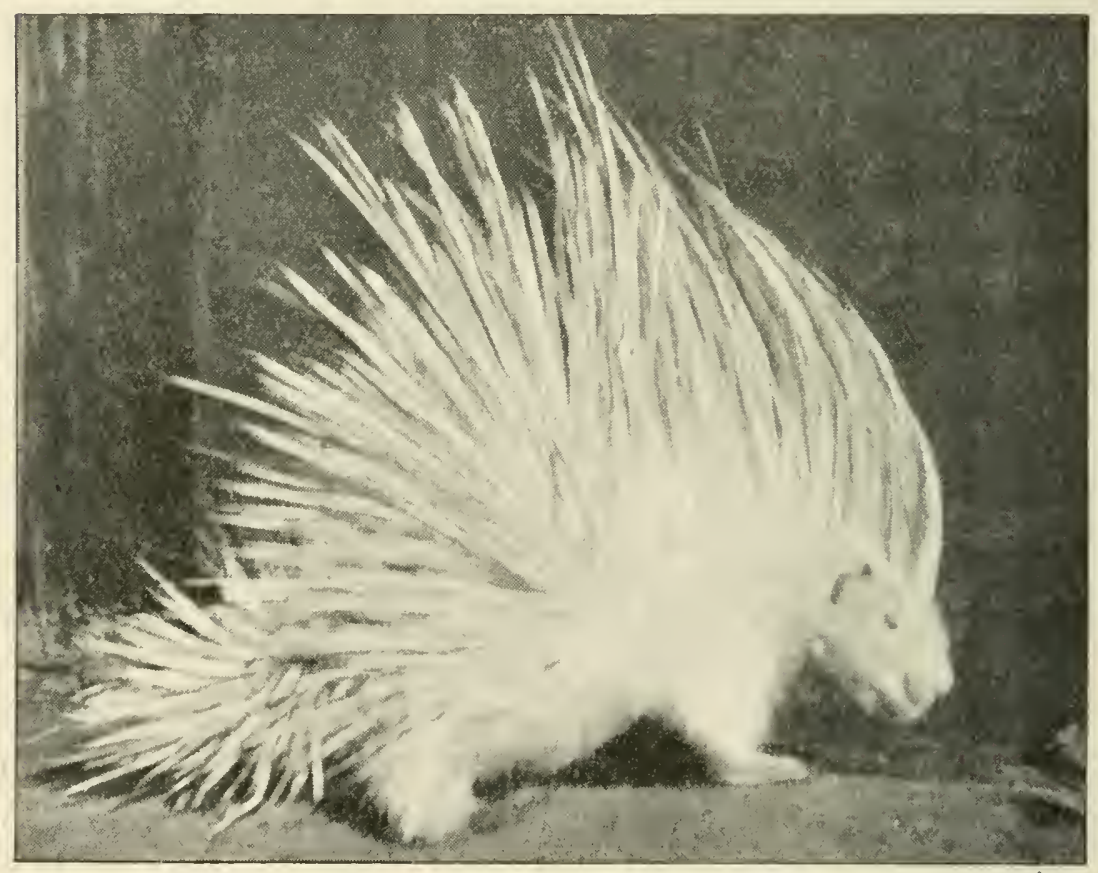

FIg. 31.- Albino Porcupine.

The Porcupine is found all over Southern Africa. It is nocturnal in habits, coming out at night to feed, although this is not the case with animals in captivity, who come out at all hours and will feed before sunset. They are reported as good eating by those who have tried it, but as they are very often infested with fleas and ticks, I have never brought myself to attempt the delicacy. 
A pair in the Pretoria $/ /$ oo have regularly given birth to two litters a year, the number being two at a birth, with the exception of two occasions-once when three were born and again only one young one. 'The third young one of the litter was not reared however. The male is a good father, and if any interference with his family is attempted

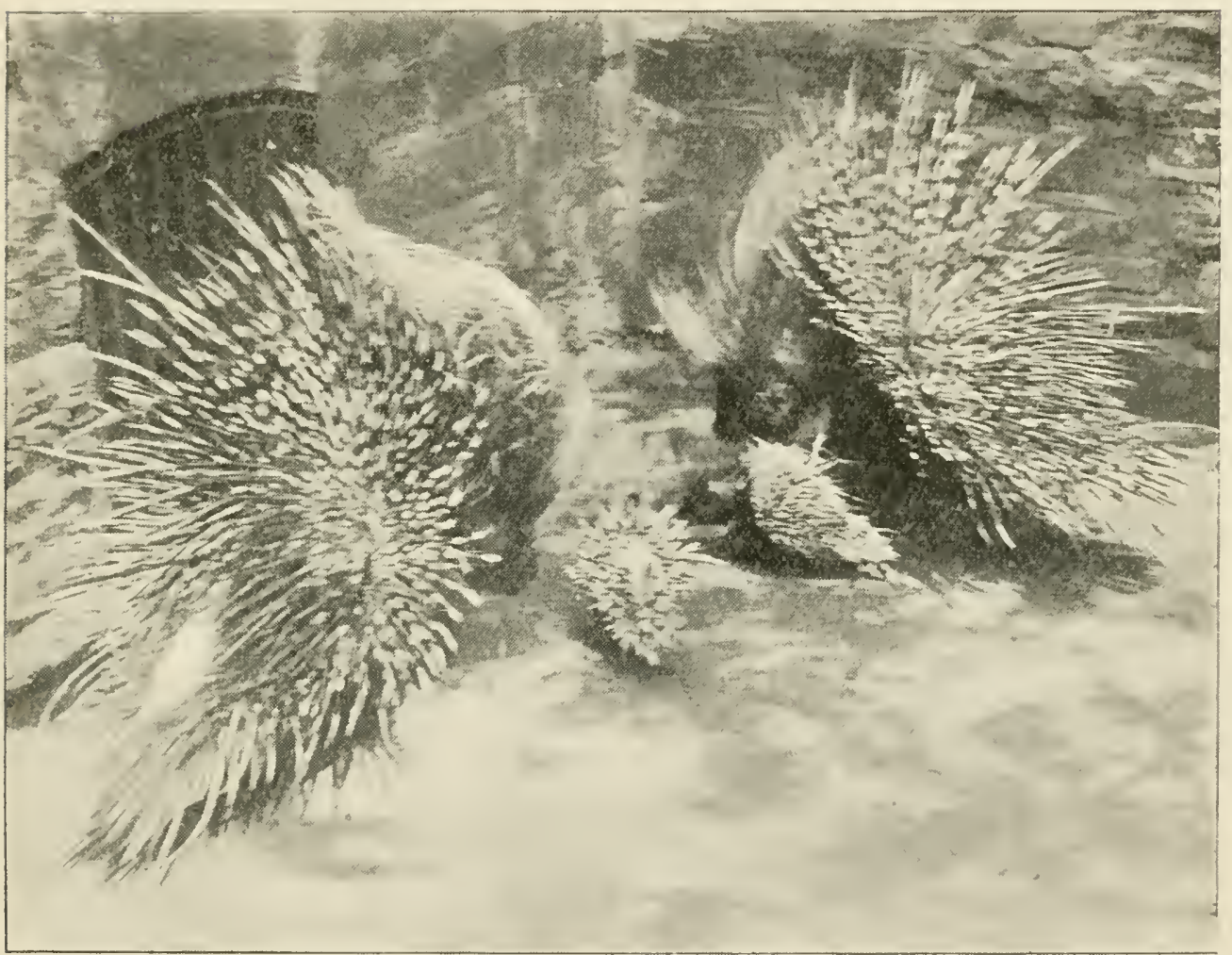

FIg. 32.-Porcupines and Young.

he will fly out of his house and approach sideways, rattling his quills in a threatening manner, the sound somewhat resembling a motor car being started up. 'The young when born are about the size of a three-quarter grown hedgehog, the quills being about three-quarters of an inch long and quite soft. 


\section{Family LEPORID王.}

\section{Genus LEPUS.}

Ears and hind legs, long. Fore legs medium. Tail short and bushy. Five toes to the fore and four to the hind legs. Dentition: incisors at birth 3-1, afterwards $2-1$; canines $0-0$; premolars $3-2$; molars $: 3-3=28$.

The Thick-tailed Hares have been separated into a new genus, Pronolagus, by Thomas and Schwann (Trouessart in his "Catalogus Mammalium" includes them under the genus "Oryctolagus"), chiefly upon anatomical characters, which need not further concern the readers of this book, except that the ears are shorter and the body more compact and rabbit-like.

Pronolagus crassicaudatus. Cape Rabbit. Kaapse Konijn or Rooi-haas.

Fur thicker and softer than in the succeeding species, speckly yellowish brown and black, giving a brownish hue to the upper parts, and reddish white below. Chin white; a black stripe on the cheek on either side of the face. Ears of moderate size and rounded at the edges. At the back of the head and neck a reddish patch. The legs are red-brown and the tail, which is short and bushy, is of the same colour, with no trace of black or white, so characteristic of the other species of South African Hares. Length of head and body 20 inches, tail $3 ?$ inches

This Rabbit is only found in rocky hills or kranzes, and is fairly well distributed over the sub-continent. It lives in pairs or colonies amongst the rocks. I found it fairly common in the hills around "Orange Grove" to the north of Johannesburg. The young-one or twoare brought forth in a well-developed state, well covered with fur, differing in this respect from tame Rabbits. I 
have captured several on the rocky hillside to the north of the Zoo, and one female so caught gave birth in captivity to one young one, but did not survive the birth of her youngster. A second species, C. ruddi, was described by Thomas and Schwann in 1905 from Sibudeni in Zululand, which has a redder tail and browner nape spot.

\section{Lepus capensis. Cape Hare. Vlak Hacas.}

General colour yellowish grey brown, mottled with darker owing to the woolly hair being slate colour at the base and tips yellowish or dun-brown with a subterminal black band; the sides are ruddier and the underside whitish. The back of the neck and head is grey. Ears about 4.1 inches long; tail 4 inches in length and black above, white below. Length of head and body from 20 to 24 inches.

This Hare ranges all over Cape Colony, Natal and the Orange Free State, and is found on the plains or amongst scattered scrub or bush. It feeds at early morn and towards sunset. It makes a "form" or lair in a tuft of grass or under a small bush or weed, although when pursued it will take to an Aardvark or Nierkat hole. Its speed is not as poor as the natural histories want to make out, as the writer has often had excellent sport with greyhounds on the Free State flats. We have shot females with a well-developed foetus towards the end of July and beginning of August, so that late winter or early spring seems to be the breeding season, and two the usual number at a birth. A highveld species, Lepus ochropus, is distinguished from the above by its yellow throat and nape.

A new species, Lepus monticularis, was described from Deelfontein in the Cape Colony. 
Lepus saxatilis. Bush Hare. Fol Haas.

This animal is called the Rock Hare by Sclater, and although it is found in stony kopjes in some localitieslike its relative the Vlak Haas - it is essentially a bushloving and bush-frequenting species. It is larger than the Cape Hare and differs further from this species by the fact that there is a rufous patch behind the neck on the nape, by its relatively longer ears (length $5 \frac{1}{2}$ inches) and legs, and by a white spot on the forehead, which is, however, not always present or conspicuous. Isength of head and body from 24 to 27 inches. T'ail 4 inches. It is found amongst the hills or bush from the Central Cape Province northwards. It is quite common amongst the eucalyptus plantations on the Rand, and I have found it plentiful amongst the mimosa scrub in the valleys and at the foot of the Free State hills, and in the Pretoria bushveld, where it is more common in the scattered thorn bush with fair undergrowth than in the more heavily timbered tracts. It is a good runner and makes excellent eating. It resembles the Vlak Haas in the fact that the number of young at a birth appears to be two. Like the preceding species it makes a lair in a tuft of grass or in a small thick bush, where it lies very close until disturbed. I have seen a pointer "stand" on a Kol Haas in its "form" for fully five minutes, when the hare had to be kicked out of its hiding place, from almost under the dog's nose.

A new form with smaller ears was described by Thomas and Schwann under the name of zuluensis. 


\section{Order HYRACOIDEA.}

This small order comprises the Rock Rabbits or Coneys -small rodent-like animals with hoof-like nails to the feet (excepting the second digit of the fore feet, which is furnished with a curved claw). These little animals have been classified with the rodents and also with the ungulata (or hoofed animals). They are certainly not rodents according to their dentition, and have not much in common with the ungulata, so we prefer to follow Huxley in his separation of them into a different order.

The number of teeth are: incisors 1-2, canines 1-0, premolars 4-4, molars 3-3-the milk teeth differing in that there are 3 incisors above and 2 below. There are no clavicles. Certain other important internal anatomical characters need not concern us in a work of this nature. The ears are small, the fur is thick and the snout is "split." Tail reduced.

There is only one living family, Procavida, with one genus, Procavia (Hyrax of Hermann), containing three South African species.

Procavia capensis. Rock Rabbit. Dassie, or Klip Das.

Colour a warm, speckly grey-brown, dartier in the centre of the back, with pale yellowish eyebrows. T'he soles of the feet are naked and black in colour. Length of head and body 18 inches.

'I'his little animal inhabits the rocky lirantzes or cliffs and hills, where it lives in colonies amongst the cracks or crevices, basking in the sun during the heat of the day and feeding upon vegetable matter, such as leaves, roots, 
bulbs, \&c., in the evenings and early mornings. Its flesh is edible, but according to some is not very palatable. When captured young and tamed it becomes an interesting pet, but is of an aggressive nature where other animals are concerned. A pair in the $/$ oo attacked a Roe Deer Stag and bit it so badly in the hip and forequarters that it eventually died, the tendons being severely injured.

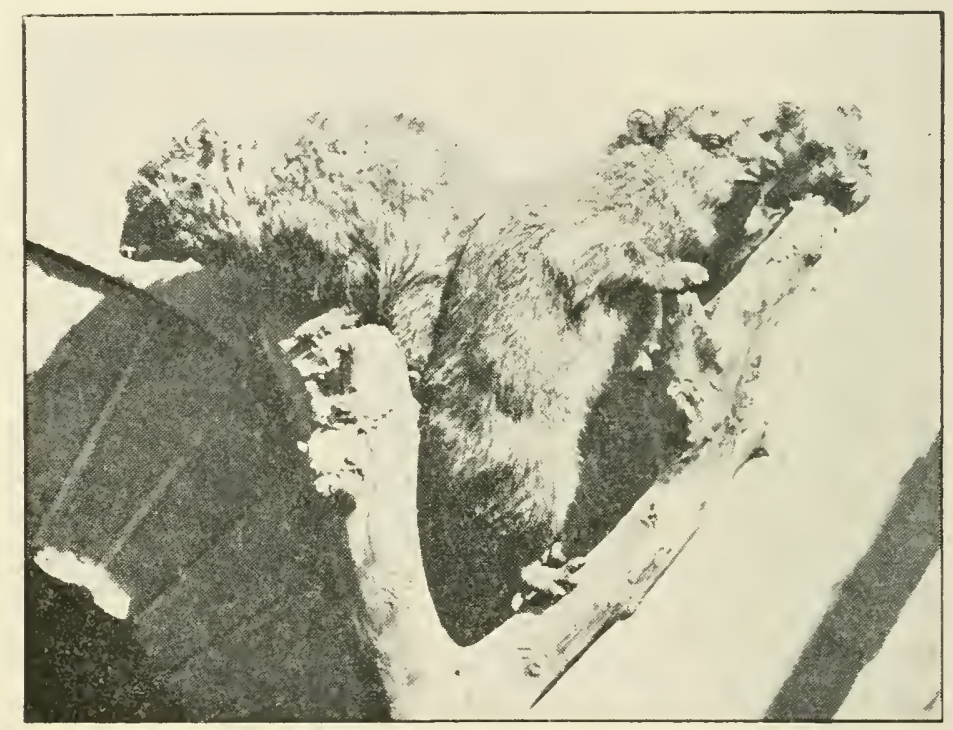

FIG. 33.- Rock Rabbits, or Dassies.

The bite of a Rock Rabbit is severe, as the little creature has strong teeth and powerful jaws, with which it can hold on with a grip like a vice.

From one to two young ones are born at a time, the latter being the usual number. These are active from shortly after birth.

Procavia brucei. Bruce's Rock Rabbit. Grijse Dassie.

General colour a grizzly grey-the hairs being slate colour at the base and ringed with yellow, black and white-under surface, including the insides of the legs, 
pure white. The spot in the middle of the back is yellow; this alone distinguishing it from the two other species. It is found from Central Rhodesia through Nyasaland and Mozambique to Abysinia.

Procavia arborea. Tree Rock Tiabbit. Boom Lassie.

Coloration resembling that of the previous species, but more grizzled, owing to the brown fur being tipped with light grey; the spot in the centre of the back is pure white instead of black or yellowish, and the ears are margined with white hairs. Length of head and body 16 to 18 inches. It ranges from Eastern Cape Colony through Natal to the Northern Transvaal, and possibly Southern Rhodesia. It inhabits hollow trees, running along the branches with ease and speed, but is also found amongst the rocks. The Zoo has had examples from the Woodbush in the Northern Transvaal. 


\section{Order PROBOSCIDEA.}

This order contains besides the Mammoth, the Mastodon, the Dinotherim and other extinct forms, the two existing species of Elephant-the Indian and the

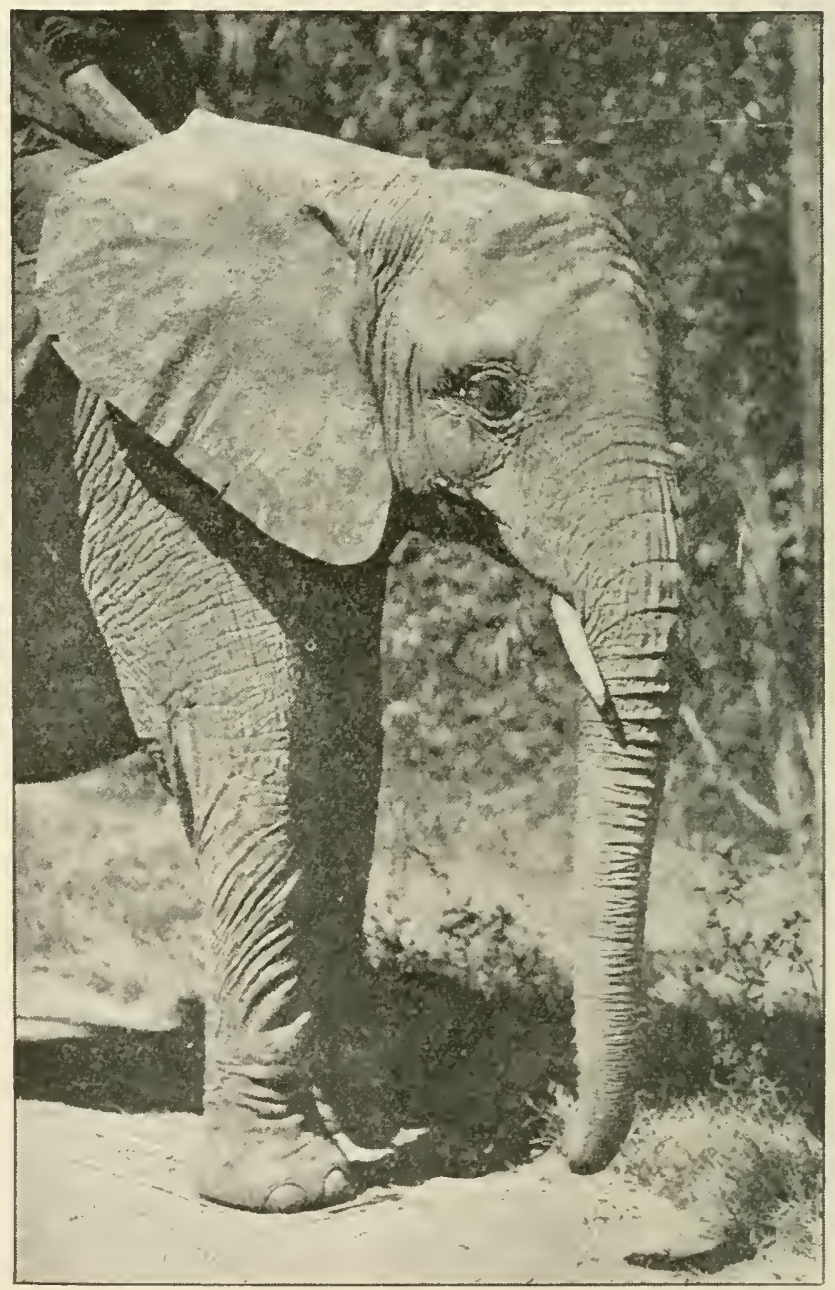

FIG. 31.-Head of African Elephant.

African. 'The latter', has, however', in recent times been subdivided into a number of local races or sub-species, whereof the Cape animal is a separate variety. The 
leading characteristics are that they are large pachyderms with a long "trunk" or proboscis, which is prehensile and serves the animal in lieu of an arm and hand; incisor teeth in the form of tusks situated in the mandible or premaxillæe, and large grinding teeth or molars, with transverse ridges. Canine teeth are absent. The legs are not bent at the knee and elbow, which is the reason for the peculiar walk of the Elephant. The

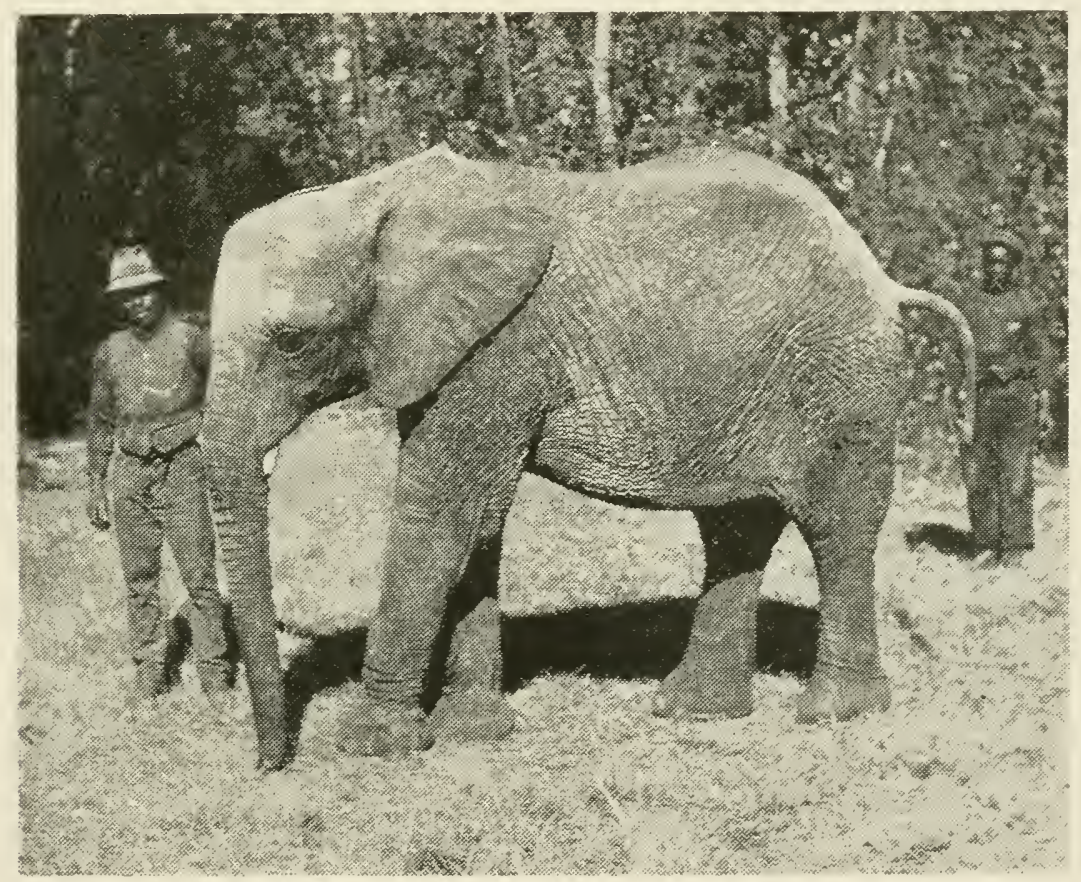

Fig. 35.-Young African Elephant (ahout 9 years old).

nails (five in number) are short and hoof-like and the body is very sparsely haired. There are no clavicles and the brain is fairly primitive and deeply set. The stomach is simple. The mammæ are thoracic and two in number.

Elephas africanus. African Elephant. Afritiaanse Olifant.

The African Elephant differs principally from its Indian brother in the enormous size of the ears, the shape of the forehead, which is convex (in opposition to 


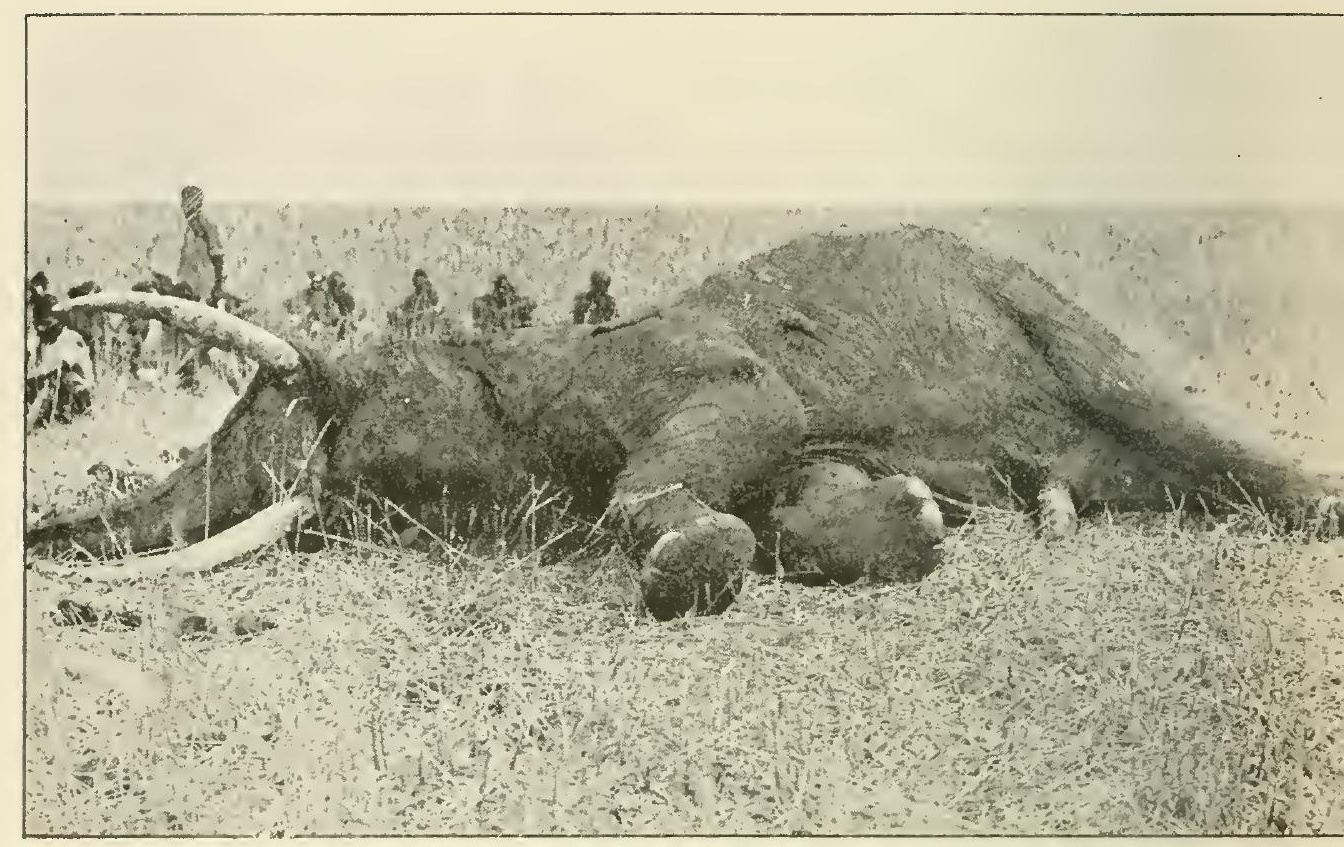

FIG. 36.-The Fallen Monarch (Bull Elephant).

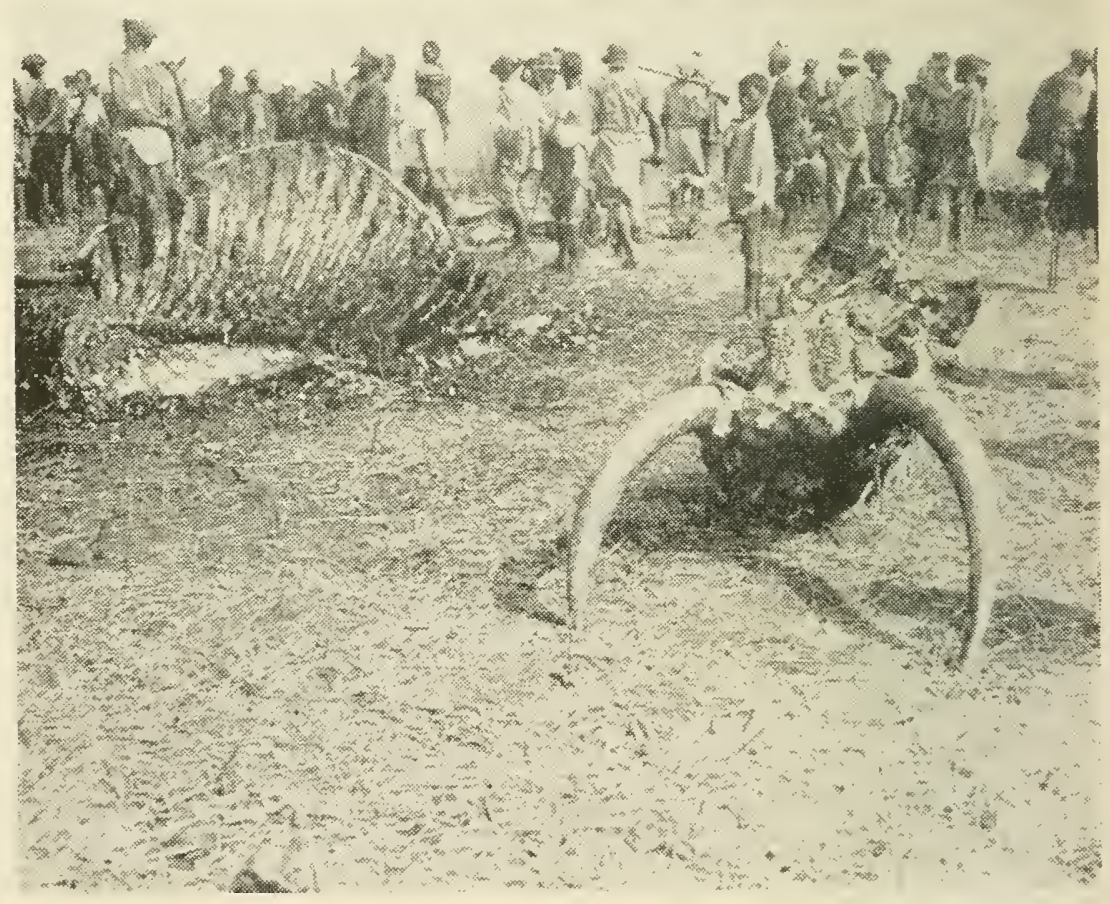

FIG. 37.-Head and skeleton of African Elephant. 
that of the Indian Elephant, which is concave), and the longer legs. General colour dark grey-brown or slatebrown. 'The hairs of the tail are black, thick and wiry, and from these bracelets are made by the natives of Central and East Africa. Height at the shoulder from 9 to 12 feet. Length of tusks from 1 to 7 feet, the

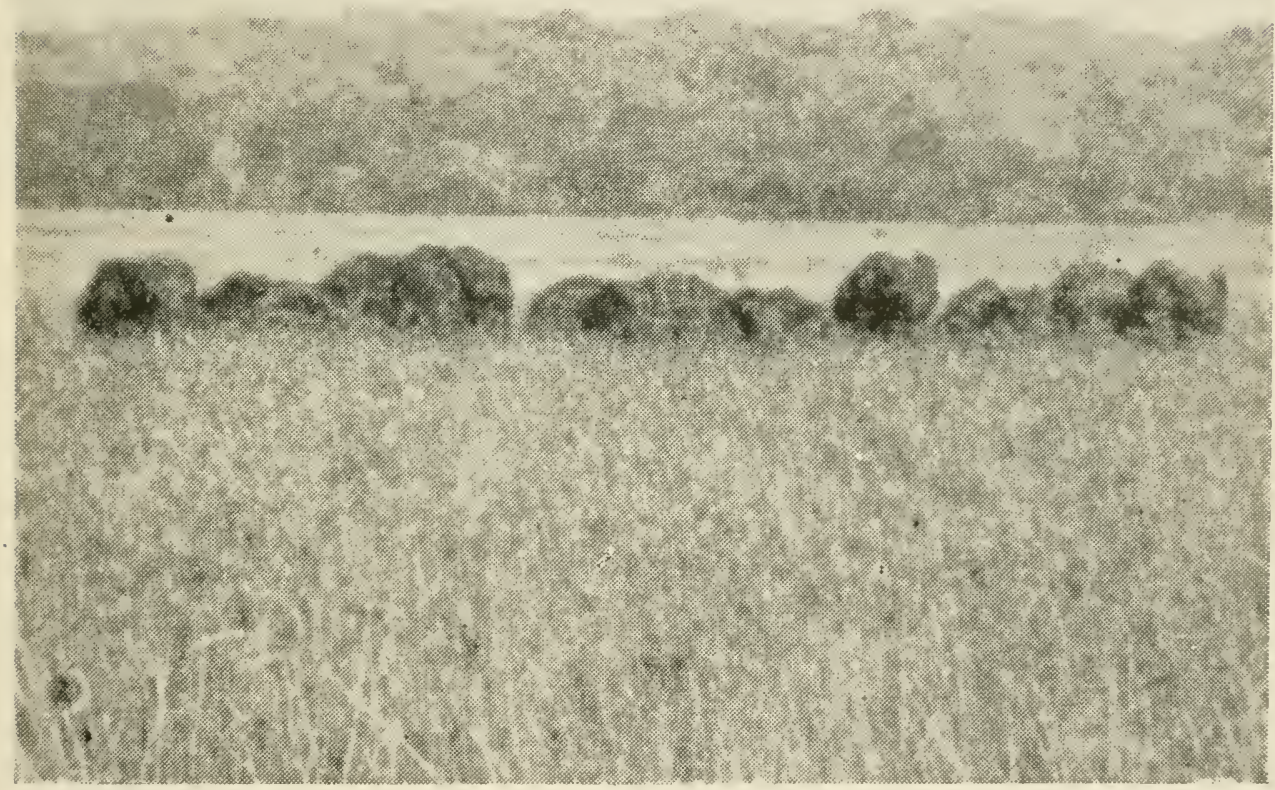

FIG. 33.-Herd of Elephants feeding in the marshes of MIaputoland

males' being usually from 2 to 5 feet, while females' seldom reach a length of more than 3 or 4 feet. Selous gives the average weight of those of South African males at $50 \mathrm{lb}$, and of the females at 10 to $14 \mathrm{lb}$.

The record pair known came from Kilimanjaro and weighed 225 and 235 lbs. respectively, and were 10 feet 4 inches in length. A pair in the Transvaal MIuseum, 


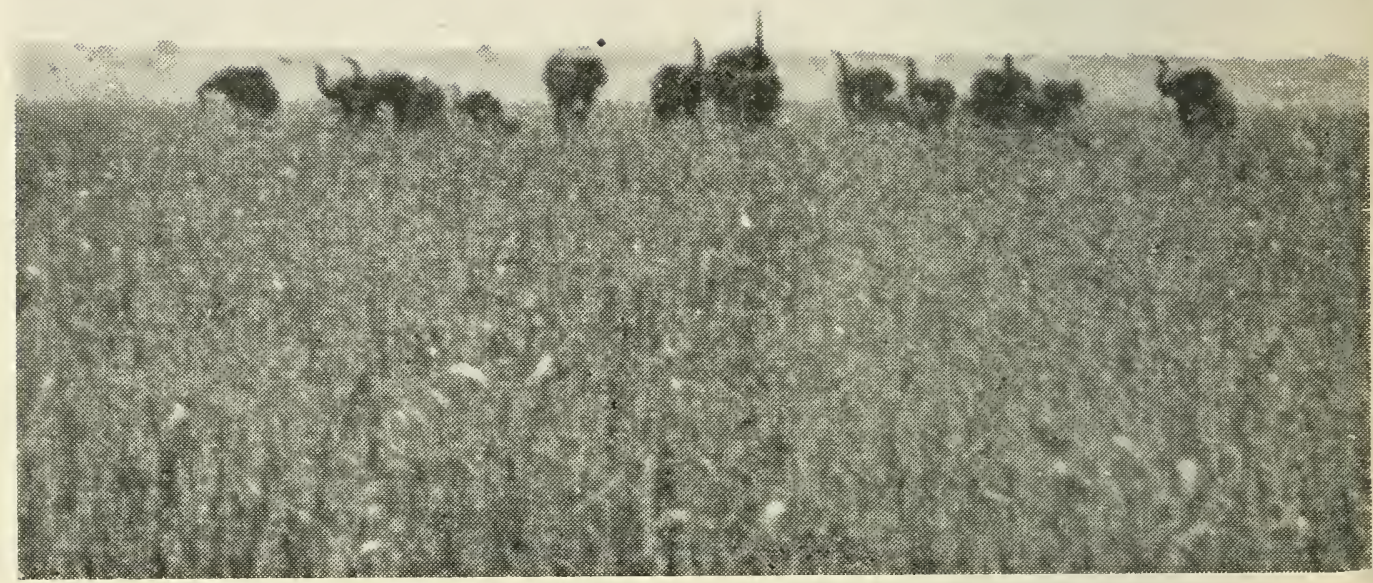

FiG. 39.- IVinding the photographer. (Note all their trunks in the air.)

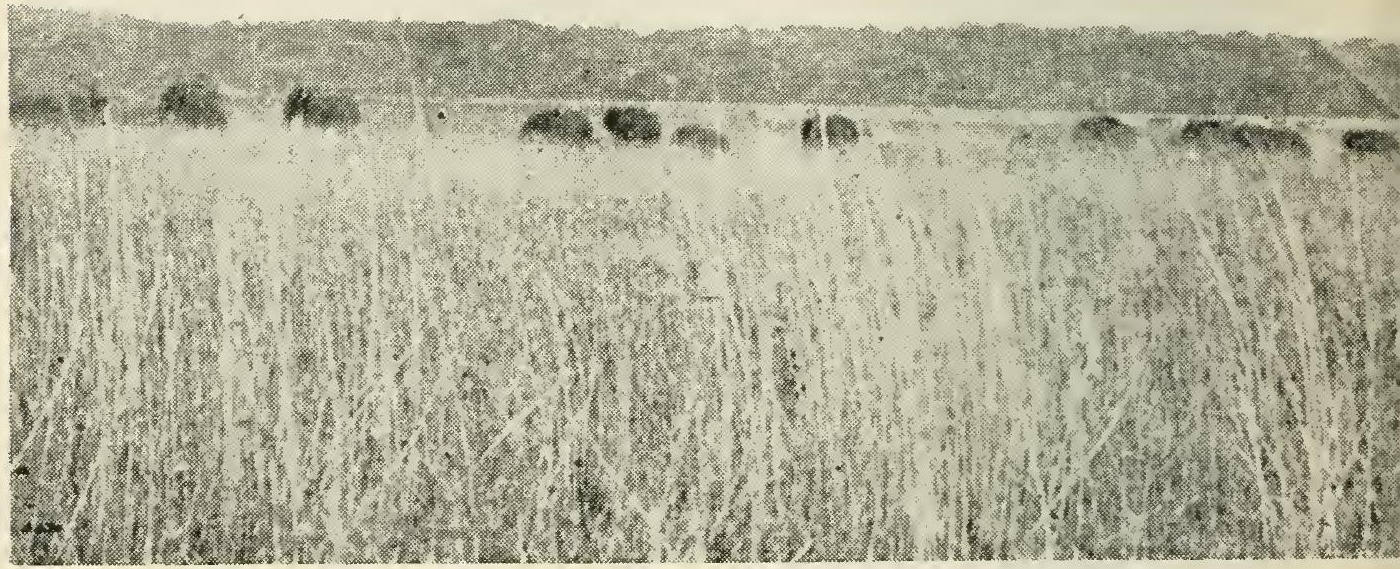

Fig. 40.-The flight back to the shelter of the forest. 
presented by Sir A. Bailey, measures 7 feet 9 inches on the outer curve. Two pairs in the South African Museum measure 7 feet 3 inches and 7 feet 1 inch respectively.

Habits.-Elephants are fond of dark and thick forests or open scattered bush in the neighbourhood of streams. The males go about singly or in small herds during the dry season. They travel preferably by night and stand sleeping under a tree during the daytime. They drink

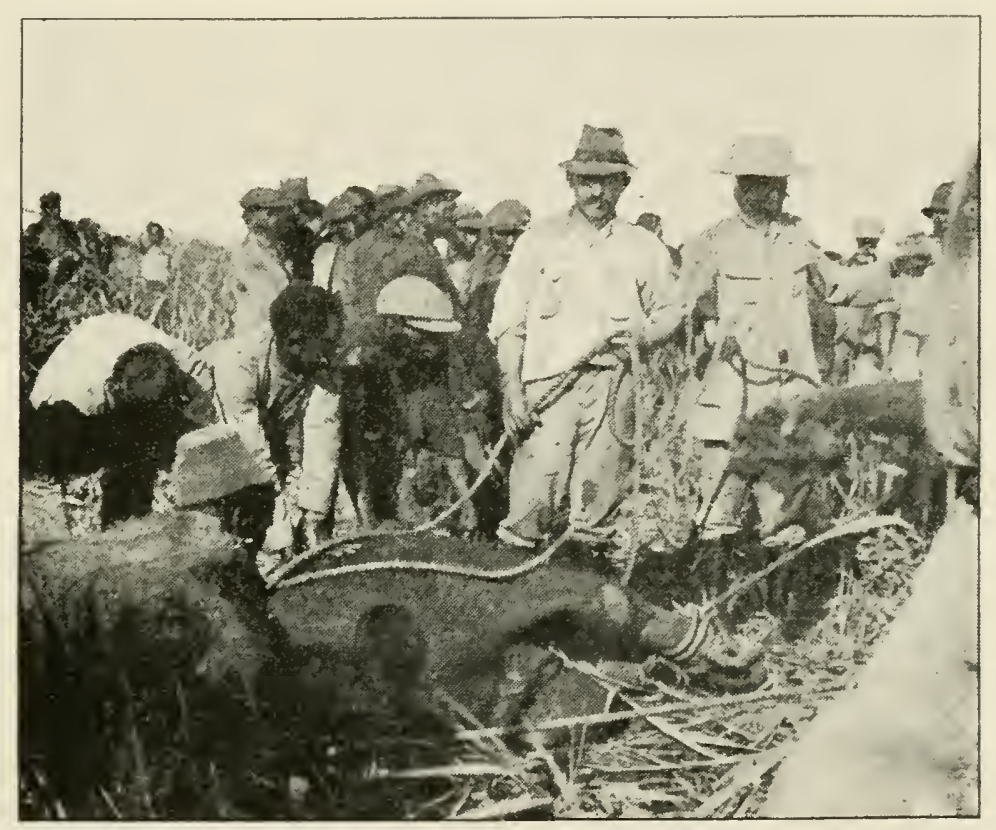

Fig. 41.-Roped up !

and bathe at sundown and feed during the night or in the early morning.

They are herbivorous animals and by reason of their enormous strength can in a single night do a large amount of damage to fences and crops, although their usual food consists of leaves, bark, roots, twigs, fruit and grass.

In South Africa Elephants are to-day only found in the Knysna Forest and the Addo Bush of Cape Colony: 
the Sabie Game Reserves in the Transvaal, and portions of Portuguese South-East Africa, especially Gazaland and Maputoland, where herds of varying size still exist, but which the farmers in the neighbourhood seem determined to exterminate. They were fairly common in parts of Rhodesia, such as Gatooma and Gwaai, \&c., until 1915, when they were considerably shot out. The

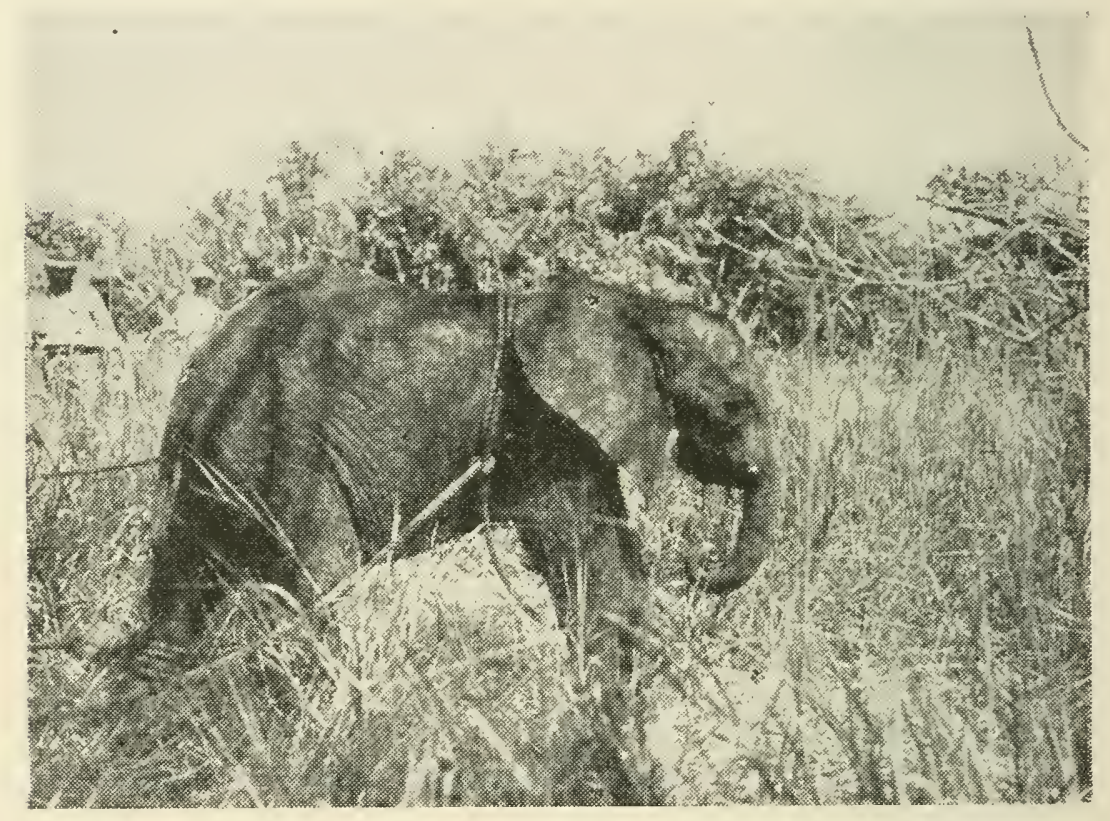

F1G. 42.-Ready for his New Home.

farmers of the Addo area are now doing their best to obtain the extermination of the Addo herd. I think some plan might be devised whereby such a calamity can be avoided. Surely half a dozen individuals would do no harm and would serve to perpetuate the herd.

It is a mystery to me why the African Elephant has not long ere this been domesticated in this country. It can be tamed, as was proved in the case of the famous "Jumbo" of the London Zoo, and it must have been the African species which was used by the Carthaginians. 
We received a wild-caught half-grown female by purchase, in 1913, from Southern Rhodesia and six months after her arrival she could be ridden anywhere in the grounds. Her intelligence is well developed and her

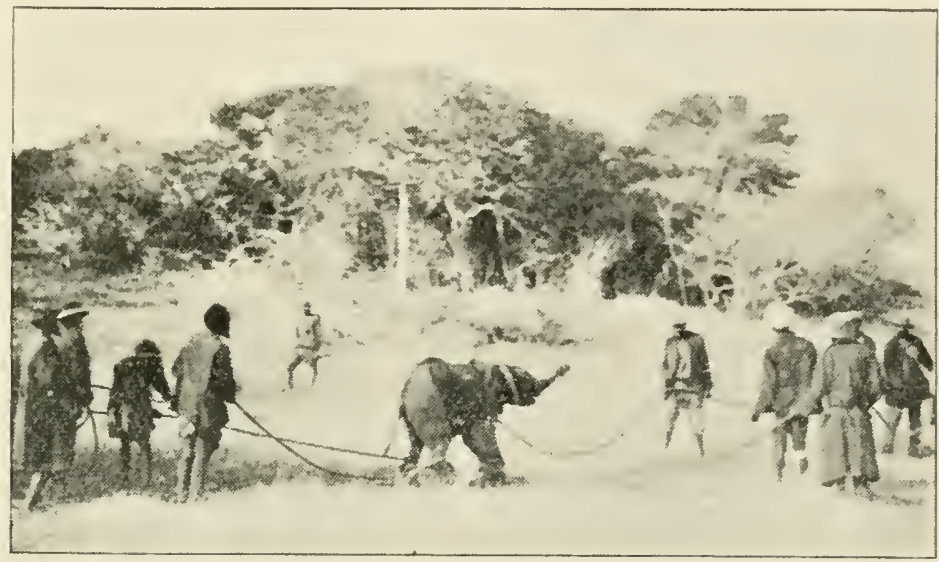

FIG. 43.-Driven to Captivity.

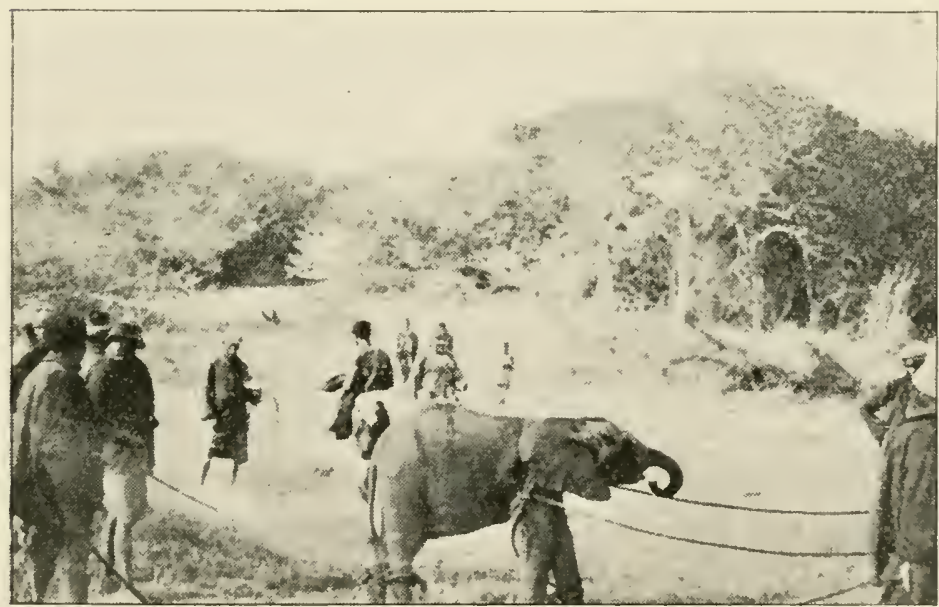

FIG. 44.-Driven to Captivity.

perceptions keen. A couple of months after her arrival she picked up the art of begging from the public and soon became an adept at it, pushing her companiona full-grown Indian Elephant-out of the way in her eagerness and anxiety to appropriate the "tit-bits." 
We taught her to lie down for the saddle to be put on in four lessons, in the first one of which she had to be pulled down by force with her one fore and one hind foot fastened up. She is now ready to do her share of the work.

A young one, caught in Maputoland in 1917, was trained to harness and works daily drawing a plough. Her photogiaph is appended. This is an experiment

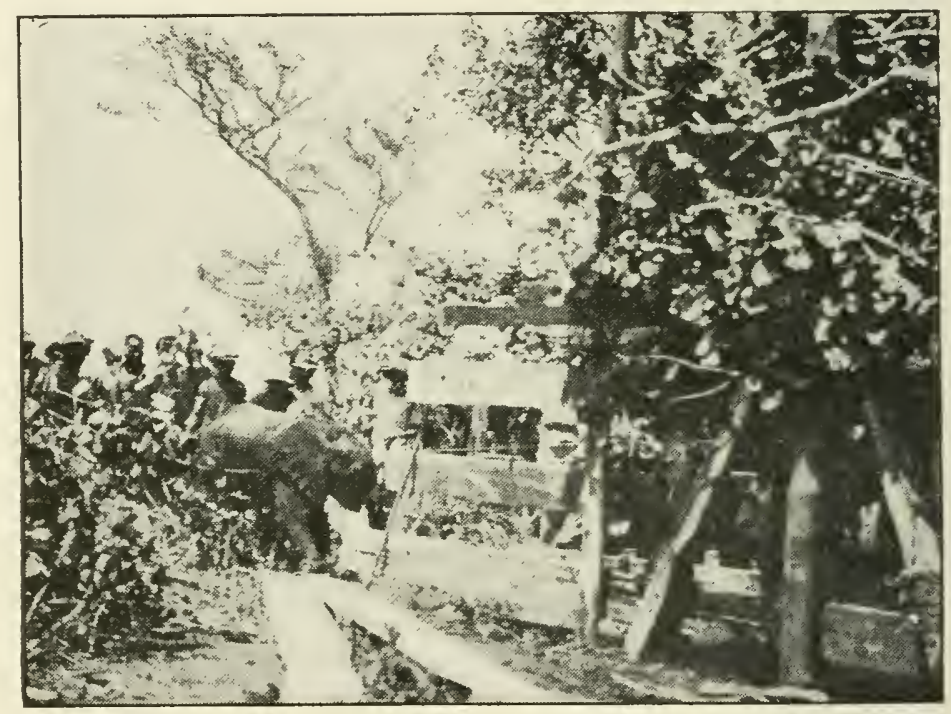

FIg. 45.-The Tast Lap : in to the Box.

conducted by the Portuguese Government at the instance of Mr. Viana Rodrigues, Magistrate of Maputoland at Bela Vista, whose praiseworthy efforts are much to be commended. The Belgian Government has established a training station at Api in the Belgian Congo, where I understand a number of Elephants are in training after the Indian plan. Why cannot we follow their example?

Elephants rarely breed in captivity - even the domesticated Indian animals-and in the wild state only one young one is born. The period of gestation is from twenty to twenty-three months. Their sight is not 
good, but their scent excellent. Elephants are hunted solely for the ivory of the tusks, although the meat is much prized by the natives as food. They are not easy to shoot, notwithstanding their large size, as vital shots are not always possible. The late Capt. Selous was a well-known Elephant hunter, and described in his

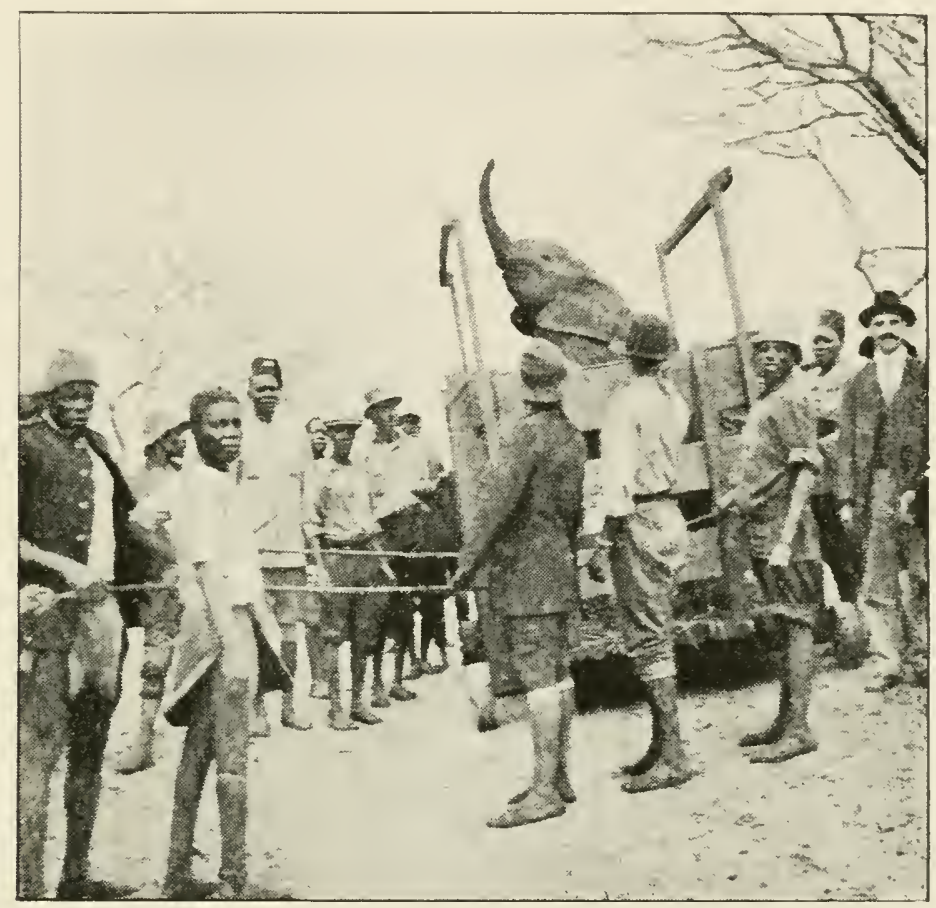

FIG. 46.-The Last Bid for Freedom.

delightful works on big game shooting in South Africa many adventures with these huge pachyderms.

I append a photograph of a medium-sized male shot near Bela Vista, Maputoland, also an enlargement of one of the tiny film-pictures taken in August, 1918, by our party, which had for its main object the filming of wild Flephants in their natural state. This was undertaken by the African Film Productions, Ltd., of Johannesburgwhose guest I was for the trip-and which was, thanks mainly to the Portuguese authorities, an unqualified success. 


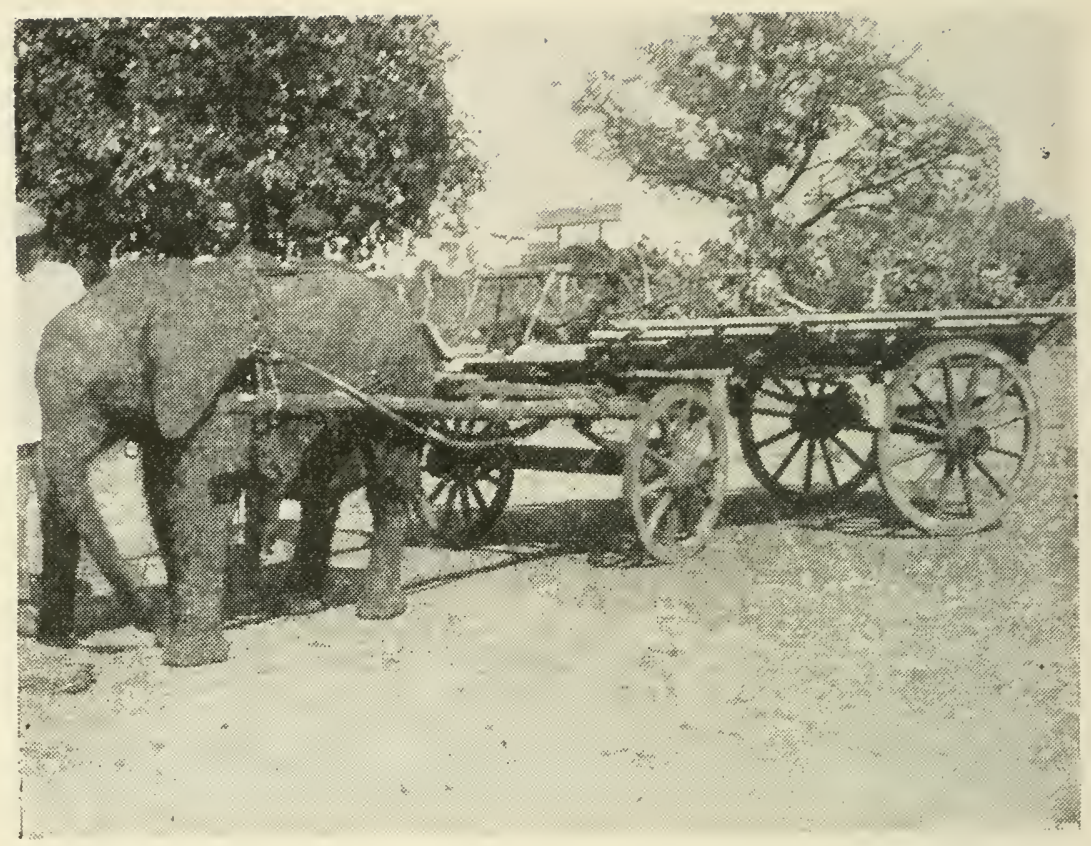

FIG. 47.-The training of a South African Elephant. Pulling a lorrie.

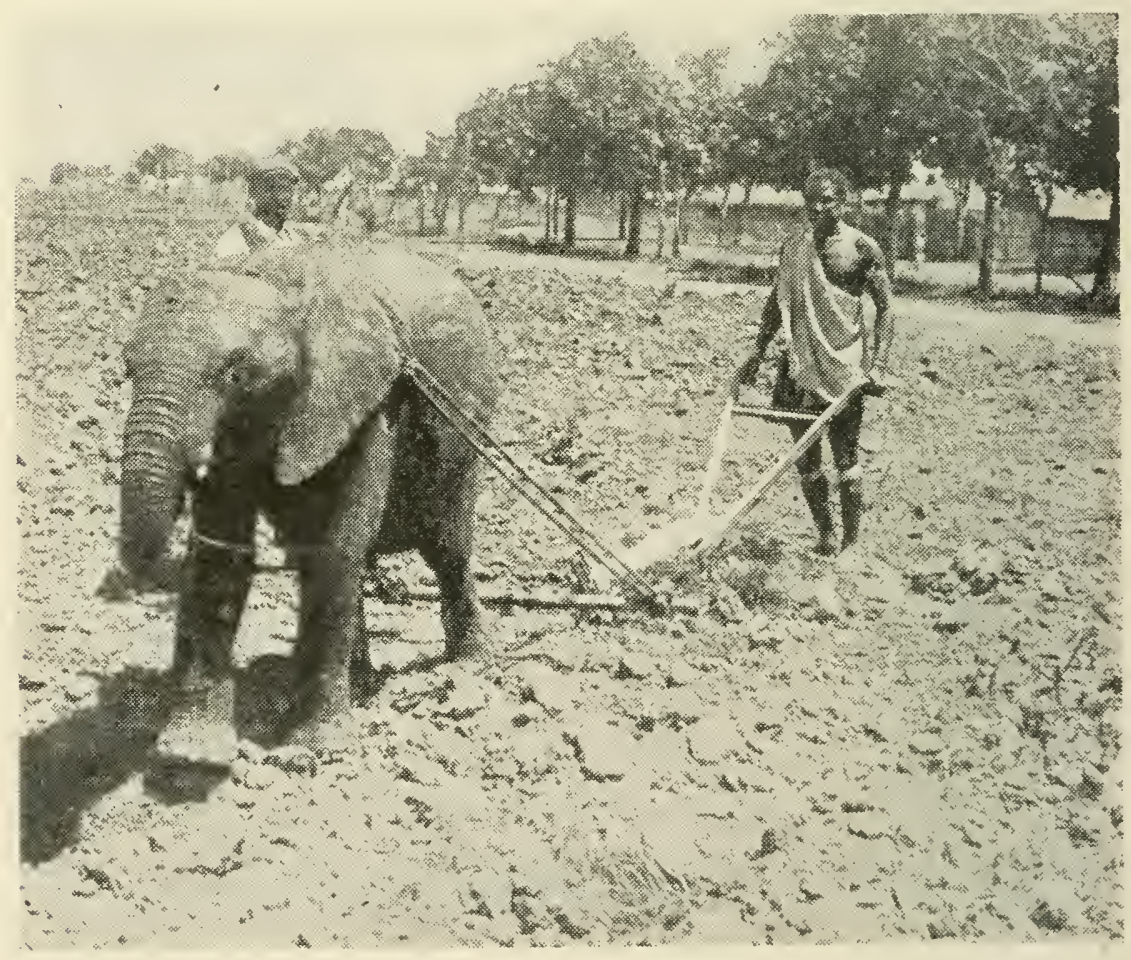

FIg. 48. - The training of a South African Elephant. Ploughing. 


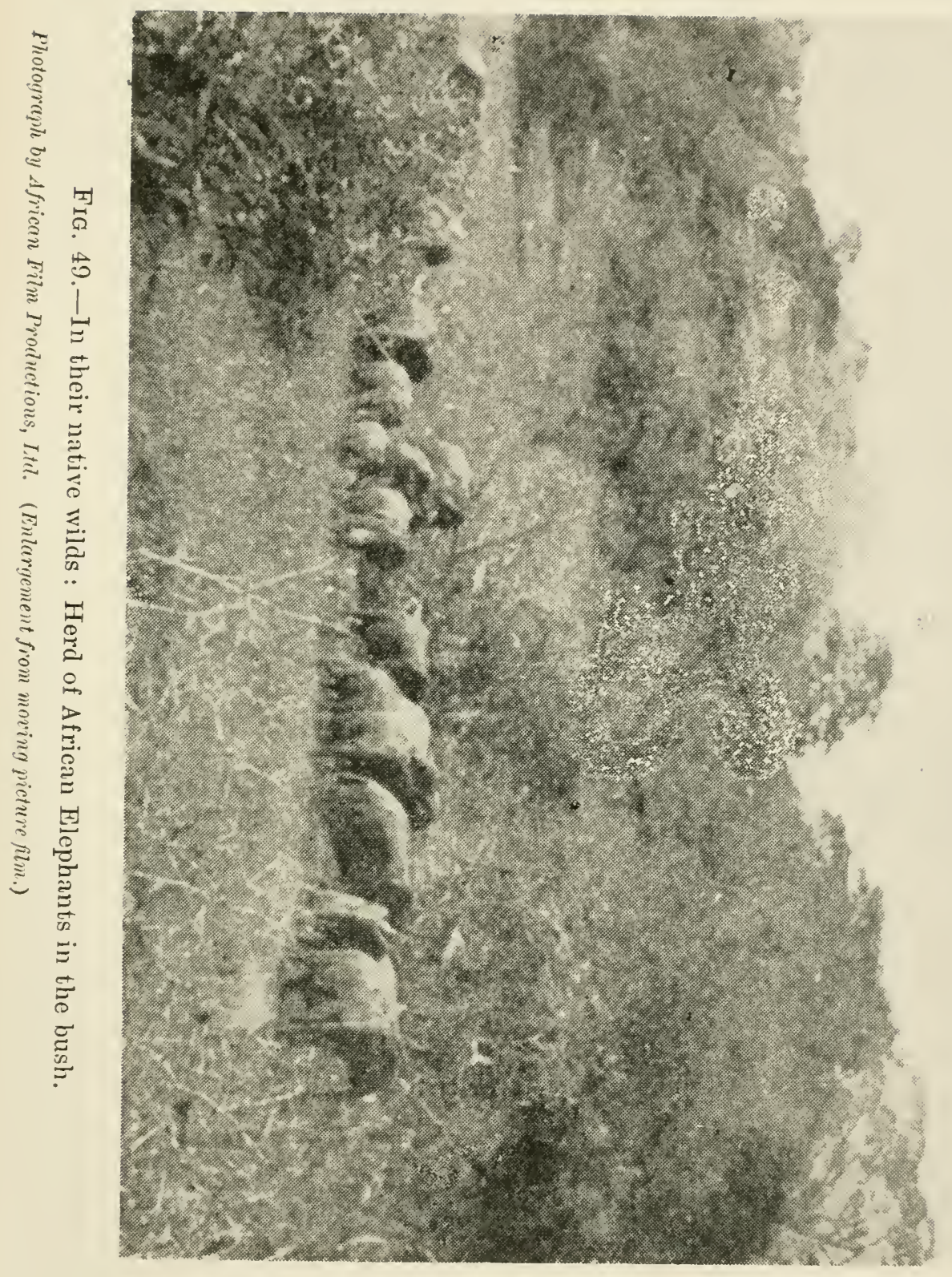




\section{Order UNGULATA.}

This is a large order containing the true "hoofed" animals, and excluding under the more modern and generally accepted classification the Elephants and Rock Rabbits. The digits of the forefeet never exceed four in number, and the carpal and tarsal bones interlock. There are no clavicles.

There are three sub-orders, the Perissodactyla, containing the Tapirs, equine animals and Rhinoceri; the Artiodactyla, containing the Pigs, Hippopotamidæ, ruminant animals; and the Lipoterna, embracing certain extinct forms which need not concern us further.

\section{Sub-Order PERISSODACTYLA.}

This group contains the Rhinoceri, equine animals and Tapirs (which last are not found in Africa). Middle toe larger than the others; this may be the only functional digit, as in the case of the equines. Toes of the hind foot never more than three in number. Dorso-lumbar vertebre 23 or more in the living forms. Premolar and molar teeth in a continuous series with massive crowns. Dentition frequently complete, viz., incisors 3-3, canines 1-1, premolars 4-4, molars 3-3 $=44$.

Stomach simple; gall-bladder not present.

\section{Family RHINOCEROTIDÆ. Genus DICEROS.}

Large aud clumsy animals with thick skins almost devoid of hairs, these being found only on the tail and ears. Eyes extremely small for the size of the animal. 
There are two horms growing from the upper surface of the face; these horns are not attached to the skull, nor are they of bony growth.

'The feet have three toes, each provided with a broad hoof. 'I'he number of teeth varies considerably, ranging from 28 to 38 . Trouessart separates the two African species into a genus of their own, Diceros, retaining Rhinoceros for the Asiatic animals.

Diceros simus. Siqure-mouthed Rhinoceros. Witte lihenoster.

This animal-commonly known as the White Rhinois now very scarce, being at present only found in Zululand (where it is even uncommon and where a special reserve exists for its preservation), parts of Rhodesia and Centrai Africa. Formerly it was common in Bechuanaland and Mashonaland. This is by far the largest of the tro Rhinos found in South Africa, and is indeed the second largest terrestrial mammal alive to-day; it is further distinguished by its slightly paler (slaty) coloration and square upper lip. The tail is provided with a tuft of stiff bristly hair. There are two horns on the face which vary much in size and shape. The total length of the head and body is about 13 feet; tail 2 feet. Height at shoulder 5 feet 6 inches to 6 feet 6 inches. Length of front horn 35 to 50 inches. Record 62! inches; rear horn 17.8 inches.

The White Rhino is found in open grass veld and is of somewhat solitary habit. It feeds at night or during the early mornings, and evenings after sunset, and sleeps during the hot part of the day. Its pace is fair for the bulk of the animal, but no match for a horse. The food of this species consists entirely of grass. Its sight is bad but its hearing and scent are correspondingly good. Only one young one is born at a time. 
Diceros bicornis. Black or Prehensile-lipped Rhinoceros Zwarte Rhenoster.

The common Rhinoceros at one time roamed the country from Cape Jown to the Zambesi. At present it is not found south of the Zambesi except for a few in the Eastern Transvaal, Zululand and the Portuguese territory. Northwards it extends to Somaliland, being still common in East Africa.

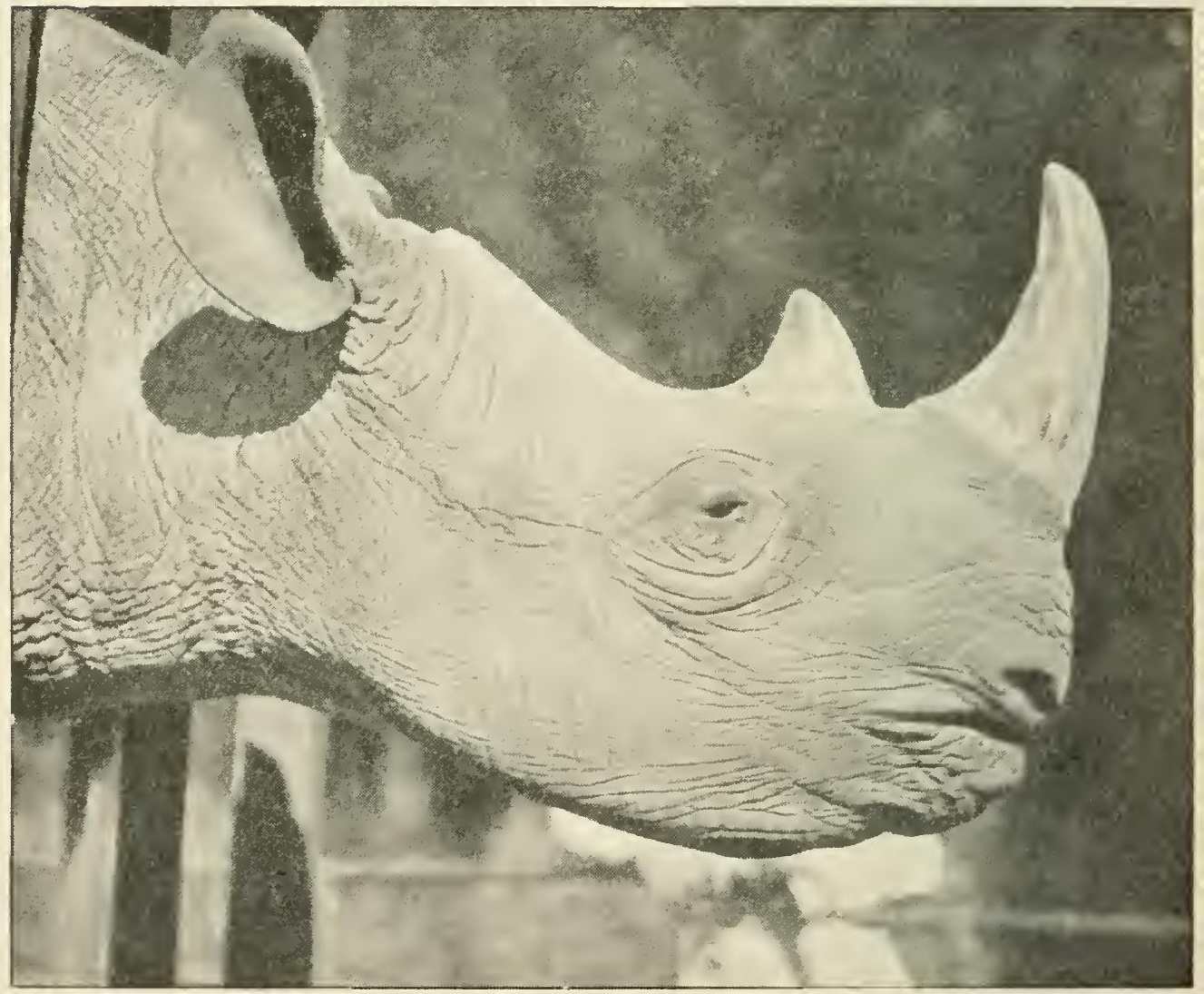

FIG. 50.-Head of Black Rhino.

It is smaller than the White Rhino and has the upper lip attenuated in the middle, forming a flexible or prebensile organ, wherewith to facilitate the grasping of the reeds, leaves, plants, dc., which form its food. 'The 
terminal two-thirds of the tail is provided with bristles. It also has two horns, which are variable in length and shape, but never apparently attaining anything like the length of those of a White Rhino.

Length 10 feet. Height at shoulder about 5 feet. Length of fore horn 18 to 20 inches on the average, the record being $41 \stackrel{1}{2}$ inches; rear horn 7 to 8 inches, record 19 inches.

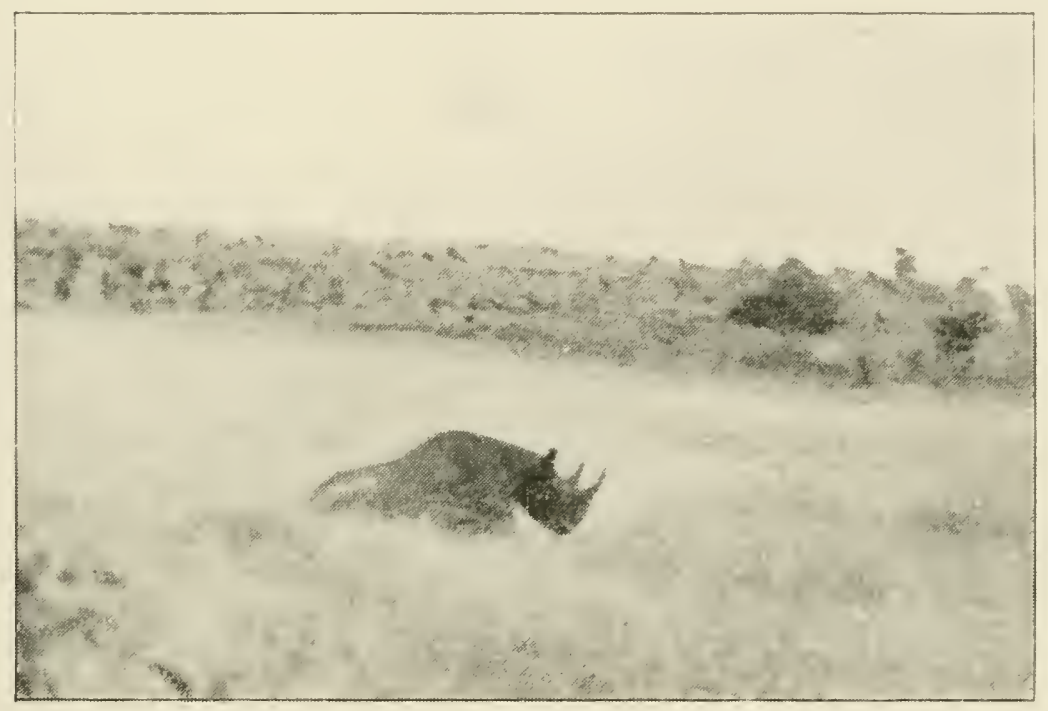

FIG. 51.-Wounded Rhino-"German" East Africa.

Unlike the White Rhino, the Black Rhino is usually found in bushy country, and is also of a solitary disposition. In habits it resembles the former, excepting: in its diet, which consists almost exclusively of leaves, twigs, roots, Sc., but seldom of grass. A great deal has been written on the pugnacious nature of the Black Rhino, most hunters saying it will charge without provocation. Its small eyes are bound to give the creature bad eyesight, but its hearing is well developed, and I expect they vary individually as much as any other animal. Mr. Dugmore, in his beautiful book on "Camera 


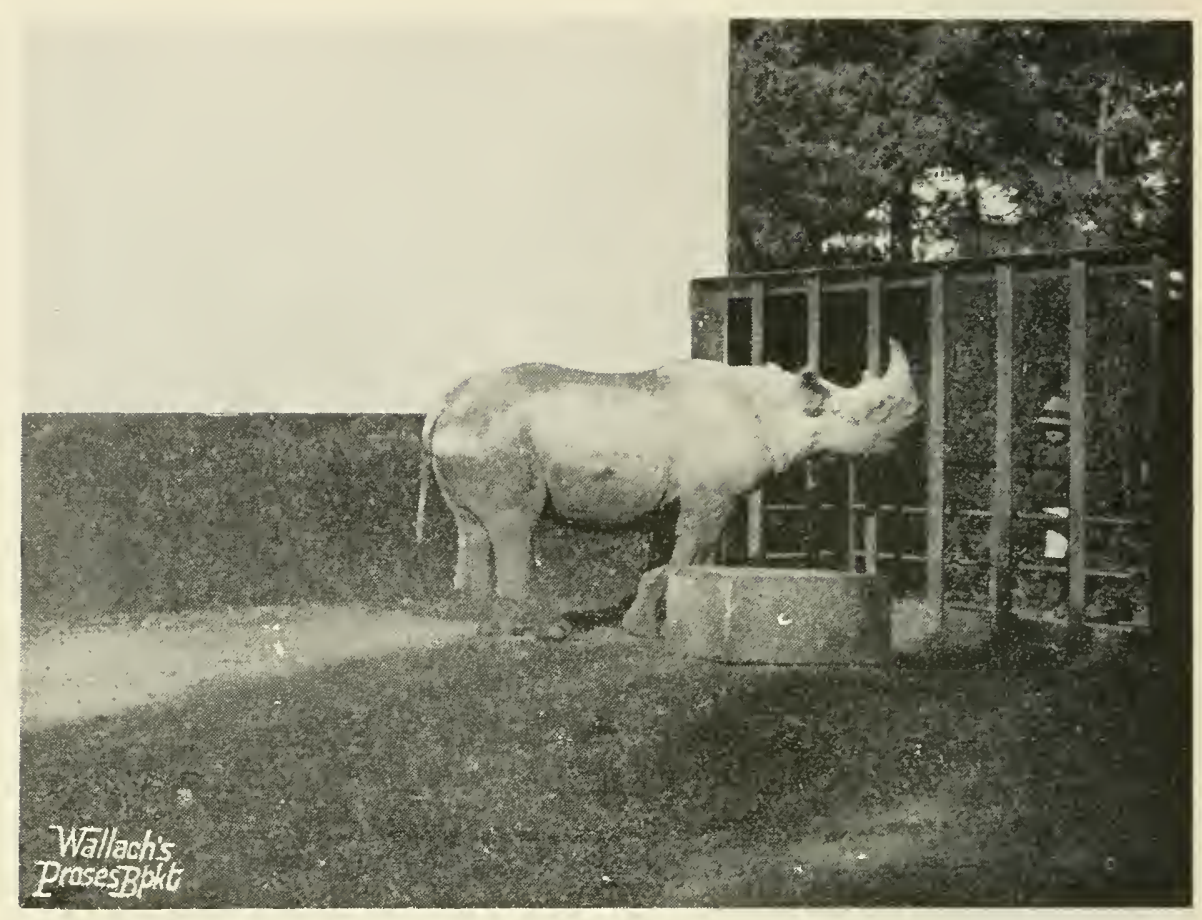

Frg. 52.-Young Black Rhino, six years old (male). (Note the prehensile lip.)

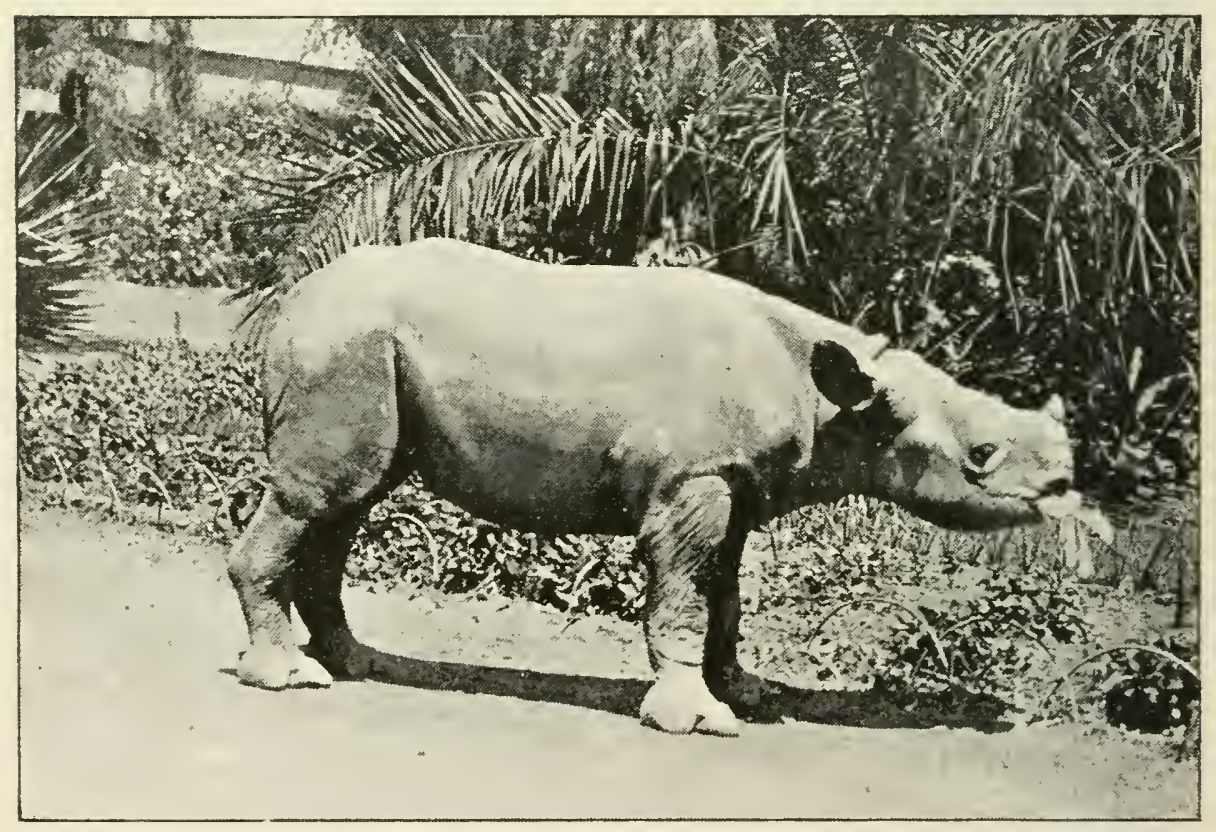

FIG. 53.-Baby Rhinoceros from N. Rhodesia. 
Adventures in East Africa," states that in one district of East Africa the Rhinos were quiet and docile or timid animals, in another quite the reverse, charging for no apparent reason. The National Collection possesses two of these animals, a bull from German East Africa and a cow from South Central Rhodesia. The former is becoming very troublesome now, although quiet enough for the first eight years of his life in captivity; the latter is quiet and tractable, and will follow one about like a dog.

Family EQUID Æ.

Head lengthened, neck adorned with a mane; tail with long hairs; naked patches (chestnuts) on the insides of the forelegs; mammæ two in number. Feet encased in a horny box or hoof. Dentition: Incisors 3-3, canines $1-1$, premolars $4-4$, molars $3-3=44$. The first premolar is small and drops out early in life, not being replaced, so that the mature dentition totals 40 .

The true Quagga was striped as far as the shoulders only and has long been totally extinct.

\section{Hippotigris burchelli, Gray. Burchell's Zebra. Bonte Quagga.}

The main characteristics of the Burchell's Zebra (which has been split up into a number of varieties, species or geographical races-call them what you will) are :-

(1) A more equine appearance than that of the Cape Mountain Zebra; shorter ears, and no dewlap.

(2) The presence of the so-called shadow stripes-a paler stripe in the white field dividing the black stripes.

(3) No gridiron pattern on the back, and the hair on 


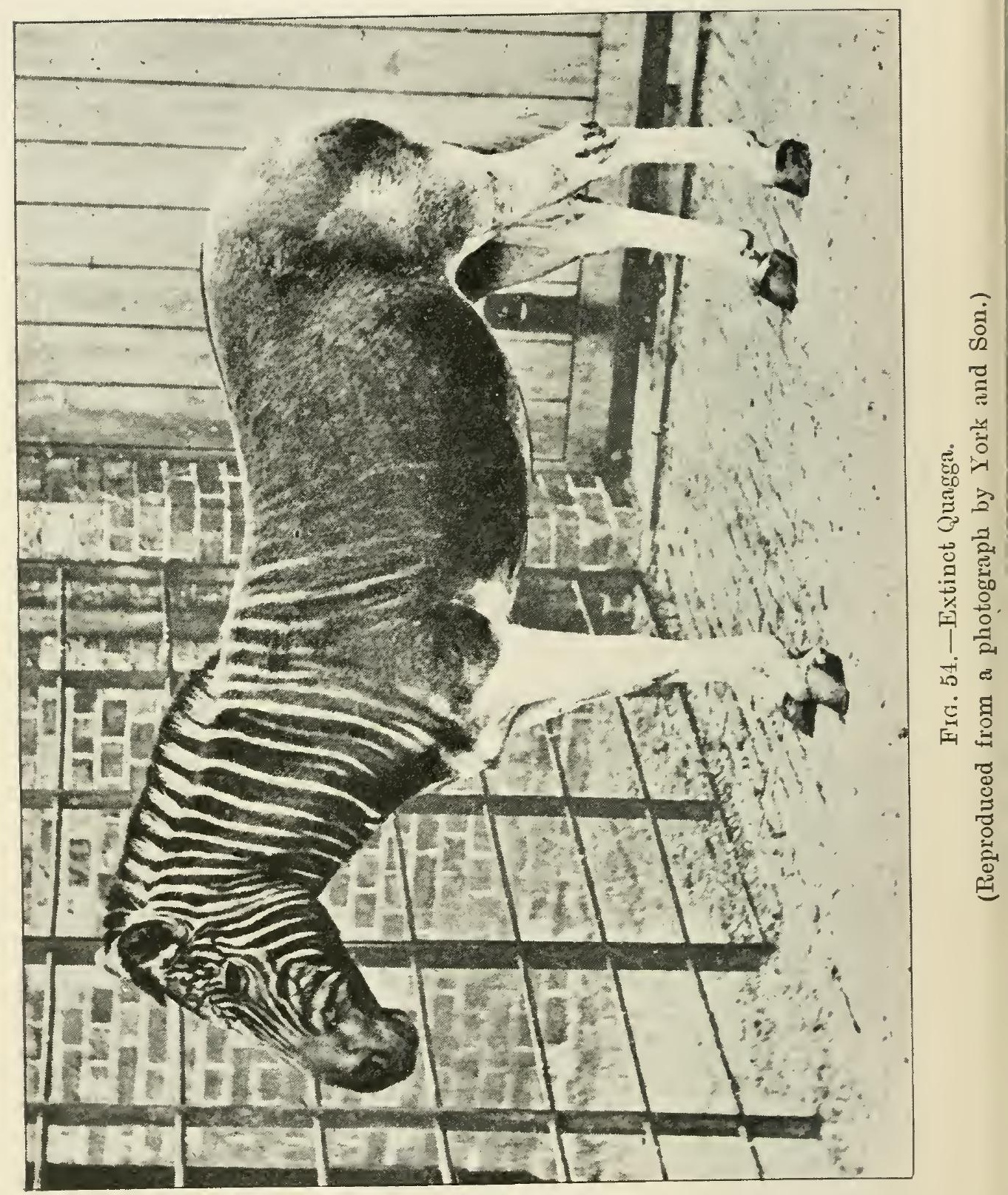


the haunches and withers not reversed as in the Mountain Zebra.

The sub-species mentioned in Sclater's "Mammals of South Africa," are :-

Hippotigris burchelli typicus: Barrel stripes not meeting the ventral line under the belly; legs unstriped.

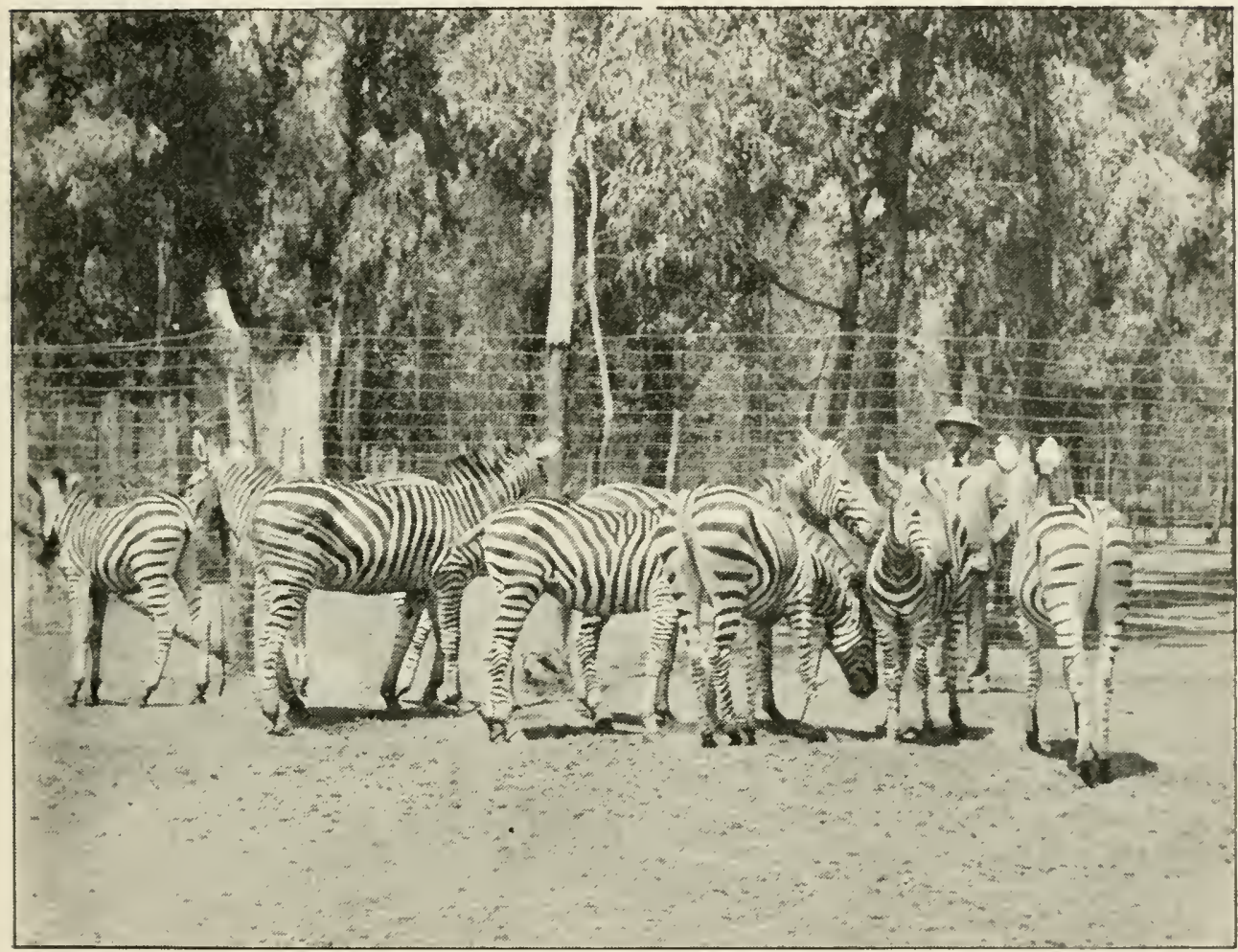

Frg. 55.-Burchell's Zebras: Chapman's and Transvaal varieties and one Crawshay's Zebra.

Hippotigris burchelli antiquorum: Same as above, but legs lightly striped to hocks and linees.

Hippotigris burchelli transvaalensis: Barrel stripes meeting the ventral (belly) stripe; shadow stripes extending to neck; lower portion of legs only slightly marked.

Hippotigris burchelli wahlbergi: Barrel stripes as 


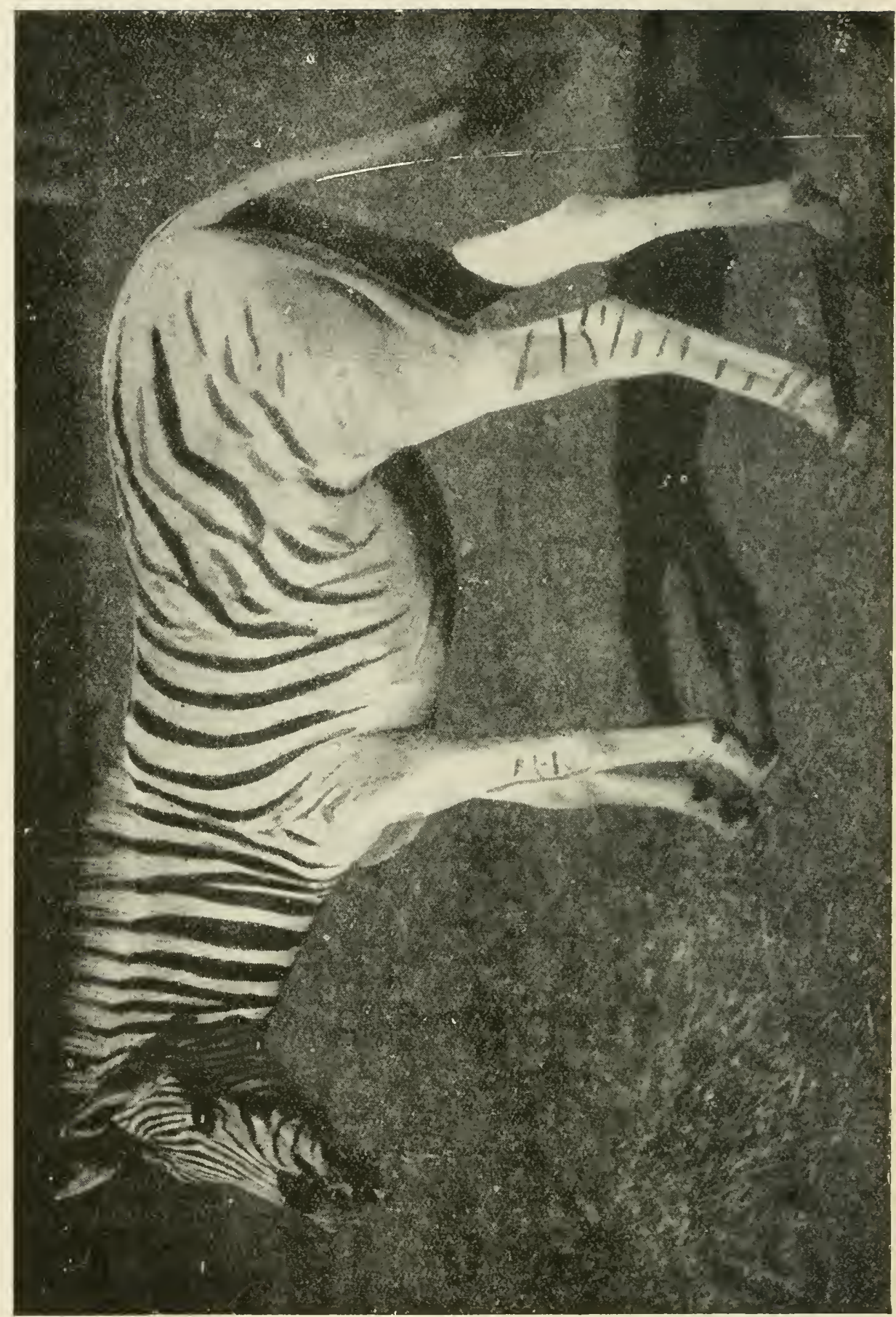

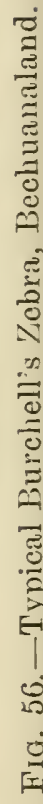


above; shadow stripes distinct only on the quarters; fetlocks and pasterns plain.

Hippotigris burchelli chapmanni: Barrel stripes as above; shadow stripes on quarters faint and narrow; stripes on lower part of legs indistinct; pastern not altogether black.

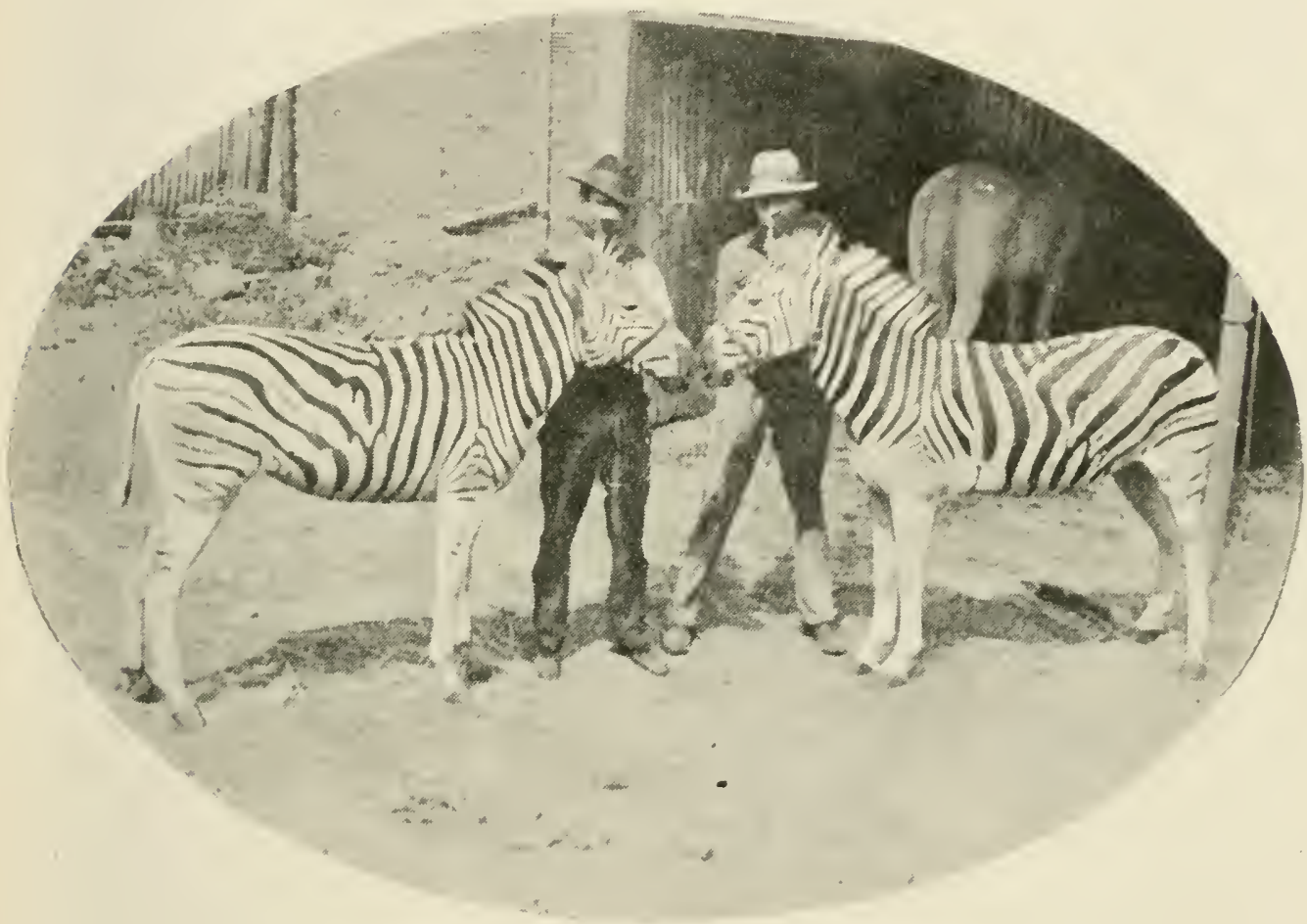

Fig. 57.-Burchell's Zebras from Zululand.

Hippotigris burchelli selousi: Barrel stripes as above; shadow stripes as in chapmanni; legs strongly striped to the hoofs; fetlocks and pasterns quite black.

The writer has had the opportunity of studying some hundreds of Zebras during the ten years he has been connected with the Pretoria Zoological Gardens, and can safely say that in his opinion the above series of subspecies is quite wrong. We have, for instance, at present in the collection two Zebras from Bechuanaland (Lake 
Ngami area), one of which, the stallion, is antiquorum in all its details, while the mare is almost a typical burchelli; she is intermediate between burchelli and antiquorum, inasmuch that the hocks, kuees and fetlocks are slightly striped, but the lower half of the hips, the lower belly and

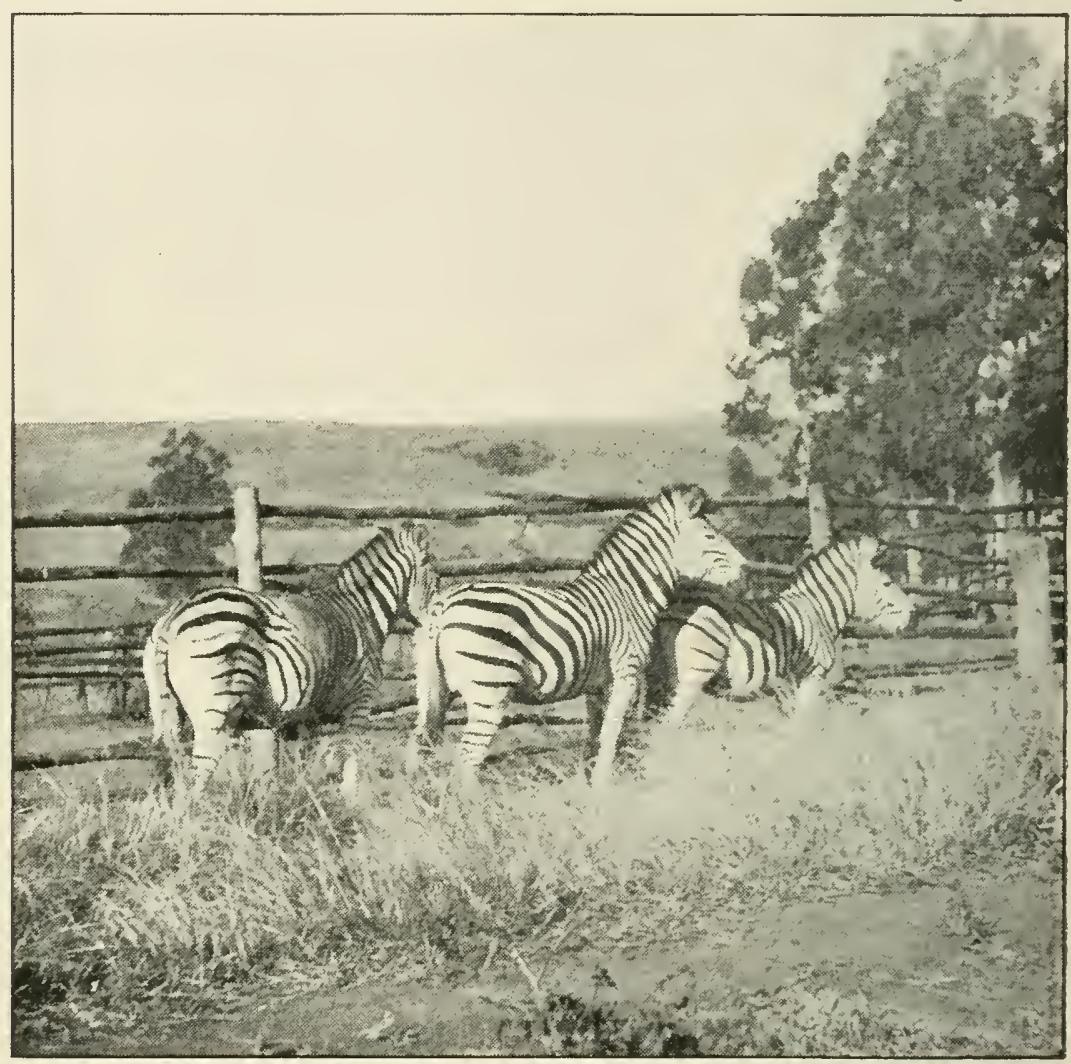

Fig. 58.-Burchell's Zebras from Zululand.

most of the legs are unstriped. (See photo: this has, however, been unfortunately retouched by the block makers, and a number of stripes put in which do not exist on the living animal.)

Two examples from Zululand are neither wahlbergi nor chapmanni, partaking of the characters of both, and in these only the first two barrel stripes join the median 
longitudinal line of the belly. We had lots of six, eight and ten individuals, caught out of the same herd in the Northern Transvaal, which contained typical selousi (see

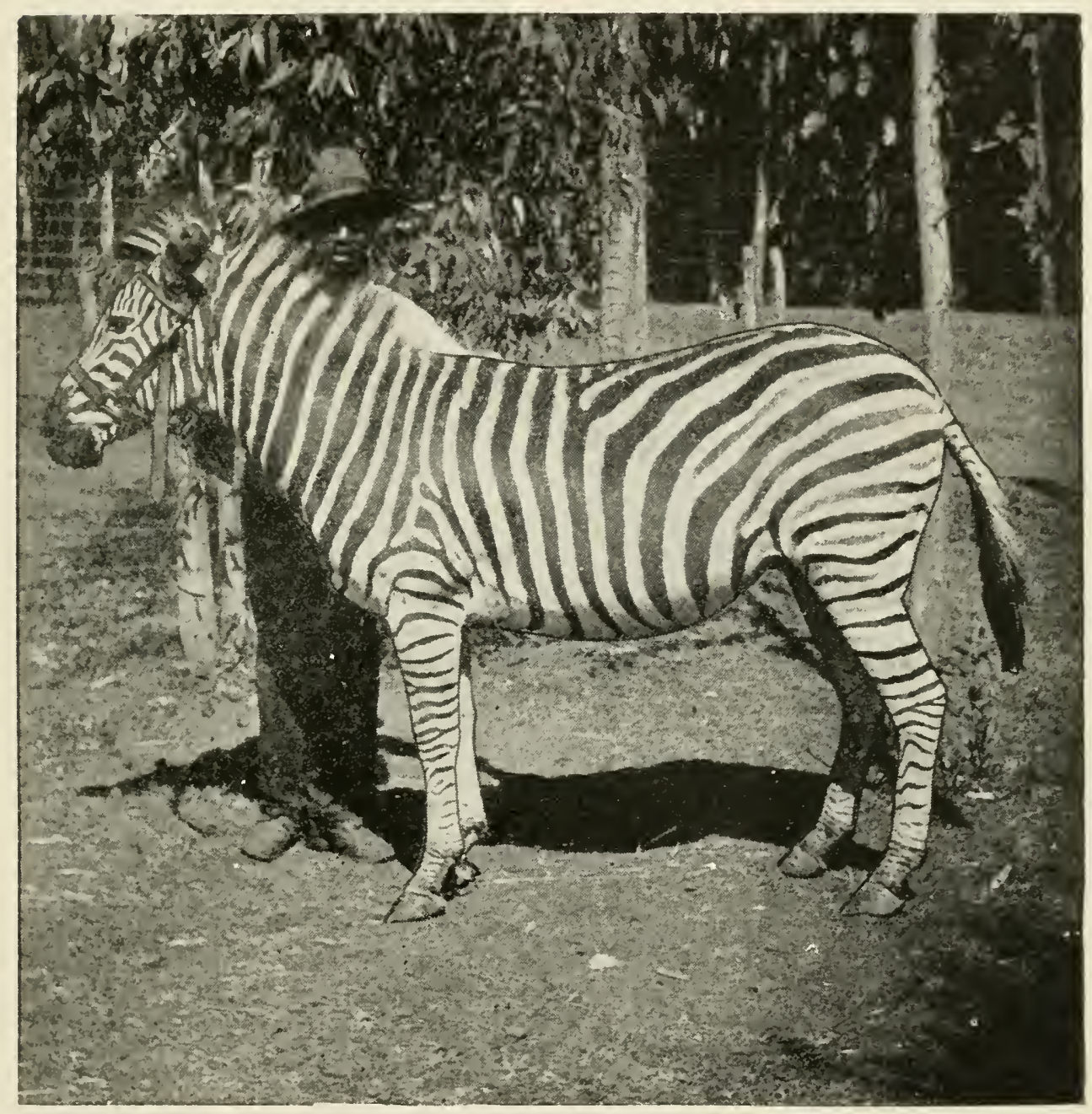

FIG. 59.-Heavily-marked Chapman's Zebra (Northern Transvaal).

illustration), chapmanni and all the intermediate stages between the two extremes. What then is the sense or use of employing these sub-specific names as geographical races when they do not exist as such, and when examples 
of almost every so-called race can be picked out of one herd in the Northern Transvaal? So far as I can see from our records, the heavily marked form (selousi) is never found in Bechuanaland on the one side nor Zululand on the other; and, if it could be proved that the joining of the barrel stripe with the median belly line was constant in both the dark and light forms (i.e., lightly and heavily marked), as seems to be the case, then this might

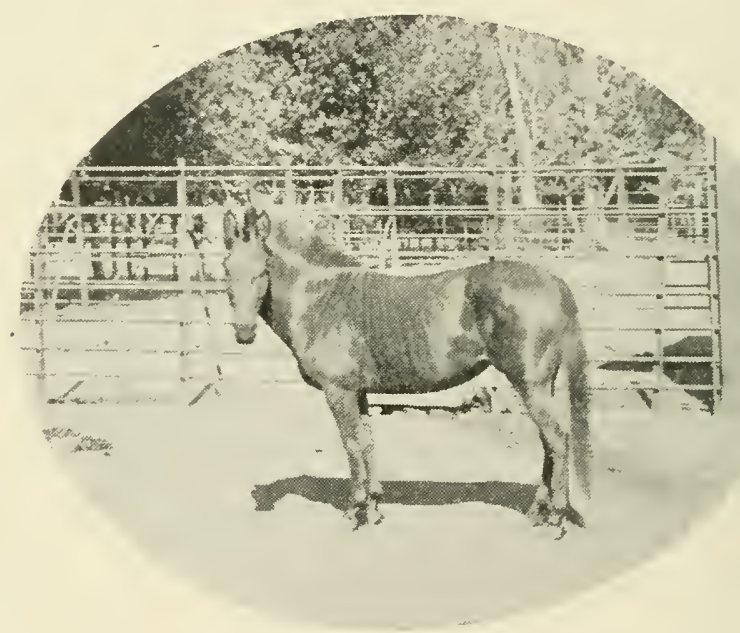

FIG. 60.-Zebroid.

be used as the determining factor, and two species, or sub-species, recognized, named burchelli and chapmanni. The Zebras from the Rustenburg district of the Transvaal are of the lightly-marlied variety, so far as our records go, and are therefore in this particular nearer the Bechuanaland form. Only large series from the various localities can settle this question definitely, but for me there is only one, or at most two, varieties of Burchell's Zebra.

'The height of Burchell's Zebra at the shoulder is 4 feet, and the total length of the head and body 8 feet 
(head and neck stretched out, and measured from the tip of the nose to the root of the tail); tail, 2 feet 6 inches.

Hippotigris crawshayi. Northem MIountain Zebra.

Noordelike Berg Zebra. Kleine Wilde Paard.

Similar in build, size, \&c., to the Burchell's Zebra, to which it is linked by some zoologists and treated as a sub-species. As the animal is totally devoid of shadow

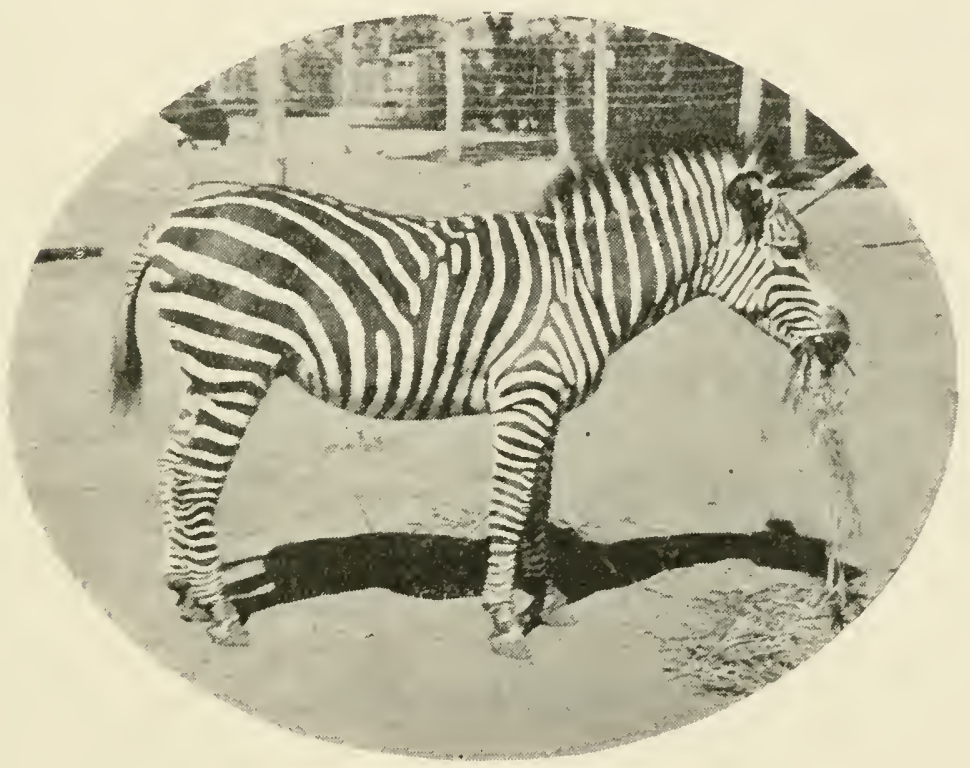

FIG. 61.-Crawshay's Zebra.

stripes, I think it should be treated as a separate species, along with Grant's Zebra of East Africa.

This animal is striped all over with solid black and white markings, the barrel stripes meeting the median longitudinal belly line, and not as is the case with the Cape Mountain Zebra, where the barrel stripes stop on the sides of the body, leaving a pure white belly. It also has no dewlap, and is, like the Burchell's Zebras, of equine build. The legs are striped to the hoofs, the 
pasterns being black. Muzzle, dark russet or tan colour. Originally described as from the high country west of Lake Nyassa, Mr. W. L. Sclater records this animal from Beira in Portuguese East Africa. The Zoo obtained a stallion from the north of Northern Rhodesia, which was said to. have been captured between Lalies Mweru and Bangweolo, and which seems referable to Rothschild's annectens, but.

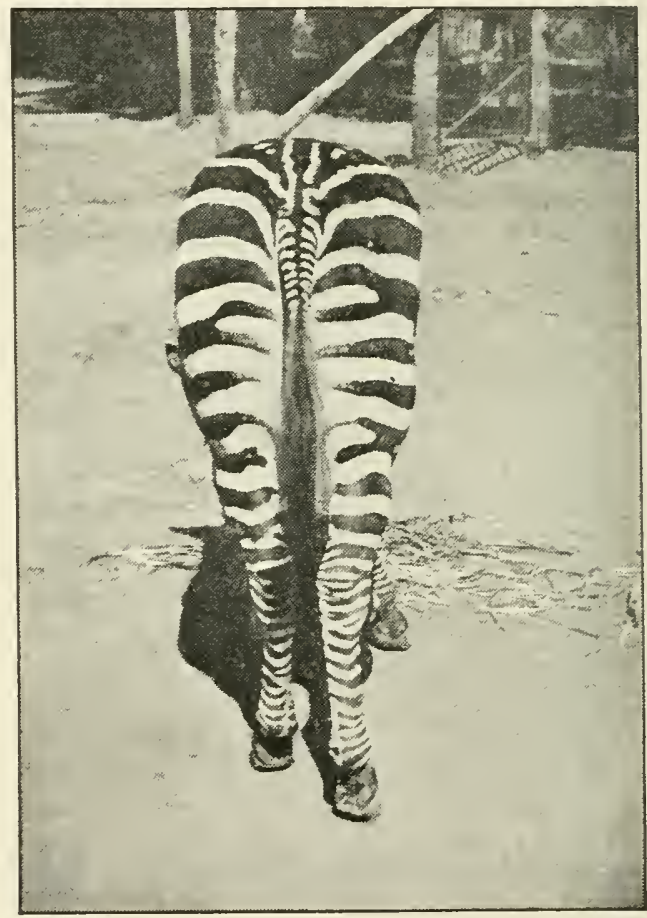

Fig. 62.-Crawshay's Zebra.

the muzzle is tan-coloured. A mare received from the southern portion of Northern Rhodesia, near the Kafue River, resembles the stallion to a marked degree. The Walker Brothers, of Choma, inform me that this animal is common in this region, and inhabits the hilly country, whereas the Burchell's Zebra is found on the plains. Photographs of the stallion are appended. 
Hippotigris zebra. Mountain Zebra.

Berg Zebra. Wilde Paard.

Striped black and white, the black stripes being broader than the white; tips of the ears white; the markings on the back are arranged in a sort of gridiron pattern; legs

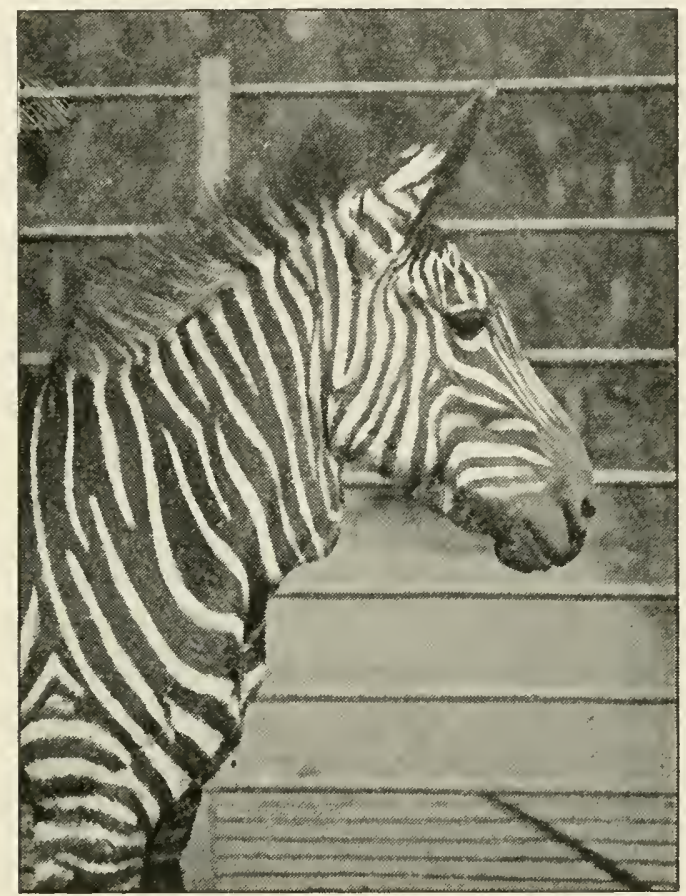

FIG. 63.- Head of Cape Mountain Zebra. (Nare, showing dewlap.)

ringed black and white, the lower portion, the pastern, entirely black; the stripes on the hips very broad, much broader than those of the previous species. The main difference between this animal and the Burchell's Zebra is the solid black stripes alternating with the white; the latter animal has what is known as shadow stripes in between. The long ass-like ears and the peculiar dewlap-like flap of skin under the throat, easily distin- 
guishes this animal from any other species of Zebra Length, about $8_{4}^{1}$ feet; height, 4 to $4 \frac{1}{2}$ feet, stallions (the mares are smaller). The range of the Mountain Zebra is restricted to a few mountainous districts of the Cape Colony: Graaf Reinet, Oudtshoorn, Uitenhage,

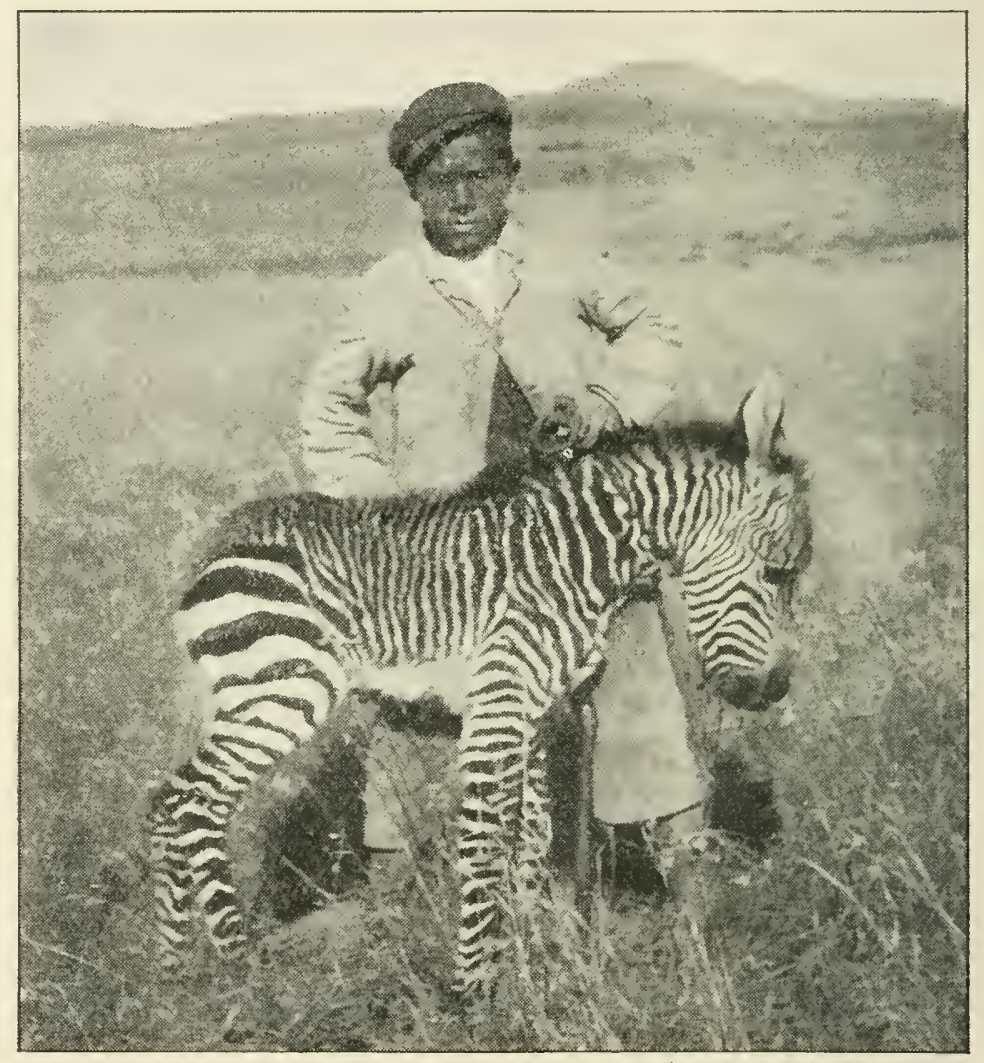

FIG. 64.-Baby Cape Mountain Zebra.

Cradock and one or two more. It also occurs in SouthWest Africa, which form has been separated under another name, hartmanne. This sub-species is also illustrated herein, and does not seem to be of much validity. 'The Cape Mountain Zebra is found in the mountain ranges in small herds, feeding on grass, herbs, small bushes, \&c., and is only still in existence owing to its rigid 


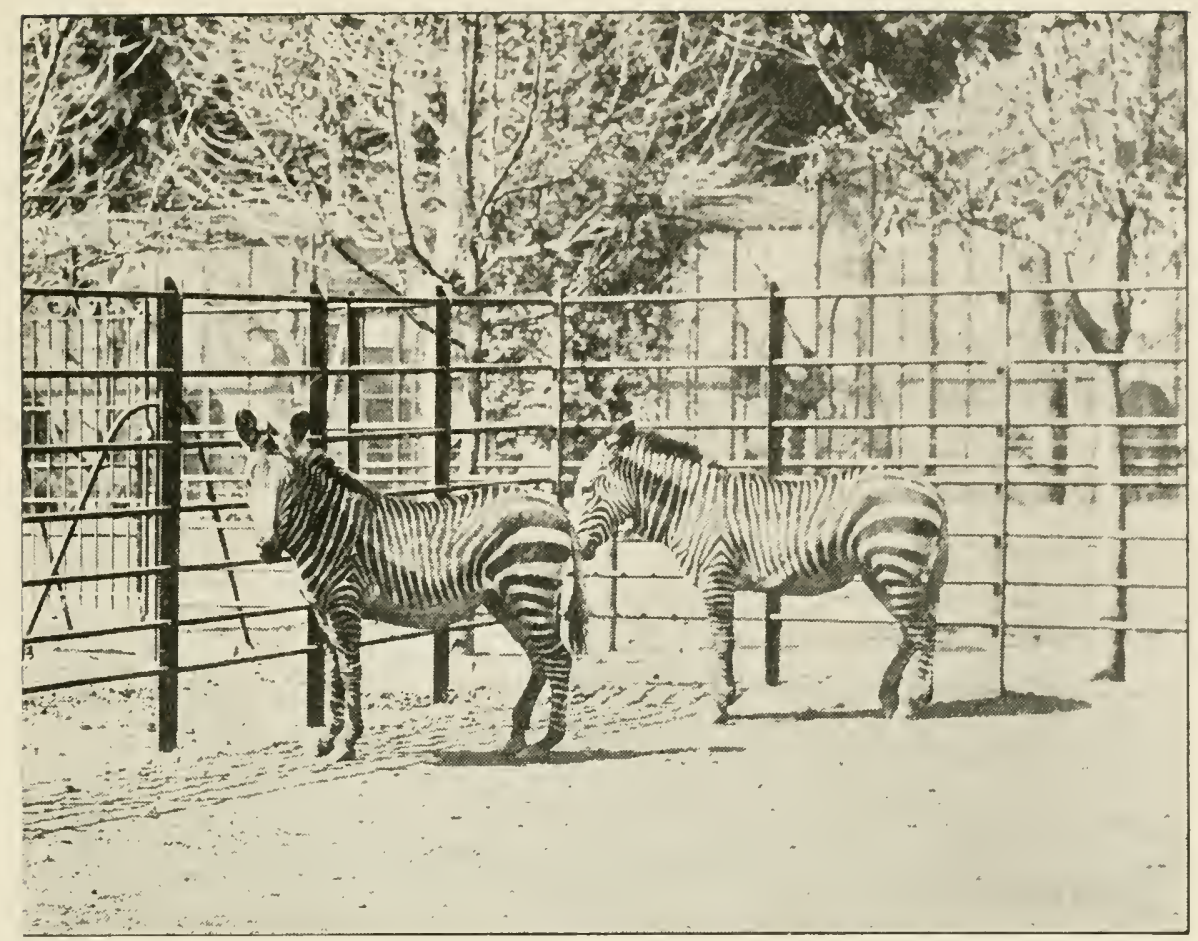

FIG. 65.-Cape Mountain Zebras.

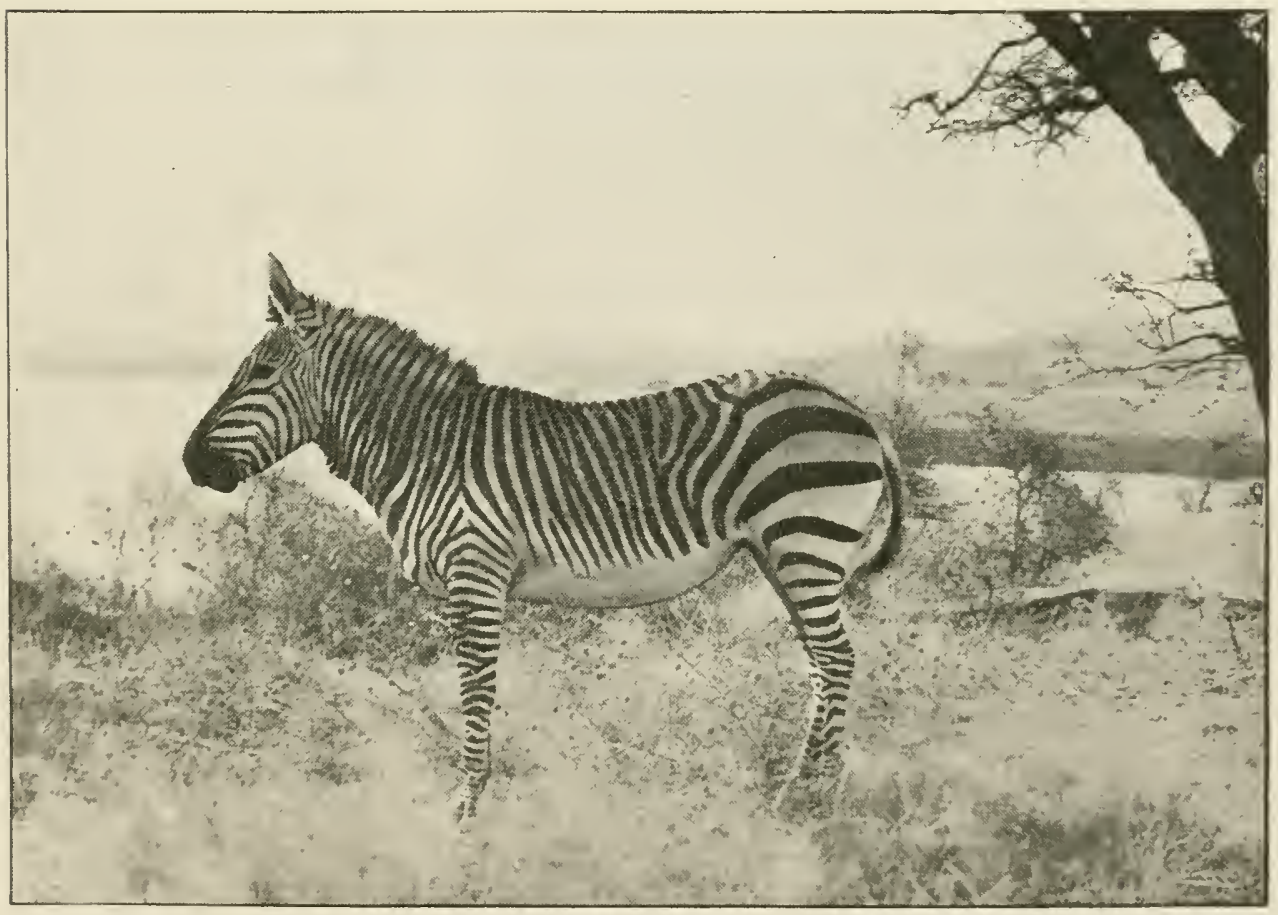

FIG. 66.-Mountain Zebra-South. West variety. 
protection by the Cape Government. Probably not more than five hundred are still in existence, and the National Zoological Gardens has to pay a heavy price for a pair nowadays. It is captured by being galloped down and "cut out" of the herd with the aid of mounted men. Owing to the mountainous and rocky nature of the animal's habitat, this method is both costly and dangerous, men and horses becoming injured.

\section{Sub-Order ARTIODACTYLA.}

Dentition usually 44 teeth: Incisors 3-3, canines 1-1, premolars 4-4, molars 3-3, molars and premolars dissimilar. Nineteen dorso-lumbar vertebræ. This is the largest group of living Ungulates.

\section{Family SUID王.}

This family includes the Pigs, whose chief characteristic to the layman may be said to be the curious flat disc-like extremity of the snout or nose. There are two pairs of hoofs on each foot, the rearmost not touching the ground.

Incisor and canine teeth present in both jaws. Nammæ abdominal. Living species confined to the Old World.

\section{Genus POTAMOCHOERS.}

Ear's pointed and ornamented with tufts or pencils of hair. Sides of body hairy; no warts on the face.

Potamochœrus chœropotamus. Bushpig. Bosvart.

Ngulubi-e'-Tschlati (literally Pig of the Thickets), Swazi.

General colour varying from greyish to reddish brown, usually darker on the sides and paler along the back. Snout whitish. Tail tufted with black hair. Body fairly 
well covered with bristly hair. The young are striped. Length $4_{4}^{1}$ feet. Height about $2 \frac{1}{4}$ feet.

This animal ranges from Swellendam in the Cape, along the eastern portions of South Africa to Northern Rhodesia; and frequents bush-covered hills or flats where there is plenty of water. It feeds upon roots, bulbs, wild

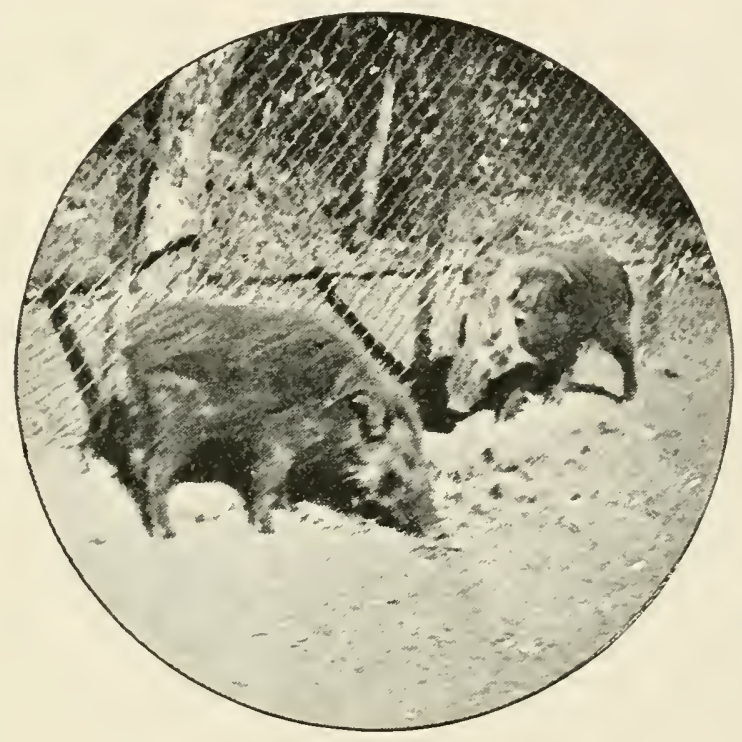

FIG. 67.-Busbpigs.

fruit, \&c., and goes about in droves of from six to a dozen individuals; it is chiefly nocturnal in habits. In the Eastern Transvaal Bushpigs are a source of much annoyance to the farmers, devastating the cultivated lands at night, devouring and digging up the crops. Kirby says the flesh is coarse, but many hunters have told me that the meat is preferable to that of the IVarthog.

\section{Genus PHACOCHCERUS.}

The face is disfigured by two pairs of warty growths, which are considerably more developed in the male than in the female. Sides of the body nearly naked, being but 
sparsely haired. Ears broad and more rounded than those of the Bushpig. 'The upper canines grow outwards and upwards, sometimes attaining in the male a length of 10 inches. 'The lower canines project, upwards and form strong and sharp weapons.

Phacochœrus æthiopicus. Warthog. Vlakvarti.

Colour of skin greyish-black, the sides of the body being only sparsely clothed with bristles. There is a

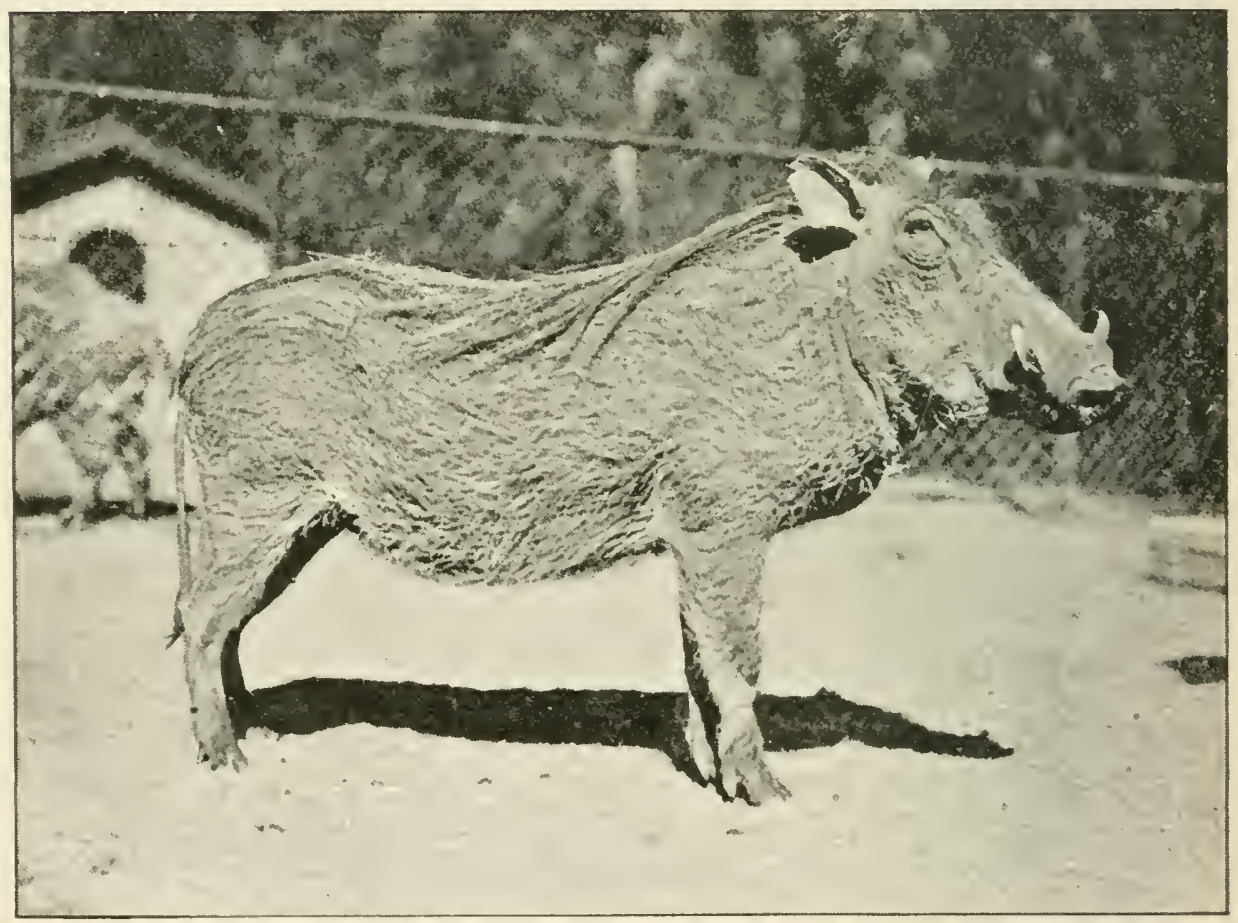

Fig. 68.- Warthog Sow.

fairly long mane-like growth of hair along the back, from between the ears, which is brown or black in colour. Tail short, naked and tufted with black bristles. There is a prominent white whisker-like tuft of hair on each cheek. Length of male about $4 \frac{1}{2}$ feet; height $2 \frac{1}{2}$ feet. 
The female is smaller and has much smaller warts. The weight of a sow 7 years old in the Zoo is 100 lbs. At present the Warthog ranges from Zululand through the Eastern and Northern Transvaal, and Portuguese East Africa, to Rhodesia and beyond. It inhabits somewhat open weli-watered country, feeding on the plains in small herds or family parties in the evenings and early mornings, and retiring to thickets or other suitable cover during the heat of the day. It is a peculiar fact that the Warthog usually drinks about midday. When pursued it has often been known to take refuge in an Aardvark or other convenient burrow. From three to eight young ones are produced at a birth, although four would appear to be the more usual number. When running they hold the tail erect, presenting a somewhat comical appearance. While feeding or rooting up the ground they go down on their knees, which have in consequence naked pad-like patches. They get very tame in captivity, although the writer once had an unpleasant experience with a half-grown Warthog. This animal had broken out of its box while being conveyed from Livingstone by rail, and for over an hour resisted all attempts to return it to its cage, charging with malice aforethought time after time, when an undignified scramble on to the side of the railway truck was our only defence. The animal was eventually secured by the aid of several sacks and the help of some white men.

Although writers and hunters state that the flesh is unpalatable, we have eaten young Warthog and found it quite tasty. 


\section{Family HIPPOPOTAMIDÆ.}

Bulky animals, with a broad head and square mouth, four toes possessing nail-like hoofs, all of which rest on the ground; and a thick skin almost devoid of hair.

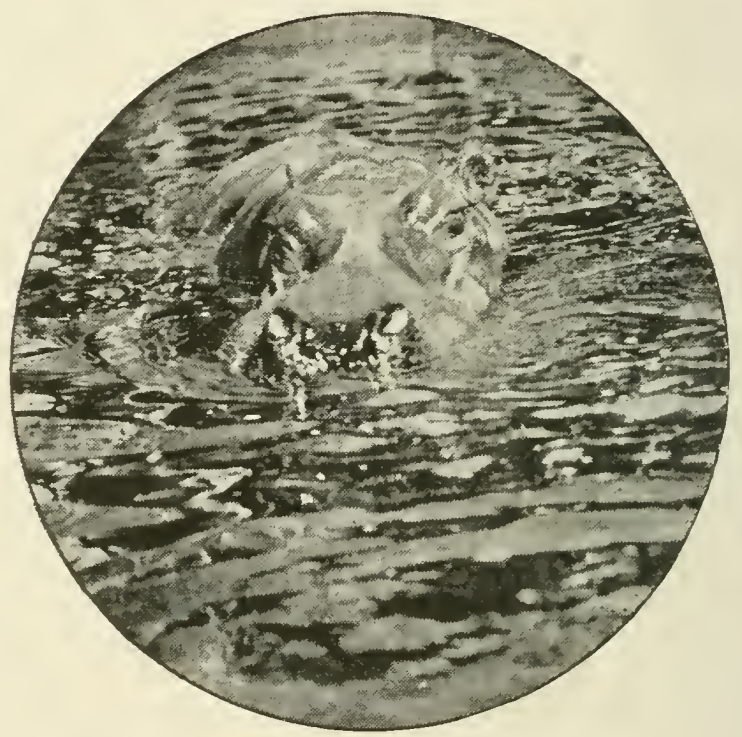

FIG. 69.-Hippo Resting in the Water.

Canine teeth long and curved. Semi-aquatic, herbivorous animals. Permanent dentition: Incisors 2-2, canines 1-1, premolars 3-3, molars 3-3. Milk teeth: Incisors 3-3, canines 1-1, molars 4-4. Nammæ inguinal.

\section{Genus HIPPOPOTAMUS.}

Hippopotamus amphibius. Zee Koe.

Form heavy and rather pig-like. The head is large with the mouth square and the nostrils situated on top of the muzzle; skin smooth with hairs only on the mouth, on the sides of the head and neck, on the short stumpy ears, and at the end of the tail. Legs and tail short. General colour black or slaty black, inclining to a fleshy 
tinge on the belly. There is a thick layer of fat between the body and the skin.

Length from 10 to 12 feet. Height about $4 \frac{3}{4}$ feet.

Although found throughout the sub-continent in the early days, the Hippo is now practically extinct south of the Eastern Transvaal and Zululand. In the Zambesi region it is still fairly common. Several small herds still

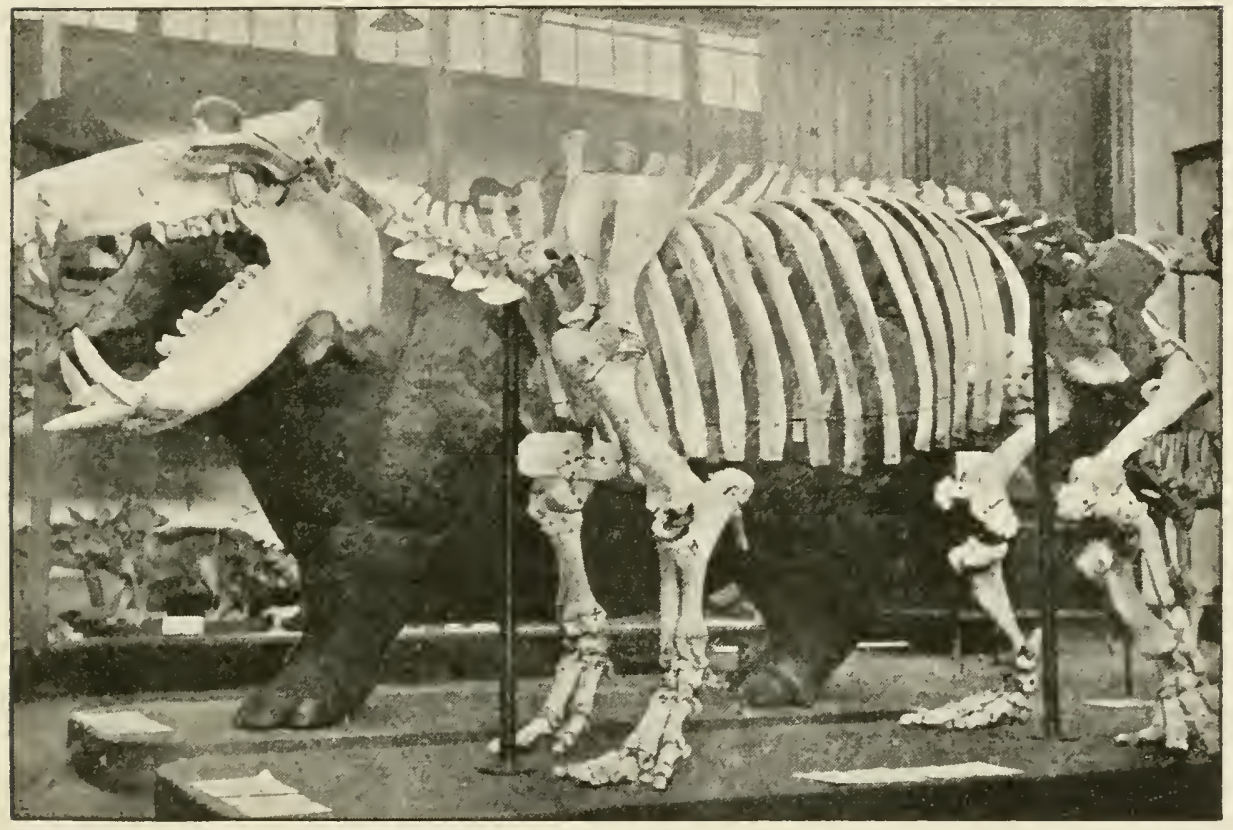

FIG. 70.-Skeleton of Hippopotamus

(from a mounted example in the Transvaal Museum).

linger in the Komati and Sabi Rivers in the Eastern Transvaal, where they are strictly preserved. They are still fairly common in the Maputo and Inkomati Rivers of Portuguese South-East Africa.

The Hippo, which is confined to the African continent, lives for the most part in the water, landing only at night to feed upon grass, branches, reeds and rushes. Its call is a series of curious roaring grunts.

Only one young one is born at a time, which while in 
the water is carried on its mother's back. It will lie in the water with only the top of the head showing, or

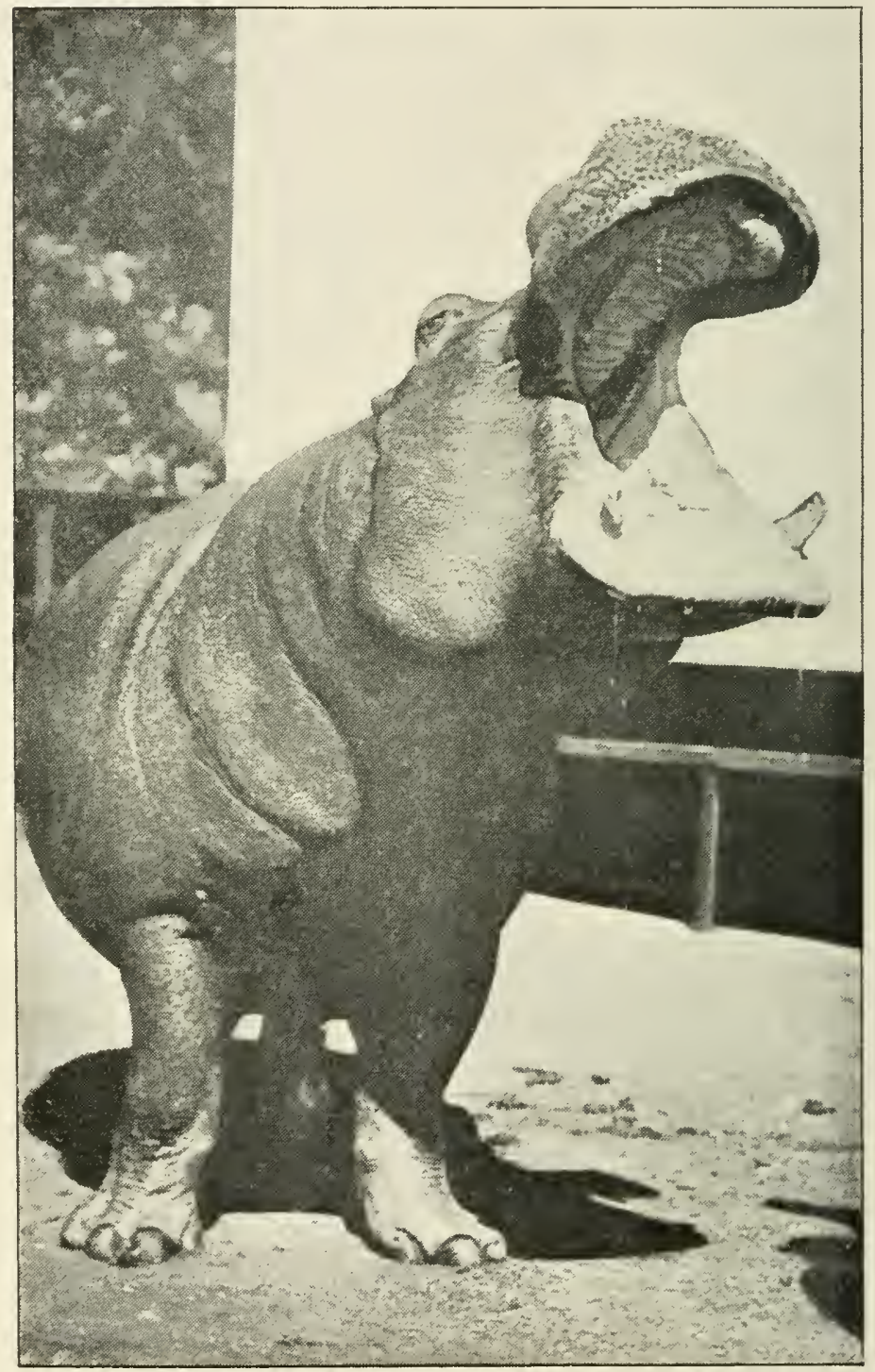

FIG. 71.-Bull Hippopotamus.

very often only the eyes and nostrils, both of which can be closed at will. It will sometimes lie on the bank of a river or lake and bask in the sun, if undisturbed, but the position in the water above described is the more 
usual; it will even lie on the bottom of a river-bed, coming up now and then to breathe.

Accidents have occurred to boating parties in rivers frequented by Hippo, on account of these animals upsetting the boats.

The flesh is said to be good eating. 'I'he fat is much prized by the natives. The whips or sjamboks valued so

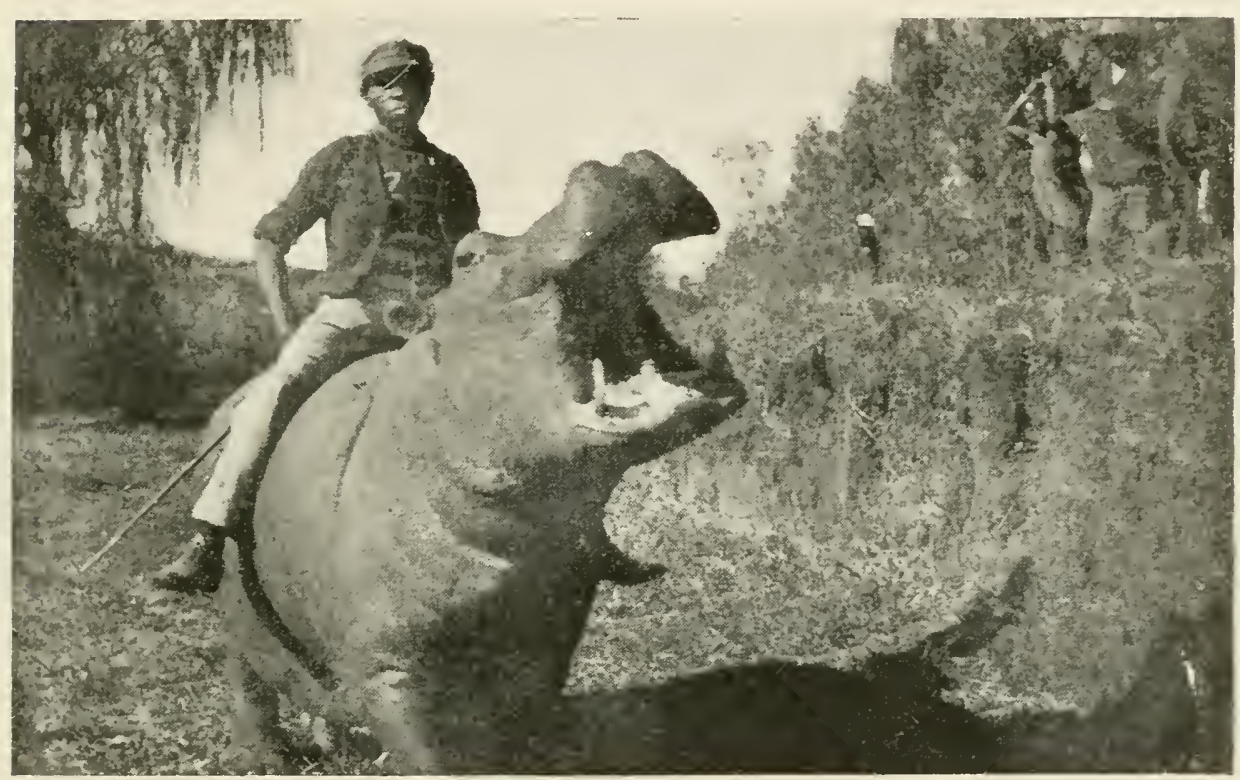

Frc. 72.-Young Hippopotamus.

much in South Africa are made from the thick hides of the Hippo or Rhinoceros.

There is a bull in the Pretoria Zoo which was presented by the late Chief Lewanilia of Barotseland to Lord Selbourne-then Governor-General of South Africa-and by His Excellency to the Gardens in 1907 . This animal has periodical fits of rage, not unlike the "must" period of a bull elephant, when he attacks the door of his house, and the iron rails of his camp until his mouth is dripping with blood. He is, however, respectfully docile 
with his own particular black "Boy" who feeds and looks after him, although peculiarly enough, strange nativesespecially women-excite him. "Sigapo," as he is named, can be coaxed out of the water by his native keeper almost at any time, by the offer of bread, or cakes of mealie porridge of which he is inordinately fond. Should these lures fail, as they sometimes do when he has a fit of the blues, the forcible introduction of a strange Kaftir

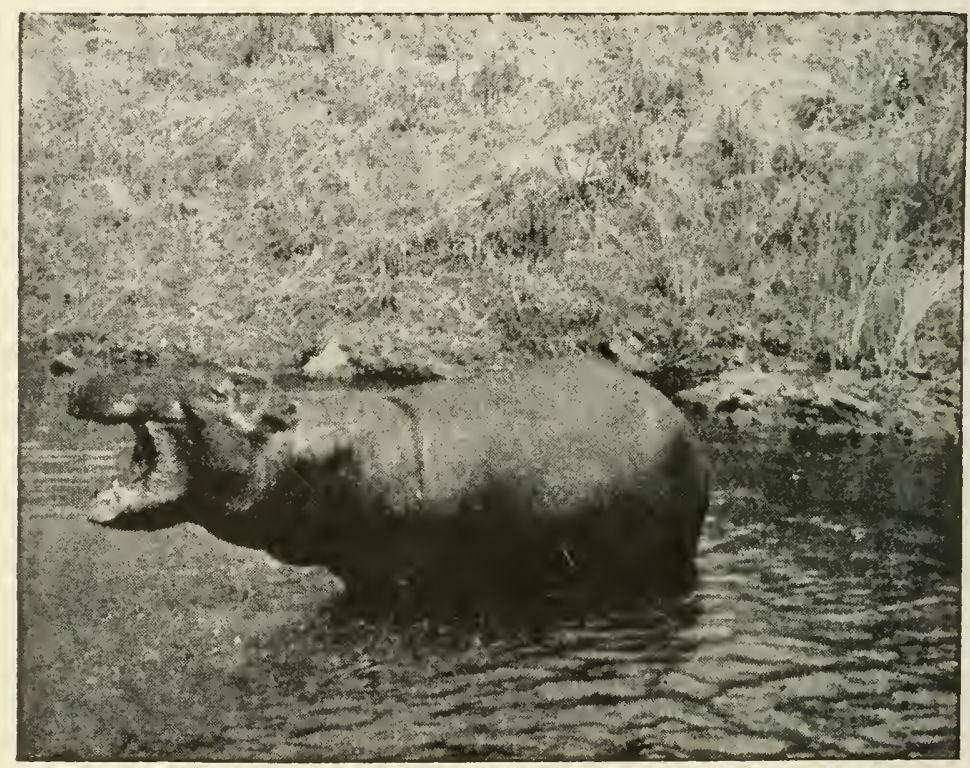

FIG. 73.-Hippo Wading.

within his camp has the desired effect, much to the dismay and terror of the said native. In his younger days shortly after his arrival in the Zoo, he used to daily follow his native attendant to the river for a bathe, until he chased our blacksmith and nearly frightened the man out of his wits. After this little escapade he was sentenced to imprisonment for life and a concrete tank was built for him instead. We nearly lost him twice, firstly when a thoughtless individual threw a stone, nearly two inches in diameter, down his throat, which he subsequently 


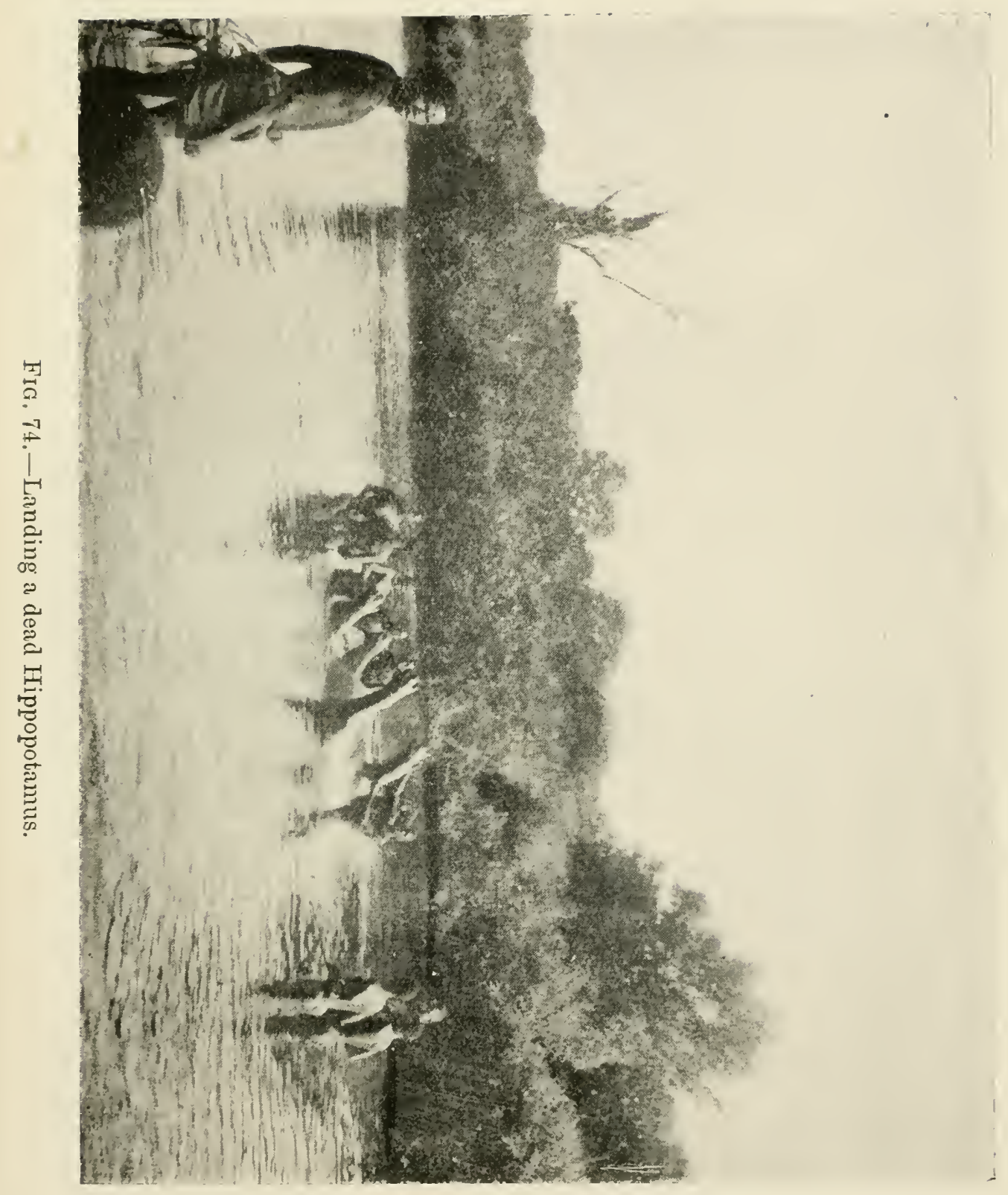


passed with great difficulty, after being a very sick hippo for some days; and secondly when another maniac threw an empty soda water bottle into the back of his throat, which his native attendant pluckily extracted before the animal had a chance to chew or swallow it. It seems incomprehensible that grown men can perpetrate such idiotic-not to say cruel-acts against a defenceless creature.

\section{RUMINANTIA.}

These are the Artiodactyle Nammals, more commonly known as ruminant animals which "chew the cud," and which are united under the above name. These possess a complicated stomach consisting of four chambers-the rumen, the reticulum, the psalterium and the abomasum. The food taken in by the animal passes into the rumen and reticulum, and remains there until it has eaten enough, when it chews the cud, i.e., it "vomits" portions of the food into its mouth, where it is re-masticated and again swallowed, passing this time along the grove of the paunch, and entering the psalterium, through which it passes into the abomasum, where it is properly digested.

The Pecora or Cotilophora is a group containing the horned ruminants such as the Deer, Giraffe and Antelope, and which have no incisor or "front " teeth in the upper jaw.

Family GIRAFFIDE.

\section{Genus GIRAFFA.}

Tall animals with long legs and enormously long necks; higher at the withers, i.e., with downward sloping backs. On the head are a pair of erect borns (as they are usually called) covered with skin. These have a bony core, which are at first separate from the skull, but later in life 
become united to it. False hoofs absent. Dentition: incisors $0-3$, canines $0-1$, premolar's $3-3$, molar's $3-3$, total $=32$.

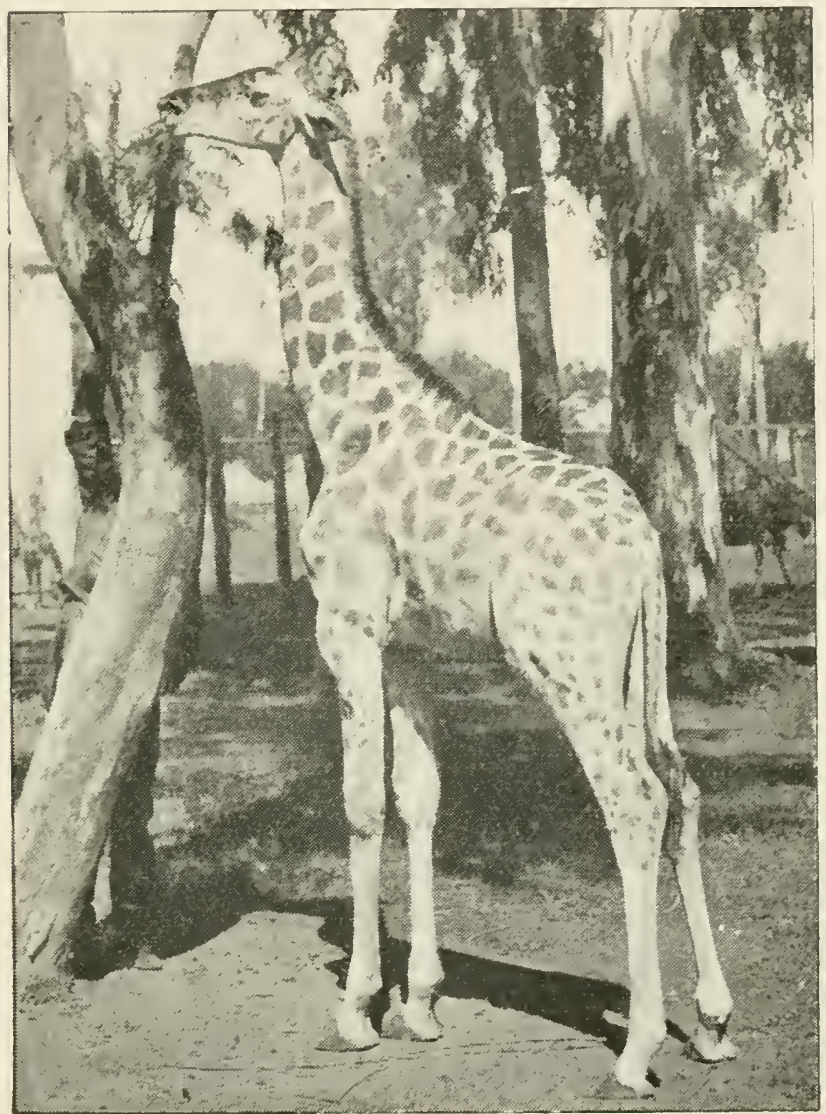

FIG. 75.--Southern Giraffe.

Giraffa capensis. Southern Giraffe. Kancel.

Native names: 'Tuthla (Basuto); Ihuhla (Zulu); Indhlubamiti (Swazi).

The colour is pale tawny yellow or pale yellowish brown, marked with large irregularly-shaped blotches of yellowish or dark-brown. The spots on the legs are smaller and paler. There is a short upstanding mane on the necti, which is of a chestuut-brown colour. The height of a 
mounted male in the Transvaal Museum from the top of the head to the hoof is 18 feet 6 inches, but Bryden gives 18 feet $11 \frac{1}{2}$ inches as the largest measured by him. Females seldom measure more than 16 feet. At present the Giraffe is found in the Northern Kalahari, in adjacent

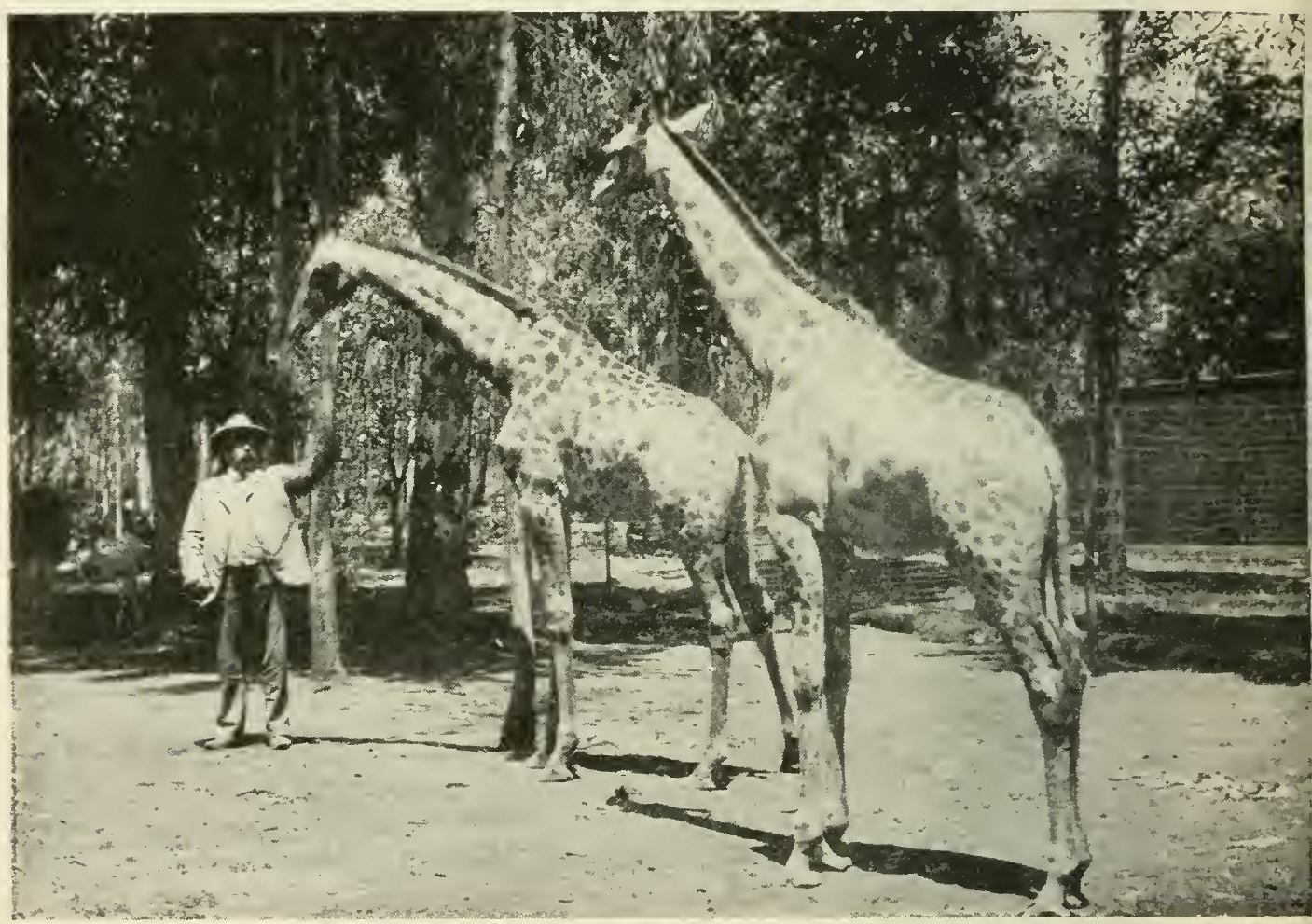

Fig. 76.-Southern Giraffes.

ex-German territory, and in North Western Rhodesia. A few also inhabit the Sabi Game Reserves of the Eastern Transvaal and Mozambique.

Giraffes are found in fairly dry country, interspersed with sandy hills clothed with Kameel-doorn bush and other dry land shrubs. They are found in troops of from half a dozen to several dozen individuals, feeding in the early part of the morning or in the evening. They have no great pace, when compared with that of a good 


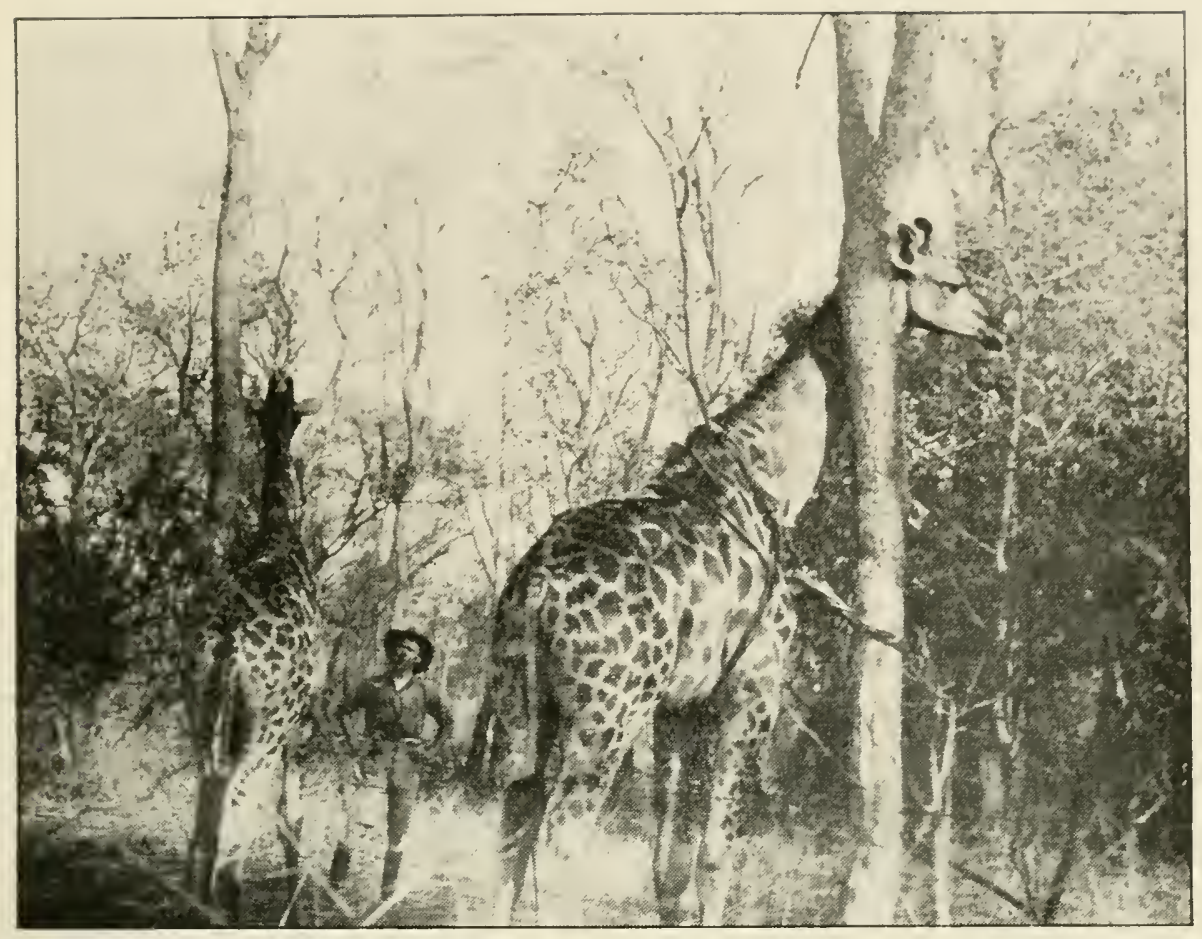

FIG. 77.- 1 Iethod of tying newly-captured Giraffes to trees.

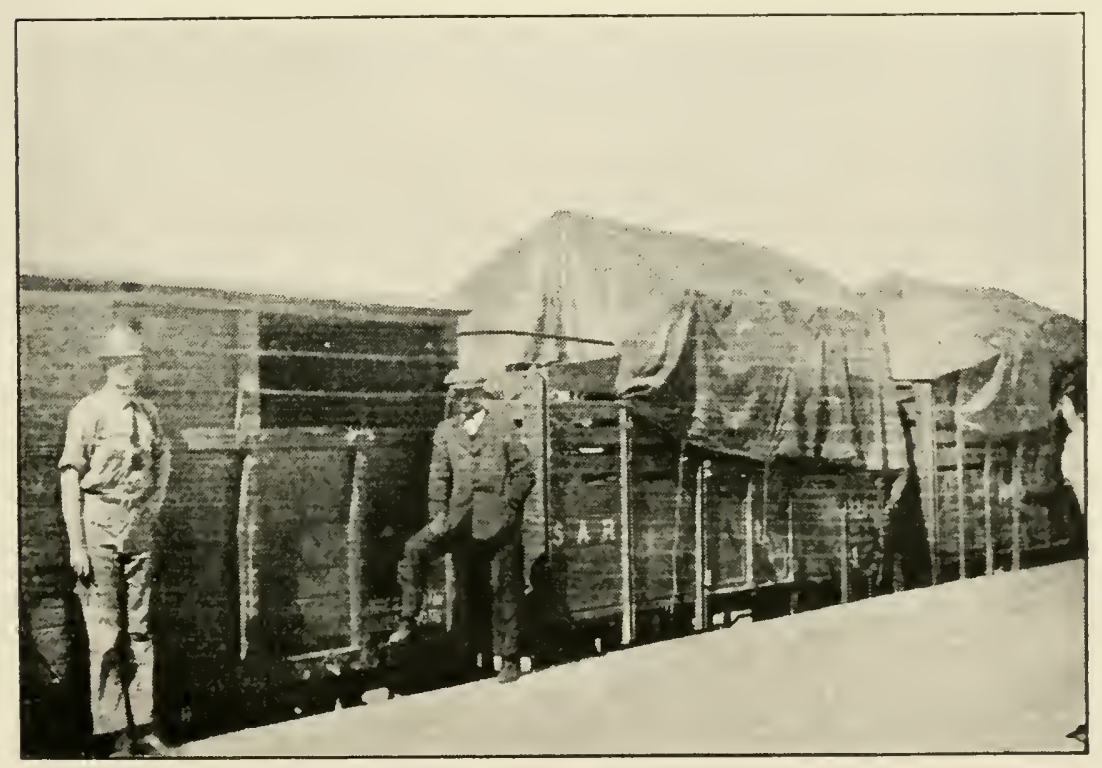

FIG. 78.- Wild animal caravan: Giraffe trucks on right. 
horse, although it takes some time to run them down. They lift the front and hind legs of one side at the same time, their gait therefore resembling that of the Camel.

Their food consists almost exclusively of the leaves of the acacias, such as the Mimosa and Kameel-doorn.

One calf only is as a rule produced at a time, fourteen months being the period of gestation. Old males have a powerful odour. The giraffe is mute, but enjoys excellent sight and hearing. It is a harmless, inoffensive animal.

These animals have bred well in the London Zoo, but we have had no luck with them, losing them fairly rapidly, probably on account of the "rumning down" to which they are subjected in capturing. Several have died of congested lungs, and others of debility-but these latter were badly infested with cysticercus, which of course saps the strength of the animal. We have at present in the collection a bull nearly seven years old, which was received in 1912 from Chief Khama of Bechuanaland, when about a quarter grown. This animal has been healthy and playful ever since he arrived and was captured when young and hand-reared by the natives. For a year after we got him he would drink a small pailful of milk twice a day.

Family BOVID王.

Horns, when present, consisting of a bony "core" attached to the skull, and covered by the "horn" or sheath, which is a hard epidermal fibrous structure. Dentition similar to that of the giralfe. 'I'his family contains the true antelopes, which range from the diminutive Bluebuck to the lordy Eland. 


\section{Sub-Family BUBALINA:。}

\section{Genus BUBALIS.}

Large antelopes with a long narrow head, and sloping back, standing higher at the withers than at the rump. Gland below the eye small. 'Tail long and reaching to below the hocks. Both sexes are horned.

The Hartebeests live in small herds on the open veld and are suspicious and wary animals, with excellent

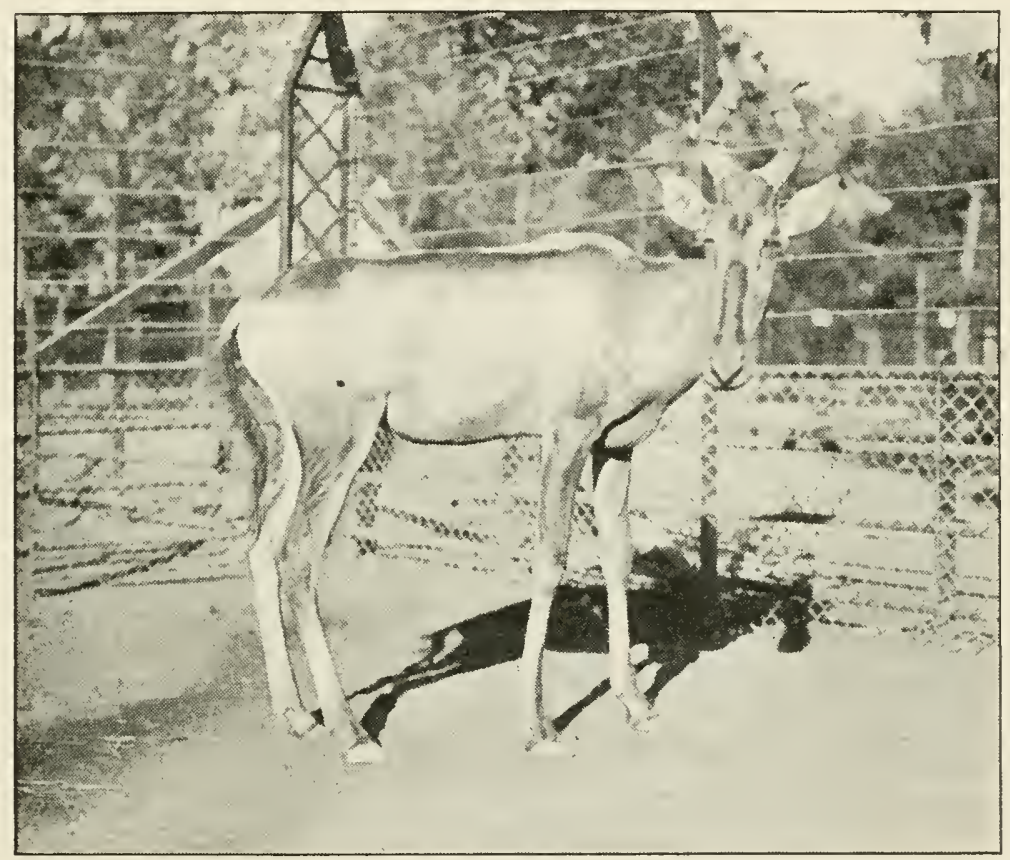

Fig. 79.-Red or Common Hartebeest.

Bubalis caama. Red Hartebeest. Rooi Hartebeest.

Native names: Khama (Bechuana); Igama (Makalaka).

powers of speed. The flesh is not considered very tasty. As a rule only one calf is born at a time. They are day feeding animals.

Colour dark fulvous or rich brown, with black markings on the front of the face; a dark line along the ridge of the neck, down the front of the legs and on the shoulders 


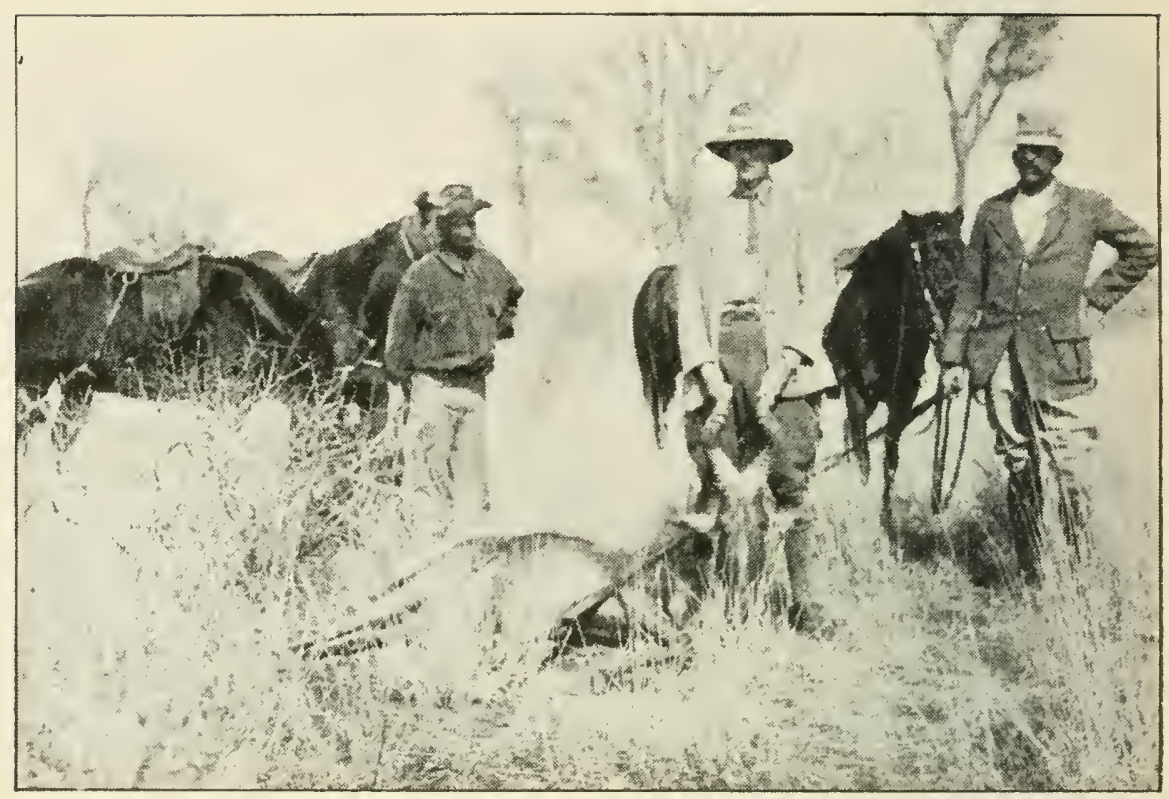

FIG. 80.-Common Hartebeest.

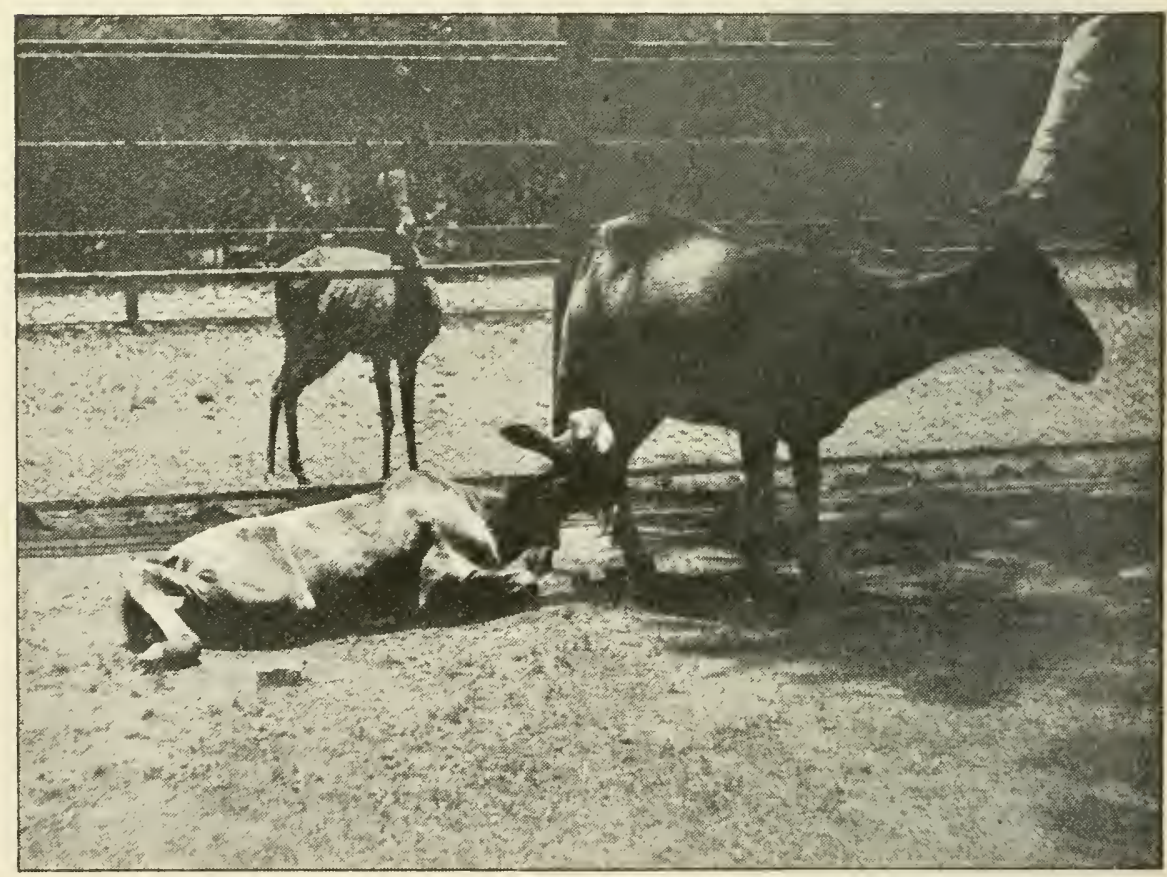

FIG. 81.-Foung Hartebeest suckled by a Goat. (Vaal Rhebok in background.) 
and thighs. Considerably paler (almost white in some individuals) on the rump and along the belly. Fars long and pointed, whitish on the inner surface. Tail fringed with black hairs. The female is smaller and often paler than the male. Young animals possess straight horns, and have no black markings, and look even more stupid than the adults. Horns V-shaped as seen from the front, bent slightly outwards, then inwards, forwards and the terminal third backwards. Length about $7 \frac{3}{4}$ feet. Tail 22 inches. Height at shoulder 4 feet. Horns 19-25 inches. Two records of 26 inches.

This animal once roamed over the whole of the Cape Colony but is now only found in Little Namaqualand; north of the Orange River it is fairly common in Bechuanaland from the Kimberley District to Lake Ngami. It is also found in the north western corner of the Orange Free State, Natal, the Western Transvaal, and once inhabited Basutoland, although it is doubtful if any survive to-day in that locality.

Bubalis lichtensteini. Lichtenstein's Hartebeest, Mof or Vaal Hartebeest.

Native names: Inkulando (Mashona); Kolotombini (Barotse); Konzi (Chilala).

Size and form much like the Common or Red Hartebeest, but the colour a brighter fulvous, with the sides of the body paler, and almost white below. Chin and the upper part of the head, before and between the horns, black; no black on the face and behind the shoulder, although the black edging on the cannon bones of the leg is conspicuous. Rump and tail as in B. caama. The horns are much flatter at the base, are much lower" set" than the common species, and only the flattened basal portion is ringed. The older the animal the more the 
points of the horns diverge. Length 15 to 20 inches. Records $22{ }_{4}^{1}$ and 23 inches. Height at shoulder 50 to 52 inches. Weight about $400 \mathrm{lb}$.

Lichtenstein's Hartebeest is only found from the Northeastern 'Transvaal ${ }^{1}$ and Central Rhodesia to the central

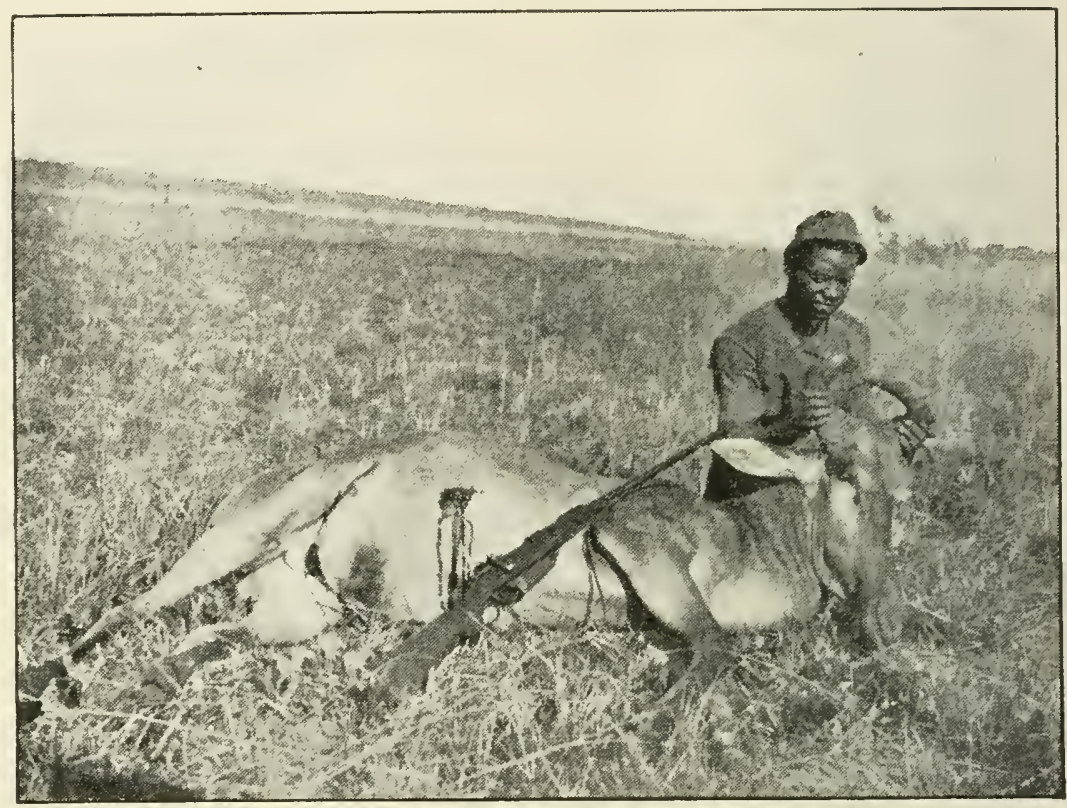

FIG. 82.-Lichtenstein Hartebeest.

coastal tract on the East, Nyasaland in the centre and Barotseland and North-western Rhodesia on the West.

Although wary animals, when one is wounded or killed, the others gather round and can then easily be shot. It has a peculiar habit of standing on the tops of termite heaps to look round the country.

Damaliscus pygargus. Bontebuck. Bontebok.

The Bontebok is of a rich purplish brown colour, paler on the shoulders and the middle of the back, and darker on the sides and on the upper portions of the limbs. The

${ }^{1}$ It is doubtful whether any exist in the Transvaal to-day. 


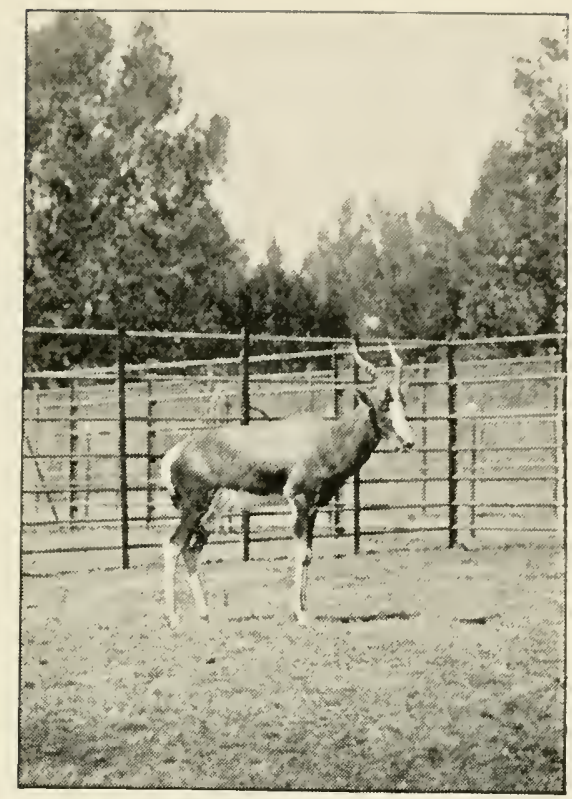

FIG. 83,-Bontebuck Ram.

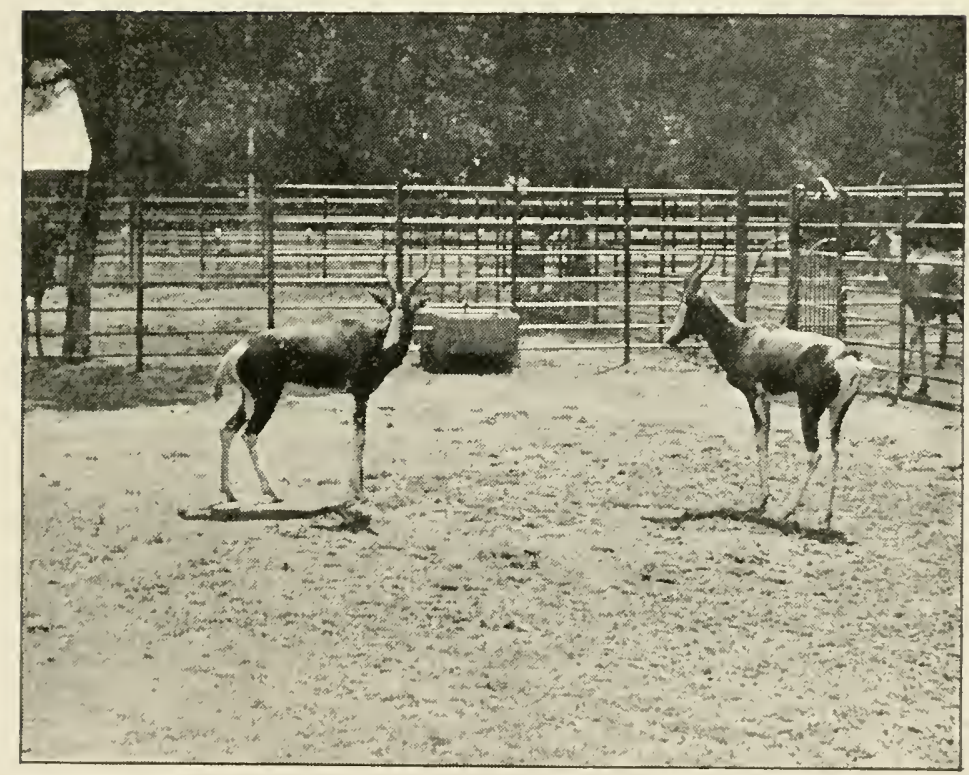

FIG. 84.-A pair of Bontebuck. 
belly is white, sharply defined from the dark sides; the rump is also white, as well as the insides of the limbs and the outsides of the lower half. A white blaze commences between the horns, and spreads over the face to the tip of the nose. The horns are curved outwards and backwards, the terminal third slightly inwards and forwards, and ringed with twelve or thirteen transverse ridges. They resemble those of the Blesbok, but are much darker in coloration. Length 12 inches to 16 inches; record $16 \frac{3}{8}$ inches. Length of the head and body 5 feet; tail about 18 inches, including the tuft of hair. Height at shoulder about 3 feet 3 inches. Weight about $200 \mathrm{lb}$.

This antelope may be said to be extinct as a truly wild animal, existing only in a semi-domesticated condition on some farms in the Bredasdoop district of the Cape Province belonging to the Albertyns and Myburgs. The young are born during the months of August and September.

I think the least the Cape Provincial Government can do is to proclaim a reserve for the preservation of this animal, before it becomes totally extinct.

Damaliscus albifrons. Blesbuck. Blesbot.

(Nunni of the Bechuana.)

This species resembles the previous one, except that the colour is slightly redder and the white rump patch is smaller. Moreover, the outsides of the limbs below the knees and hocks are not white, as in the Bontebok. The white blaze on the forehead is divided by a brown line. The horns are of a pale horn colour, or are brown with the ridges of the rings horn colour, and not altogether black as is the case with its almost extinct ally. Length, 12 to 
18 inches (record, $18 \frac{5}{8}$ inches for the male, $16 \frac{1}{2}$ inches for the female); height about 3 i feet.

In days gone by the Blesbok roamed over the veld in large herds, consorting with the Springbuck, although now it only exists in flocks of from ten to a couple of hundred individuals on certain farms in the Orange Free State, Transvaal and Bechuanaland, and on one farm in the Steynsburg District of Cape Colony.

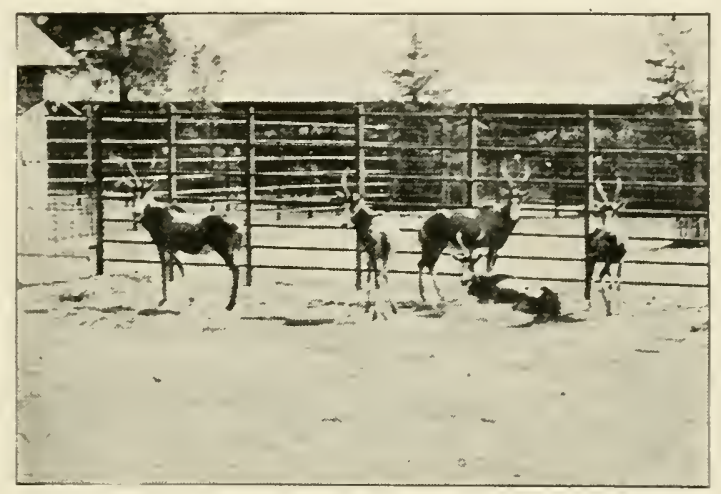

Fig. 85.-Blesbuck in the Zoo.

I saw in May, 1918, on a farm in the Marquard District of the Orange Free State, over 1,000 Blesbuck, which were very wary and shy, and which were well preserved by their owner, the late Mr. Dirk Uys. There is also a fine herd of about 1,000 in the Pretoria district, preserved on the farm of Mr. Hans Erasmus, of Rantjesfontein.

A number are captured every year for restocking other farms, and the Zoo. The animals are driven into a "drive" of wire-fencing on the veld, which gradually narrows until the converging fences lead into the catching pen.

The Blesbuck resembles the Bontebols in habits, roaming about the open veld, feeding upon grass, herbs, \&c., and being of a wary nature. It is a very fast animal, but 


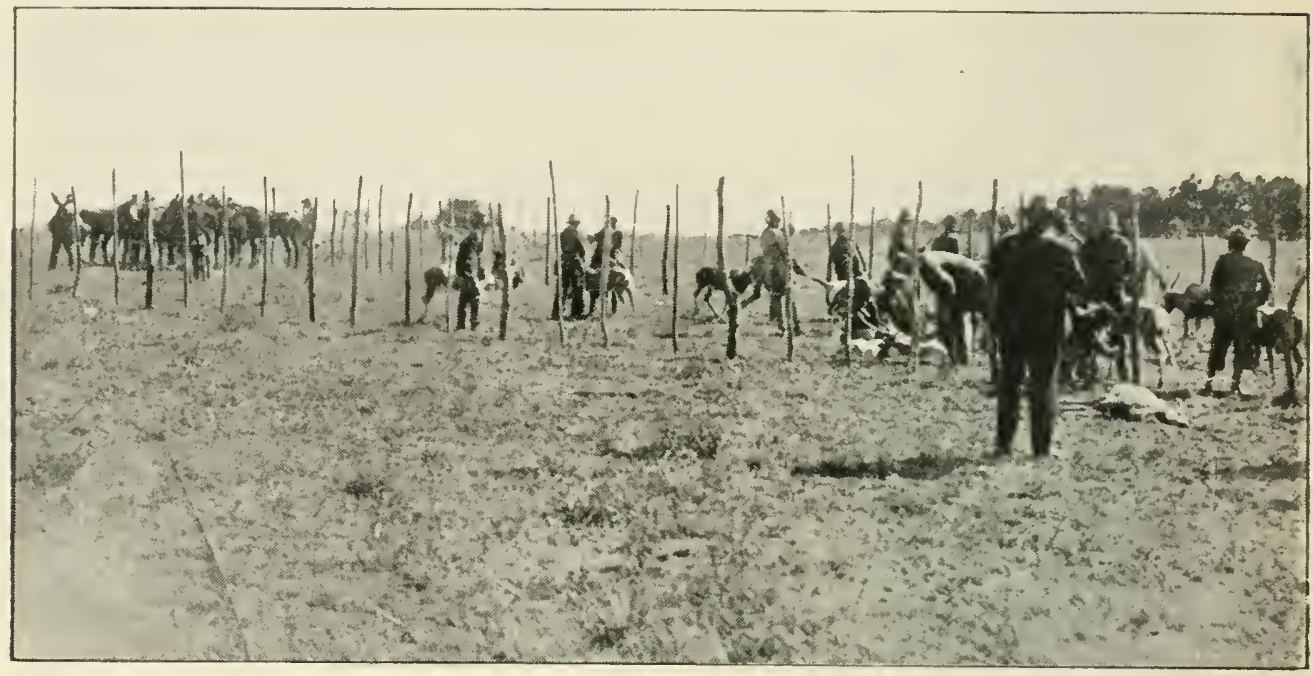

FIG. 86.-Capturing Blesbuck on Rantjesfontein.

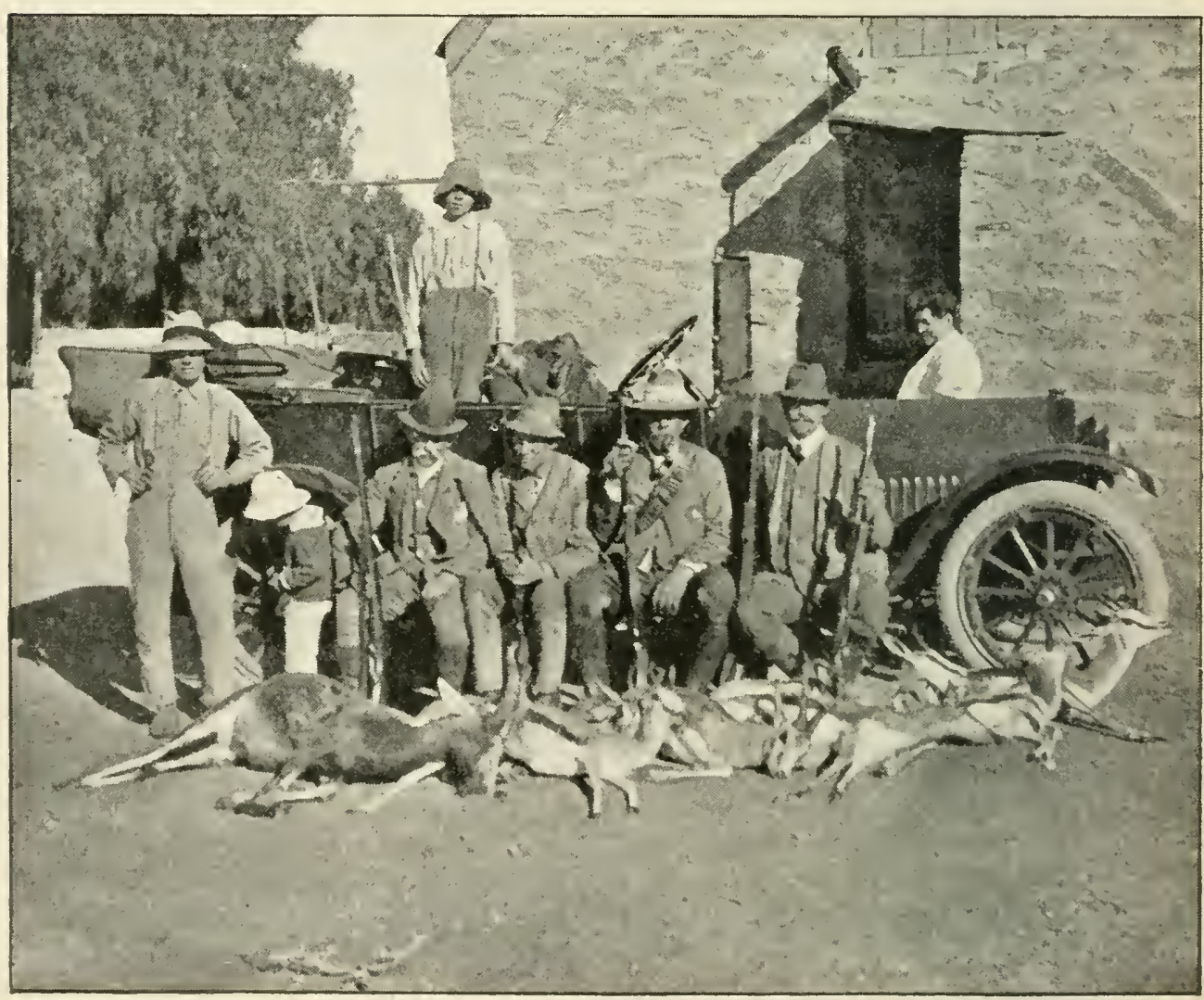

FIG. 87.-Blesbuck and Springbuck shoot in the O.F.S. 
does not jump like the Springbuck. Only one young one is born at a time, usually in early spring. 'The flesh of the Blesbuck is delicious eating. 'The method of shooting them is much like that for the Springbuck.

Damaliscus lunatus. Sessaby or Tsessebi. Bastard Hartebeesi.

Native names: Mcolomo (Matabele); Kaboli (Barotse); Mzanzi (Swazi and Zulu).

One other nember of the genus remains to be mentioned, the Sessaby or Tsessebi. In colour it is of a

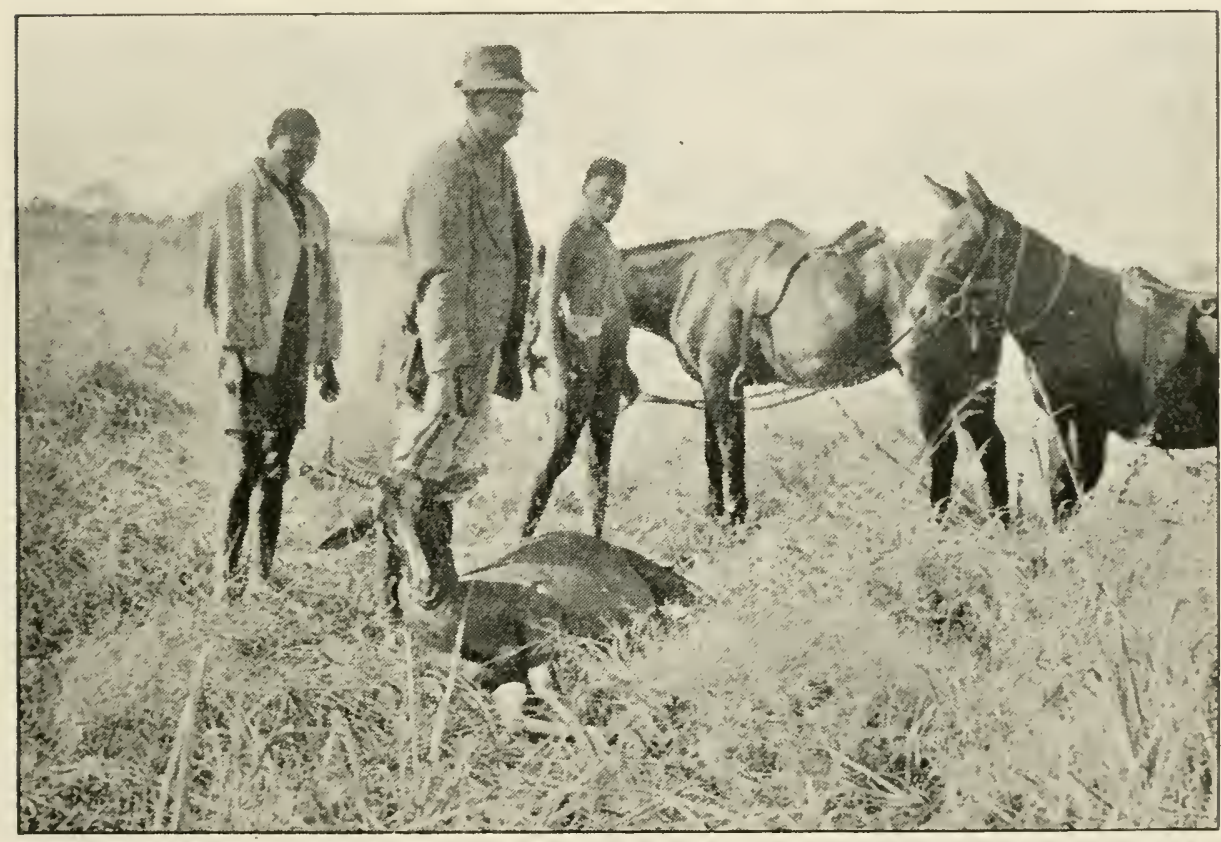

FIG. 88.-Sassaby or Tsessebi.

chocolate brown, changing to slatey brown in certain lights, and appearing parti-coloured as a rule, the lustre in the skin resembling that of shot silk or satin. The face, upper portions of the legs and the tail are black. The horns are short, almost $U$-shaped as seen from the front, 
bent obliquely outwards, with an upward and backward curve. Length, from 15 to 17 inches; record, male $17 \frac{1}{2}$ inches, female 16 inches; height at shoulder, about 3 feet 9 inches.

The Sessaby replaces the Blesbok in Rhodesia, Northern Transvaal and Eastern Transvaal and Portuguese East Africa. The Zoo has had examples from the Sabi Game Reserve. It has the reputation of being the fastest antelope in South Africa.

\section{Genus CONNOCHAETES.}

The head is massive, with a broad muzzle, which is clothed with bristles; nostrils wide apart, large and hairy inside. Neck adorned with a mane. Horns expanded at the base, and without rings.

Connochaetes taurinus. Blue Vildebeest. Blaanu Wildebeest.

Native names: Inkongoni (Swazi and Zulu); Kokong (Barotse) Ikokoni (Basuto).

Colour bluish-grey or grey-brown, distinctly marked with dark transverse stripes on the sides of the body. Face nearly black. A mane of black hair, and tufts of the same below the jaw and on the throat. Tail furnisher with a long black tuft of hairs. Length of head and body, 7 to $7 \frac{1}{2}$ feet; tril, 3 feet; height at shoulder, 4 to $4 \frac{1}{2}$ feet. Horns of the male, 20 to 24 inches along the front curve; females shorter; record, 31 inches. Record width, widest outside measurement, $32 \frac{1}{2}$ inches (owners' measurement, $33 \frac{1}{2}$ ). Weight, 500 to $600 \mathrm{lb}$. A bull weighed by Dr. Schoch was $515 \mathrm{lb}$.

It ranged formerly from the Northern Cape Colony to the Zamkesi, but is now only found as far south as the 


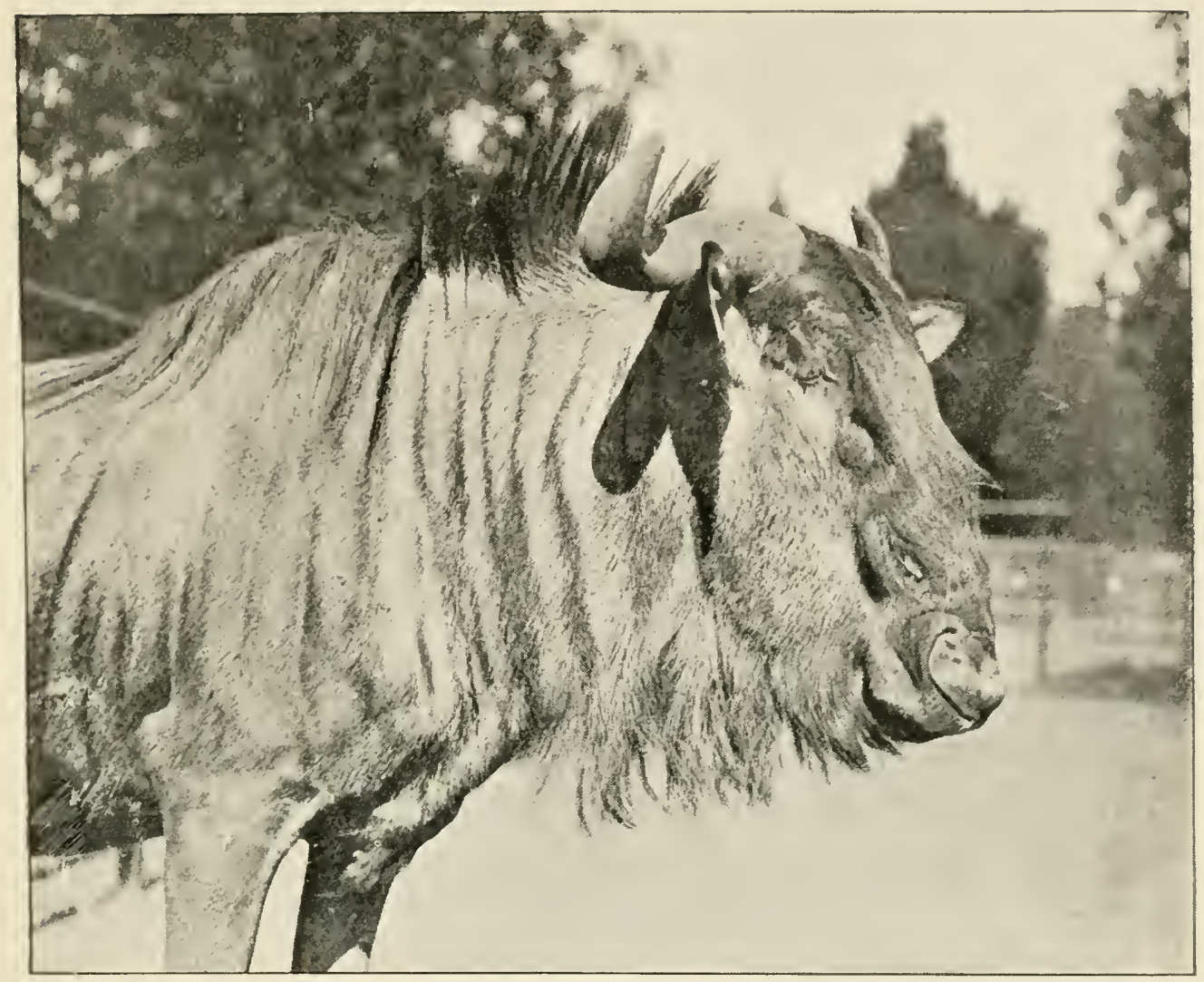

Fig. 89.- Blue Wildebeest or Brindled Gnu.

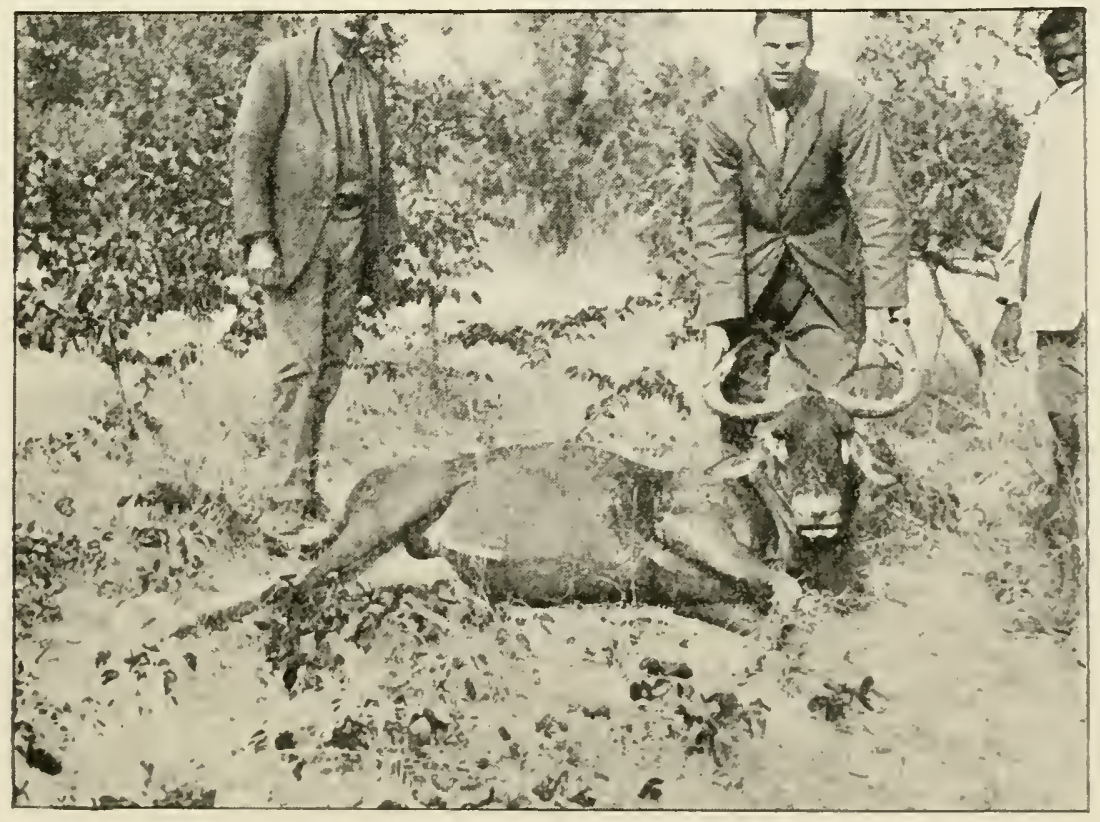

Fig. 90.-Dead Blue Wildebeest. 
Kalahari and ex-German territory on the west and Northern Zululand on the east. In North-West Rhodesia and the Eastern and Northern Transvaal it is still fairly common. It resembles the succeeding species in habits, but is often found in the open glades of bush country, and it seldom strays far from the vicinity of water. It feeds during the daytime, and usually congregates in herds of from thirty to fifty individuals, although two or more herds may stay temporarily together.

Its pace is fast, and the animal is said to have excellent staying powers. Usually a single young one is born during the months of November to January. Mr. E. Atmore, of Hectorspruit, shot a pure albino near the Lebombo Mountains in 1918.

The Zoo has had examples from Vryburg (Kalahari), the Eastern Transvaal and Southern Rhodesia. The skin, which is strong and tough, is much prized for making reims.

Connochaetes gnu. White-tailed Gmu or Black Wildebeest. Zwart Wildebeest.

The colour is dark brown. There is a patch of hair on the face, which is directed upwards. There is also long hair on the chin, throat and between the legs. The tail reaches to the hoclis, the longer white hairs sometimes reaching to the ground. Horns bent downward and forward and then upward. Length, 19 to 25 inches; record, $26 \frac{1}{2}$ inches (owner's measurement, $30 \frac{7}{8}$ inches). Length of the head and body, 6 feet; tail, about $2 \frac{1}{2}$ to 3 feet; height about $3 \frac{1}{2}$ feet.

It is at present only found in the Orange Free State (where herds are, amongst other localities, still preserved 
in the Kroonstad and IVinburg districts) and in the SouthWestern Transvaal. Like the Blesbok, it inhabits the open plains in herds of varying numbers. In May, 1918, when out shooting with our hosts, Messrs. McKechnie and H. P. Basson, we saw about 800 of these weirdlooking creatures on a farm near Marquard, in the IVinburg district. 'They consorted in herds of from four-

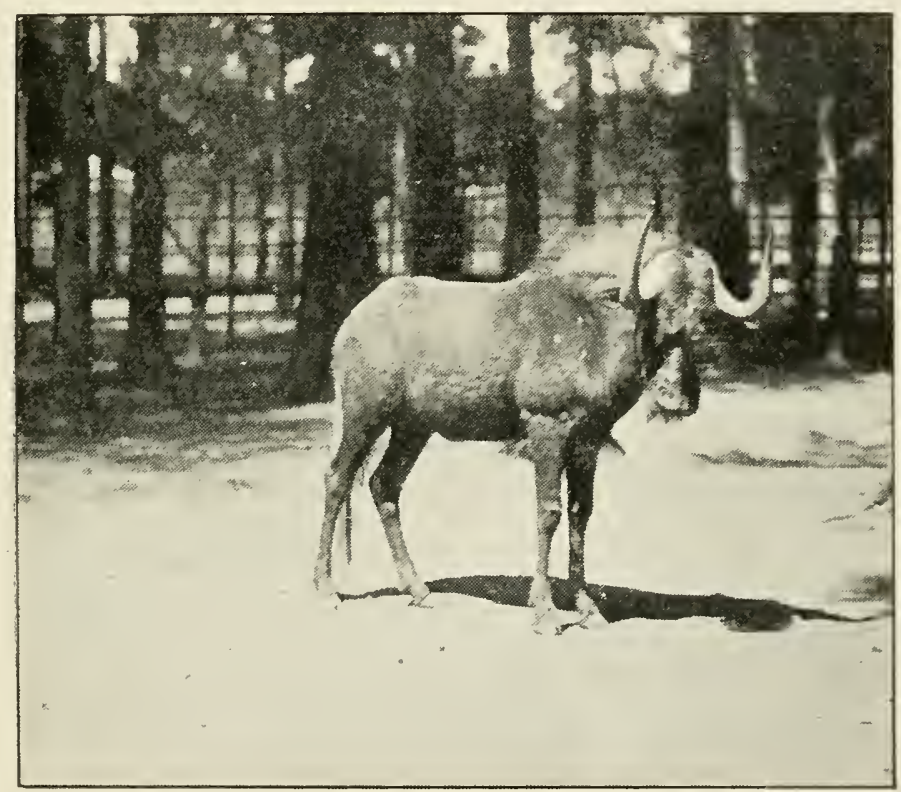

Frg. 91. - Wbite-tailed Gnu or Plack Wildebeest.

teen to sixty individuals. One small herd consisted of bulls (thirteen in number), from which I shot my speci.men. They galloped round our cart in circles, at a distance of about three hundred yards, and when fired at indulged in the extraordinary antics which have been commented upon by, amongst others, Mr. J.G. Millais, who illustrates these queer capers in his beautiful book, "A Breath from the Veld," in a lifelike manner. The female gives birth to a single young one in summer (from November to January). It breeds freely in captivity, and 


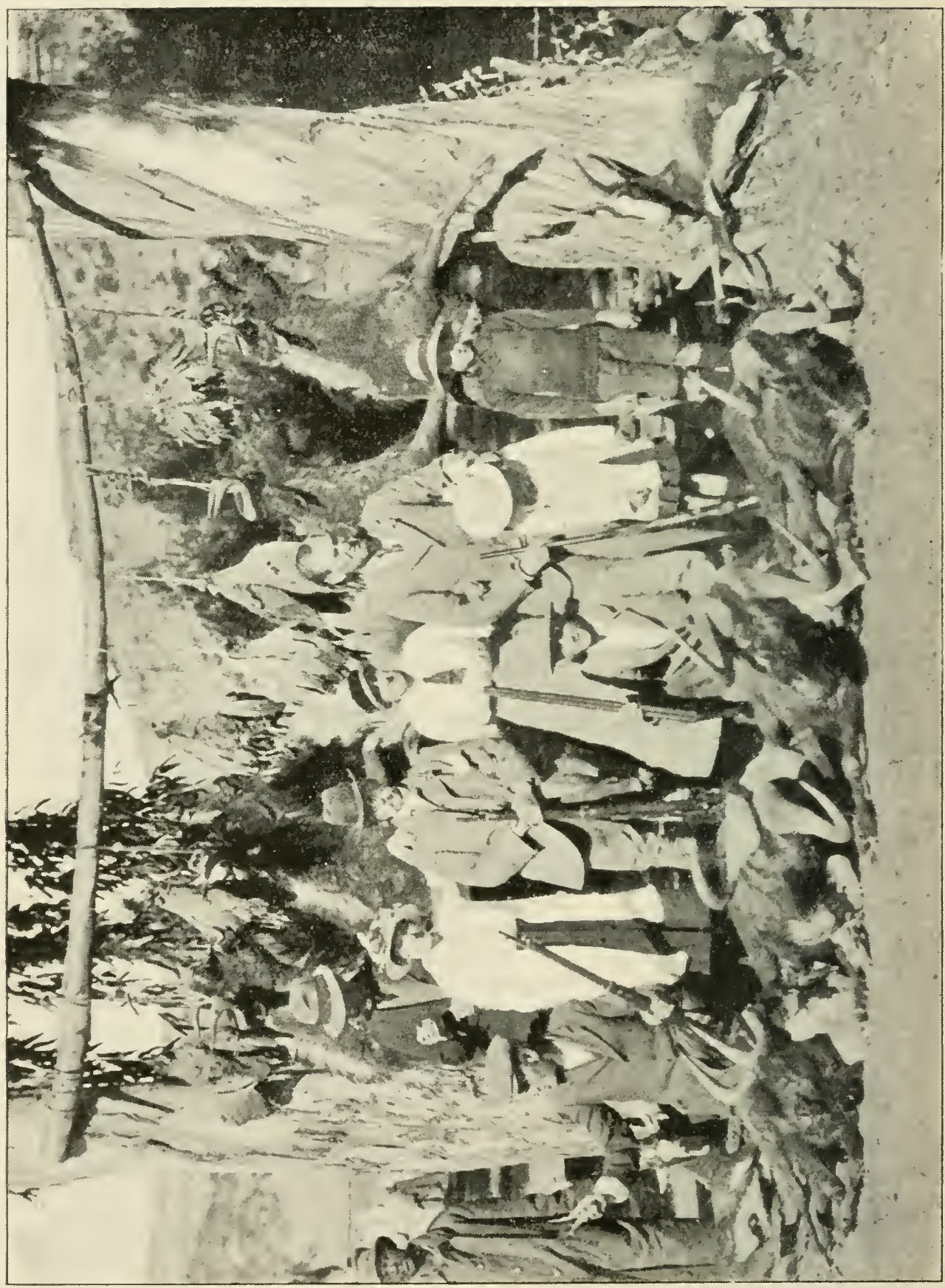

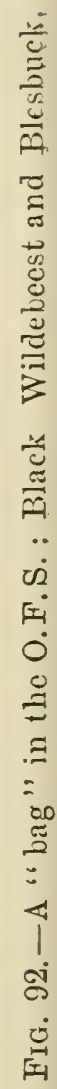


the Pretoria Zoo possesses several examples born in the Gardens. It is usually a treacherous and pugnacious animal in captivity, both to human beings and its own kind alike, and is ever ready with its curved horns. One particular bull in the National collection was so badtempered that he had to be kept isolated, and it was afterwards impossible to breed from him, owing to his having injured several cows. He had to be locked up in his stable before his paddock could be cleaned out.

\section{Genus CEPHALOPHUS.}

Small to medium-sized antelopes, of rather stout build. Glands are present, consisting of a row of pores on a naked line, running along the side of the face below the eye. A tuft of long hair on the crown between the horns. Tail short or medium. Lateral hoofs present. Mammse, four. Horns short and straight, and placed far back on the skull, with bases usually ringed or roughened. Female sometimes also horned in the first two species, nearly always in the third.

Cephalophus natalensis. Red or Natal Duiker.

Rooi Duiker or Rooi Bos-bokje.

Mlkumbi (Zulu); MIzumbi (Swazi).

This little animal, usually known to hunters by its Swazi name of "mzumbi," differs markedly in coloration from the succeeding species, being of a pure rufous or chestnut-red colour. Under parts brownish yellow. Tip of tail white. The tuft of hair on the forebead is longr and partially black. Height at shoulder 16 inches to 19 inches. Weight 26 to $30 \mathrm{lb}$. Horns short, and almost hidden by the tuft of hair, the bases stout and the 
tips streaked. Length about 2 to 3 inches. Record in the Transvaal Museum (Sir A. Bailey), $3 \frac{7}{8}$ inches.

The Red Duiker extends from Natal, through Swaziland, Eastern Transvaal and Southern Portuguese East Africa. From Mozambique northwards to.Zanzibar, it is replaced by the closely allied Cephalophus robertsi of Rothschild. The Red Duiker differs in habits from its greyer cousin in being essentially a denizen of the forest, being fond of thickly-wooded and well-watered kloofs. Its food is much the same as that of the Common Daiker. A single young one is usually born at a time. It is rather difficult to keep alive in captivity, notwithstanding statements to the contrary, although the examples possessed by us may have had rough handling in capture. It is also possible that the climate of Pretoria does not agree with them. The Zoo has had specimens from Natal, Barberton and Delagoa Bay.

Cephalophus monticola. Blue Duiter. Blaauwboktic. Ipietic (Zulu).

This diminutive antelope is also known by its Zulu name of Pietie (Pete'). It is about the size of a "Kolhaas" or Larger African Hare, and is a dark slatey colour or "smokey grey brown" with a black stripe on the nose, and the insides of the legs and belly whitish. The hoofs are pointed and narrow and the tail is fluffy, and black in the centre, bordered with white, and white below. Height at the shoulder 12 to 14 inches. Length of horns $1 \frac{1}{2}$ to 2 inches. Record $2 \frac{1}{2}$ inches. Both sexes are horned.

It is an inhabitant of the bush country of the Coastal belt, from George, eastwards through Cape Colony and Natal, to Zululand. In Albany Division it is very common in the thickly wooded kloofs, where the pattering 
of its tiny feet among the dead leaves may often be heard when one is lying in wait for game or birds. It usually goes about in pairs, feeding upon tender shoots, fruits, \&c. It has a shrill whistle-like bark, which it emits when alarmed, and while walking along has a

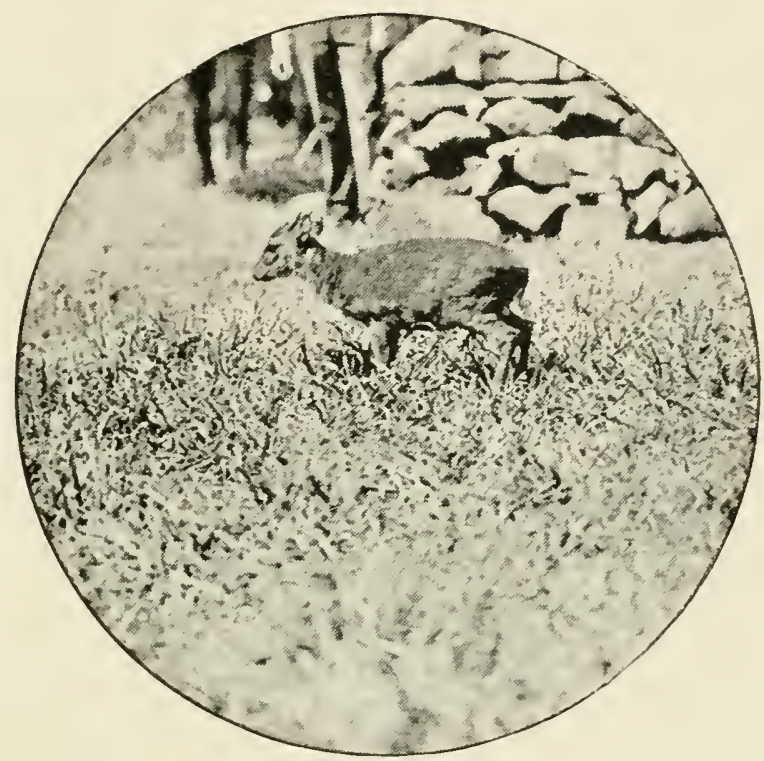

FIG. 93.-Blue Duiker.

funny little habit of wagging its tail every now and then. It is not an easy buck to keep alive in captivity, and should not be fed upon any hard foods such as mealies or oats. It thrives best upon green forage, leaves, lettuce and carrots, bran and bread.

Cephalophus grimmia. Common Duiker. Duiker Bok. MIpunzi (Zulu and Swazi); Xosa (Matabele); Iputi (Basuto and Bechuana).

This is a medium sized antelope of a rather delicate build. Colour a grizzled fawn-grey, or yellowish-drab, the individual hairs being ringed with black and yellow at the tips. The colour varies considerably in shade 
from drab-grey to dark-grey, the latter being more often found in the Cape. A black stripe on the middle of the face; forehead and a tuft of hair between the horns, rufous brown. Chin, belly and the inside of the legs white, frout of legs and all round at the fetlock, black.

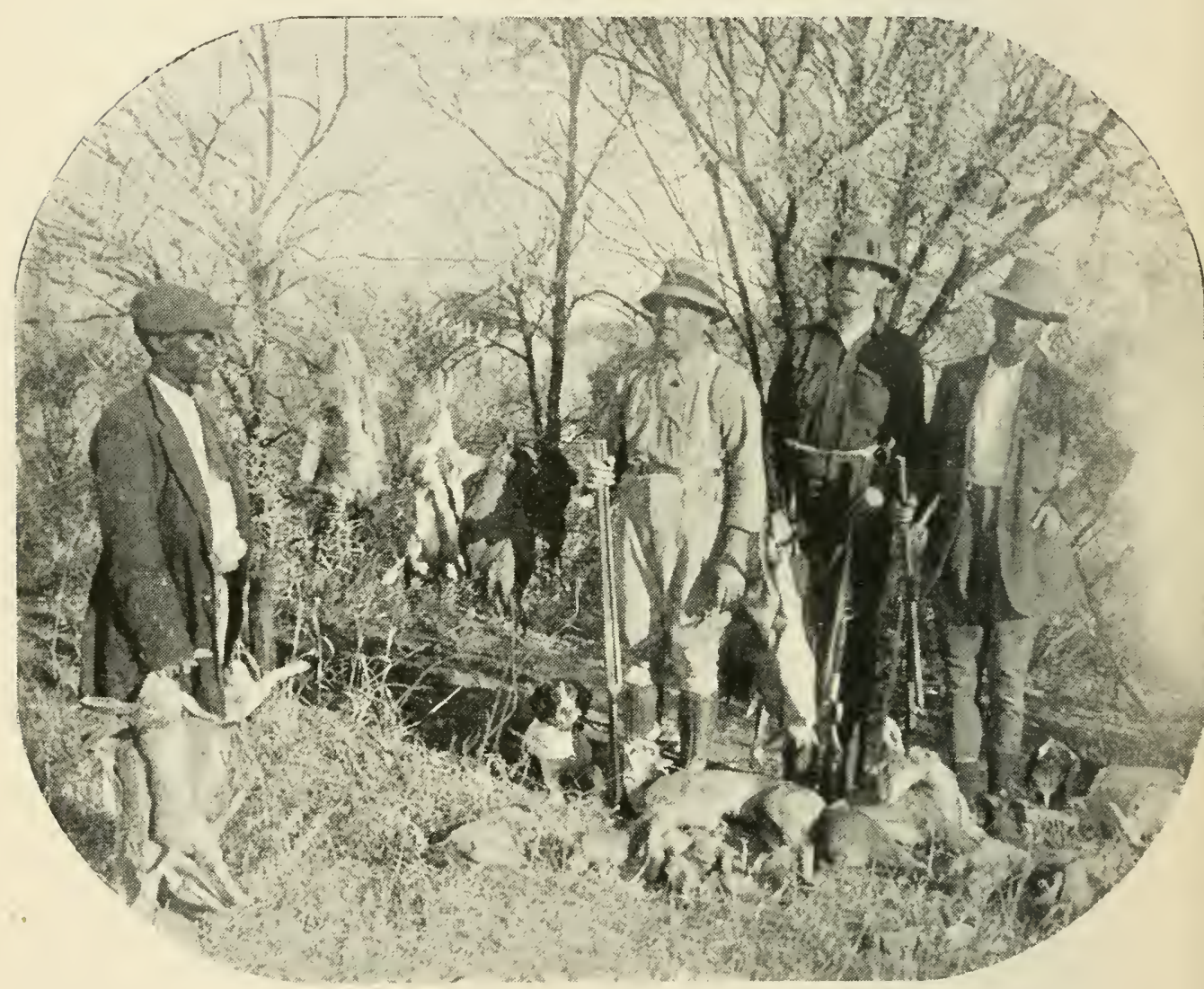

FIG. 91.-A Pretoria Bush veld "bag": Duiker on the right.

The female is also sometimes horned; if so the horns are thin, pointed and often deformed; the author possesses a pair measuring $2 \frac{1}{2}$ inches.

The horns of the male are straight, sometimes divergent to a more or less degree, ringed and roughened at the base, smooth toward the tips and varying from 3 to 6 inches in length. Pecord $6 \frac{3}{4}$ inches. Height at 
shoulder about 23 inches. Weight about $40 \mathrm{lb}$. T'he female is as a rule larger than the male and has larger buttocks.

Duikers vary in size according to the locality, those of the sandy parts of the 'Transvaal Bushveld being the largest, while those of the Kafue Flats (Northerm Rhodesia) are small.

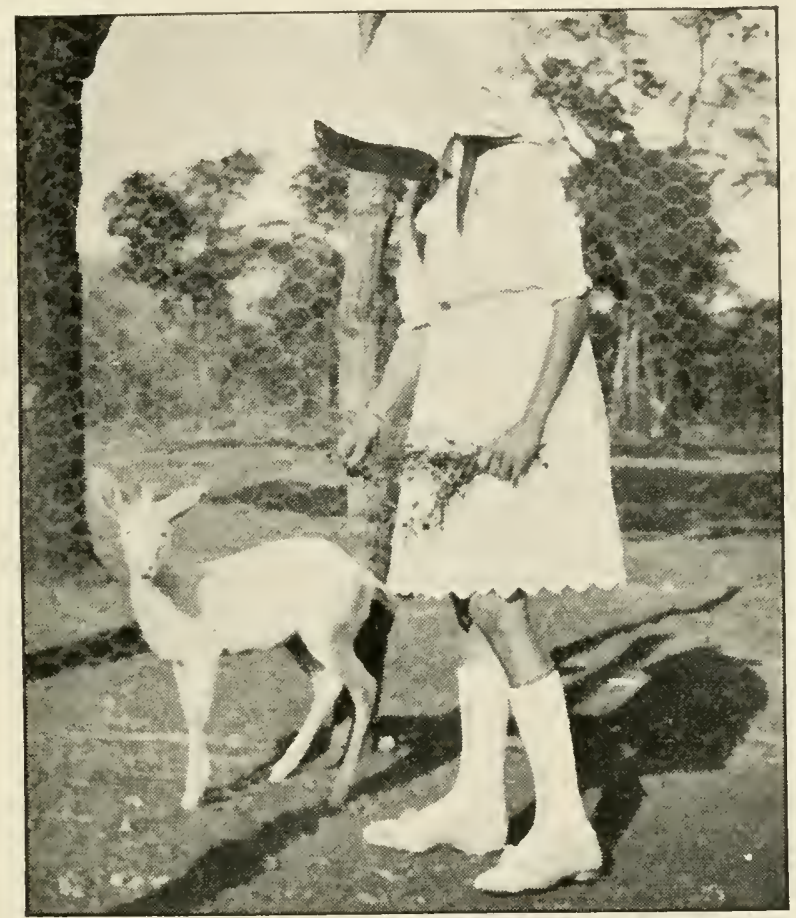

FIG. 95.--Albino Duiker.

There is a partial Albino in the Transvaal Musem from the Pretoria district. It is not pure white, but of a light strawberry roan, owing to a number of the hairs being normal in coloration. The lower part of the legs are normal. A photograph of a pure Albino from Southern Rhodesia is also appended.

The Duiker seems to be distributed over the whole of South Africa, and inhabits open bush country, or the scrub on low kopjes. It is fast, and has a habit of 
"diving" into cover, hence its Dutch vernacular name. One, sometimes two, kids are horn in the spring. It feeds in the early mornings and evenings, lying asleep in the middle of the day. It is fond of tender shoots of shrubs, fruit, and the young grass on the "burns." Although independent of water, the Duiker will drink when water is procurable. It is usually found singly or in pairs and takes some straight shooting to bag with a shot-gun, and the proportion of unrecovered wounded animals is somewhat heavy. A fine example wounded by the author was tracked by him and a friend for over two hours, and had finally to be abandoned owing to the absence of a well-trained dog. The Boer farmers shoot this animal with the rifle, stalking it in the early morning, when the animal is feeding.

The rams are sometimes pugnacious in captivity; one particular individual in the Zoo gored a native in the leg and injured him seriously. The Duiker breeds fairly well in captivity.

\section{Genus OREOTRAGUS.}

Hair of a thick bristly nature, quite unlike that of any other South African Antelope. Hoofs perpendicular, blunt and cylindrical, long and well adapted for resting on precarious positions on the cliffs. Horns only present in the male. Antorbital glands large and situated in front of the eye. Rhinarium large.

Oreotragus oreotragus. Klipspringer. Klipbol.

Ikumi (Basuto); Ligoka (Zulu and Swazi); Ingululu (Makalaka).

Colour brown, thickly speckled with yellow, the thick and coarse hair being whitish at the base, brown in the middle and yellow at the tip, the general effect being 
almost golden in bright light. Body below whitish. Tail extremely short (barely 1 inch). Horns straight, ringed at the base and from 3 to $5 \frac{3}{4}$ inches in length. One in Sir Abe Bailey's collection, now in the Transvaal Museum, measures $5 \frac{7}{16}$ inches. A pair in the possession of $\mathrm{Mr}$. J. IV. Chaney, Zandrivierspoort, near Nylstroom, measure

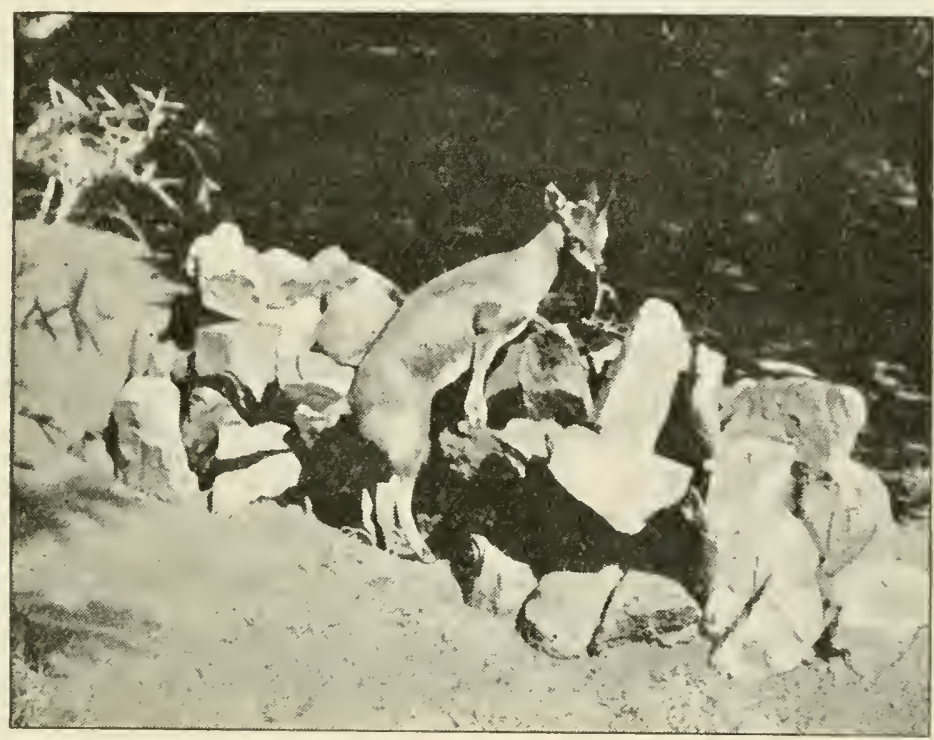

Fig. 96.-Klipspringer Ram.

$7 \frac{3}{4}$ inches. Height from 13 to 2 feet; weight $35 \mathrm{lb}$. It is found in nearly all the rocky mountains of South Africa, where it resides in small parties of from three to ten individuals.

It is, however, becoming scarce in most localities and has been rigorously protected in most of the districts in the Transvaal of late years. It is very agile, resembling the Alpine Chamois in its powers of leaping and balancing itself on rocky pimuacles, where hardly a foothold seems possible. It feeds on the bushes and grass of the mountain slopes, and descends at uight to drink. Its breeding habits are unlinown. TTe have 
had only a few of these curious little antelope in captivity, the first one of which did not live long, but there are at present two males in the collection, one presented by Lieut.-Col. van Telden and the other purchased from Natal.

\section{Genus OUREBIA.}

Small antelopes with the normal hair of the African Antelope. Hoofs pointed. False or accessory hoofs small. A bare spot below the ear. The chief distinguishing characteristic of this genus is the tuft of long hair on the knee. The male only carries horns, which are ridged at the base, straight and slightly curved forwards. Only a single member of the genus comes within the geographical range of South Africa.

Ourebia ourebi. Oribi Antelope. Oribi.

Inla (Swazi and Zulu); Puduludukameni (Basuto).

Colour a yellowish red or ochreous brown. Below and the insides of the upper part of the legs whitish. A broad white eyebrow. Lips white and the rhinarium large. Ears fairly narrow, with a glandular bare spot below the base on either side; tail with a conspicuous black tip, which characteristic is alone sufficient to distinguish it from the Steenbol. Horns slender, slightly curved forwards and from 3 to 6 inches in length. Record $7 \frac{3}{16}$ inches. Height about 20 inches. One weighed by Dr. Schoch turned the scale at $36 \mathrm{lb}$.

This little antelope appears to be confined to the eastern portion of the sub-continent, ranging from Uitenhage C.P. to Mashonaland, extending, however, as far north in Rhodesia as the region of the Barotse River valley. It is usually found in open grass country, not far 


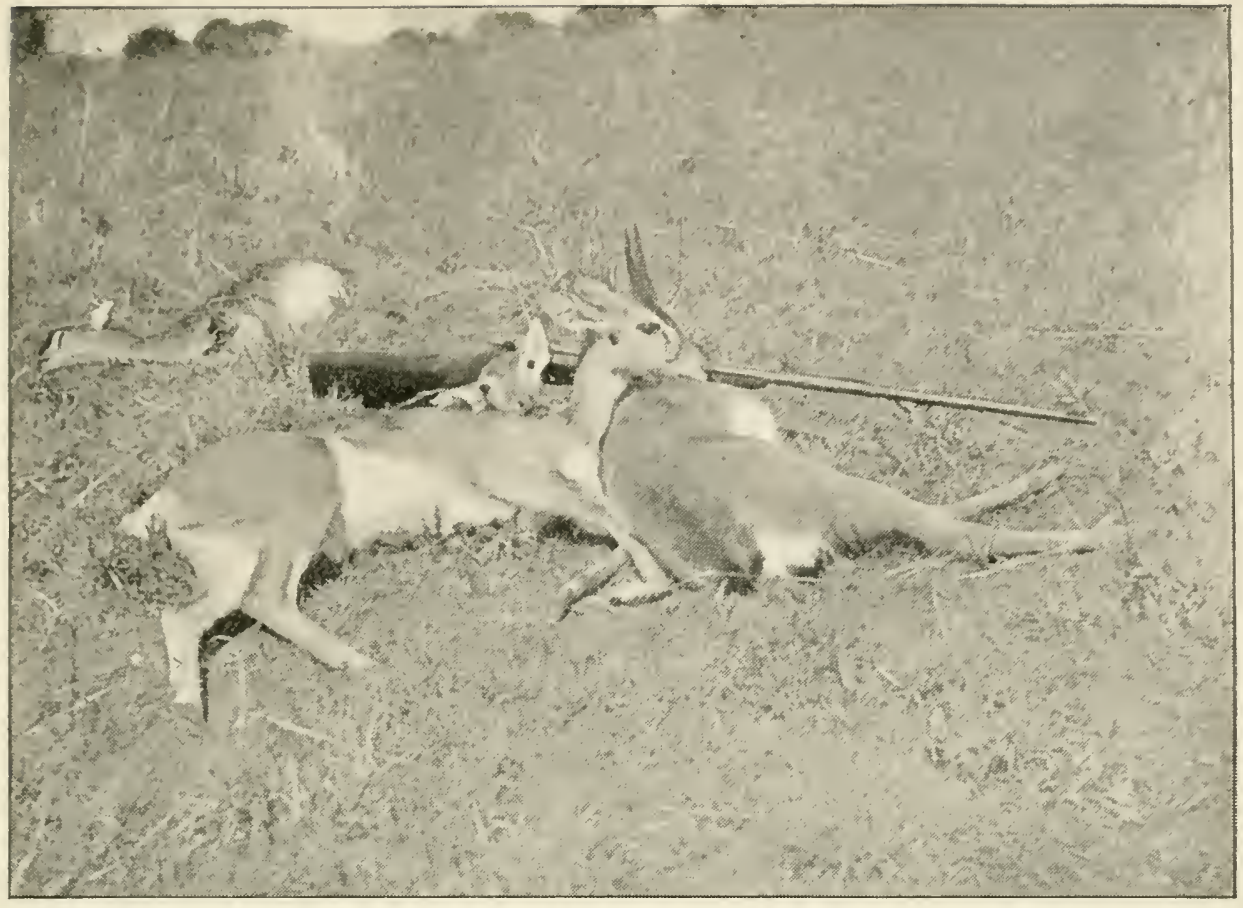

FIG. 97.-A fine pair of Oribis.

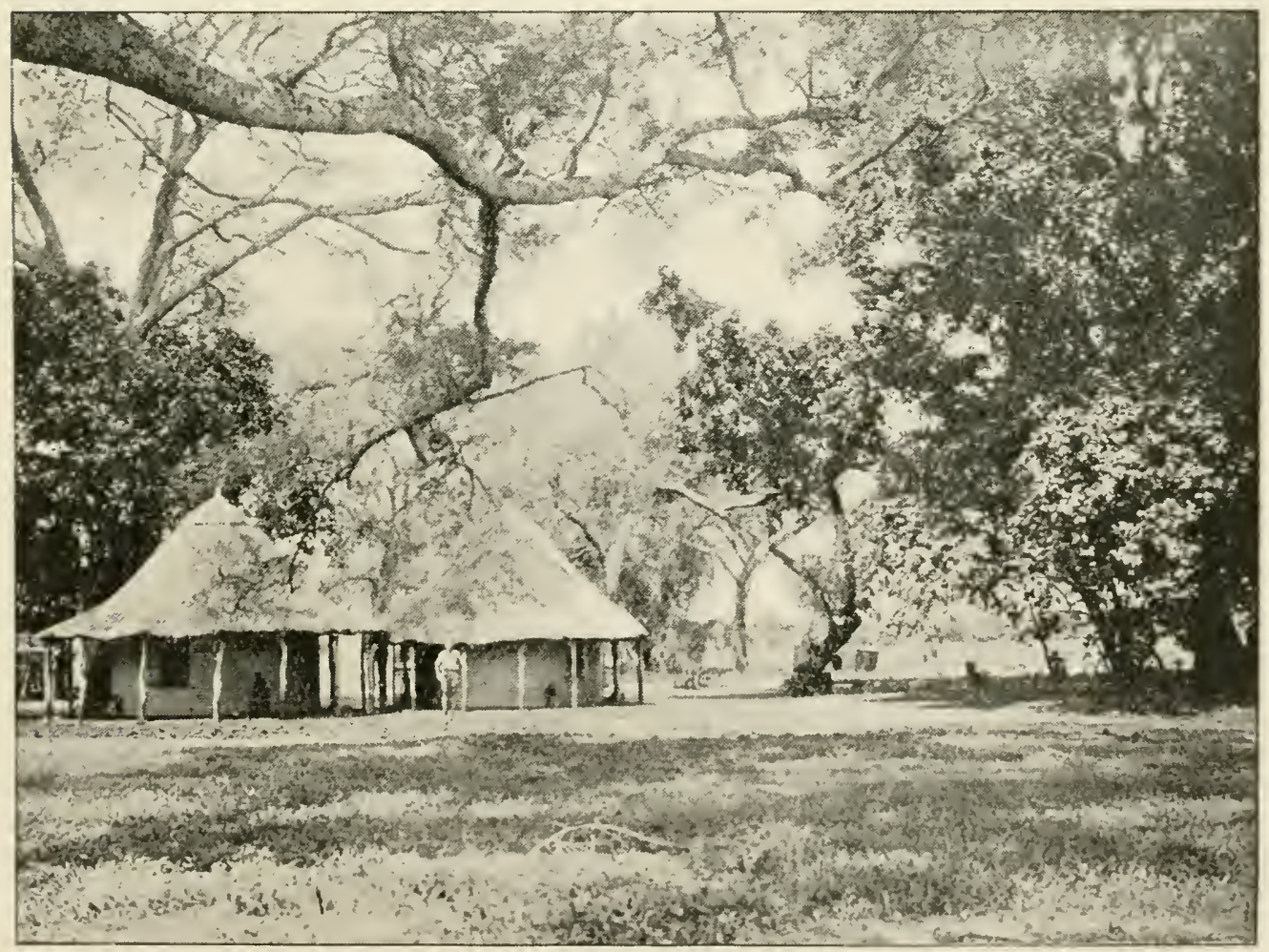

FIG. 9S.- "Fufwa," near Monze, N. Rhodesia - the home of the Oribi. 
from water, where it goes about in pairs-sometimes in small troops of four or five. It is said to be a very fast runner. The Zoo has had examples from the Standerton, Middleburg and Pretoria districts; and from the Kafue Flats, Northern Rhodesia, where Dr. A. A. Schoch found them very common in August, 1919, and the author in November of the same year.

\section{Genus PEDIOTRAGUS.}

Resembling the preceding, but being without the naked glandular spot below the ear, and withont the knee-tufts. Males only with horns, which are short and vertical.

Pediotragus tragulus. Grysbuct. (irijsbok. Isitiupi (Basuto).

Colour reddish-brown, with white hairs interspersed amongst the reddish, giving a grizzled appearance to the skin. Below, eyebrow, chin and throat whitish; fur long and coarse. Ears large and rounded; accessory hoofs present, but very small. This animal is heavier and more sturdily built than either of the two succeeding species. Horns resembling those of the Steenbok, but somewhat shorter and stouter; length 4 inches, record $4 \frac{7}{8}$ inches. Height at shoulder 20 to 22 inches. Length of head and body about $2:$ feet. The Grysbuck ranges from Cape Town in the IVest, along the coastal belt to the Eastern Cape Colony. To the north of the Limpopu and in the Zambesi valley it is common according to Selous, but this must be an error and no doubt refers to Sharpe's Steenbok (Pediotragus sharpei). The National Zoological Gardens have had examples from Stellenboseh, C.P. It inhabits open bush country where it prefers to lie hidden all day, coming out to feed during the night or 
early morning. It is fond of the young tendrils or shoots of the vine, and is in consequence not loved by the wine farmers.

Pediotragus horstocki. Steenbuct. Steenbol. Iquini (Zulu); Impulupudi (Basuto); Unguena (Matabele); Ingaina (Swazi); Phuduhudu (Bechuana).

Colour a pale reddish-brown, varying in shade and intensity according to age and locality; below, including the buttocks, white, or nearly so. A black mark on the face from the naked skin of the nose, half-way towards the eye. A whitestripe over the eye. There is generally a I-shaped black mark on the forehead. The limbs are slender and there are no knee tufts, nor false hoofs. The true hoofs are narrow and pointed. The female is hornless. Horns hardly ridged at the base; from 3 to $5 !$ inches in length. Record $7 \frac{1}{2}$ inches. Length of head and body 34 to $3 \tilde{y}$ inches. Height 20 to 22 inches. Weight 20 to $28 \mathrm{lb}$.

This is a graceful little animal, and is the most widely distributed of the South African Antelopes. It is found in open bush country or on rocky ridges. At Brandfort, Orange Free State, we found it amongst the mimosa scrub on the flats near hills, and in the Johannesburg district on the open veld in the vicinity of the eucalyptus plantations, to which it betakes itself when alarmed or pursued. It shares with the Duiker in being the commonest of the African Antelope in districts where suitable cover exists, and is still fairly plentiful in parts of the Bushreld of the Pretoria, Rustenburg and Waterberg districts, wherever poaching and Kaffir dogs have given it a chance. It is usually found singly or in pairs, feeding during the early hours of the morning or towards and after sunset. It is easily killed by means of a 
shot-gun, and is delicious eating. One young one is usually produced at birth.

Pediotragus sharpei. Grizzled or Sharpe's Steenbuck.

Transvaal Grijsbolije or Schimmel.bokje.

This little animal was confused with the Cape Grijsbuck until some years ago, when specimens were collected and it was seen that it was different, being much smaller, lighter in build, and paler in colour. It is in size and build about on a par with the common Steenbuck, and like it, has no accessory hoofs. It is, however, much darker and redder in tone and has a copious sprinkling of white hairs. Horns very short, from $1 \frac{1}{4}$ to $2 \frac{1}{4}$ inches in length. It is fairly common in the more hilly and bushy regions of the Central and Eastern Transvaal. This variety, which Thomas has separated under a new sub-specific name, extends northwards through Southern Rhodesia, being replaced in Northern Rhodesia and Nyassaland, dc., by the typical species.

\section{Genus NESOTRAGUS.}

Rhinarium practically surrounding the nostrils. No false or accessory hoofs. No linee tufts. Males only horned.

Nesotragus livingstonianus. Livingstone's Antelope.

Livingstone Bolije.

Intilengana (Amatonga); Sithlengone (Swazi).

Colour rich red-brown; hairs tipped with paler, giving to the animal a slightly speckled appearance. Insides of the legs and the lower parts from a pure to a dirty white colour. Upper throat, chin, and a small eye-brow, white or whitish. Legs with a black band just above the hoofs. 
Horns thick, straight, and strongly ringed for about threequarters of their length; length $3 \frac{1}{2}$ to $4 \frac{1}{2}$ inches. Record 5 inches. Height at shoulder 12 to 14 inches. Length $2 \frac{1}{4}$ feet. 'The southern form was given a separate subspecific name by Oldfield 'I'homas (zuluensis) on account of its "grizzled fawn colour," and the little black on the fetlocks, but a specimen in the Transvaal Museum from Delagoa Bay fits this description fairly well, while examples in the Zoo from the same place are reddishbrown.

This pretty little Antelope ranges from Zululand to Nyasaland. It was very common in the neighbourhood of Delagoa Bay, but is getting scarcer every year, owing chiefly to native poachers. It inhabits the thick bush and scrubby undergrowth. It is very fast, and dodges well when pursued. It has a bark-like call, and a snortlike whistle. It does not thrive well in captivity, being like the Blue Duiker and the Steenbuck-of a shy retiring: nature, and seldom lives longer than a year, unless given a large paddock and more or less natural conditions of life.

\section{Genus MADOQUA.}

Small Antelopes with pointed, lengthened and swollen noses, well clothed with hair, only the skin of the nose being bare. Tail very short. A tuft of long hair on the crown. Horns straight and short and well ribbed at the bases. Accessory hoofs small.

Madoqua damarensis. Damara Dikitit. Damara Duergbolije.

Colour dark speckly grey, with the flanks, sides, neck, and shoulders of a plain pale rufous. Below and inside of legs, a ring round the eyes, and chin, white. Length of head and body about 2 feet. Height about 16 inches. Length of horns 3 inches. 
Little is known of the habits of this quaint looking little animal, as it inhabits barren dry and rocky hills, where it is not easily procured owing to its agility. Its range would appear to be from Omaruru in the South Western Protectorate to Benguela in Portuguese West Africa.

Sub-Family CERVICAPRIDE.

Rhinarium well developed. No antorbital glands, and the females without horns. Tail moderately long and bushy.

\section{Genus COBUS.}

Large-sized Antelopes with coarse hair, naked muzzles and moderately long tufted tails. False hoofs well developed. The males only are horned. The face glands are rudimentary or wanting altogether.

Cobus ellipsiprymnus. Waterbuch. Waterbok or Tring.gat. Li-Tumoga (Matabili); Matuti (Barotse); Tumoga (Bechuana); Piva (Swazi).

A rather stoutly built animal, of a grizzly grey-brown colour, almost a roan, the individual bairs, which are course and long, being paler at the bases, and darker at the tips. The chin, and the region round the nose is white. Forehead reddish, and the face browner than the body. A white streak under each eye. There is a white line on the throat and another one, broad and conspicuous, round the rump. The hair of the neck is long and reversed, forming a mane-like ruff. Horns long, ringed and curved backwards and outwards for about three quarters of their length, then upwards. Length $2 S$ to 36 inches. Record $366_{4}^{1}$ inches. Height at shoulder about 4 feet. Length $7_{4}^{\frac{1}{4}}$ feet. Tail 15! 
inches. A fine mounted male in the Transvaal Museum possesses horns 32 inches long. Weight 400 to $5.50 \mathrm{lb}$. The skin is thick, especially that of the neck. It is much prized for whips.

The Waterbuck ranges from the northern portion of South West Africa, and Lake Ngami to Rhodesia, and on the east from Zululand to Nyasaland and Somaliland. The example referred to in the Transvaal Museum was procured by Major Hamilton in the Eastern Transvaal, where this species is still fairly common, especially in the Game Reserves. Waterbucks do not stray far from water, consorting in herds of from five to fifteen individuals, and inhabiting broken country in the vicinity of rivers, where they hide in the reedbeds and thickets when wounded or hard pressed, or during the heat of the day. According to all hunters the flesh is unpalatable, being coarse and strongly flavoured. It feeds almost exclusively upon grass, young reeds and rushes. It is not an easy animal to kill, so the hunter should make pretty sure of his aim before pulling trigger. It is a good swimmer and is a fairly fast animal on flat country, and an active climber in the rocky localities, to which latter region old bulls are very partial.

Cobus leche. Lechwe Antelope. Lechwe-bok and Geel Waterbok.

Lechwic (Bechuana); Liegwhi (Makololo); Narja

(Mashukulumbwi).

This animal is smaller than the Waterbuck and is of a tawny rufous or yellow-brown colour; below white. Front portion of legs black. Tail long, tufted, and reaching to the hocks. A feature which will easily distinguish this Buck from its allies of the Cobus genus, is the nalied pastern, i.e., the space between the false 
and true hoofs. It has the hind quarter's higher than the fore, giving it rather an ungainly appearance. Horns curved outwards for the lower half, and the tips bent sharply forwards. They are ringed nearly to the tips. Length about 28 inches. Record length $34 \frac{7}{8}$ inches. Length of head and hody $(6$ feet; tail 10 inches. Height 38 to 40 inches. The male has a thick bull-like neck and a short podgy head.

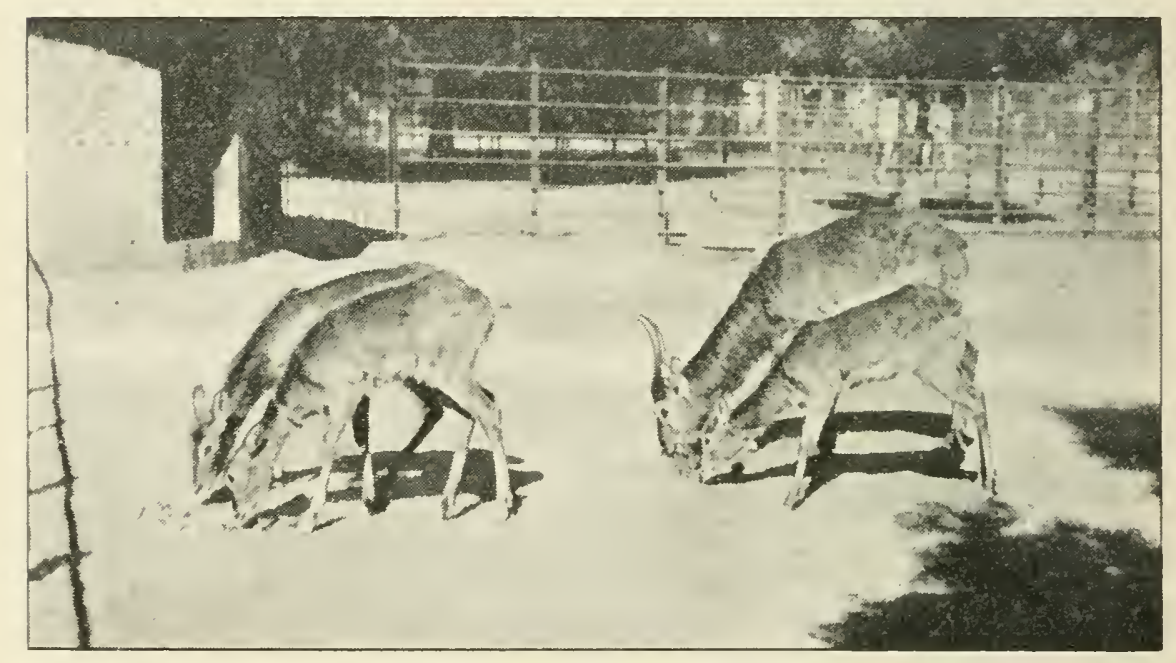

FIG. §9.-Lechwes feeding.

The Lechwe ranges from Lake Ngami northwards to Lake Mweru and is a water-loving Antelope, inhabiting those low-lying tracts of open grass country which are often flooded from the low-banked rivers. It is often found half immersed in the water, feeding upon reeds, rusbes and other water plants in the lagoons, reedbeds, ic. It swims well, and when hunted by the natives is driven into deep water and assegaied. The skin of the female Lechwe is the national dress of the Mashukulumbwi women. It consorts in herds of varying number, and Selous once counted fifty-two rams in one herd, with not:a single ewe amongst them. It breeds in October 
and November. It is fairly plentiful along the Kafue River in Northern Rhodesia, but it is now getting wary. It carries its head low, the nose almost touching the

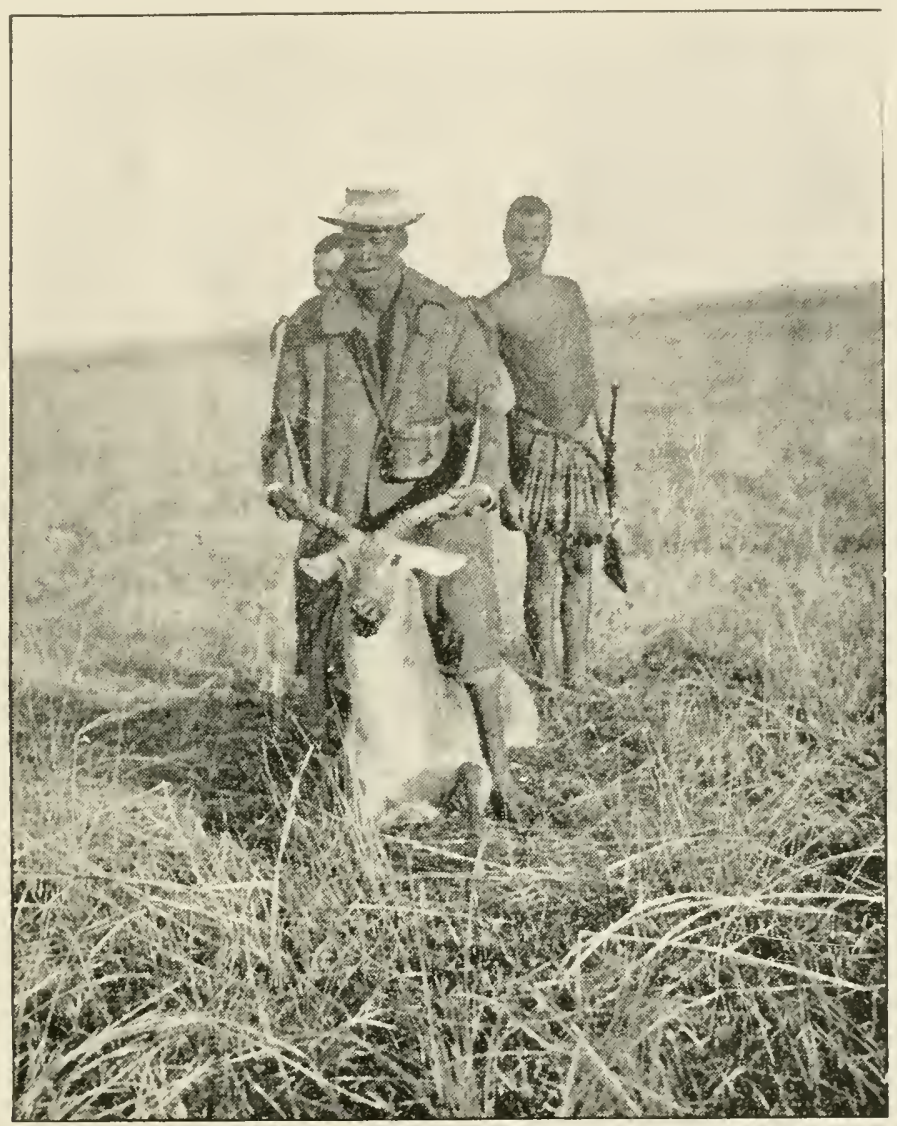

Fig. 100.-Lechwe Ram (Kafue Flats, N.R.).

ground, and proceeds in this manner both while walking and trotting, only lifting its head when stretched out in full gallop.

Cobus vardoni. Puku Antelope. Puku Bot:

IIuntinya (Barotse) Pulu (Ngami natives). Sitchisunu (Mashuliulumbwi).

Colour a reddish or brownish orange yellow, paler on the lower surface. Ears tipped with black, which immediately distinguishes it from the adult Lechwe. 


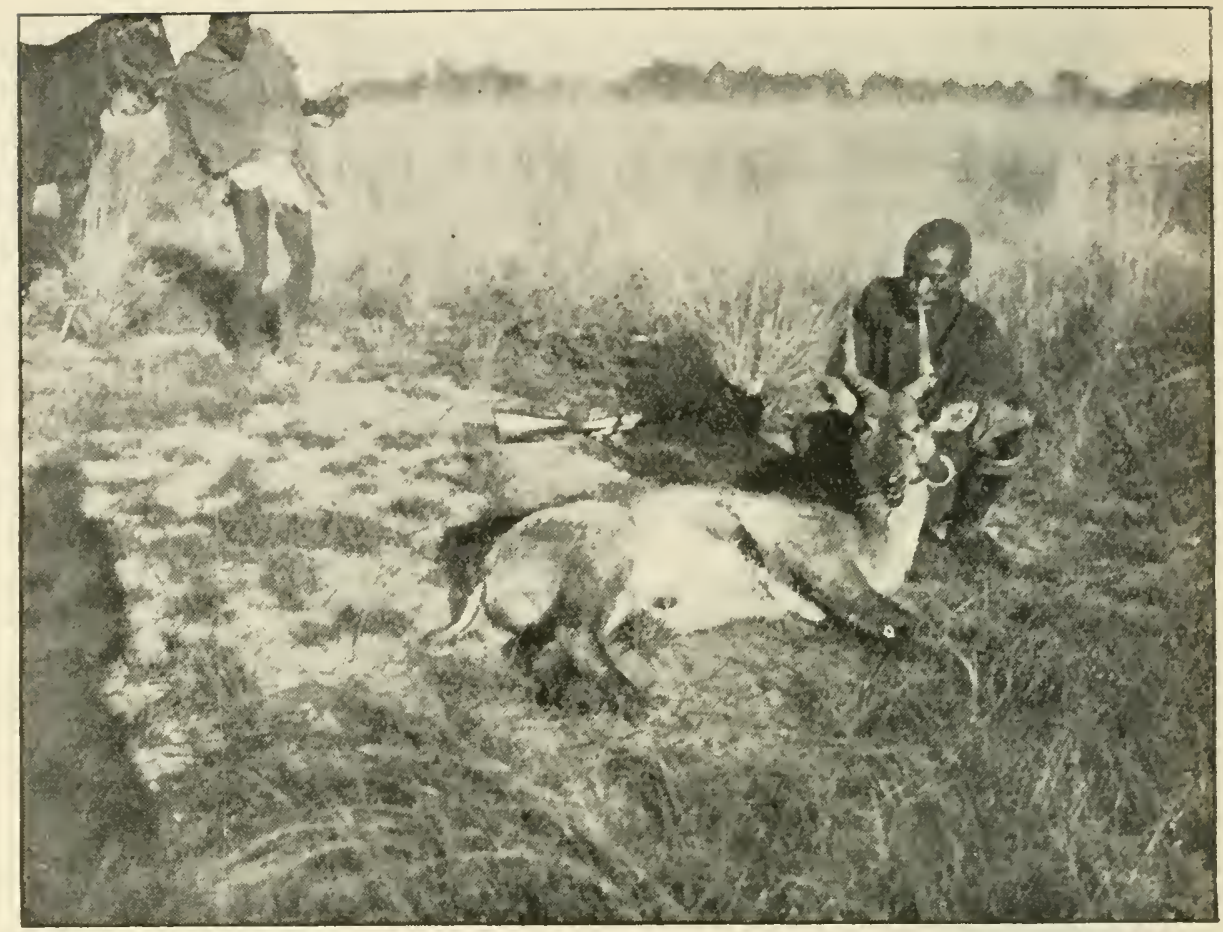

Fig. 101.-Puku Ram (Kafue, N.R.).

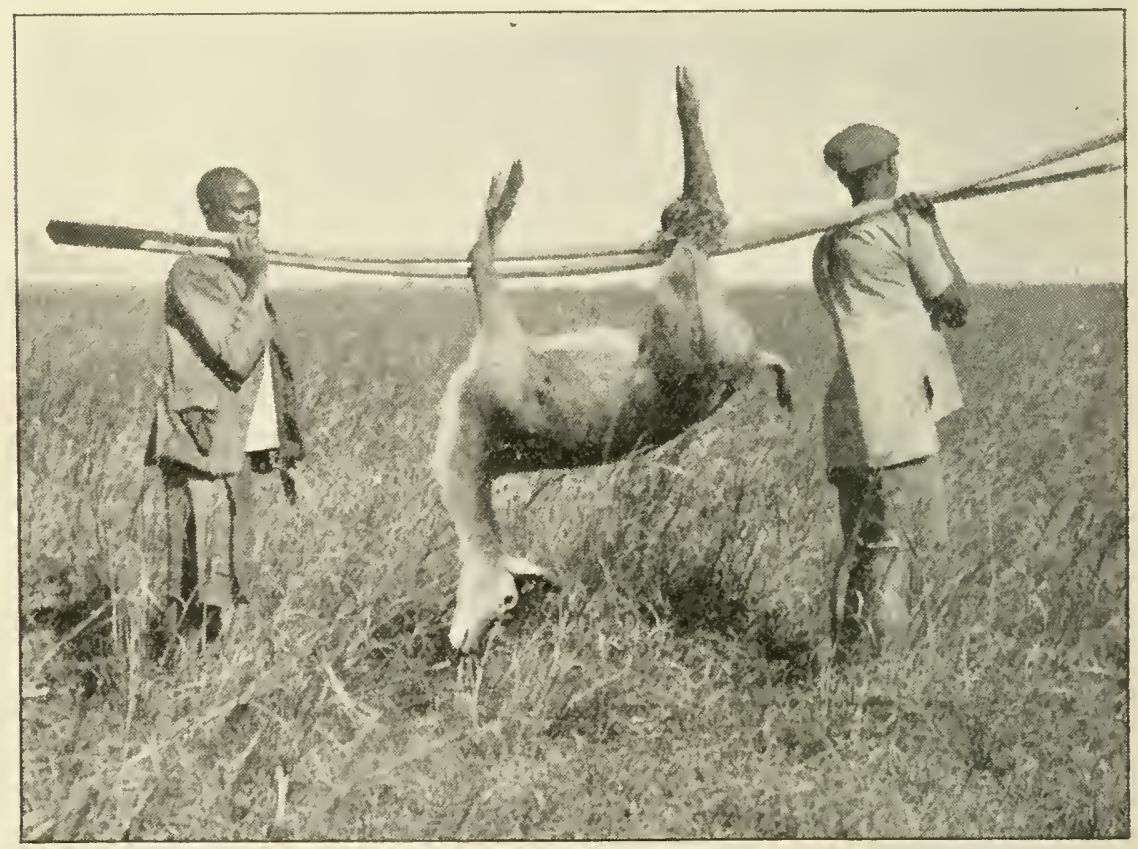

FIg. 102.-Bringing in a dead Fuka. 
Pastems hairy. 'Tail short. It is a more lightly built and more graceful animal than the Lechwe. Horns curved slightly forwards and outwards and the tips bent forwards. Length 15 to 20 inches; record $20:$ inches. Length of head and body $55_{4}^{3}$ feet; tail $7 ! \frac{1}{2}$ inches. Height about 3 feet. Weight about $200 \mathrm{lb}$.

'I'his Antelope, like the Lechwe, was discovered by Livingstone's party. The Puku ranges from the Zambesi Valley to Lake Miweru. It has a fairly wide distribution in the Zambesi and Chobi Valleys (Barotseland), being common on the Krafue River about a hundred miles from the railway line. It is not quite so aquatic in its habits as the Lechwe, but is seldom found more than 800 yards away from a river or lagoon. It lives in small herds of from four to a dozen individuals, old rams being found singly or a few consorting together. They are more like Waterbuck in habits, feeding on river banks, and lying under bushes or trees during the heat of the day.

Trouessart puts these two last species in a separate genus, Adenota of Gray.

\section{Genus REDUNCA.}

Resembling the preceding genus considerably. Tail short and very bushy. A glandular bare spot below the ears on the sides of the head. Horns only present in the males.

Redunca arundinum. Recdbuck. Ructbol. Nhlango (Swazi); Mzikic (Natabele and Zulu); Mutubo (Barotse). Imfele a nalia (Bechuana); Nalufwa (Mashukulumbri).

General coloration a tawny or pale reddish-brown, the hairs being yellow at the tip and dark at the base; of a paler colour below and on the sides of the face. A 
rounded swelling on the nose. Ear patch bare. Face glands small. Fore legs with a black stripe down the front and encircling the limb just above the hoof. 'Tail bushy and white beneath, which shows conspicuously as the tail bobs up and down when the animal is in flight. Horns black, curved backwards and upwards with the tips directed forwards, and ringed for about two-thirds

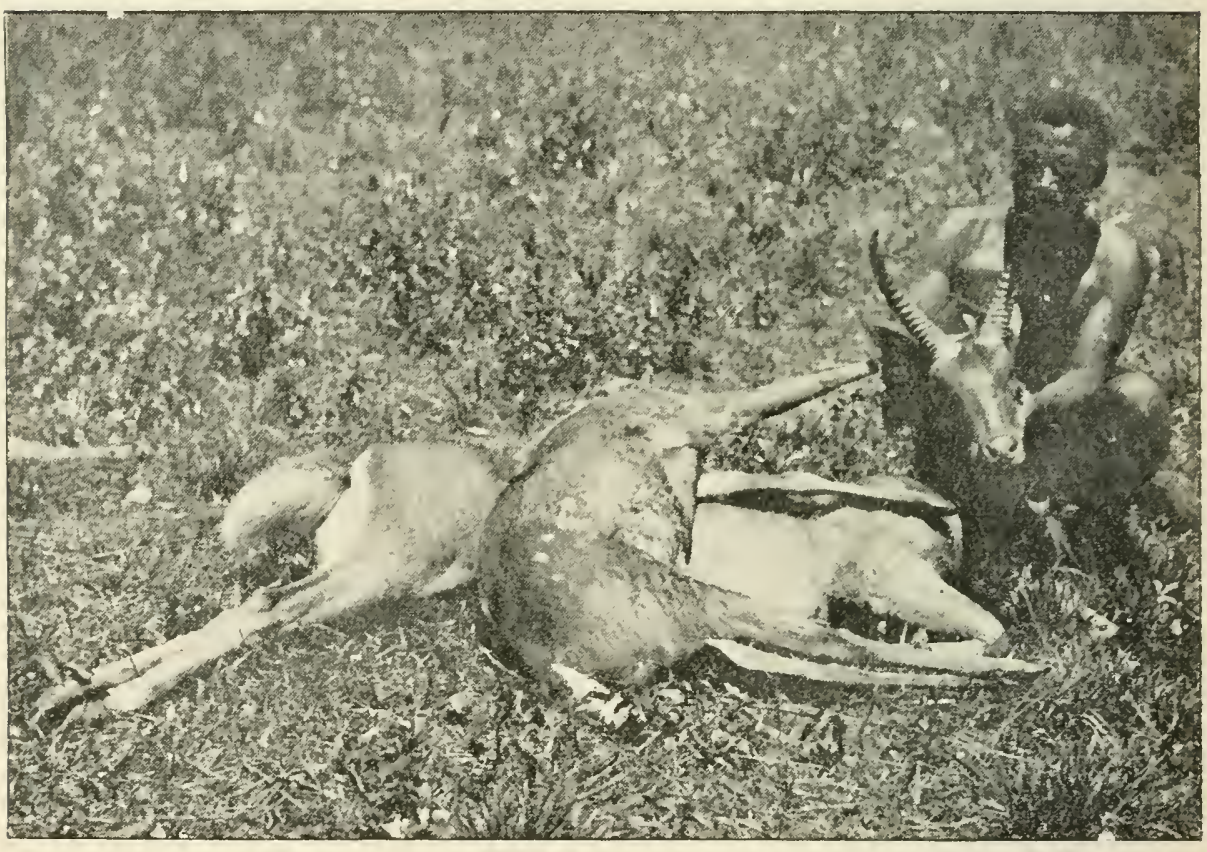

Fig. 103.-Dead Reedbuck (bottom) and Bushbuck (top).

of their length; there is a soft pad at the bases. Length about 12 to 16 inches; record 18 inches. Weight of rams about 160 to $180 \mathrm{lb}$. Height at shoulder $2_{4}^{3}$ to 3 feet. Length 4 to 4 ? feet.

The Reedbuck ranges from Eastern Cape Colony, where it is now very scarce, through Natal and Zululand to Rhodesia, reappearing on the West Coast.in South-West Africa. It is still fairly common in certain parts of the Northern and Eastern Transvaal, but owing to indis- 
criminate shooting is becoming scarcer, and will have to be wholly protected for a few years. It lives in valleys in the neighbourhood of water courses and vleis or on bushy ridges, consorting in pairs, or family parties of three to seven individuals. It feeds at early morning and evening or during the night, lying up in some thicket or patch of scrub during the heat of the day. It is a grass feeder and its flesh is of high quality. It emits a shrill whistle when alarmed or excited.

Redunca fulyorufula. Red Rhebuck. Rosi Bhebok. N'gla (Swazi); Infele (Bechuana).

Smaller than the Reedbuck, and of a greyish to brownish tint; below and insides of the limbs pure white. Head and upper neck pale reddish-brown or fulvous. Limbs generally darker than the body. Tail tufted and white beneath, which is conspicuous as the animal bounds upwards in its rocky home. Horns short, ringed for the lower half, with the terminal half curved forward; length on the curve, 5 to 7 inches; record, $9 \frac{1}{16}$ inches. Height at shoulder, 27 to 30 inches. Length, 4 feet.

The Red Rhebuck is found from the Central Cape Colony, through the Eastern Province, Natal, Orange Free State, Transval, Bechuanaland, and as far as the Zambesi River in Rhodesia. We found it quite common in parts of the Orange Free State, where it inhabits the slopes and kloofs of rocky kopjes clothed with scattered scrub, in small parties of from two to six individuals. The male has a peculiar sharp, snorting whistle. On the Rheboksberg, near Marquard, Orange Free State, where they are preserved by the farmers, $T$ had the pleasure of counting over twenty on one day during Nay, 191S, one small herd of three and a fine solitary ram jumping out quite close 
to me and cantering leisurely away. It is wonderful to see the ease and grace with which this antelope bounds up the steep sides of a rocky hill, the muscular development of the hips and shoulders being immense. Young animals are excellent eating, although the old ones are somewhat coarse. This animal is easily lilled, being amongst the softest of the Antelope.

\section{Genus PELEA.}

Fur woolly and of a peculiar texture. Horns straight. Otherwise much like the foregoing genus.

Pelea capreolus. Grey Rhebuck. Taal Pihebol.

Shiatla (Basuto); Peelie (Bechuana); Ilieza (Swazi).

Colour greyish brown, almost pure grey in young examples; head and limbs of a darker tint. Fur rabbit-

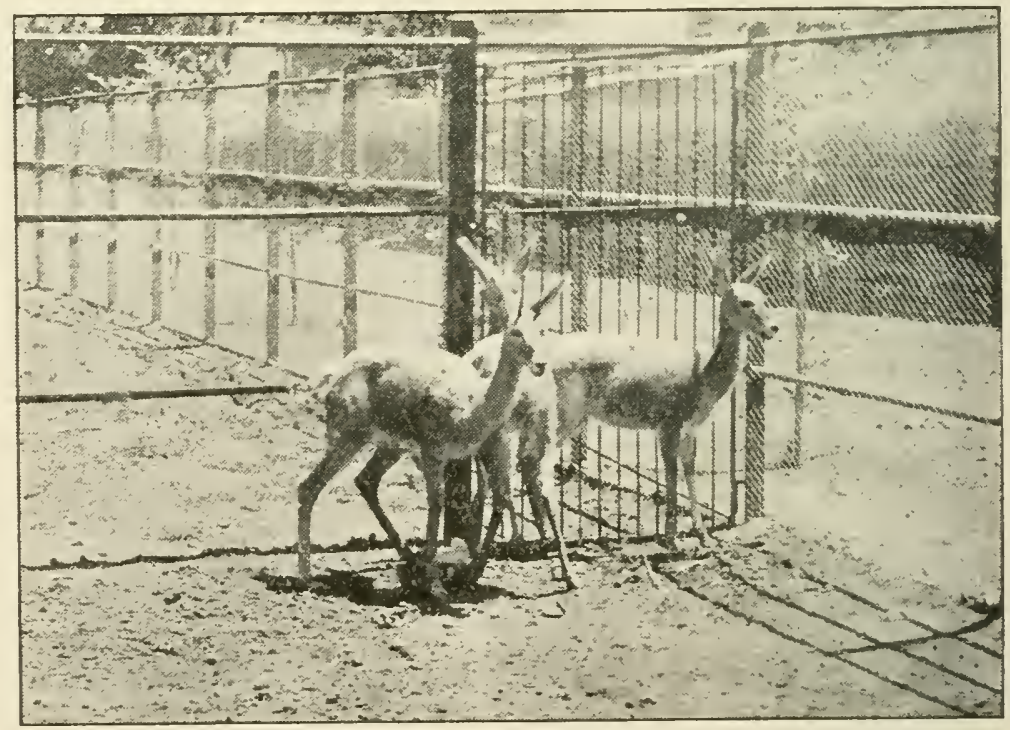

Fig. 104.-.-Vaal Rbebuck.

like or woolly, thick and soft; ears very long, pointed and narrow; neck long and slender; tail moderately long and bushy; horns straight, pointed and ringed for about half their length; length, 7 to 9 inches; record, $11 \frac{1}{2}$ inches. 


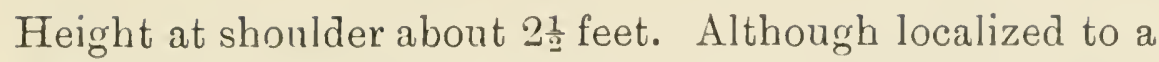
great extent, this animal is found on nearly all the mountain ranges of South Africa south of the Zambesi River. We found it not uncommon at several points of the Drakensberg Range. It inhabits mountains and hills, where it is generally found near the top, in parties of six to a dozen individuals. Its agility amongst the rocks is well known, and, although its gallop is rather stilted and of the rocking-horse type, it can cover the ground rapidly enough in its mountain home, where it bounds upwards with ease and grace. Its flesh is not of high quality. One or two young ones are produced at a birth. A female in the Zoo gave birth to a single young one. The National Zoological Gardens have obtained on several occasions examples from Basutoland, through the kind agency of Mr. J. P. Murray, Sub-Commissioner of Mafeteng.

\section{Genus AEPCEROS.}

Tail long and slender. No false hoofs. Tufts of hair on the lower portion of the hind legs. Female hornless.

Epyceros melampus. Impala Antelope. Rooibok.

Pala (Basuto and Bechuana); Impala (Swazi and Zulu).

This graceful Antelope is called the Rooibok by the Boers, on account of its general reddish-chestuut or bay colour; below it is white, as is also the chin and throat. There is a dark brown stripe on the buttocks on either side of the tail, and another down the latter portion of the back, nearly to the tip of the tail; this rather curious marking looks like the broad arrow on the dress of convicts when viewed from behind. There are black tufts on the hind fetlocks, whence its German name of "schwarzfersen antilope," and its Latin name of melampus (black-footed) 


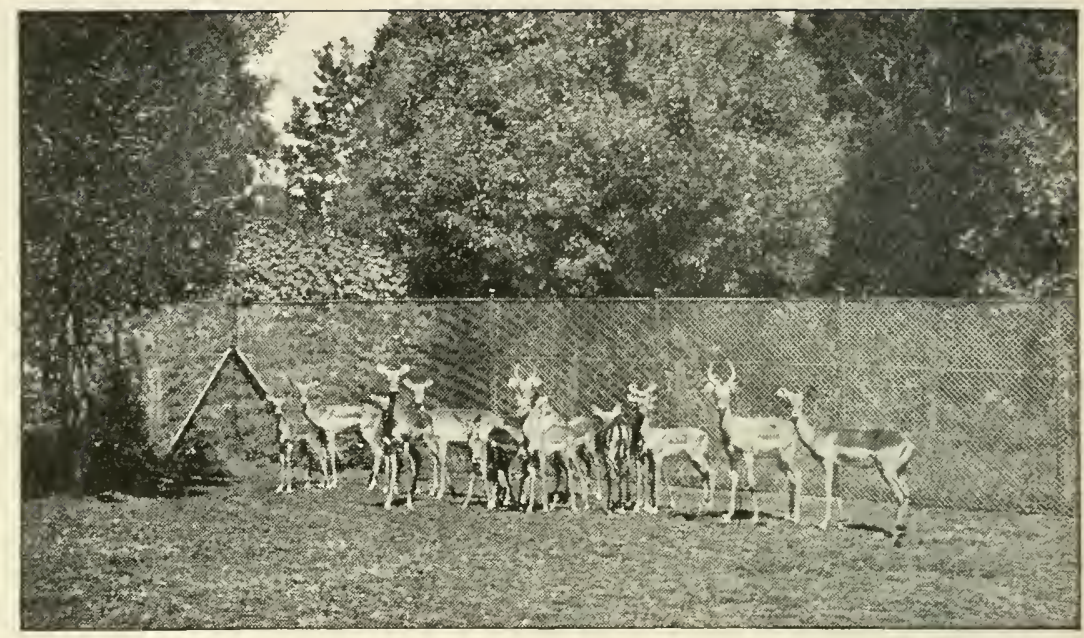

FIG. 105.-Impalas in the National Zoo.ogical Gardens.

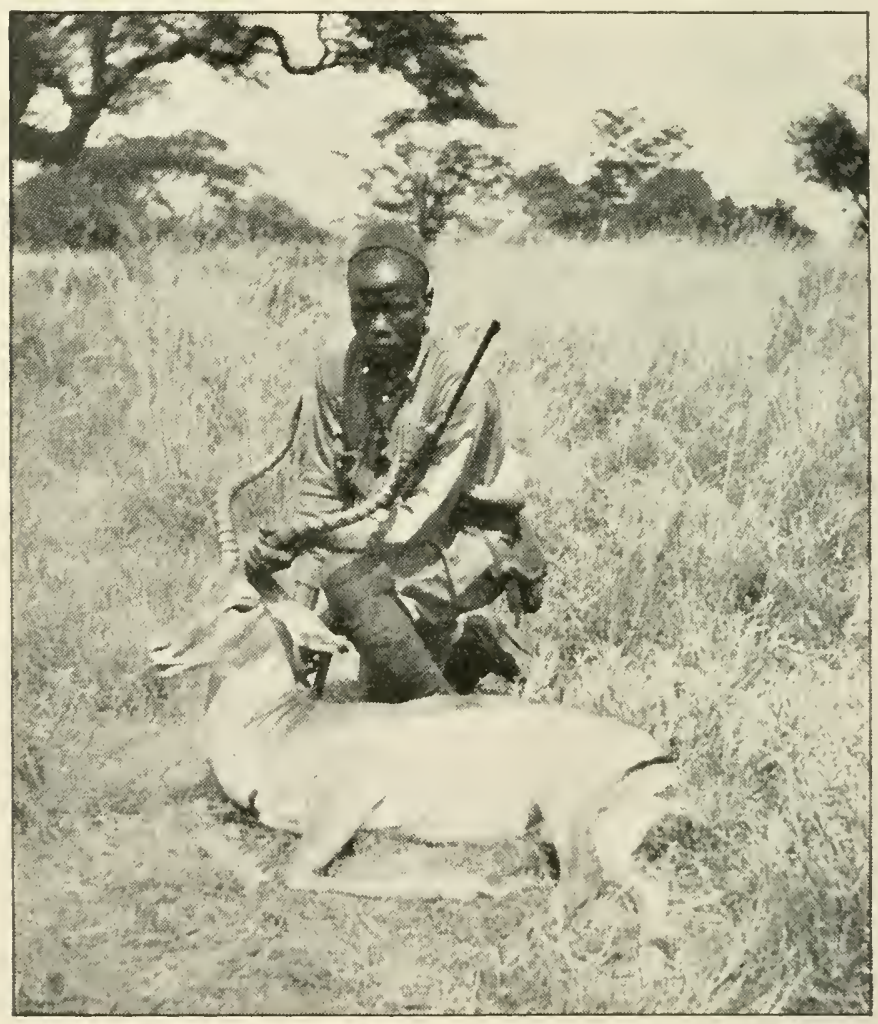

Fig. 106.-Dead Impala Ram. 
Horns lyrate, bent upwards, outwards and forwards, then inwards, and forwards towards the tip ; length, 22 to 30 inches (record, 31 inches). Height at shoulder, $2 \frac{1}{2}$ to 3 feet; length, $4 \frac{1}{2}$ feet; weight, about $130 \mathrm{lb}$.

The Impala ranges from Zululand through the Eastern Transvaal to Rhodesia and Portuguese East Africa. It prefer's the vicinity of well-wooded streams, consorting in herds of from half a dozen animals up to several hundred. It will on occasion stray far from water.

They leap wonderfully well, as Sir Percy Fitzpatrick points out in his typical South African book, "Jock of the Busbveld." A ram in the National Zoological Gardens cleared a fence of 8 feet, and two ewes two fences of $6 \frac{1}{2}$ feet in quick succession. We have had numbers from the Sabie Reserve, captured mostly when full grown. They breed quite well in captivity, and soon get tame. One young one at birth seems to be the general rule; the young are born during the months of October to January. The Impala feeds mostly on grass, and during the daytime.

\section{Genus ANTIDORCAS.}

Antelopes of medium size and with false hoofs present. The rhinarium is small and both sexes are horned.

There is a peculiar patch of long hair on the hinder portion of the back which can be erected at the will of the animal, and which opens like a fan.

\section{Antidorcas euchore. Springbuck. Springbol.}

$$
\text { I'sipi (Bechuana). }
$$

This animal is so well known as to need little description. Its characteristics amongst Antelopes is the peculiar crest or fan of long white hairs along the back 
contained in a fold or narrow pouch of skin; this can be erected at the will of the animal. It is an ally of the Gazelles, and is of an isabelline or pale reddish colour above, and white below, the two colours being separated by a broad band of bright reddish-chestnut. There is another band or stripe of chestnut on the face,

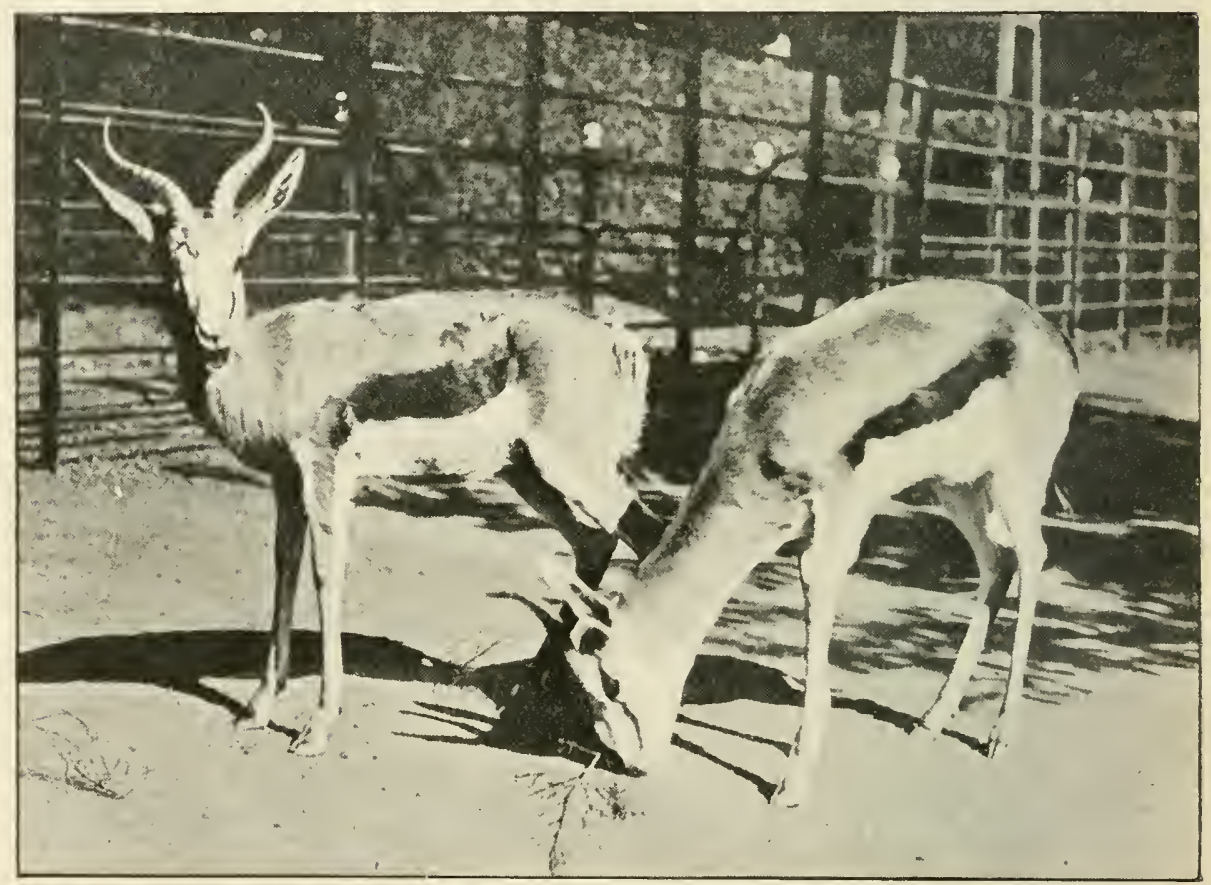

FIG. 107.-A pair of Springbuck.

and the rump, lilie the face, is white. Height at the shoulder 27 to 30 inches. Weight of rams 60 to $80 \mathrm{lb}$; ewes 40 to $50 \mathrm{lb}$. Both sexes are horned, although the female's are smaller, shorter and straighter, and only ringed at the base. Length 12 to $16 \frac{3}{4}$ inches. Record 19 inches (malformed).

In days gone by the Springbuck roamed over the veld in countless thousands, but is now only found in the Cape, South West Africa, Bechuanaland, Orange Free State, and some parts of the Transval (notably the 
Springbok Flats, where they have been protected for a term of years). The huge immigrations, about which we read so much in the tales of the old African travellers

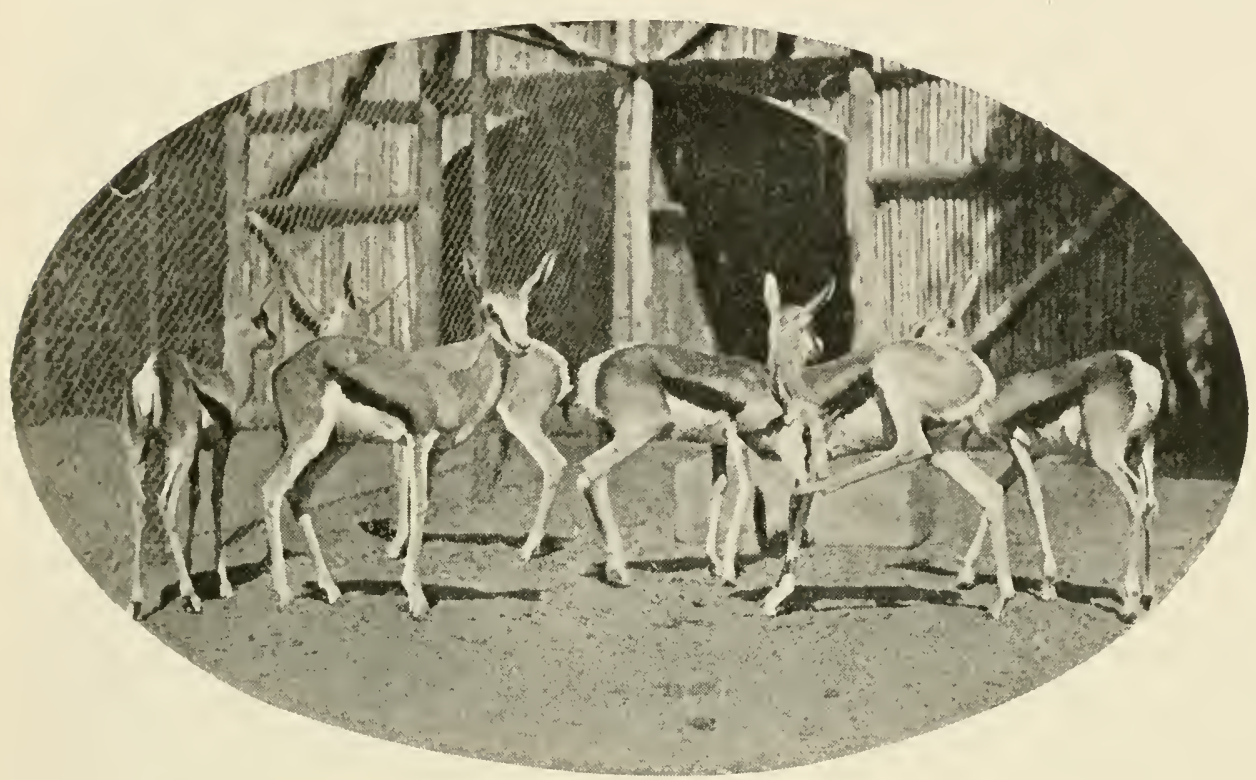

Fig. 108.-Young Springbuck.

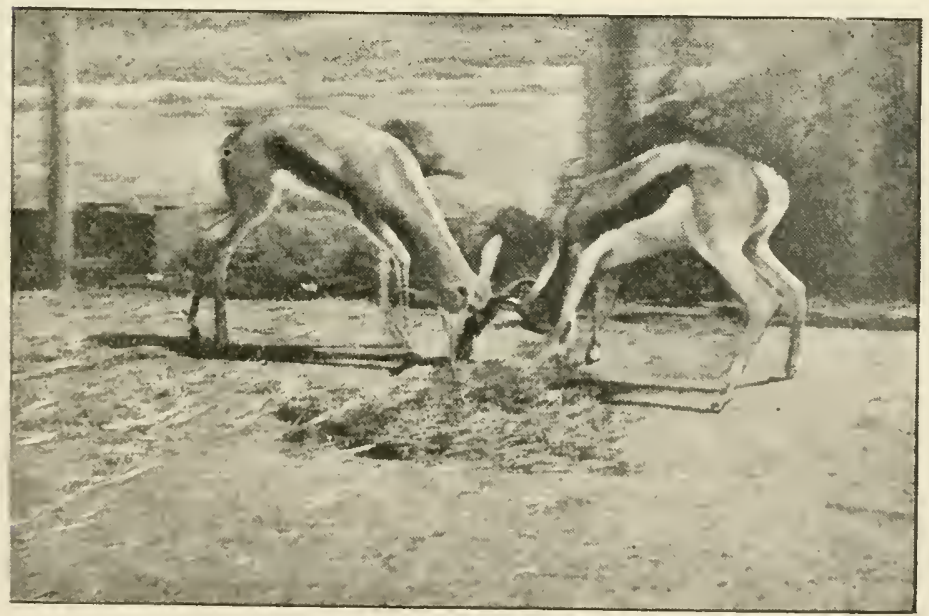

FIG. 109.-Springbuck Rams sparring.

(Gordon Cumming, Baldwin, (fc.), belong to the days of the past. The last big "trek" took place in 1896, although it is believed that there are still fairly large 


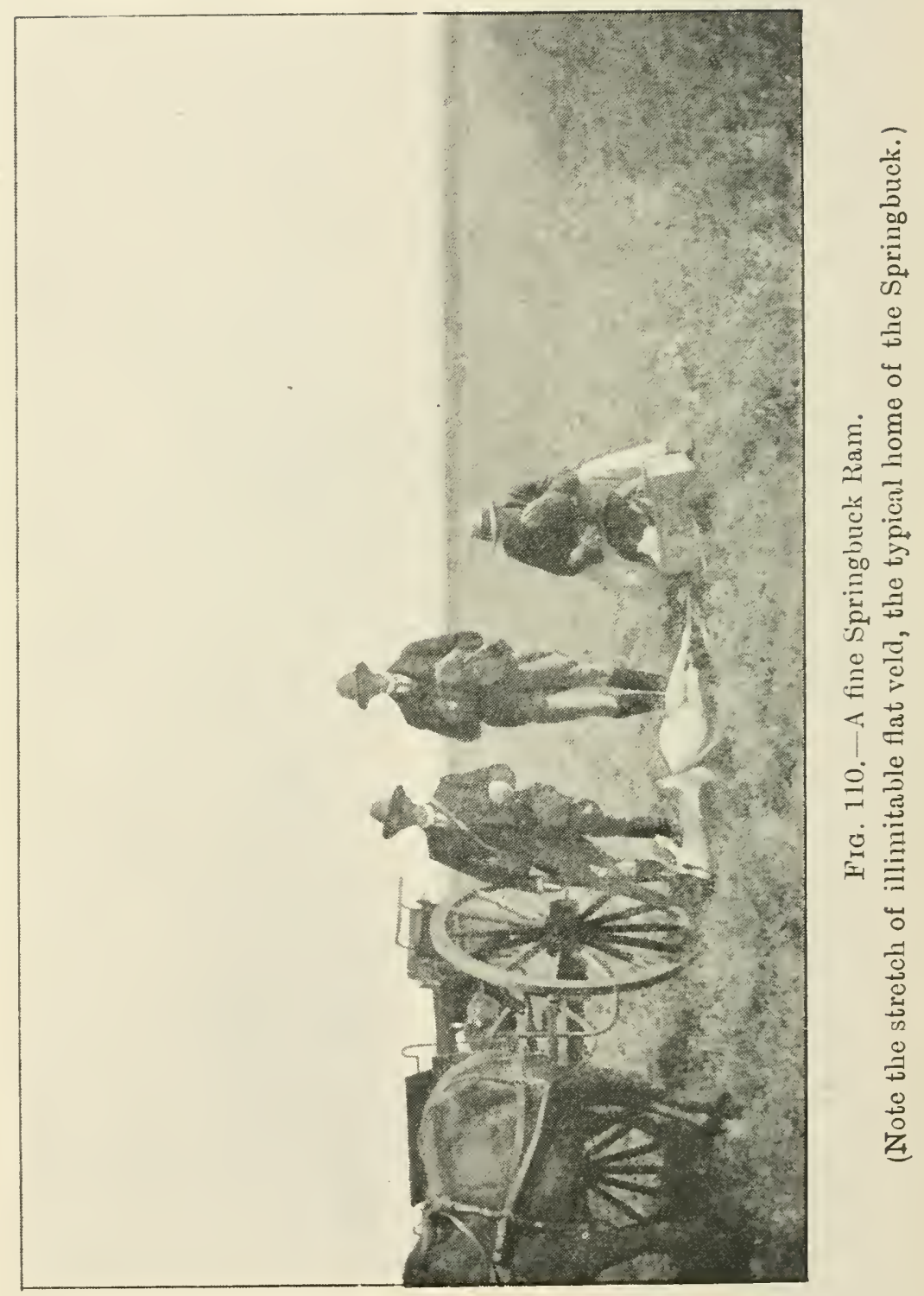


herds of "trek-bokken," as the Boers termed these migratory herds, in the Kalahari and North Western Cape Colony. In the Orange Free State, there are still many farms with large herds of Springbuck running on them, and the farmers are now learning the value of the venison as a lucrative article of trade, and their buck as a splendid source of income (through the medium of sportsmen and the market). It is often shot on the run at anything from 200 to 600 yards, although chances of a standing shot at 300 or 400 yards should be awaited. It consorts in herds of varying number, old rams, young males, females and lambs of all ages being found together. When disturbed they make off in a long line, and to me a more beautiful sight than this cannot be found on the veld. When pressed, or often when crossing a road, they commence bounding into the air and the ease and grace of their movements is unequalled.

As a rule one young one is born at a time, the early summer months of October and November being the proper breeding season, although young ones may be found in any month, even as late as June or July. 'This fact I have often noted when out shooting with the late Mr. H. P. Basson, of Brandfort, a wellknown Orange Free State shot and sportsman. More than one young one was captured by us during the shooting season, which only opens in March and closes in August. Springbuck venison is by many preferred to the flesh of any other South African Antelope and is fine eating.

\section{Genus HIPPOTRAGUS.}

Antelopes of fairly large size; tail long and tufted; mammæ four in number. Horns long, curved backwards and well ringed. The females are also horned, but carry lighter and more slender horns. One member 
of the genus, the true Blaauwbok (H. leucophous) is now extinct.

Hippotragus equinus. Roan Antelope. Bastard Eland. Kwalata (Bechuana); Irvalata tseu (Barotsi); 'Mtagaisi (Zulu); Taliaasi (Swazi).

Colour a grizzled pale or fawn brown, rather like what is sometimes lnown as a roan chestnut (almost a straw-

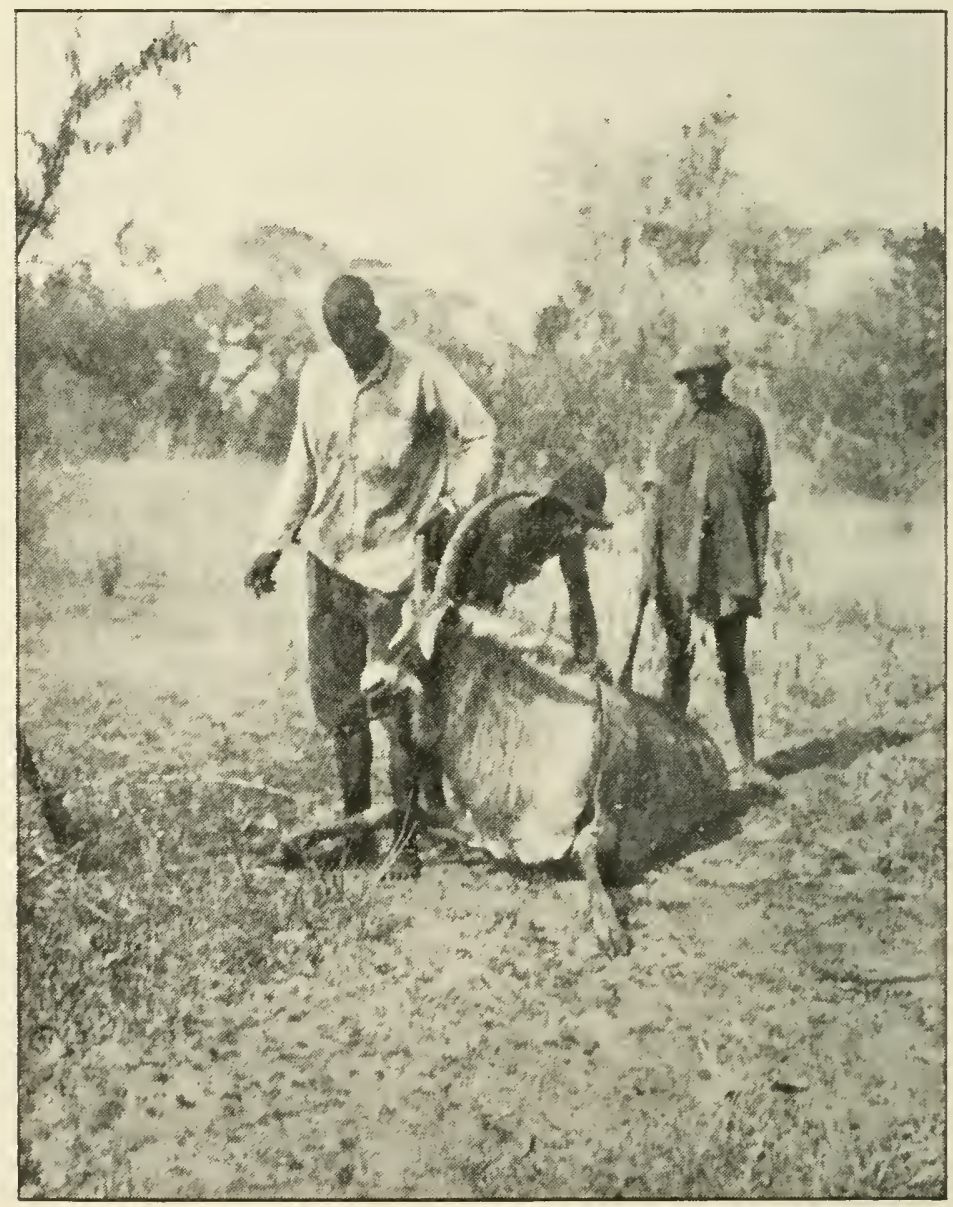

Fig. 111.-Dead Roan Antelope.

berry roan; in horses. Head dark brown; nose, lips, chin, a patch in front of and one behind the eye, white ear's long, and tufted with long black hair. A fairly 
well developed mane extends to the middle of the back. Tail tufted with long black hair. Horns fairly short for the size of the head and not so heavily curved as in the succeeding species, and rounder than those of the Sable. Length of male about 30 to 36 inches; female 24 to 29 inches. Records $40 \frac{1}{4}$ (male) 291 (female). Height at the shoulder from $4 \frac{1}{4}$ to $4 \frac{3}{4}$ feet. Length of head and body about 8 feet. It is a larger animal than the Sable. Weight about $600 \mathrm{lb}$.

It is now rare south of Rhodesia, though still found in Bechuanaland and the Eastern Transvaal, in the SouthWest Protectorate and Mashonaland. It inhabits open or hilly country clothed with scattered bush, consorting usually in small parties of from six to a dozen individuals. It will take to thick bush on occasion; it is a grass feeder, and drinks regularly. The young ones resemble those of the Sable, and are usually born in January and February. It is a bad runner, but a spirited animal when wounded, charging without fear. One example lived in the National Zoo for fourteen years, and was not young when received.

Hippotragus niger. Sable Antelope. Zwart Witpens.

Native names: Potoquani (Southern Bechuana); Kualata tchumu (Ngami, Bechuanas); Kualata inchu (Bamangwato and Makololo); Kualata nitso (Barotsi).

Colour, very dark brown, some of the bulls almost black. There is a conspicuous white stripe on either side of the face; chin and lower portion of jaw also white. It has a mane on the neck similar to that of the Roan. The rump, belly and insides of the hind legs above the hocks are white. The horns are longer, laterally compressed, and more curved than those of the Roan. Average 
length, 3 feet to 4 feet. Record, 60 inches. Height at shoulder, 4 feet to $4 \frac{1}{2}$ feet; length, $7 \frac{1}{4}$ feet.

This beautiful and graceful looking Antelope is now only found in the Northern and Eastern Transvaal, Portugnese South-East 'T'erritory and Rhodesia, so far as

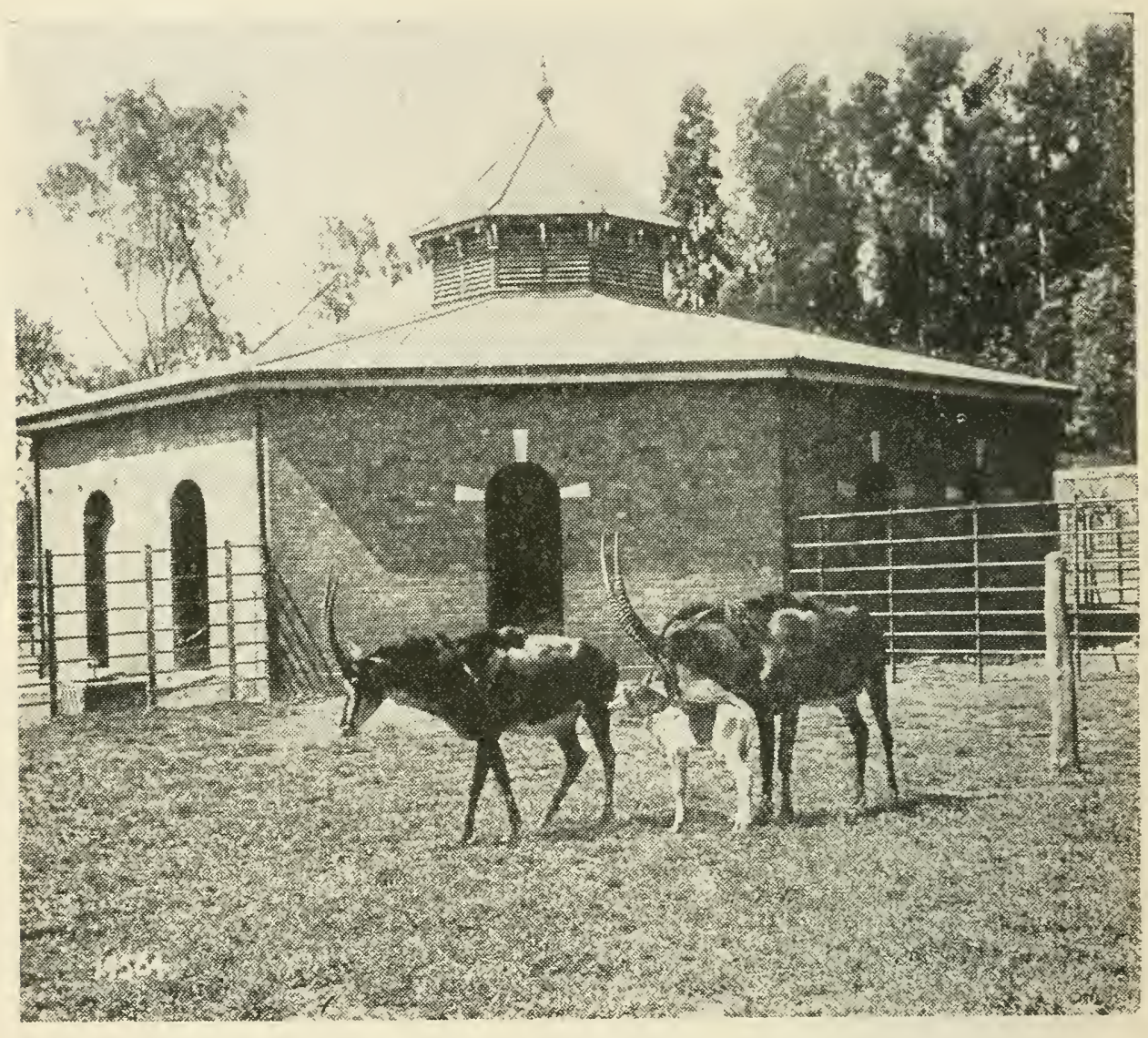

FIG. 112.- Sable Antelopes and Young.

our limits are concerned. In habits it somewhat resembles the Roan, but seems to prefer sparsely-wooded high veld, interspersed with thick groves wherein to take shelter; it is, however, occasionally found in thickly wooded country. It is largely a grass feeder, and drinks regularly, so is never found very far from water. It is 


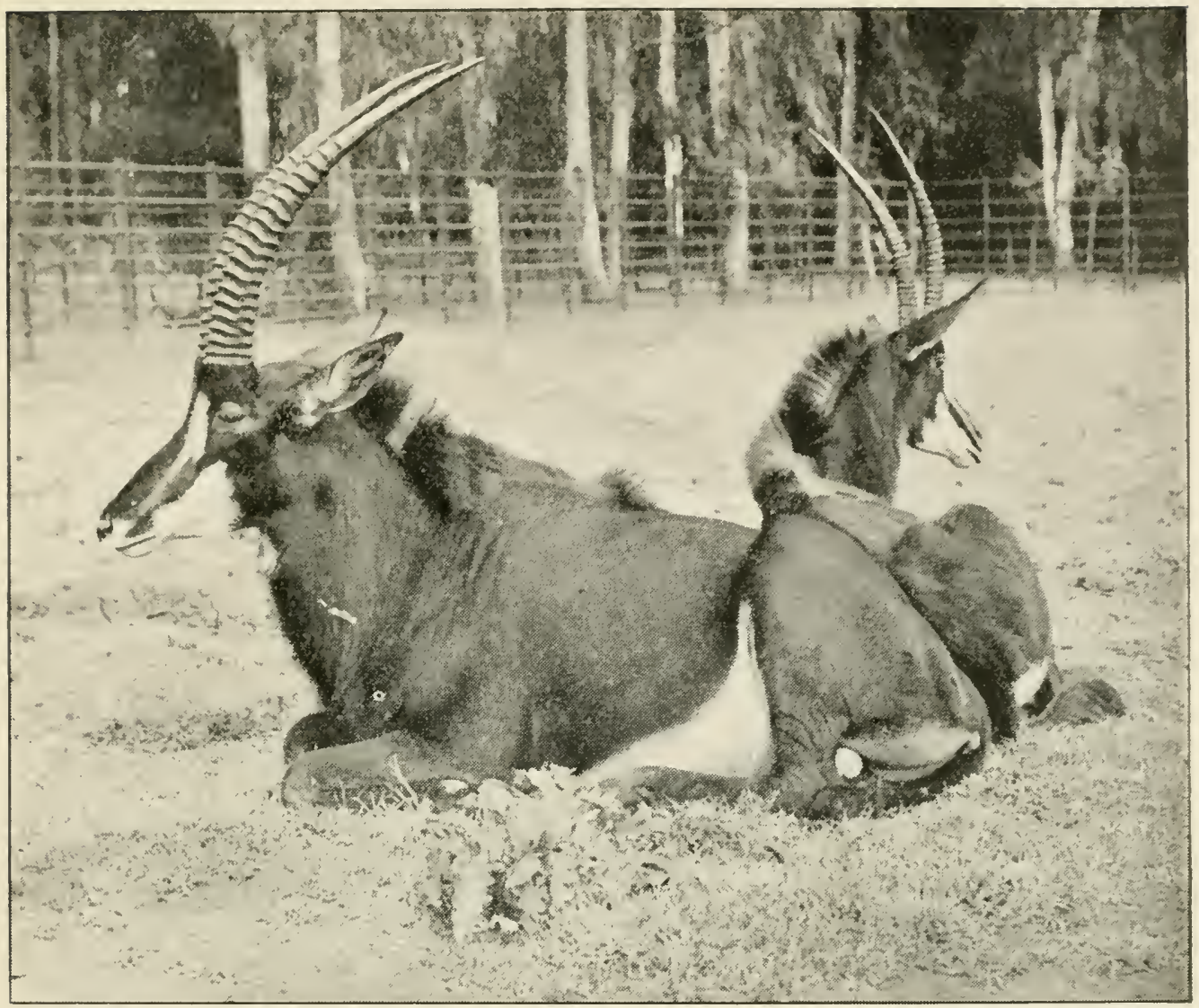

F1G. 113.-A pair of Sable Antelopes (young adult).

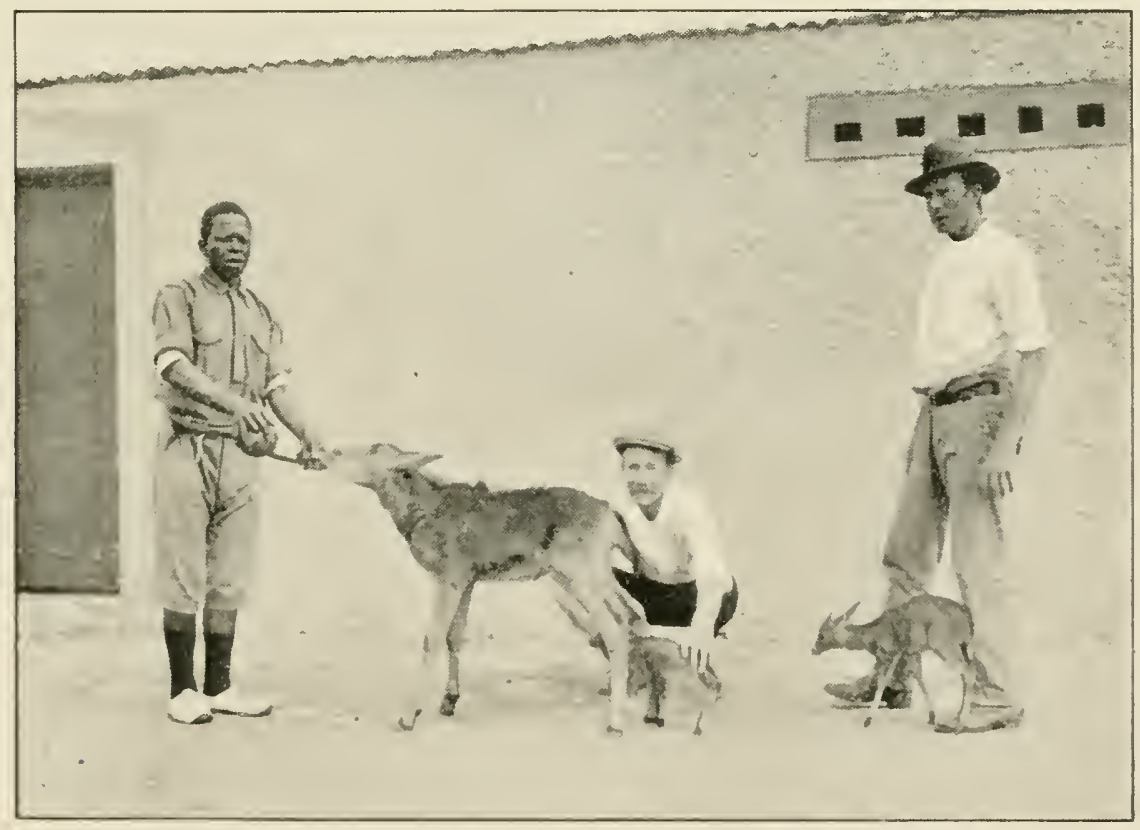

FIG. 114.-Baby Sable Antelope (and baby Duikers). 
more gregarious in habits than the Roan, being found in herds of varying number up to forty or fifty individuals. Old bulls are usually found alone, and young bulis in small troops. The calves are born in late summer, and Major Hamilton gives the period of gestation at 270 days, which I am not able to verify, except that in captivity

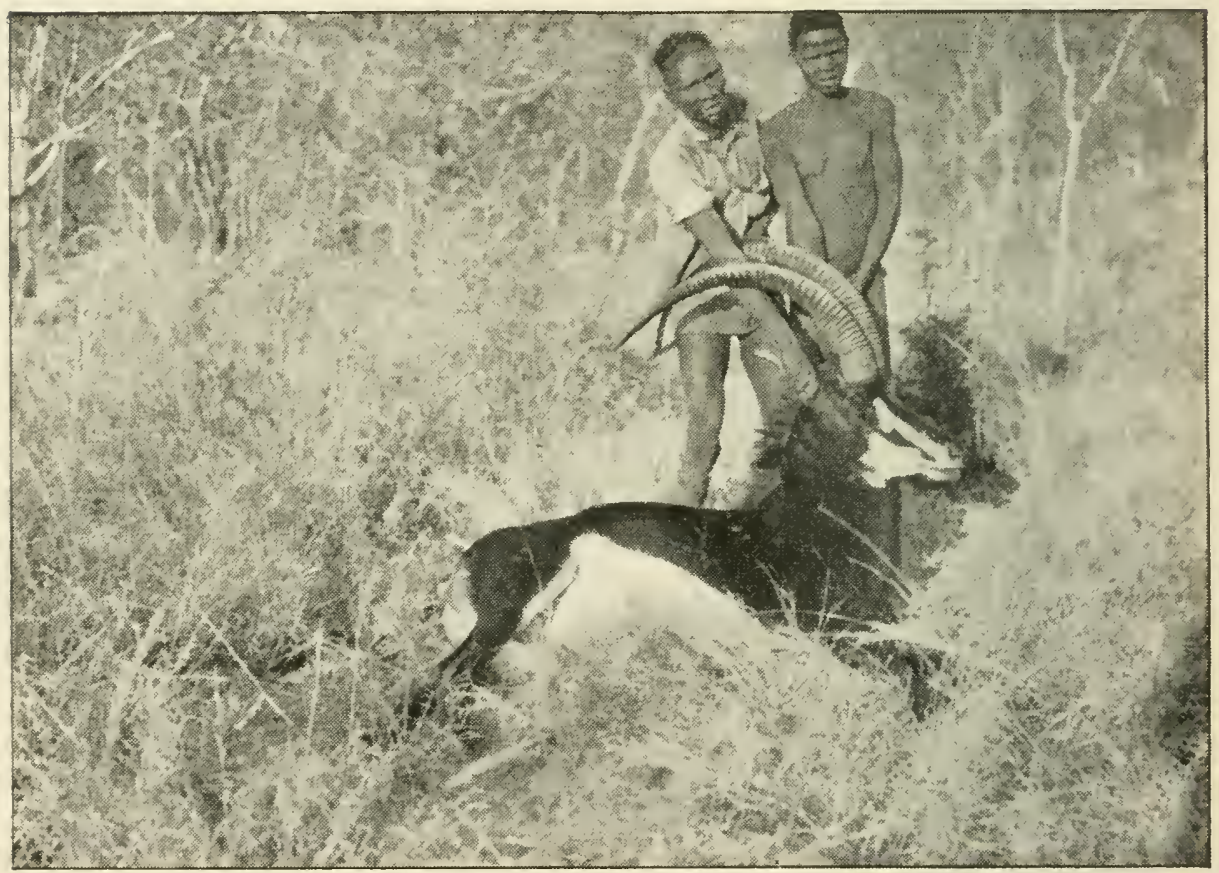

Fig. 115.-Dead Sable Antelope Bull.

only one young one is born annually. They give vent to a snort when alarmed or angered.

The Sable is a dangerous animal when wounded. A male in the National Zoological Gardens, though tame enough when unmolested, became very fierce when meddled with. It breeds well in captivity, one young one being produced at a birth. 


\section{Genus ORYX.}

Large antelopes with large tufted tails, false hoofs and forwardly directed manes; horns ringed at the bases long and, in the case of the only South African species, almost straight.

\section{Oryx gazella. Gemsbuck. Gemsbok.}

Trutiama (Bechuana).

Colour a tawny grey ; face brown, black, and white, the white eye-stripe being cut off from the muzzle by the joining of the dark nose streak with the black cheeks. A dark brown line below the lower meridian line of the neck, dividing at the base into a longitudinal band on either side of the body, thence on to the hips. A tuft of dark brown hair on the throat. The limbs are white, with a broad dark patch about the knees and hocks. Height, 3 feet 9 inches to 4 feet; length, 5 feet 3 inches ; tail, 1 foot 3 inches. Horns long, straight, sharp and spear-like, those of the females being as a rule longer and finer; length, 40 to 45 inches (record, 48 inches).

The Gemsbuck is fond of open sandy desert country, being found in the dry districts of North-IVestern Cape Colony, the Kalahari and the South-WVest African Protectorate to Western Matabeland as far as the Chobi River. It lives in pairs or small herds, feeding upon bulbs, wild melons, small bushes and such-like. It can, in consequence, go for a long time without water, and is more or less independent of this, to us, necessary commodity. It is of a wary nature, and very fleet. This is to me one of our finest Antelopes, the graceful, compact build and beautiful head making it a regal-looking animal. One pair in the National collection bred very well, the female giving birth to a calf for three successive years, 


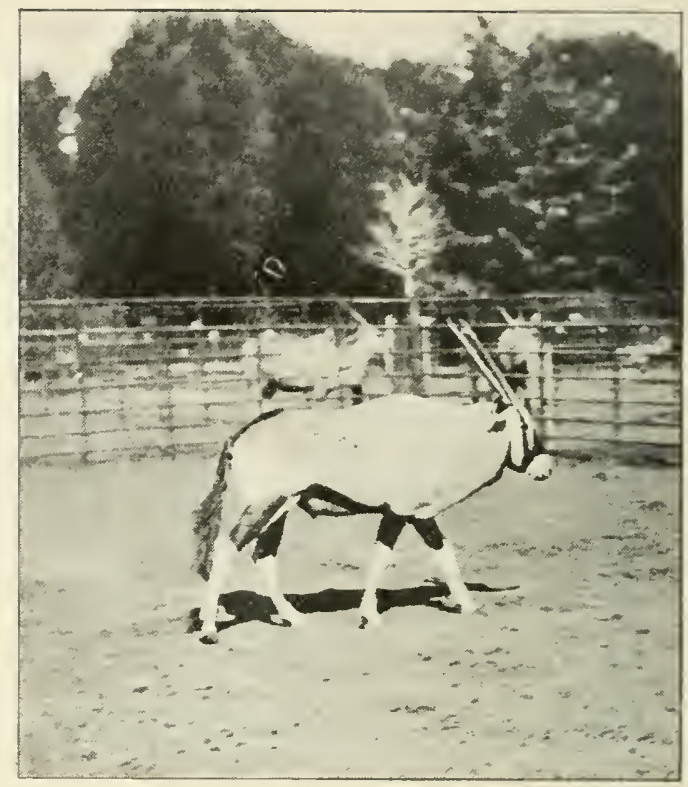

FIG. 116.--Gemsbuck.

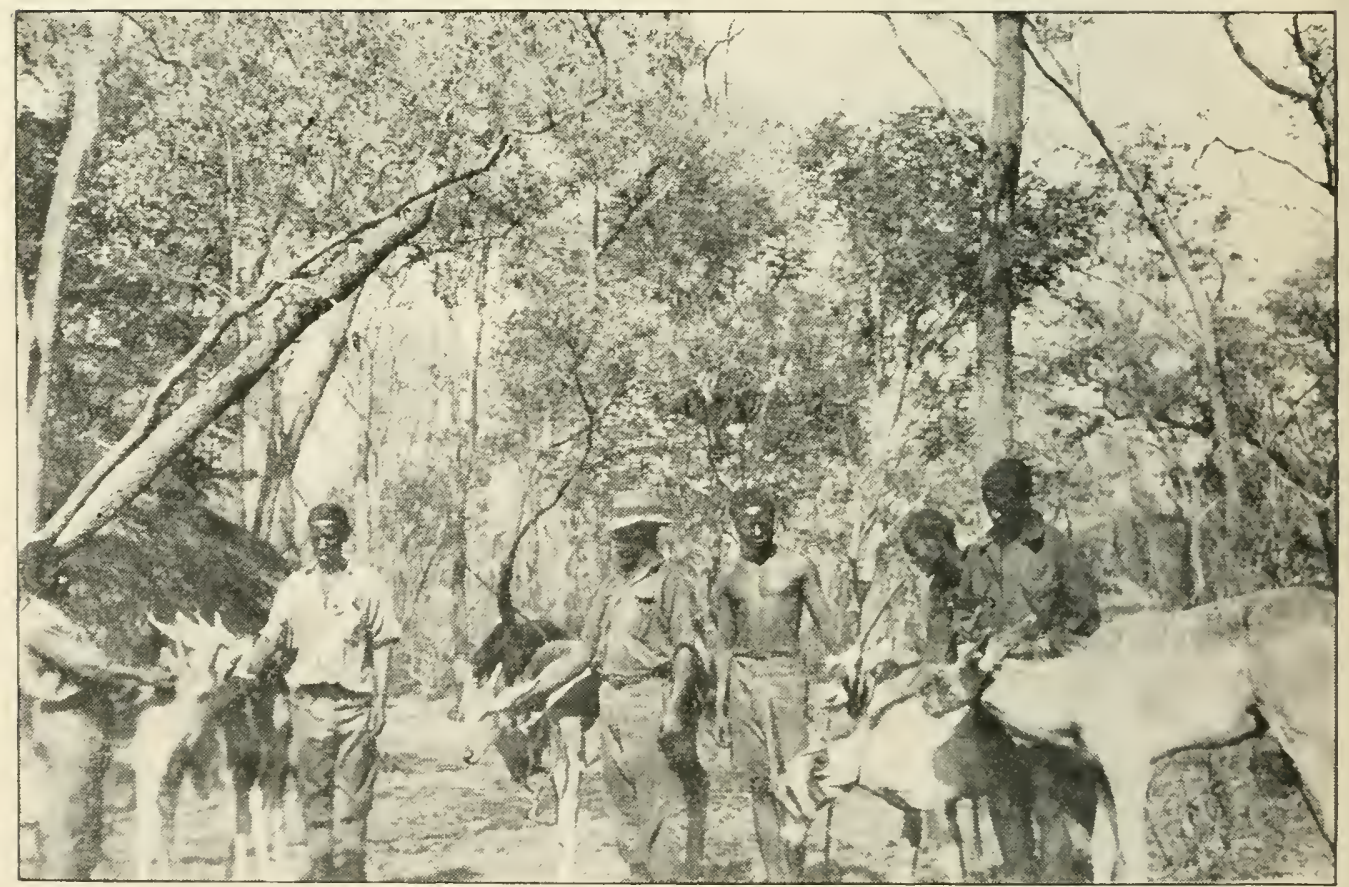

FIG. 117.-Freshly-caught young Gemsbuck and Eland being brought into camp. 
when unfortunately both parents were carried off by stomach troubles, following bad cysticercus infection. The bull was most pugnacious, refusing to make way for anyone. He had to be caught and thrown periodically, as his hoofs grew extremely long, which had in consequence to be regularly cut. The cow was, on the other hand, very docile and tame. All our Gemsbuck came from Bechuanaland, either from Kuruman, Vryburg or Khama's country.

\section{Genus TRAGELAPHUS.}

Medium sized Antelopes, with fairly short, bushy tails. The males only are horned; the horns are slightly ridged and spirally twisted upwards and outwards.

\section{Tragelaphus sylyaticus. Cape Bushbuck. Bosbok.}

Inkonka, male, Imbabala, female (Swazi and Zulu); Mbabala (Barotse); Ibavara (Lower Zambesi).

The male is dark slatey brown, forehead reddish. Lips and chin, a spot below the eye, crossbars on the throat, patches on the insides of the legs and a few scattered spots on the body, chiefly on the flanks, all white. A short upstanding mane runs along the back. Tail white below. The female is of a more reddish colour than the male, and usually striped. I append a photograph of an authentic pair of horns taken from a female Bushbuck. Such cases are rare however. Horns 12 to 16 inches long, straight and black, forming one or one and a quarter spiral curves. 'The record for the South African variety, so far as I can make out from Rowland Ward's "Records of Great Game," is $18 \frac{1}{2}$ inches; height, not quite 3 feet; length, 4 feet 9 inches; weight, from $100 \mathrm{lb}$. to $150 \mathrm{lb}$. The Transvaal specimens seem to be paler and redder 
than those from the Cape, and may require a new subspecific name.

This buck, of which the male is a noble-looking animal, is an inhabitant of thick forest or bushy kloofs, feeding as a rule only at night or during the early morning. It is only found singly, in pairs, or with the season's kid in attendance. The male gives vent to a

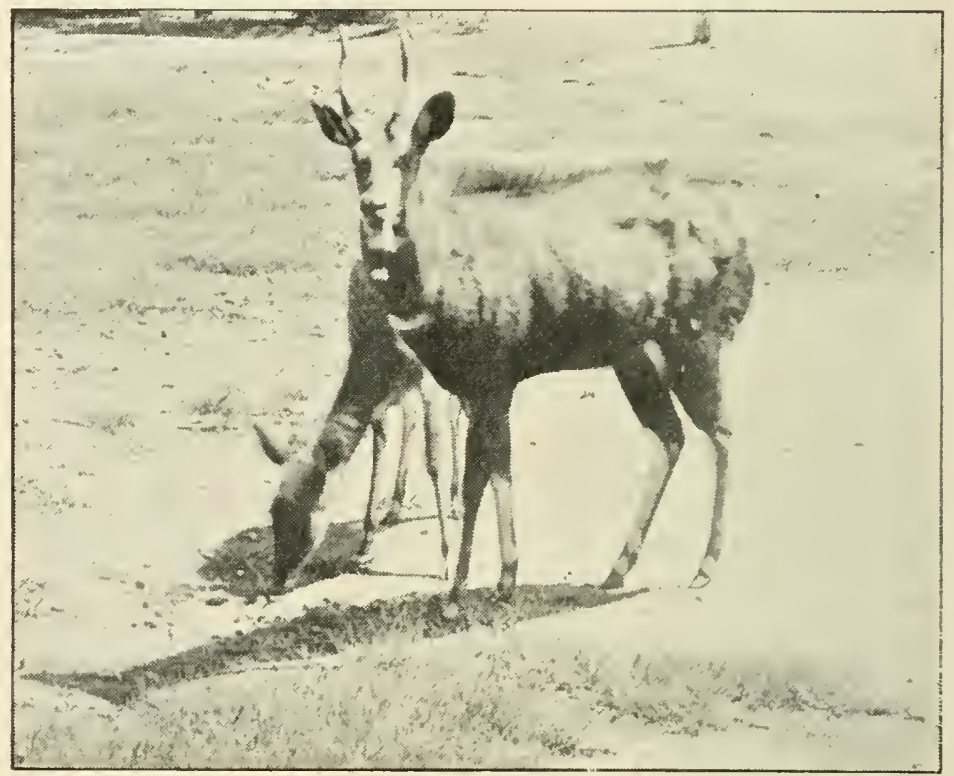

FIG. 118.-Cape Bushbuck.

hoarse, barking note, and is a vicious animal when wounded. The Bushbuck feeds upon leaves, grass, \&c. It ranges through the southern and eastern districts of the Cape, Natal, Zululand, Portuguese East Africa and Eastern Transvaal. In Northern Rhodesia and Central Africa it is replaced by a closely allied form, the Harnessed Antelope (Tragelaphus scriptus), which is of a paler and redder colour, and is, as its name implies, prettily marked with white stripes upon the body and spots upon the throat and hips.

In captivity the male Bushbuck is usually a most 
aggressive animal, butting human beings and other animals with impartiality. In fact, it is difficult to breed them, as, unless they are paired up when young, the rams kill or severely injure the ewes. Several rams in the collection absolutely refused to have a mate, and, after they had killed and injured several females, were left in solitary confinement. A few have been bred in the Gardens, one young one being born at a time.

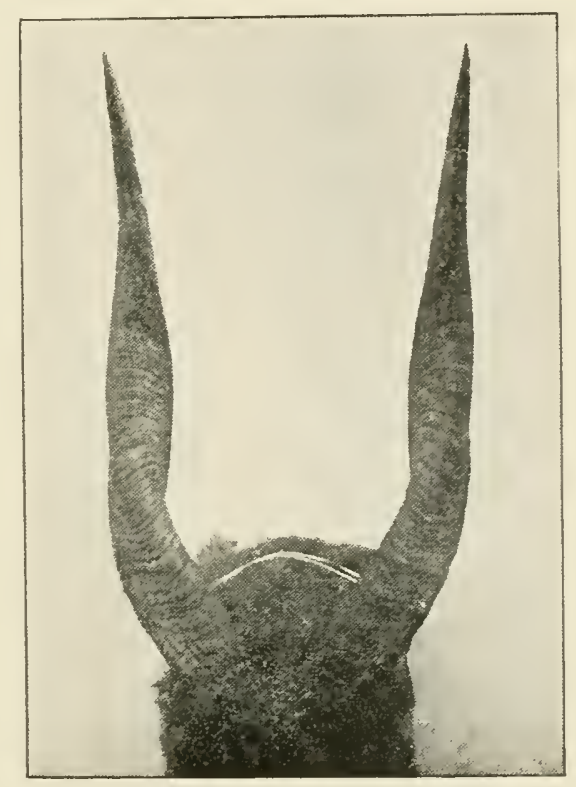

Fig. 119.-Horns of female Bushbuck.

\section{TRAGELAPHUS ANGASI.}

(Genus BOOCEROS, Trouessart.) 'Nyala. Bastari Koedoe. 'Nyala (Zulu and Swazi).

Male of a grey-brown colour, inclining to chocolate brown on the neck, face, and above the knees and hocks. Forehead and legs below the knees tawny-chestnut. (Sclater describes it as sienna-brown). There is a white chevron on the nose, and several white spots on the cheeks; chin, front of upper lip and lower throat, white; ears reddish with black tips. The neck is covered with 


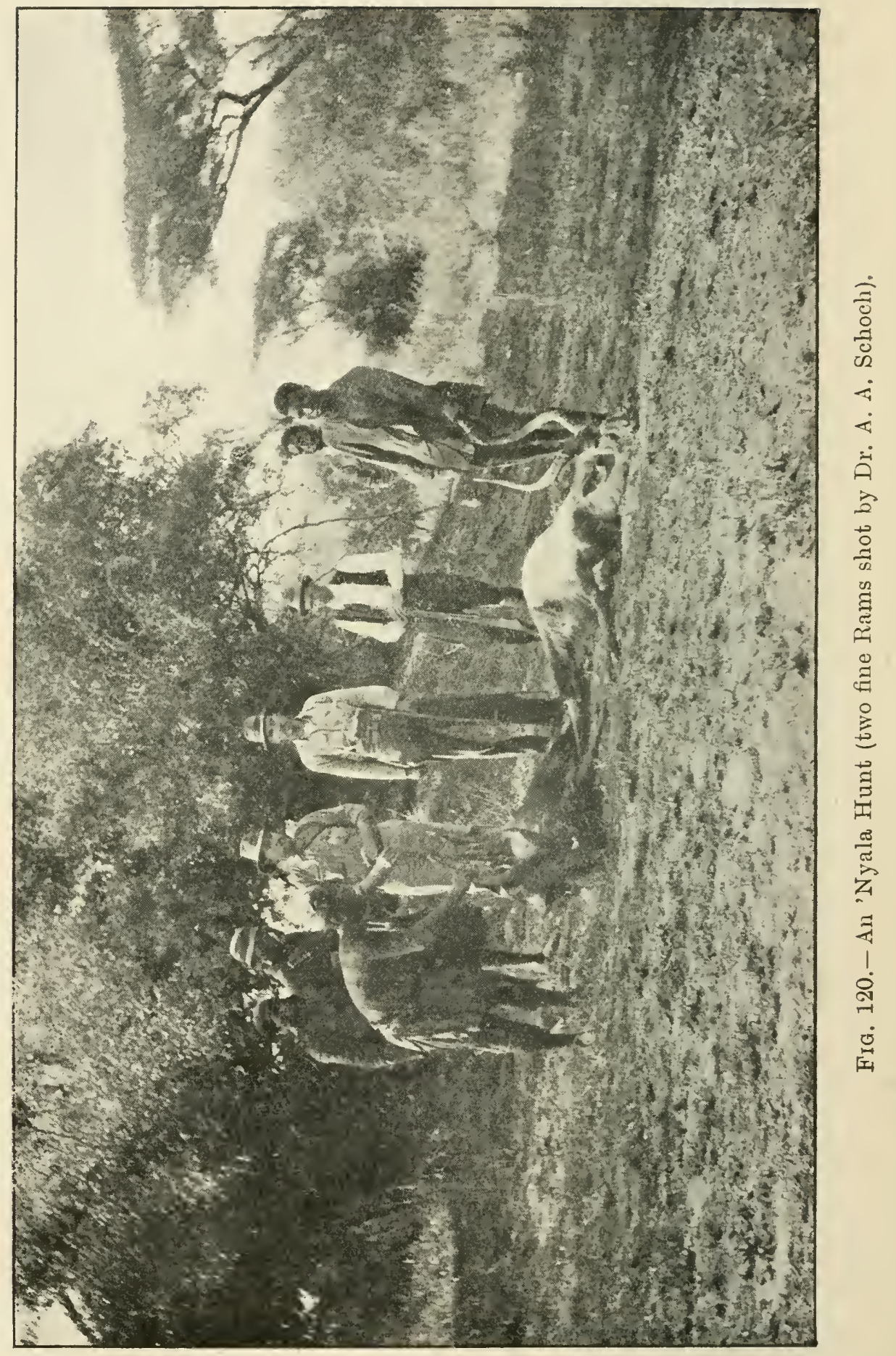


long, dark hair, which extends along the belly and haunches to the knees. 'There is a white tuft on the dewlap (which is arranged in the shape of a whorl or crown), another under the belly, and one on the flanks

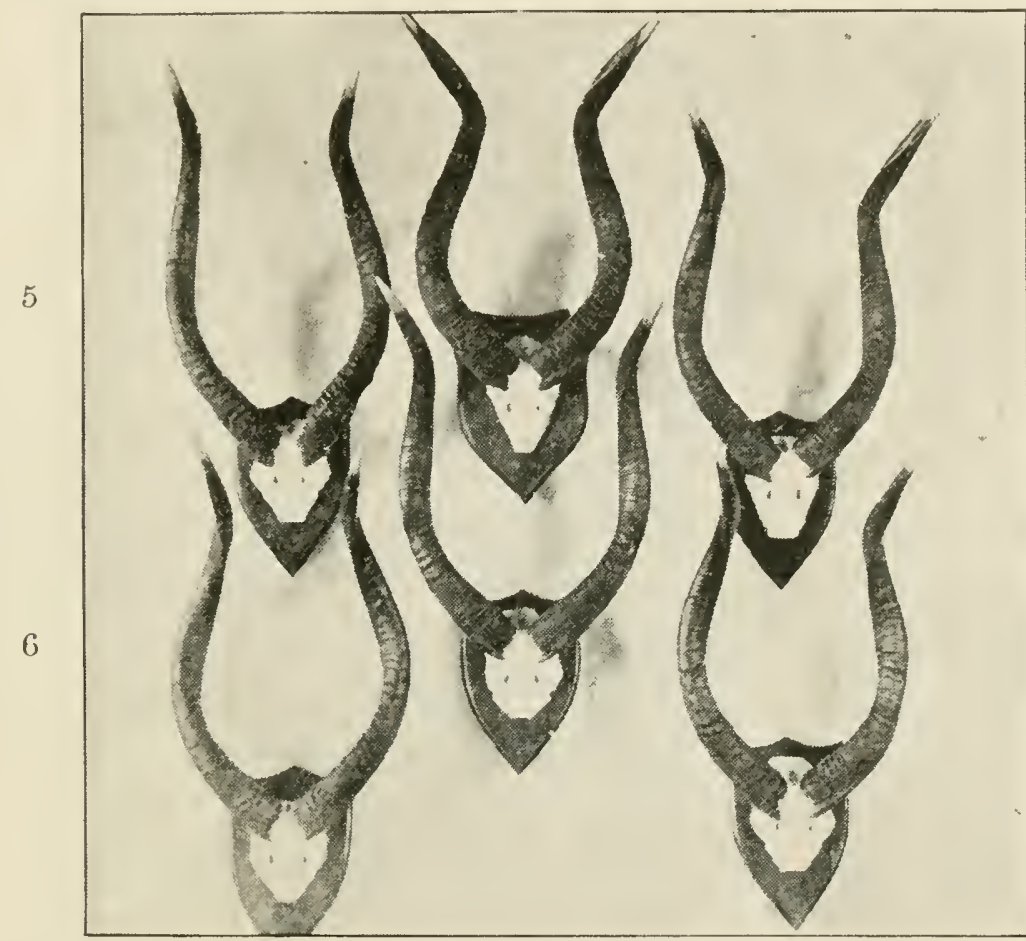

2

FIG. 121.-A fine series of 'Nyala horns.

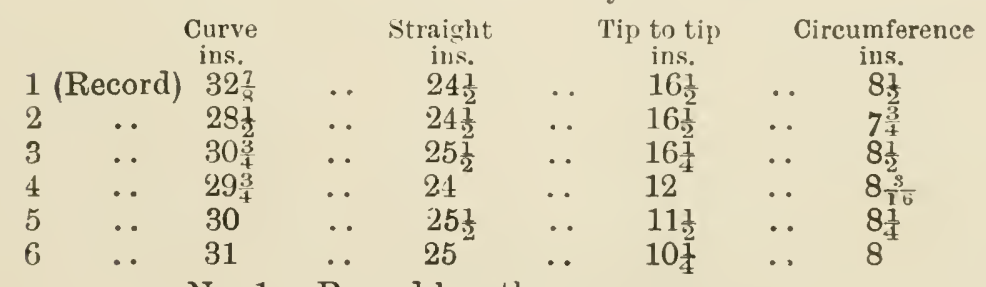

No. 1.-Record length over curves.

Nos. 3 and 5.-Longer in straight line.

and thighs. A black mane extends as far as the shoulders, and from thence to the rump, is replaced by a white mane. The body is marked by twelve to fourteen somewhat indistinct white bars running round the barrel. 
The hips are adorned with a few white spots. The fetlocks and feet are black. The tail is bushy, black above and white below, and reaches to the hocks. Length of head and body, 40 inches (Sclater); 51 to 60 inches (F. O. Noome) ; height at shoulder, 42 inches; length of horns from 2.2 to 30 inches. Record $32 \frac{7}{8}$ (Lourenço Marques, F. O. Noome). The horns are much larger, wider, and thicker than that of the Bushbuck's, and are brown in colour with conspicuous pale yellow tips. The female is much smaller than the male, has no horns, and is of a bright, reddish, tawny colour, almost an orange; paler below and on the insides of the legs. A distinct black dorsal line runs along the back from the crown of the head to the root of the tail. She has usually more white stripes on the sides, which are also more distinct than those of the male. There is a black line on the face but no white chevron. MIr. F. O. Noome of the Trans. vaal Museum possesses a pair of horns which adorned a female Nyala, which is the only case so far known.

The head of an 'Ayala, with its manes of long hair' both above and below the neck, its grand carriage and fine horns, is to my mind, one of the finest trophies of the hunter. It is, however, very local in habit, being found only in the more well-watered and thickly wooded and low lying tracts of Zululand, Portuguese East, Africa. (north and south of Delagoa Bay) and north of the Zambesi on the western bank of the Shire River. The Transvaal Museum obtained a number of fine specimens in the N'Kuzi Game Reserve of Zululand, and at Matopi on the Maputo Rirer, and Mr. F. O. Noome of that Institution possesses the record pair of horns, of which I append a photograph. These animals are becoming very scarce in some of their old haunts, as the writer found to his cost in August, 191s, when he spent a few 
days in the bush at Port Henrigue on the Tembe River in Maputoland south of Lourenço Marques, without procuring a specimen. I heard them snorting once or trvice, and saw a fair amount of spoor, but time was too limited to spend more days in the bush.

The 'Nyala feeds most during the night, and hides in some dense thicket during the day, and if you want to

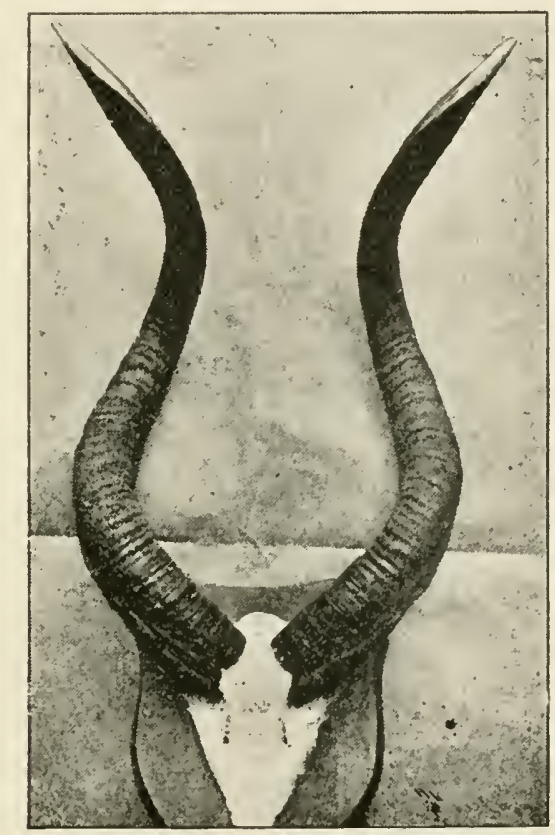

FIG. 122.- Record pair of 'Nyala horns.

catch him on his way back from the feeding grounds or watering place you must be up with early cock-crow. Your best chance of a shot is between dawn and sunrise. 'The 'Nyala goes about in small herds of from five to fifteen individuals, consisting either of both sexes, a few females accompanied by an old ram, or a few rams together. It feeds upon leaves, grass and roots, and has a simlar snorting bark to that of the Bushbuck, only deeper and louder. The female gives birth to a single 
young one during the spring and summer months. Mr. Wm. Campbell of Mount Edgecombe, Durban, informed me that he caught a young one in Zululand in early August, which is now in the Durban Zoo.

\section{IRAGELAPHUS SELOUSI.}

(Genus LYMNOTRAGUS, Trouessart.) Sitatunga. Water Koedoe.

Sitatunga (Barotse); Nakong (Lake Ngami).

'This Antelope is a geographical race or sub-species of the East African Marsh Antelope (Tragelaphus speliei).

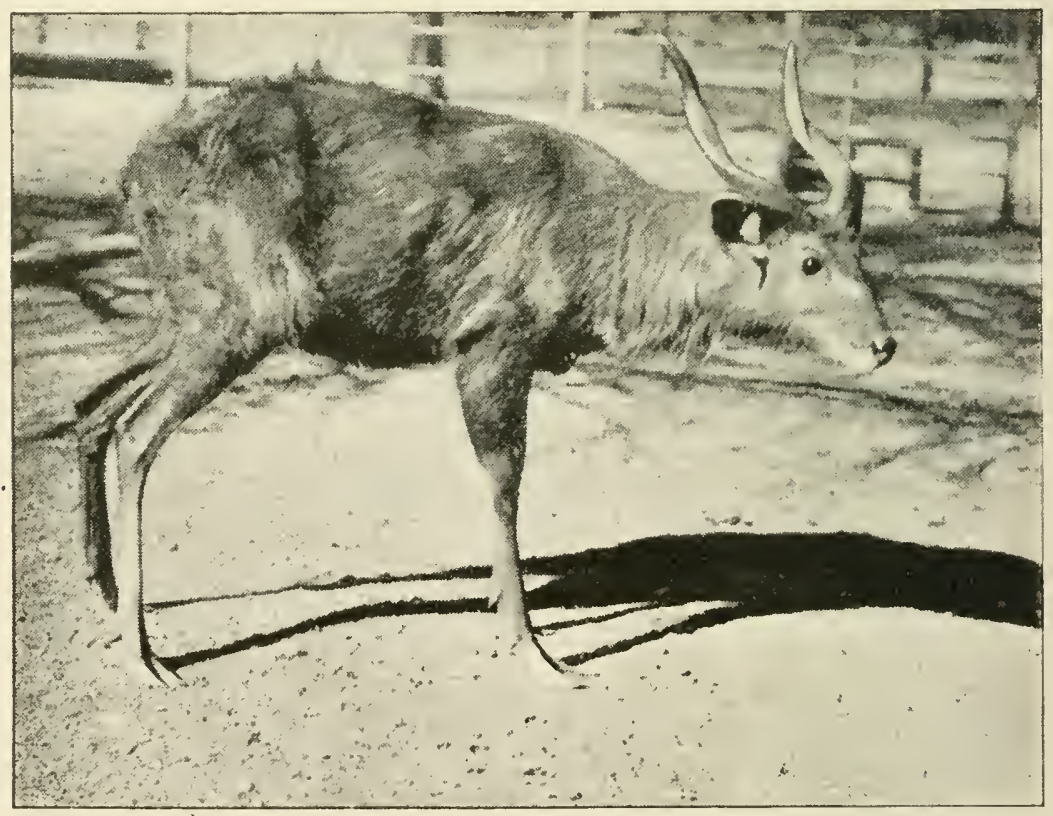

FIG. 123. - Sitatunga Ram.

It is mouse-brown or dark grey-brown in colour, the hair being fairly long and woolly, which together with its awkward figure and stupid-looking face, gives the animal an untidy appearance. There is a white $V$-shaped mark on the face, a white spot on the chin, and one 
below the eye: two indistinct transverse white marks on the neck, and the sime on the insides of the legs about half-way down. 'The ears are short and broad, with a white patch at the base, and a tuft of white hair along the inner margin. The tail is short and slender, brown above and white below. 'The feet are very elongated, the space between the false and true hoofs being devoid of

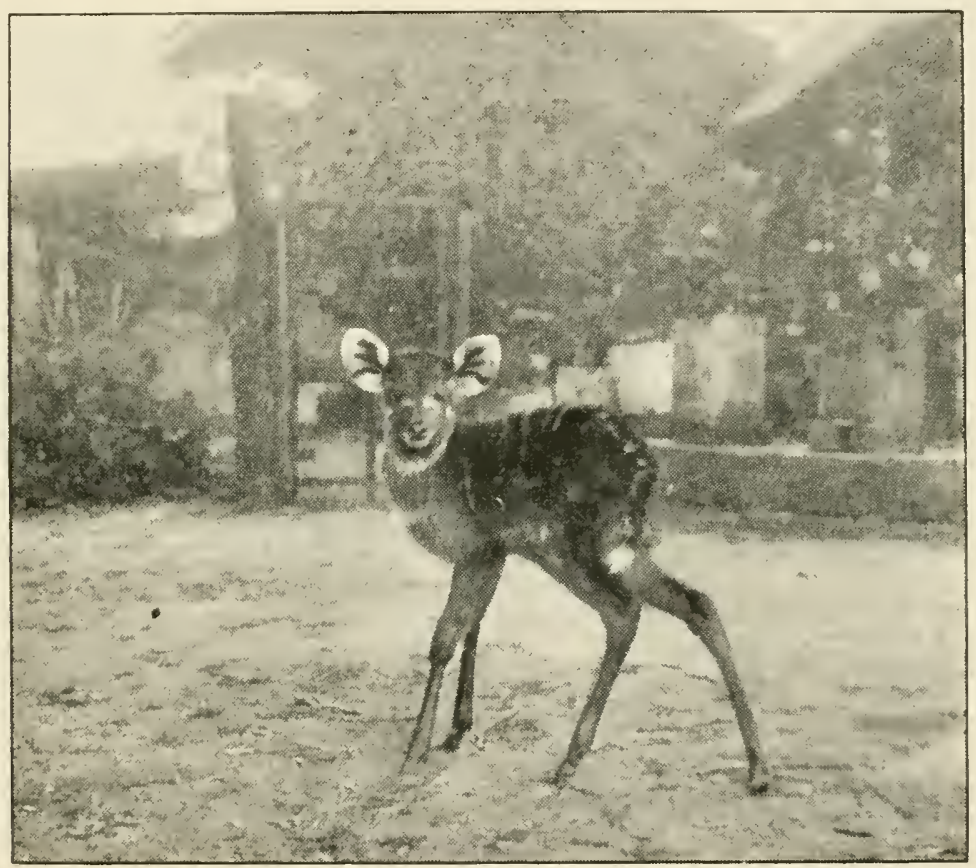

FIG. 1:24.-Young Sitatunga Ewe.

hair. The ungainly looking feet of these Antelopes are well placed, as it is an inhabitant of marshy ground. Length of head and body 5 feet 3 inches. Height at shoulder 42 inches. Horns rather more twisted than that of the 'Nyala, and about 28 inches in length along the curve (22 inches in a straight line). Records: 325 inches along the curve, 27 inches straight (F. C. Selous); $35 \frac{7}{5}$ inches on the curve (Lord Rothschild). The sexes are alike, except that the female is hornless. 
It inhabits the swamps and marshy river banks of Lake Ngami and Chobi River areas within our limits, and beyond Zambésia, the regions of Lake Mweru and Bangweolo. Dr. Livingstone first met with this antelope on the Zambesi in 1852 , but it was not until 1864 that the northern form was described, and in 1898 the southern form was separated and named after Selous by Rothschild.

The Sitatunga lives in pairs or small parties amongst the reedbeds of the lakes, swamps and rivers, hiding during the heat of the day, and feeding upon the young shoots of reeds, grass, dic., at night. Owing to the peculiar structure of its feet it can walk easily on the tangle of aquatic weeds and grass in its favourite haunts, but is very clumsy on dry land. When pursued it takes to the water and swims well. Its flesh is said to be highly flavoured and not very palatable.

We have posesssed two rams of this species in the National collection, one that lived for five years, and died of an abscess in the pelvis, and a second which unfortunately arrived with a broken hip and had to be destroyed. Both came from near Jivingstone, Northern Rhodesia. A ewe now in the collection came from the Kafue River and was presented by Mr. Ben Woest of Mazabuka.

\section{Genus STREPSICEROS.}

Large antelopes resembling the last genus in general characters, but the horns, which the male alone carries, are enormously long and form several complete spirals. Ears large. Antorbital gland small. 
Strepsiceros capensis. Koodoo or Kudu. Koedoe.

Itolo (Basuto); Nschlongololo (Swazi and Zulu); Noro (Mashona); Tolo (Bechuana and Barotse).

Colour, a pale drab-or ash-brown, greyer in old males, owing to the skin showing through the thin hair. A

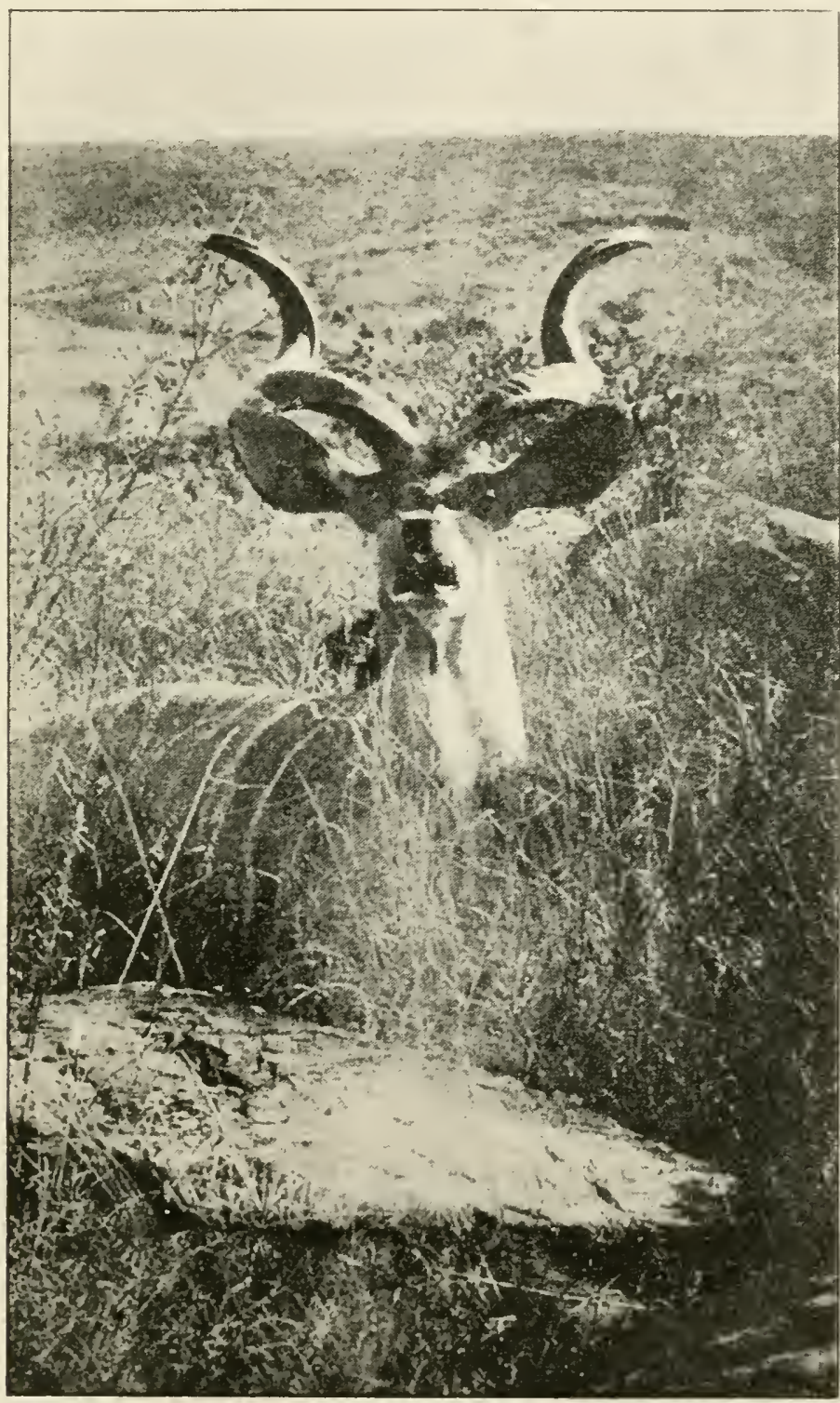

Fig. 125.-Koodoo Bull surprised in his home!

$V$-shaped mark on the face, spots on the cheeks, lips and chin, white. The breast and front half of the belly 


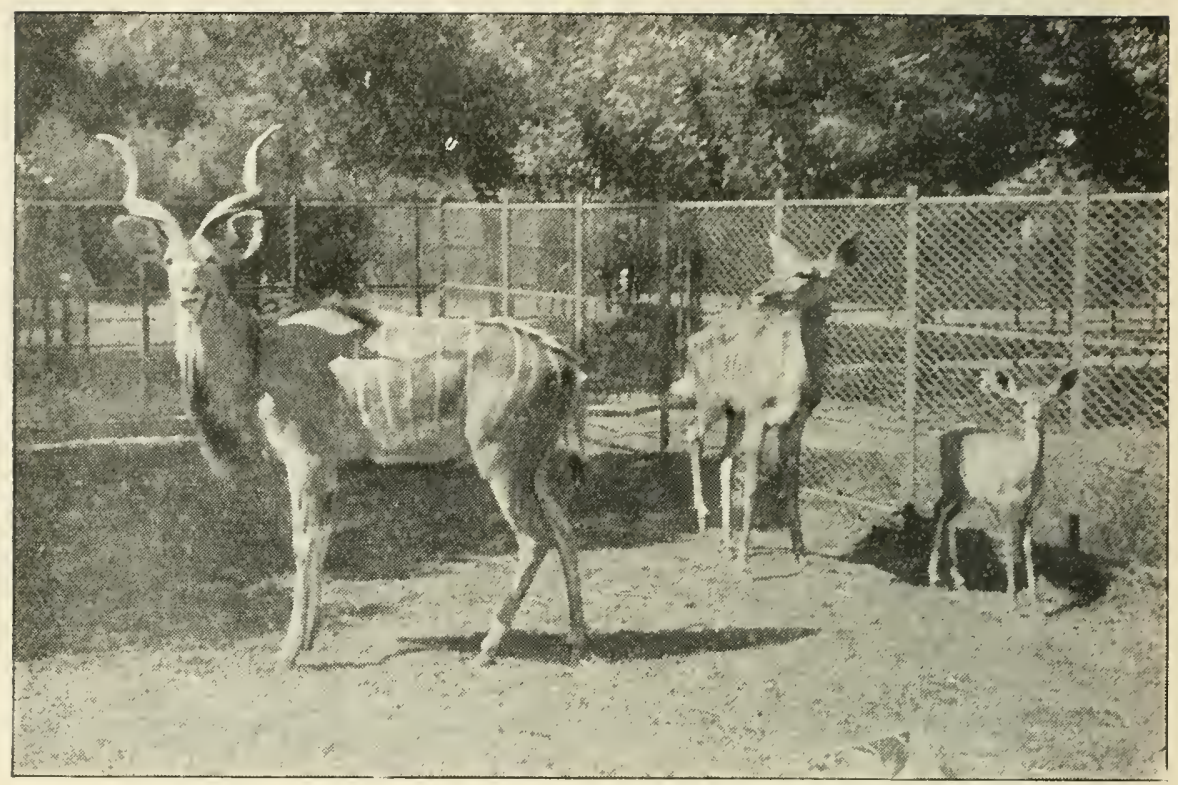

Frg. 126.-A Kioodoo family.

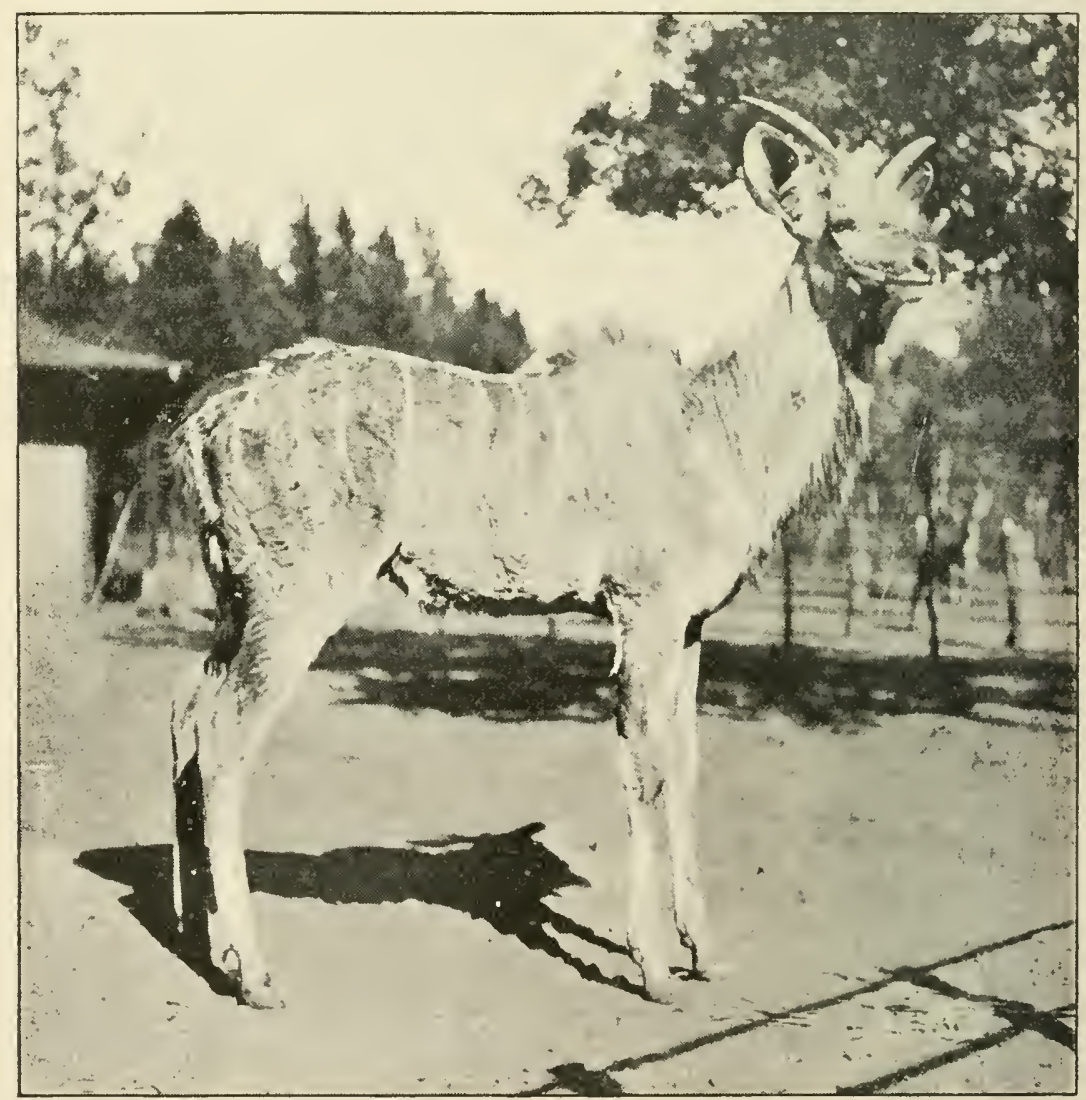

FIG. 127. - Young Koodoo Bull. 
is dark brown. 'The body is marked with six or seven transverse white stripes. 'The tail is bushy, grey above and white below. Length about 8 feet. Height 54 to 60 inches. Horns from 40 to 48 inches in a straight

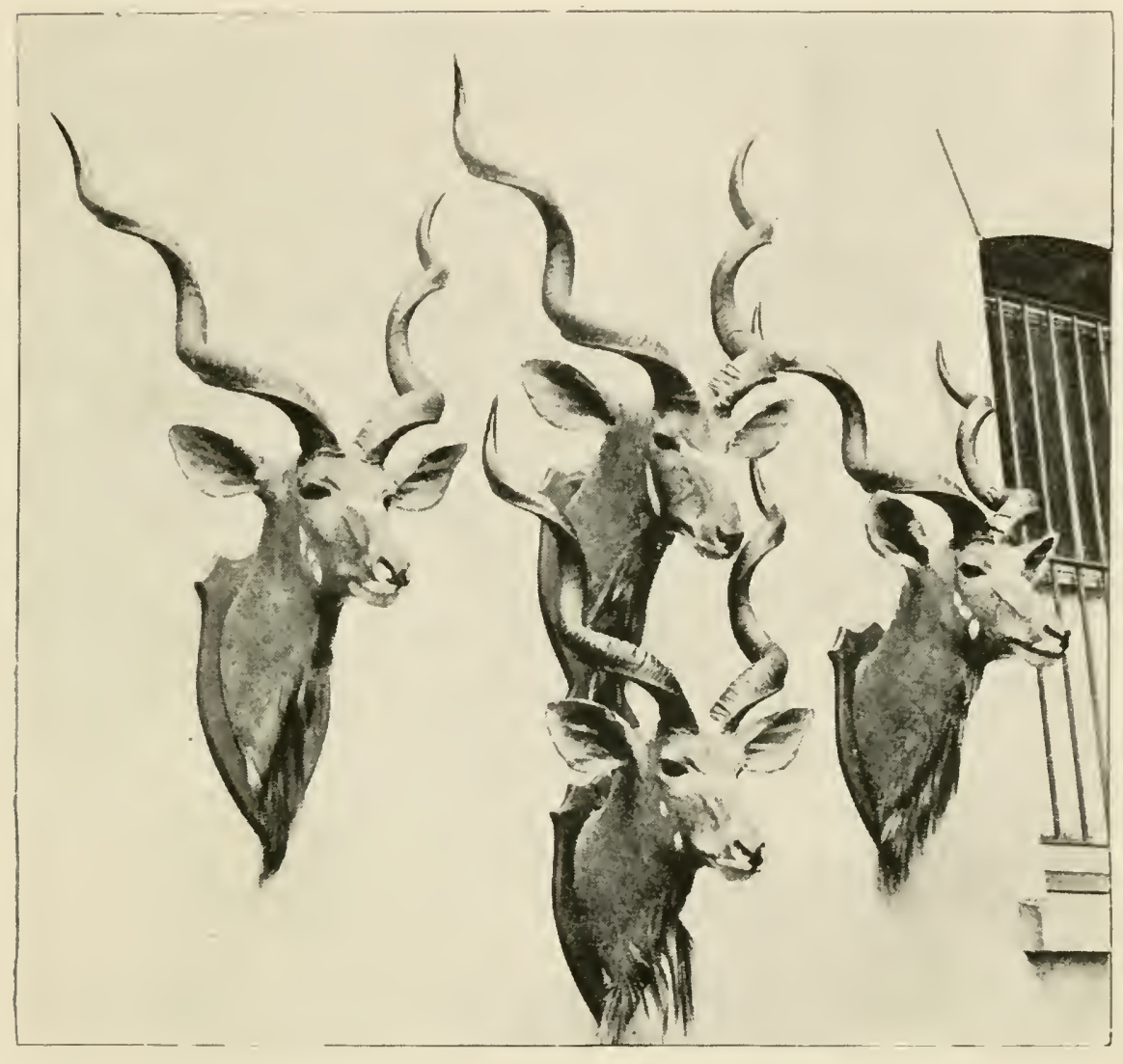

Fig. 128. - Series of heads from N. Transvaal to show variation in face markings.

line; 50 to 64 inches along the curve (Rowland Ward's Records). Records: $67 \frac{1}{2}$ inches, R. M. of Lydenburg (author's measurements); 71.12 inches over the curve and 523 inches in a straight line, Mr. Cole-Rous, Johannesburg (J. R. Ivy). 'This last magnificent pair' of horns was obtained in Secucuniland, Lydenburg district, in August 1916. A fine bull weighed by Dr. Schoch was $705 \mathrm{lb}$. 
The Koodoo inhabits most territories of South Africa where there is a forest or thick bush, as it is essentially a bush-loving buck, like the members of the preceding genus, although it often seems as partial to the bush of rocky hills, as to that of the wooded river banks. It is found in small herds of from half-a-dozen to a score of animals. Old rams may be found alone, or in parties of two or three consorting together. It is essentially a browser, feeding upon the shoots and leaves of shrubs

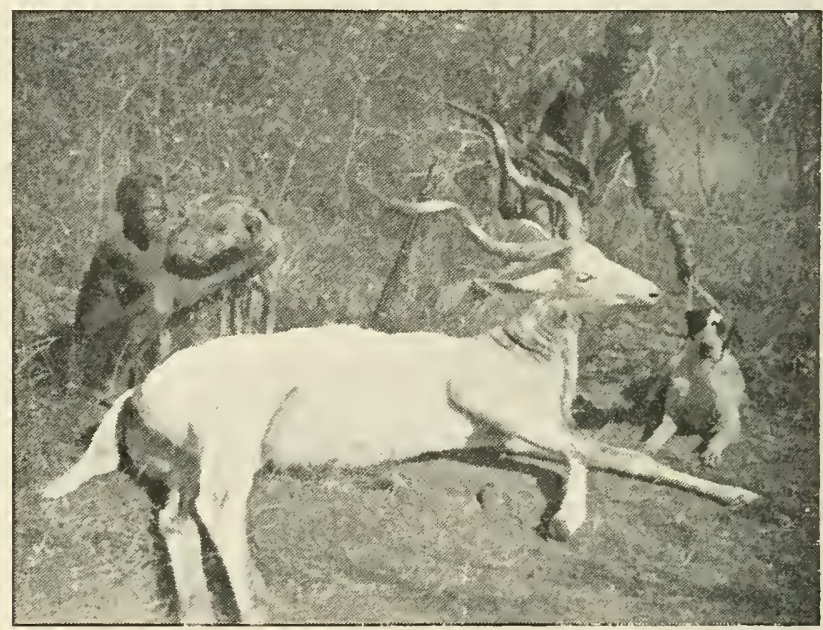

FIG. 129.-Albino Koodoo (South West Prot.).

and bushes, and their fruit; also seeds. It is of a somewhat timid nature, with no great turn of speed in flat open country, where however it seldom allows itself to be caught. It is still fairly common in the Addo Bush and other wooded portions of the Albany and Uitenhage districts, and is plentiful in the Eastern and Northern Transvaal, especially in the Sabi Reserve and some parts of Zoutpansberg. The call is a hoarse bark resembling that of a Bushbuck, but is much louder and deeper. The young ones are hidden by the mother in long grass or dense thicket. This animal has bred in the National Zoo last year for the first time. One calf was born on the 30th November, and is doing well. 


\section{Genus TAUROTRAGUS.}

Both sexes horned. A large dewlap present. 'I'he largest Antelopes in Africa. 'T'ail ox-like and tufted.

Taurotragus oryx. Eiland. Eland.

'Itpofu (Barotsi and Ngami); Mofo (Mashona); Pofo

(Bechuana); Muzefu (Mashukulumbwi).

Colour tawny or drabbish brown; on the forehead there is a bunch of upstanding hairs. 'The neck is

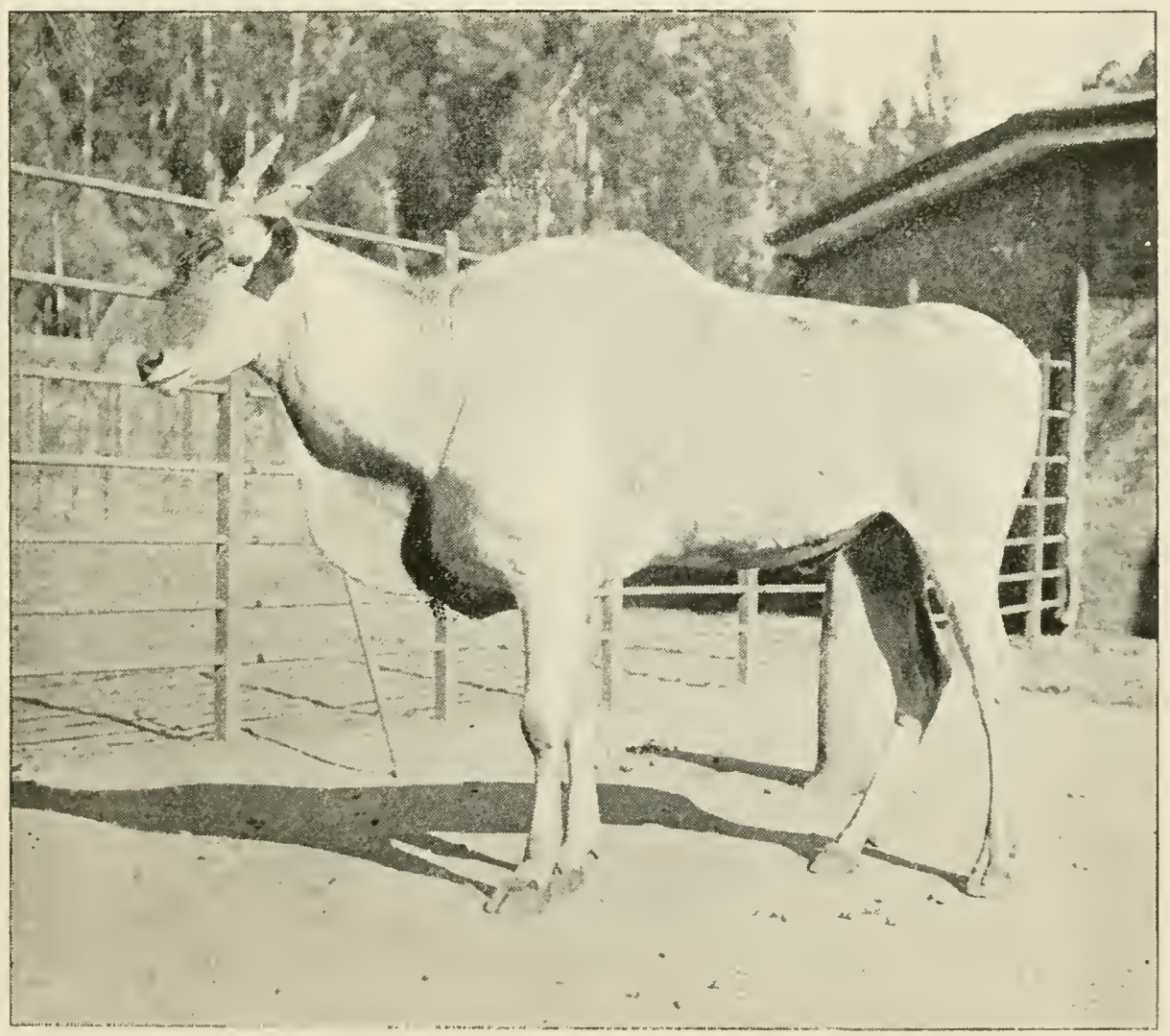

FIG. 130.-Unstriped Eland Bull.

thick. There is a dark line along the back, and ten or twelve transverse white stripes on the sides of the body. The female has lighter horns, is smaller than the male, and is without the brush on the face, and has not such 


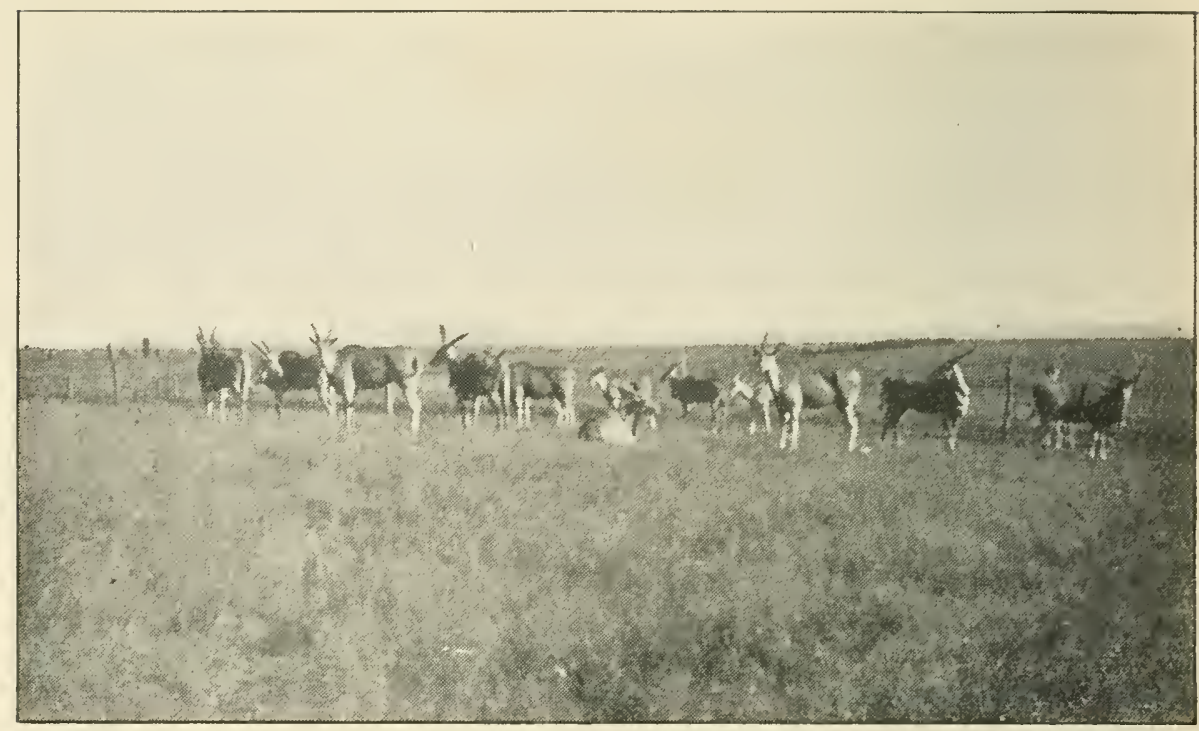

FIG. 131.-Herd of Eland on C. Newberry's farm, Clocolan, O.F.S.

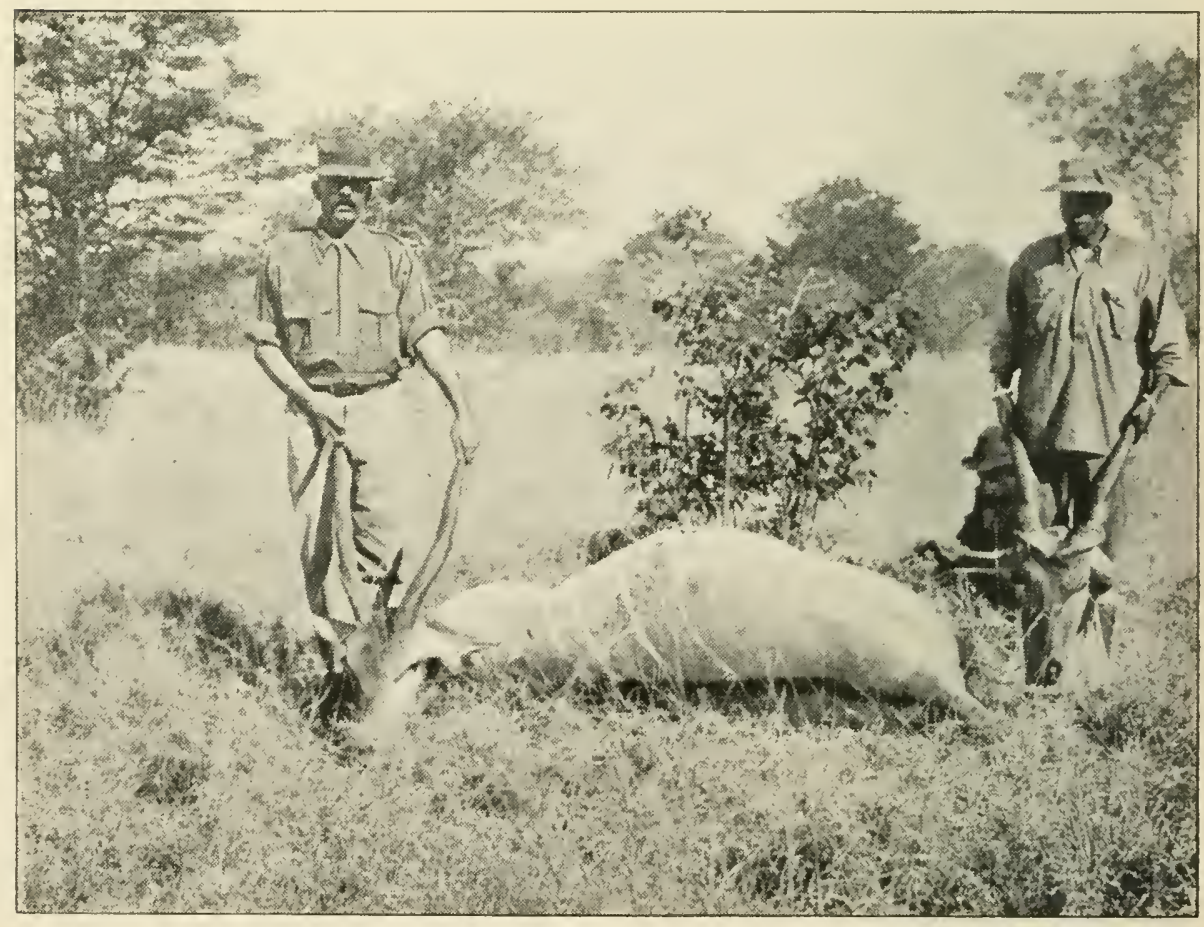

FIG. 132.-Striped Eland (Northern variety) 
a heavy neck. The horns are short and stout, with a twist in the lower half. Length 2 feet to 3 feet. Record 37 inches. Height 4 feet 9 inches to 5 feet 10 inches. Length of head and body about 10 feet.

The Southern Race (Taurotragus oryx oryx), which is now only found in a wild state in the Giant's Castle Reserve of Natal and the Northern parts of the Kala-

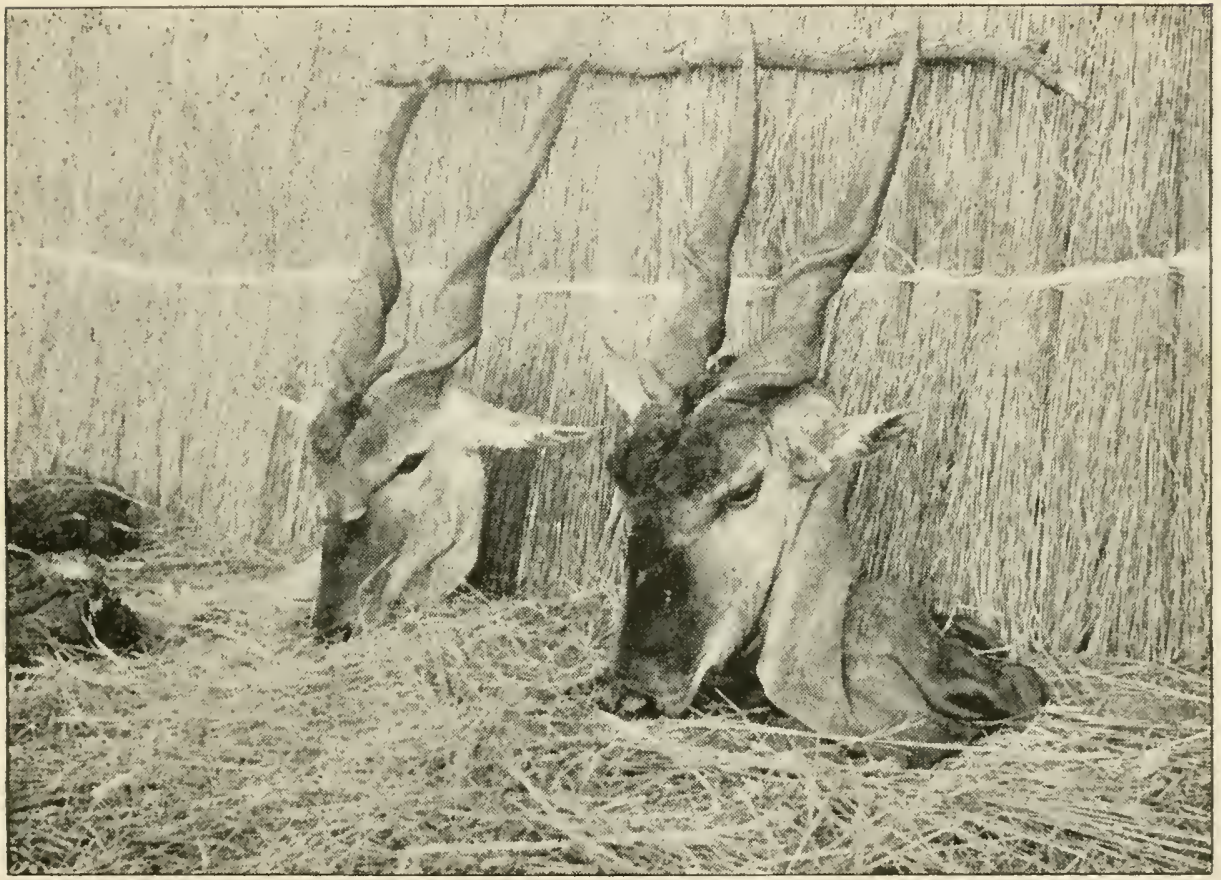

Frg. 133. - Pair of Eland Heads-striped variety.

hari and Southern Rhodesia, is without the white body stripes described above, while the striped northern race from the Zambesi northwards is called Taurotragus oryx livingstonei; this is the largest of the varieties and the bull is truly an enormous animal, weighing about 2,000 lbs. In Mashonaland the Elands have an indistinct white chevron on the face and a large brown tuft on the forehead (Taurotragus oryx selousi). These 
are merely geographical races, and they freely interbreed with one another in captivity. One young one is born annually. The young of the unstriped variety are distinctly striped for the first six or eight months of their lives.

As the Eland breeds well in captivity, and is as a rule of a mild docile nature, it is mysterious why no attempt

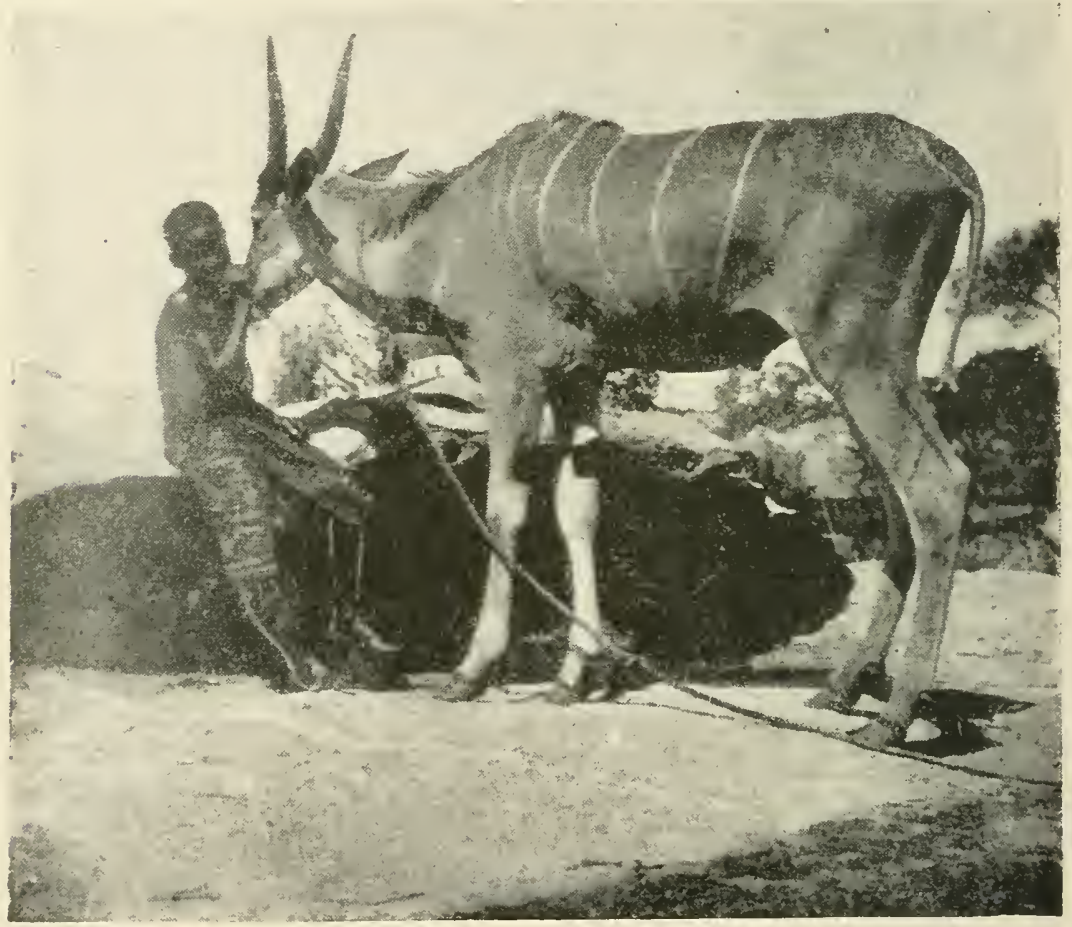

FIG. 134.--Young Eland just tamed (striped variety).

was made by our earlier settlers to domesticate this fine animal, even if only as a fresh item for the bill of fare. The Elands in the National Zoological Gardens breed regularly every year. The female Eland calls her young one by a soft bleating note, ridiculously inadequate for such a large animal.

It is a tough animal to kill and requires a well-piaced shot to bring it down. 
Sub-Family BOVINA.

\section{Genus BOS.}

Cattle-like animals of large size and stout build. Both sexes horned. Horns not ringed, but corrugated at the base and directed outwards. Female with four mammæ. No antorbital fossæ in the skull. Rhinarium wide.

Bos caffer. Cape Buffalo. Buffel.

'Nyati (Swazi and Zulu); Nadi (Bechuana and Barotse); Nari (Basuto).

Colour a dull black, the skin showing through the sparse black hairs. Ears fairly large and drooping, hairy behind.

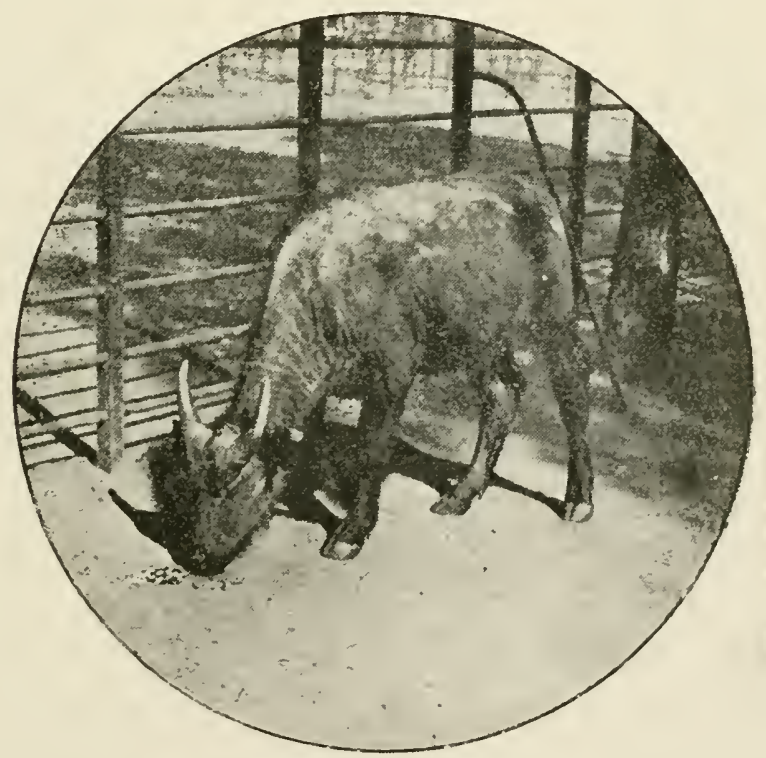

FIG. 135.-Young African Buffalo eight months old.

Hoofs round and broad. False hoofs well developed and pointed. Tail long, reaching to the hocks, and furnished with a fairly large brush at the end. The female is generally of a paler tinge, smaller, and with smaller horns than the male. Young reddish brown, becoming browner and then black at about 3 years old. The 


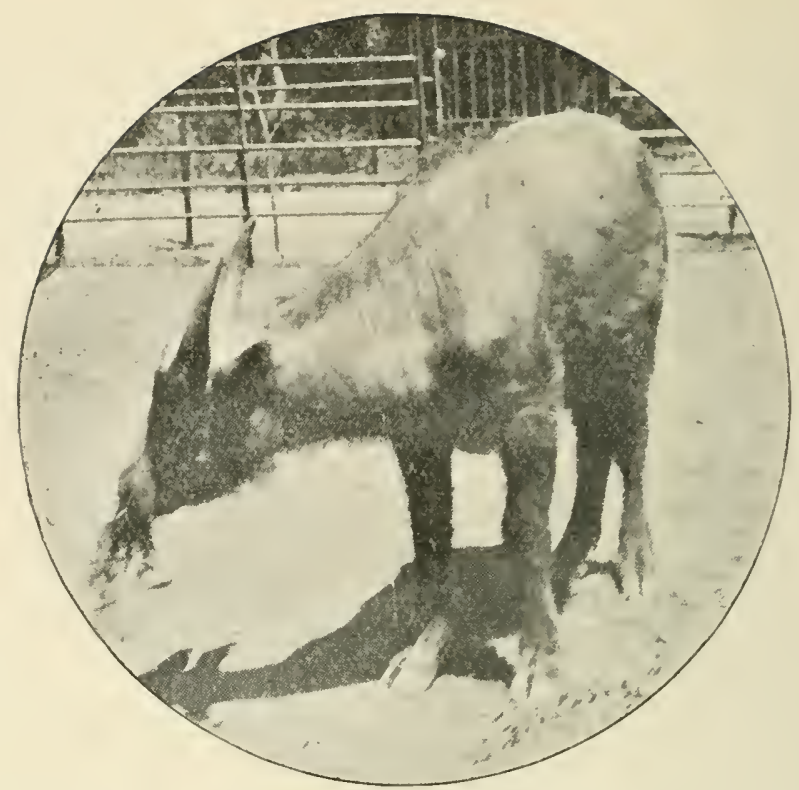

Fig. 136. - Young African Buffalo fourteen months old.

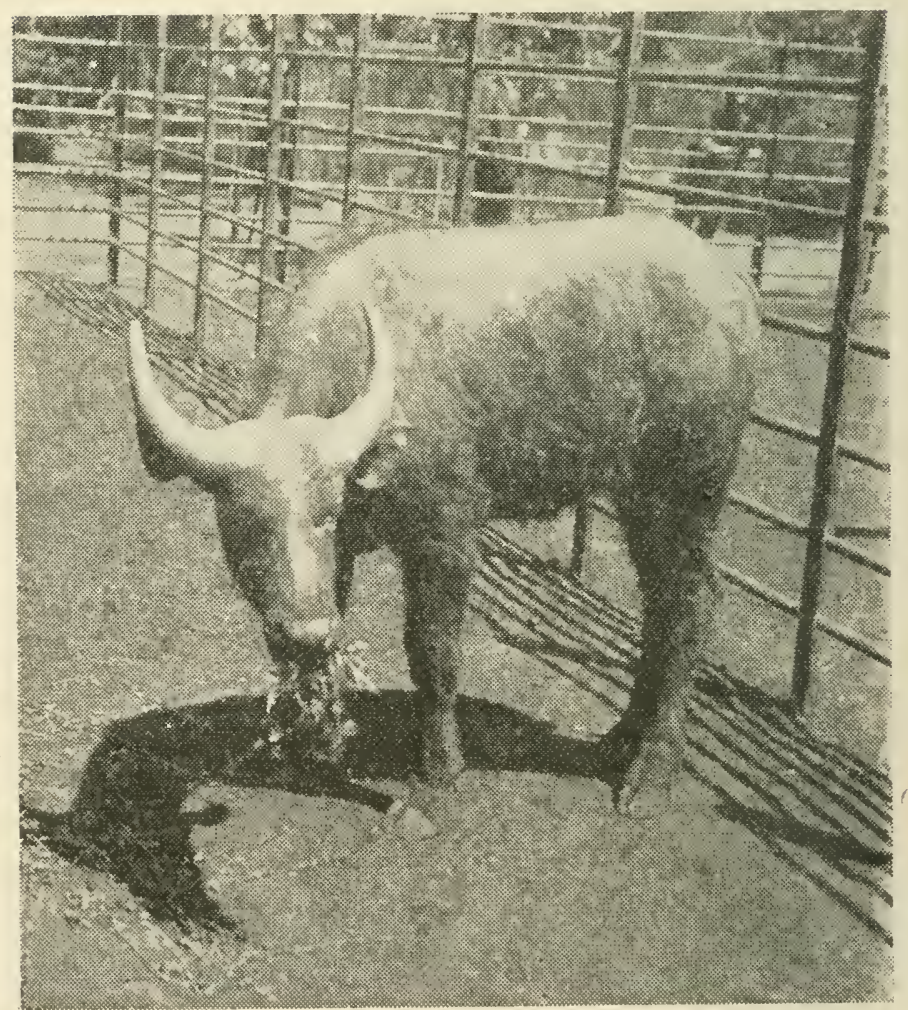

FIG. 137.-Young African Buffalo, two years old. 


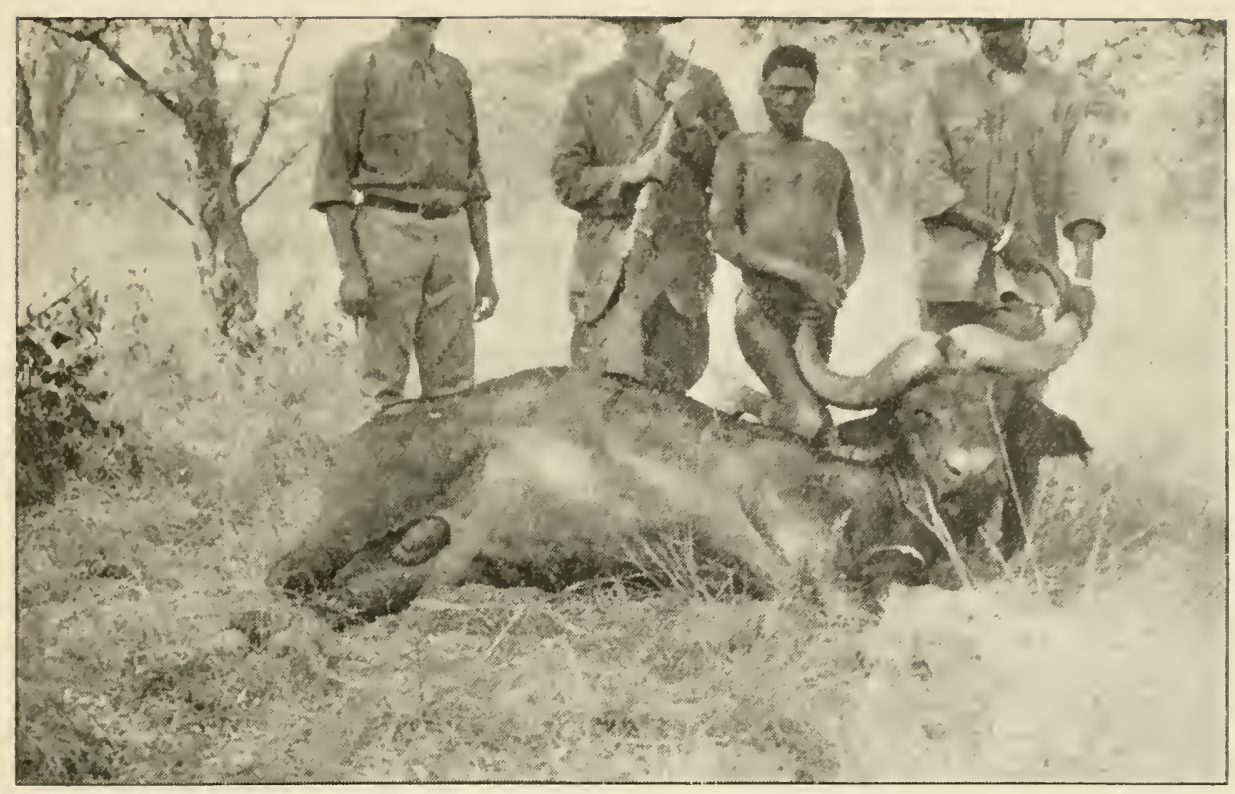

FIG. 13S.-African Buffalo (adult young animal).

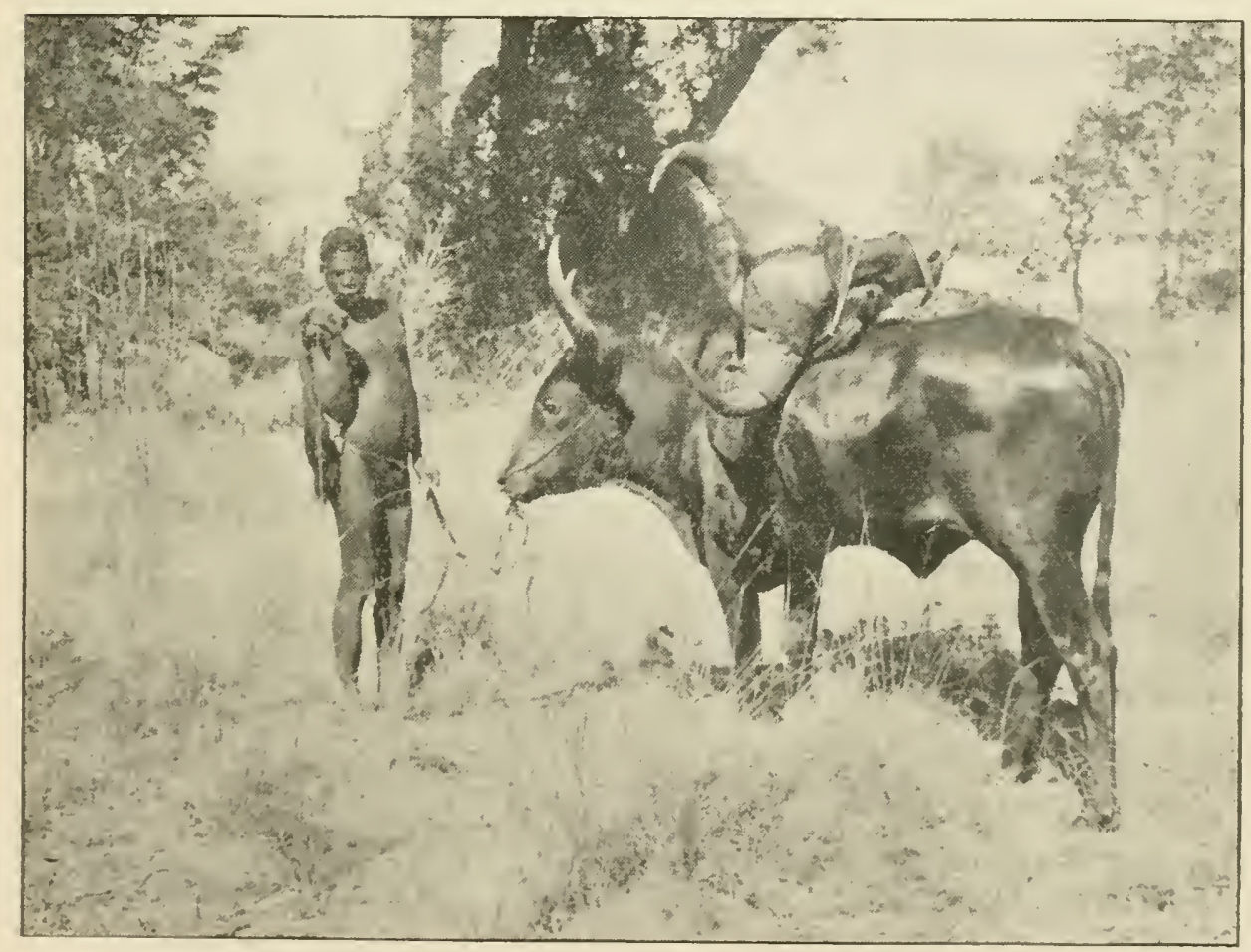

FIG. 139.-Head of African J3uftalo packed on bullock. 


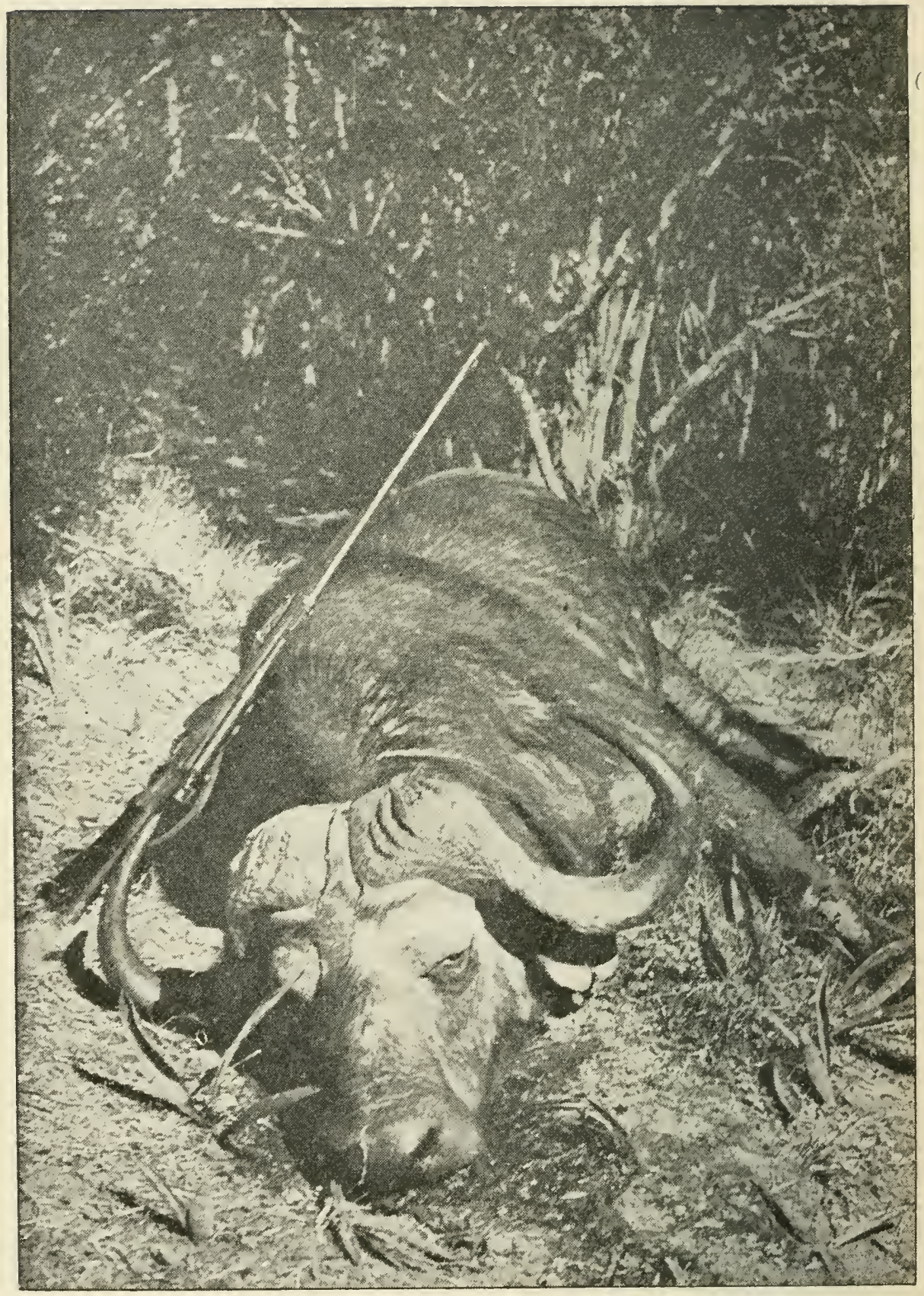

Fig. 140.-Cape Buffalo (Addo Bush, Cape Prov.). (Note the deep dcwnward sweep of the horns of the Cape animal as compared with the Rhodesian.) 
homs of the calf grow straight ont like those of the young Wildebeest, then downwards and finally outwards. I append three photographs of a young African Buffalo at the ages of $s$ and 14 months. Horns of the male very broad at the base, massive and corrugated, curved outwards and downwards, then upwards and inwards. Length about $2 !$ feet along the curve for bulls, and about 2 feet for cows. Record 41 inches; greatest width, outside $52 !$ inches.

At present the Buffalo is only found in the bushy and forest-clad districts of Albany, Alexandria, Bathurst and Uitenhage in Cape Colony, Zululand, South-West Africa, Rhodesia and Portuguese East Africa. There are still a few in the Sabi Game Reserves, and there is a large herd on Marianna Island in the Inkomati River near Delagoa Bay. It prefers thomy bush-clad well-watered country, where there are open glades. Although solitary bulls are not uncommon, the Buffalo usually congregates in herds of a dozen to as many as several hundred individuals. It is usually a dangerons animal to wound, and many lives have been lost in hunting Buffalo.

It is seldom found far from water, drinking at sunrise, and retiring to the bush or a reed thicket to sleep during the heat of the day. It drinks again at sunset, and loves to wallow in the mud. One calf is born at a time, during February or March, which remains hidden until it is about a fortnight old, after which it is strong enough to run with the herd. 


\section{Order SIRENIA.}

This is a small order of aquatic mammals containing only the two living forms - the Manatis and the Dugong, and the extinct Northern Sea Cow.

Like the Cetaceans, the Sirenians have the fore-limbs in the shape of flippers, have no hind limbs, and the tail is expanded horizontally into a steering paddle.

Unlike the Cetaceans however, the Manatis and Dugongs have depressed bodies, instead of as in the former where the body is compressed from side to side.

The muzzle is short, and the head more like those of ordinary mammals, being in proportion to the size of the body. There is no dorsal fin as in the whales. The females have two teats situated on the breast. The eyes are small and the ear orifice minute.

There is no Manati in South Africa, but as the Dugong has been repeatedly captured off the MIozambique coast it comes within the scope of this worls.

\section{Genus HALICORE.}

The tail is crescent shaped, and there are no traces of nails on the flippers. The nostrils are situated on the top of the snout and can be closed at will.

The skull is thick and has a massive beak-like projection at the extremity of the jaws, both the upper and lower of which are bent downwards. There are twenty-two teeth, consisting of a pair of incisors in the upper jaw, and five molars on either side of both jaws. The incisors in the male form downward projecting tusks, but those of the female are small. 
Halicore dugong. Dugong. Duyong.

Colour bluish grey, often inclining to whitish on the under parts. Length from 5 to 9 feet.

'The Dugong inhabits the shores of the Indian Ocean to about 20 south of the Equator and $15^{\circ}$ north.

It is purely a marine animal and never ascends rivers like the Manatis of America and West Africa.

Owing to their being constantly persecuted for the valuable oil which is obtained from their bodies, they are now getting scarce and wary and are only found in ones, twos or threes, whereas formerly herds of large size-up to a hundred or more, was a common occurrence.

Fishing for Dugongs is a regular industry on the Australian Coast. Its flesh is said to be quite tasty.

There is a skeleton of one in the Transvaal Museum presented by Capt. H. de Lacerda of Lourenço Marques. 


\section{Order CETACEA.}

This order embraces those mammals which have been modified for a wholly aquatic life, and include the Whales, Dolphins and Porpoises.

The head is long, with usually a wide mouth ; the body is fish-like, and there is no apparent neck.

At the posterior end of the body there are two horizontally placed fins resembling the tail of a fish, and which are known as flukes. There are no hairs on the body, which is smooth, and there are only a few bristles round about the mouth. In place of the hairy covering of the terrestrial mammals, these animals have a thick layer of fatty material under the epidermis; this is known as the blubber, and forms a lucrative article of commerce, for which the unfortunate whales are continually being hunted.

The skull has a rounded brain-case, with a beak-like rostrum; the teeth, when present, are simple and uniform and are not preceded by milk teeth.

\section{Sub-Order MYSTACOCETI.}

Whales with the palate provided with a large number of plates of baleen (so-called whalebone), and with teeth never developed after the birth of the animal.

Sternum or breastbone composed of a single piece, and connected to only one pair of ribs.

Family BALÆNID蚱.

\section{Genus BALÆNA.}

The skin of the throat is smooth, and there is no dorsal fin. 
Balæna australis. "Southern Right Whate. Zuidlik Opregte Walvis.

The head is large, and the upper lip is acutely arched. Colour, black throughout. Length, 60 to 70 feet; head, 16 feet; width of tail, $15 \frac{1}{2}$ to 16 feet.

This whale wanders into the Cape bays during the winter months to calve. It feeds unon the minute crustacea and mollusca which are found floating on the surface of the sea in large numbers.

\section{Genus MEGAPTERA.}

Head moderate and flat, with the jaws almost straight. There is a long dorsal fin situated on a small hump on the back. Flippers, long and narrow. Tentral surface of body ridged and furrowed.

Megaptera longimana. Huvipback Whale. Bockelrug Walvis.

Upper surface and sides of body black; front portion of lower surface white; rear portion mottled black and white. Pectoral fins scalloped along the bottom edge; white below and black above. Length of head and body, 35 feet. Tength of pectoral fins, 9 feet.

This Whale ranges from the Northern Atlantic to the North and South Pacific Oceans. It is found nearly all over the world. This species also comes into Table and False Bays to breed in the winter months, and, as the blubber is not thick, while the whalebone is short, it is not often hunted by the whalers of the Cape.

\section{Genus BALENOPTERA.}

Head small and flat, pointed anteriorly; skin of the throat plicated. A strong dorsal fin is present, and the pectoral fin is small and narrow. 
The species of fin whale inhabiting the Cape coastal seas is still uncertain.

\section{Sub-Order ODONTOCETI.}

Teeth always present, but no baleen; breastbone in several pieces and joined to several pairs of ribs.

\section{Family PHISETERIDE.}

No actual teeth in upper jaw. Four genera.

\section{Genus PHYSETER.}

Large massive animals, with an enormous head. Upper teeth rudimentary and of no practical use.

Physeter macrocephalus. Sperm Whale or Cachelot.

Head blunt and square in front (truncate). Colour blackish with green reflections; below, greyish. Abdomen and tail sometimes marked with white. The head contains an oily substance linown as spermaceti, hence the popular name of this whale. Length, 55 to 60 feet.

The Sperm Whale ranges throughout the oceans, excepting the Polar Seas, being commonest in the warmer climes.

It feeds upon Cuttle and other Jelly-fish, besides scalefish of the Rock Cod type, ic. The young are born out at sea.

There are three other genera inhabiting the Cape seas: Kogia (with one species), Ziphius (one species), Mesoplodon (two species). Of the latter, Layard's Beaked Whale (M. layardi) was described from a specimen (the type) obtained by Mr. Layard in the Cape. Colour, black above and white below. Length 18 feet. 


\section{Family DELPHINIDA:}

This family is the largest of the Order, and is characterized chiefly by the large number of teeth in both jaws. 'There are eleven genera: Grampus, Globicephalus Neophocenu, Orcinus, Lagenorhynchus, Cephalorhynchus, Dephinus, Tursiops, Prodelphinus, Steno and Sotalia.

Of the above, the following are the best known:-

Orcinus orca. The Killer Whale.

Of a black colour above and white below, and with a stripe over the eye. Dorsal fin large and pointed, and pectoral fin broad and short. Length, 19 or 20 feet. This is a fairly cosmopolitan species, and is of a rapacious nature, devouring seals, porpoises, young whales, \&c., being the only Whale or member of the Cetacea which preys ripon other warm-blooded animals, although it also devours fish.

\section{Delphinus delphis. Common Dolphin.}

Slate-colour above, grey below, a yellowish grey stripe from behind the eye to the level of the dorsal fin. An elongated, beak-like snout. Total length, 7 to 8 feet. This animal is pretty generally distributed throughout the warmer seas, and associates in herds or shoals of from six individuals upwards. 'They are playful, energetic animals, rising to the surface of the sea every now and then, playing and gambolling round ships, \&c. Only a single young one is born at a time.

The members of the other genera are rare. 


\section{Order EDEN'TATA.}

This is a small order, containing the degenerate remnants of a former age which were common, especially in South America.

The teeth are never rooted, but grow from persistent pulps, and consist of dentine and enamel only. There are no incisor teeth. There are five families, only two of which are found in the Old World.

\section{Family MANIDA.}

\section{Genus MANIS.}

Manis temmincki. Scaly Ant-eater or Pangolin. Yzer IIagaauw.

A medium-sized animal with a rather elongated form. Body covered above and on the sides with a series of horny scales or plates overlapping each other. Limbs short and also covered with scales, the forefeet supplied with long claws, both fore and hind feet with five toes. The head is very small, and without an external ear; mouth small and devoid of teeth, and the tongue is long and extensile. Tail broad and paddle-like, also covered with scales. Length of head and body, 2 feet; tail, $1 \frac{1}{2}$ feet.

This peculiar animal extends from the region of the Orange River northwards to Somaliland.

It burrows in the ground, and prefers the drier parts of the country. Its chief food is ants and termites, which it obtains by digging into anthills and termite nests. When alarmed, it rolls itself into a ball, trusting to its horny covering to protect it. 
A number of examples have been sent to the National Zoological Gardens, chiefly from the Rustenburg and Marico districts of the 'Transvaal, and several females with a young one. As I have never seen more than one young one with a female, I presume this is the full complement. The mother protects the youngster, when small, by rolling herself round it, i.e., embracing it between her feet.

We have not managed to keep this animal for any length of time in captivity, even when efforts were made to keep it supplied with its natural food of ants. It seems to mope badly.

\section{Family ORICTEROPODIDA.}

\section{Genus Orycteropus.}

Orycteropus afer. Antpig or Antbear. Aardvark.

A plump, pig-like animal, with short legs and thick tail. Head elongated, and with a pig-like snout. The tongue is viscid. The ears are long and erect. The body, which is not well covered with hairs, varies from a dim yellow to a yellowish brown colour. The legs are provided with strong claws, and are clothed on the outer surface with long brown hair. Length of the head and body, from it to $4 \frac{1}{2}$ feet; tail, 17 to 24 inches.

This animal is not at all uncommon in certain districts, but, on account of its nocturnal habits, is seldom seen. It excavates large burrows in the earth, in which it lives. These are usually to be seen in the more open and flat country where antheaps abound, as the inhabitants thereof and their larvæ are its chief food. An opening is made in the sides of the antheap, and the inmates abstracted by means of its long and sticky tongue. 
It is a timid animal, with excellent powers of hearing. Its flesh is said to be good eating, although the author has never brought himself to try it.

It is a very difficult animal to keep alive in captivity, but, when captured young, can be trained to subsist on a

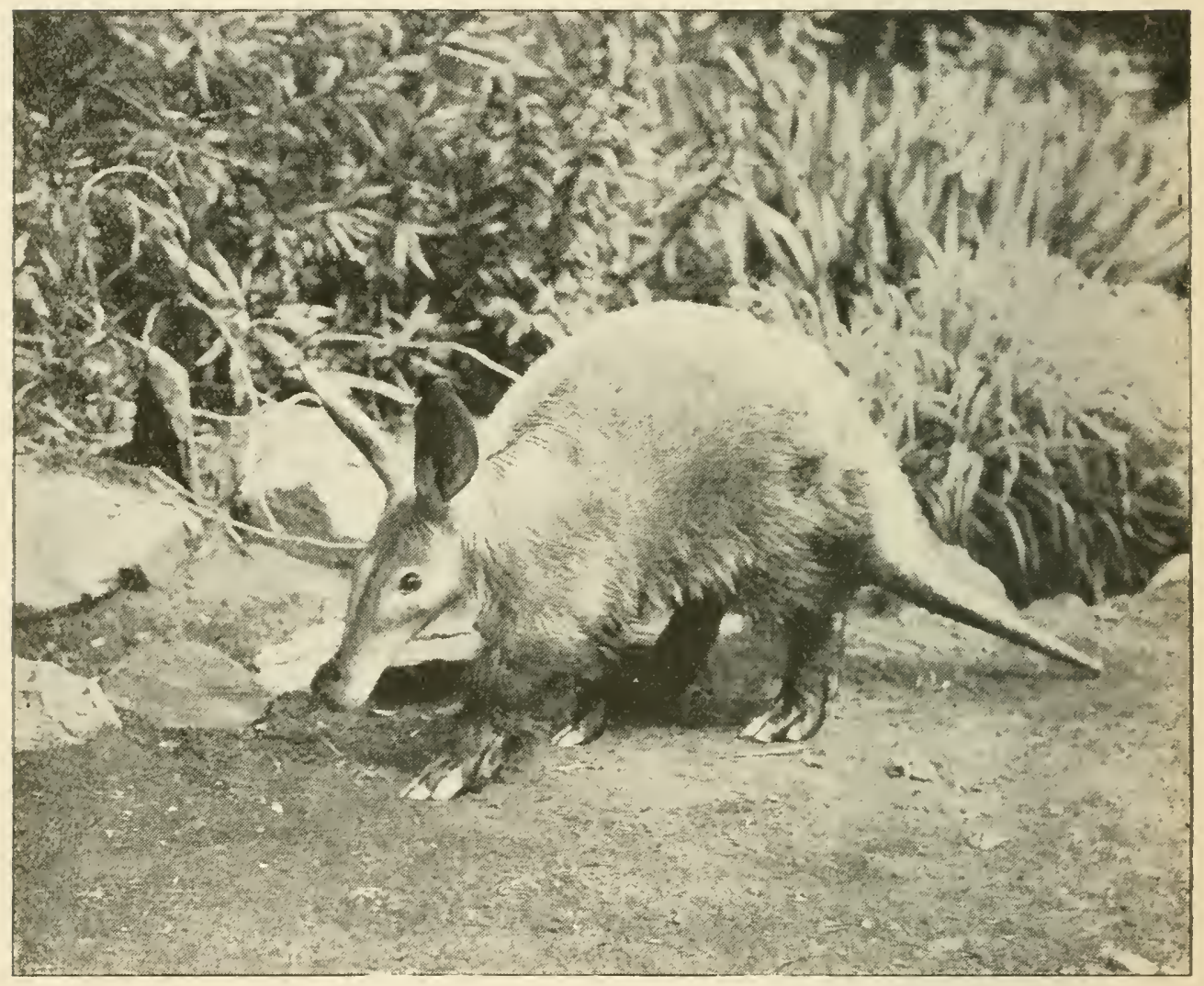

FrG. 141.-Antbear or Aardvark.

gruel made of mealie meal porridge, milk and raw eggs. The first one we got to do so went to the London Zoo with the King's collection, after we had it for a year. I never heard how long it survived its sea voyage. The second individual which took kindly to its captivity escaped from its cage through the carelessness of the native keeper, after we had had it over six months. In 
the subsequent exciting chase and final recapture the animail must have been injured, as it refused nourishment and died a few days later. I append a photograph of the second one. There is a picture of the first one in Major Stevenson Hamilton's book, "Animal life in Africa." 


\section{NAME INDEX.}

Aap, Bosch, 17

Aardvark, 237

Aardwolf, 50

Acomys, 98

Exyceros melampus, 193

African elephant, 112, 113

Afrikaanse olifant, 113

Amblyosomus, 33

American grey squirrel, 88

Animals, classification of, 1, 2

Antbear, 237

Ant-eater, scaly, 236

Antelope, 171

- harnessed, 208

- impala, 193

- Lechwe, 185

- Livingstone's, 182

- oribi, 178

- puku, 187

- roan, 200

- sable, 201

Antidorcas euchore, 195

Antpig, 237

Apes, 4

Arctocephalus capensis, 83

Arvicanthus dorsalis, 98

- pumilio, 98

Augur bat, 24

Baboon, chacma, 11

- Rhodesian, 14

- yellow, 9

Badgers, 35

Balana australis, 233

Balanoptera, 233

Banded mongoose, 62

Bastard eland, 200

- hartebeest, 165

- koedoe, 209

Bat, 21, 26

- fruit, common, 23

- - epauletted, 22

_ - yellow, 23
Bathyergus maritimus, 99

Baviaan, 11

— geele, 9

- Rhodesies, 14

Berg zebra, 139

Blaauwap, 4

Blaauwbokkie, 172

Blaauw wildebeest, 166

Black-backed jackal, 41

Blackfooted cat, 75

Black or prehensile-lipped rhinoceros, 126

Black rat, 94

Black-spotted genet, 56,57

Black wildebeest, 168

Blesbuck, 162

Blesniol, 100

Blue duiker, 172

- wildebeest, 166

Boekelrug walvis, 233

Bokje, Livingtone, 182

Bontebuck, 160

Bonte quagga, 129

Booceros, 209

Boom dassie, 111

-. muizen, 93

Bosbok. 207

Bos caffer, 225

Bosch aap, 17

- kat, tier (tijger), 78

- staart muisen, 89

Bosvark, 142

Brown hyaena, 51

- rat, 94

- vlei rat, 93

Bruce's rock rabbit, 110

Bruin mol, 100

Bubalis caama, 157

- lichtensteine, 159

Buffalo, Cape, 225

Buffel, 225

Burchell's Zebra, 129

Bushbaby, 17, 18 
Bushbuck, Cape, 207

Bush hare, 108

Bushpig, 142

Cachalot, 234

Caffre cat, 73

Cane rat, 102

Canis, 41

- lateralis, 42

- mesomelas, 41

Cape buffalo, 225

- bushbuck, 207

- dormouse, 91

- elephant shrew, 28

- fur seal, 82

- golden mole, 34

- hare, 107

- horseshoe bat, 24

- hunting dog, 15

-.- jumping hare, 101

- long-eared fox, 48

— otter, 39

- polecat, 37

- rabbit, 106

- sea lion, 82

- slit-faced bat, 25

— wild cat, 73

Caracal, 79

Caracal nubica, 79

Cat, blackfooted, 75

—, civet, 53

-, tiger, 78

Cephalophus grimmia, 173

- monticola, 172

- natalensis, 171

- robertsi, 172

Cercopithecus lalandei, 5

- pygerythrus, 4

- - rufoviridis, 5

Chacma baboon, 11

Cheetah, 66

Chestnut tree mouse, 93

Choiropithecus porcarius, 11

- rhodesia, 14

Chrysochloris, 33

-- aurea, 34

- hottentota, 34

Civet cat, 53

Cobus ellipsiprymmus, 181
Cobus leche, 185

- vardoni, 187

Common dolphin, 235

- duiker, 173

Coneys, 109

Connochaetes gnu, 168

- taurinus, 166

Cotilophora, 152

Crawshay's zebra, 137

Cricetomys gambianus, 96

Crocidura, 31

- flavescens, 33

- silacea, 33

- varilla, 31

Crossarchus faciatus, 62

Ctenodactylida, 102

Cynailurus jubatus guttatus, 66

Cynictus penicillata, 63

- selousi, 64

Damara dikdik, 183

- dwergbokje, 183

Damiliscus albifrons, 162

- lunatus, 165

- pygargus, 160

Dassie, 109

Dasymys, 98

Delphinida, 235

Delphinus delphis, 235

Dendromys, 93

- melanotis, 94

- mesomelas, 93

- pumilo, 93

Diceros, 124

- bicomis, 126

- simus, 125

Dolphin, cornmon, 23

Dormouse, 89

-- Cape, 91

- grey, large, 91

Draai jakhals, 48

Dugong, 231

Duiker, blue, 172

— bok, 173

- common, 173

- red or Natal, 171

Duinmol, 99

Duplicidentata, 86

Dwarf shrew, $3 \mathrm{l}$ 
Dwerg kommetje kat, 61

- langsnoet muis, 31

Eland, 221

- bastard, 200

Elephant, African, 112, 113

- seal, 84

Elephas afvicanus, 113

Eosaccomys campestria, $9 \mathrm{~s}$

Epauletted fruit bat, 22

Epomophorus, 22

- crypturus, 23

- vahlbergi, 22

Erinaceus, 29

- frontalis, L., 29

"Fat mouse," 99

Felis cafjra, 73

- chans, 74

- leo, 68

- nigripes, 75

Field mouse, 96

— striped, $9 \mathrm{~s}$

Fissipedia, 35

Fox, long-eared, Cape, 48

- silver, 44

Fruit bat, 22, 23

Galago granti, 19, 20

- moholi, 18

- mossambicus, 19

Geel mierkat, 63

- waterbok, 185

Geele caviaan, 9

Gele eckhoorntje, 87

Gemsbuck, 205

Genet, black-spotted, 56, 57

- rusty-spotted, 55, 57

Genetta, $5 \pm$

- felina, 57

- letabce, 55

- ludia, 57

- rubiginosa, 55

- tigrina, 56

Georychus capensis, 100

- damarensis, 101

- darlingi, 101

- hottentotus, 100

- nimrodi, 101
Geosciurus capensis, $8 \mathrm{~S}$

Gerbilles, 92

Gestreepte kommetje kat, 62

- muizen, 98

Gevlekte otter, 40

— wolf, 52

Giant rat, 96

Givaffa, $15 ?$

- capensis, 153

Giraffe, Southerm, 153

Gnu, white-tailed, $16 \mathrm{~S}$

Golden jackal, 41

- moles, 33

Graatje mierkat, 64

Grant's moholi lemur, 20

- nachtaapje, 20

Grap7inurus eastwoodce, 90

- muninus, 91

- ocularis, 91

-- pretorice, 90

Grey dormouse, large, 91

- footed squirrel, 87

- mongoose, 5S, 60

- monkey, 4

- rhebuck, 192

- shrew, 33

- tree mouse, 94

Grijsbok, 180

Grijse dassie, 110

Grizzled steenbuck, 182

Groot roodgevlekte mosiliaat kat, 55

- rot, 96

- vaal muishond, 58

— zwarte muishond, 59

- zwartgevlekte mosiliaat kat, 56

Ground squirrel, 88

Grysbuck, 180

Gymmura, 29

Haarstaart muizen, 92

Halicore, 230

Halicore dugong, 2:31

Hare, bush, 108

- Cape, 107

- thick-tailed, 106

Harnessed antelope, 208

Hartebeest, bastard, 165

- Lichtenstein's, 159

- red, 157 
Hartmanne, 140

Hedgehog, South African, 29

Helogale, 61

Herpestes albicauda, 60

- brunnula, 61

- caffer, 58

- galer $a, 59$

- gracilis, 60

- parvula, 61

- pulverilentus, 60

- punctatissimus, 61

- ruddi, 61

Hippopotamus amphibius, 146

Hipposiderus caffra, 25

- commersoni, 25

Hippotigris burchelli, 129

- - antiquorum, 131

- chapmanni, 133

- _ selousi, 133

- - transvaalensis, 131

- - typicuss, 131

- - vahlbergi, 131

- crawshayi, 137

- zebra, 139

Hippotragus equinus, 200

- niger, 201

Honey-badger, 36,

Honing das, 36

Horseshoe bat, European, 24

House-mouse, 94

Humpback whale, 233

Hunting dog, 45

-- leopard, 66

Hyaena, 51

- brunnea, 51

- capensis, 52

- crocuta, 52

Hyaena, brown. 51

- spotted, 52

Hystricomorpha, 86

11 y strix, 103

- africa-australis, 104

Ibawara (Lower Kambesi), 207

Ictonyx capensis, 37

Igama (Makalaka), 157

Ihuhla (Zulu), 15:

Ijzer-vark, 101

Ikokoni (Basuto), 166
Ikumi (Basuto), 176

Ilieza (Swazi), 192

Imfele a nata (Bechuana), 1 s9

Impala antelope, 193

Impulupudi (Basuto), 181

Indhlubamiti (Swazi), 153

Infele (Bechuana), 191

Ingaina (Swazi), 181

Ingululu (Makalaka), 176

Inklengana (Amatonga), 182

Inkongoni (Swazi and Zulu), 166

Inkonka and Imbabala (Swazi and Zulu), 207

Inkulando (Mashona), 159

Inla (Swazi and Zulu), 178

Ipietie (Zulu), 172

Iputi (Basuto and Bechuana), 173

Iquini (Zulu), 181

Isikupi (Basuto), 180

Itolo (Basuto), 217

Jacht tier, 66

Jackals, 41

Kaapse konijn, 106

Kaapsche otter, 39

Kaboli (Barotse), 165

Kameel, 153

Khama (Bechuana), 157

Killer whale, 235

Klein gevlekte kat, 75

- grys kommetje kat, 60

- roodgevlekte mosiliaat kat, 57

- wilde paard, 137

- zwartgevlekte mosiliaat kit, 57

Klipbok, 176

Klip das, 109

Klipspringer, 176

Koedoe, 217

- bastard, 209

- water, 211

Koyia, 234

Kokong (Larotsc), 166

Kokotombini (Barotse), 159

Kol haas, 108

Kommetje lat, 59

Konzi (Chilala), 159

Koodoo, 217

Krimp ijzervarkic or ijgeltje, 29 
Kring-gat, 184

Kualata tchumu (Ngami, Bechuana), 201

Kudu, 217

Kukama (Bechuana), 205

Kwalata (Bechuana), 200

Lechwe antelope, 185

Leeuw, 68

Leggada deserti, 96

- minutoides, 96

Lemur, 17-20

- moholi, 18

- thick-tailed, 17

Leopard, 76

- hunting, 66

Leopardus pardus, 76

Lepus, 106

- capensis, 107

- monticularis, 107

- ochropus, 107

- saxatilis, 108

Lichtenstein's hartebeest, 159

Liegwhi (Makololo), 185

Ligoka (Zulu and Swazi), 176

Lion, 68

Li-Tumago (Matabili), 184

Livingstone's antelope, 182

Long-eared fox, Cape, 48

Long-tailed bat, 26

Long-winged bats, 26

Luipaard, 76

Lutra capensis, 39

- maculicollis, 40

Lycaon pictus venaticus, 45

Lymmotragus, 214

Lynx, South African, 79

"Macloutsie," 49

Macrorhinus leoninus, 84

Macroscelines, 27

- proboscideus, 28

- rupestris, 28

Madoqua damarensis, 183

Manhaar jakhals, 50

Manis temmincki, 236

Natschie's zambesiana, 57

Matuti (Barotse), 184

I'babala (Barotse), 207
Mcolomo (Matabele), 165

Meercat, yellow

Megaptera longinana, 233

Mellivora ratel, 36

Melothrix, 94

Mesoplodon, 234

Nice, 91

- field, 96, 98

- tree, 93

- white-tailed, 99

Mierkat, true, 64

Miniopterus, 26

-natalensis, 26

Mikumbi (Zulu), 171

Mof or Vaal hartebeest, 159

Mofo (Mashona), 221

Moholi lemur, 18

- Grant's, 20

- Peter's, 19

Mole, golden, 33

- rat, 100

- sand, 99

- - star, 100

Mongoose, banded, 62

- grey, 58, 60

- pigmy, 61

- slender, 60

- thick-tailed, 63

— water, 59

- white-tailed, 60

Mongos, 61

Monkey, 4-17

- grey, 4

- Mozambique, 7

- Natal, 4

- samango, 8

- vervet, 4

Mona albigularis, var. beirensis, 7

- samango, 8

Mosiliaat katten, 55

Mountain zebra, 139

Mouse, see Mice

Mozambik aap, 7

Mozambique monkey, 7

'MIpofu (Barotse and Ngami), 221

Ipunzi (Zulu and Stvazi), 173

'MItagaisi (Zulu), 200

Muishond, 37, 38

Muizen, 91 
Muntinya (Barotse), 187

Muss, 94

- coucha, 95

- decumanus, 94

- minutoides, 96

- musculus, 94

- rattus, 94

MIuskus kat, 5.3

Nutubo (Barotse), 189

Muzefu (Mashukulumbwi;, 221

Myomorpha, 86

Myosorex, 33

- varius, 33

Mystromys albipes, 99

Mzanzi (Swazi and Zulu), 165

Mrikie (Matabele and Zulu), 189

Nzumbi (Swazi), 171

Nachtaapje, 18

-- Peter's, 19

Nadi (Bechuana and Barotse), 225

Nakong (Lake Ngami), 214

Nalufwa (Mashukulumbwi), 189

Nari (Basuto), 225

Narja (Mashukulumbwi), 185

Natal duiker, 171

- monkey, 4

Nesotragus livingstonianus, 182

N'gla (Swazi), 191

Ngulubi-e'-Tschlati (Swazi), 142

Nhlango (Swazi), 189

Night ape, 18

Noki rot, 102

Noordelike berg zebra, 137

Noro (Mashona), 217

Northern mountain zebra, 137

Nschlongololo (Swazi and Zulu), 217

Nunni (Bechuana), 162

'Nyala (Zulu and Swazi), 209

'Nyati (Swazi and Zulu), 225

Nycteris, 25

- capensis, 25

Nyctinomus, 26

- agytiacus, 26

-.. limbatus, 26

Orcinus orca, 235

Oreotragus oreotragus, 176

Oribi antelope, 178
Orycteropus afer, 237

Oryx gazella, 205

Otocyon megalotis, 48

Otolemur crassicaudatus, 17

- garnetti, 18

Otomys, 92

- brantsi, 93

- broomi, 93

- irroratus, 93

- sloggetti, 93

- unisulcatus, 93

Otter, 35

- Cape, 39

- spotted-necked, 40

Ourebia ourebi, 178

Pachyuromys auricularis, 92

Pala (Basuto and Bechuana), 193

Pangolin, 236

Panther, 66

Papio cynocephalus, 9

Paraxerus cepapi, 87

- congicus, 88

- palliatus, 88

Pecora, 152

Pedetes caffer, 101

Pediotragus horstocki, 181

- sharpei, 180, 182

- tragulus, 180

Peelie (Bechuana), 192

Pelea capreolus, 192

Petalia, 25

Peter's Moholi lemur, 19

- nachtaapje, 19

-- wrinkle-lipped bat, 26

Petrodromus, 28

Petromys typicus, 102

Phacochœrus, 143

- cethiopicus, 144

Phuduhudu (Bechuana), 181

Physeter macrocephalus, 234

"Pietic," 172

Pigmy mongoose, 61

Pigs, 142

- bush, 143

Piva (Swazi), 181

Poecilogale albinucha, 38

Pofo (Bcchuana), 221

Polecat, Capc, 37 
Porcupine, South African, 104

Potamocherus chæropotamus, 142

Potoquani (Southern Bechuana), 201

Procavia arborea, 111

- brucei, 110

- capensis, 109

Pronolagus, 106

- crassicaudatus, 106

Proteles, 49

- cristatus, 50

Puku antelope, 187

-- bok, 187

Pudukudukameni (Basuto), 178

Rabbit, Cape, 106

- rock, 109

- - Bruce's, 110

- - tree, 111

Ratel, the, 36

Rats, 91

-, black, 94

-, brown, 94

-, cane, 102

-, giant, 96

—, mole, 100

-, rock, 102

一, water, 92

—, white-nosed, 95

Red duiker", 171

-- golden mole, 34

- hartebeest, 157

- -headed squirrel, 88

— rhebuck, 191

Rednnca arundinum, 189

- fulvorufula, 191

Reedbuck, 189

Reuzen rot, 96

Rietbok, 189

Riet rot, 102

Rhebuck, grey, 192

-., red, 191

Rhinuceros, black or prehensile, 126

- square-mouthed, 125

Rhinolophus augur, 24

- capensis, 24

- darlingi, 24

- denti, $2 t$

- ferrum-equinum, 24

- hildebrandi, 24
Rhodesian baboon, 14

- - skull of, measurements of, 16

Rhodesies baviaan, 14

Roan antelope, 200

Robbe, 82

Rock elephant shrew, 28

- hare, $10 \mathrm{~s}$

-- rabbits, 109

- rat, 102

Rooibok, 193

Rooi bos-bokje, 171

- chebok, 191

- duiker, 171

- haas, 106

- hartebeest, 157

— jakhals, 41

- kat, 79

- mierkat, 60

Rotten, 91

Rousettus, 22

- collaris, 23

- straminerus, 23

Rusty-spotted genet, 55,57

Sable antelope, 201

Saddle-backed jackal, 41

Samango aap, 8

- monkey, 8

Sand mole, 99

- star, 100

Scaly ant-eater, 236

Schimmel bokje, 182

Sciuromorpha, 86

Sciurus carolinensis, 88

Seabear, 82

Seadog, 82

Sea elephant, 84

Sealion, Cape, 82

Seal, 82

-, elephant, 84

-, true, or earless, 81

Serotine bats, 26

Serval, 78

Sessaby, 165

Sharpe's steenbuck, 182

Shiatla (Basuto), 192

Shrew, dwarf, :31

- large, 33

Side-striped jackal, 42 
Silver fox, 44

- jackal, 41

Simplicidentata, 86

Sitatunga (Barotse), 214

Sitchisunu (Mashukulumbwi), 187

Sithlengone (Sivazi), 182

Skearer muis, 33

Slang muishond, 38

Slender mongoose, 60

Slit-faced bats, 25

Suake weasel, 38

Soricince, 30

South African hedgehog, 29

- - lyux, 79

— - porcupine, $10 \dot{x}$

Southern giraffe, 153

-- right whale, 233

Sperm whale, 234

Spotted hyaena, 52

Spotted-necked otter, 40

Springbuck, 195

Springhare, 101

Square-mouthed rhinoceros, 125

Squirrel, grey, American, 88

-, grey-footed, 87

--, ground, 88

-., red-headed, 88

-, striped, 88

--, yellow, 87

Star sand mole, 100

Steatomys, 94

Steenbuck, 181

-, grizzled or Sharpe's, 182

Stink muishond, 37

Stokstaart mierkat, 64

Strand jut or wolf, 51

Strepsiceros capensis, 217

Striped field mice, 98

- squirrel, 88

Sukwe (Zulu), 17

Suricata tetradactyla, 64

Takiaasi (Swazi), 200

Taphozous, 26

Tatera, 92

- afer, 92

- brantsi, 92

- lobengula. 92

- paeba, 92
'Taurotragus oryx, 221

- - livingstonei, 223

- oryx, 223

- selousi, 223

Thick-tailed lemur, 17

- mongoose, 63

" 'Thos," 41

Thryonomys swinderianus, 102

Tier, 66

-- bosch kat, 78

"Tiger," 76

- cat, 78

— wolf, 52

Tijger, 66, 76

Tolo (Bechuana and Barotse), 217

Tragelaphus angasi, 209

- scriptus, $20 \mathrm{~S}$

- selousi, 214

- spetiei, 214

- sylvaticus, 207

Transvaal Grijsbokje, 182

Tree mice, 93

— rock rabbit, 111

True mierkat, 64

Tsessebi, 165

Tsipi (Bechuana), 195

Tumoga (Bechuana), 184

Tuthla (Basuto), 153

Ungwena (Ma tabele), 181

Vaal boschkat, 73

- jakhals, 42

— rhebok, 192

Vertebrate animals, 2

Vervet monkey, 4

Vespertilio, 26

- capensis, 26

Viverra civetta, 5:3

Vlak haas, 107

Vlakvark, 144

Vlei rotten, 92

Vulpes, 43

- chama, 44

Waaierstraart, 88

Warthog, 144

Waterbuck, 184

IVater koedoe, 214 
Water mongoose, 59

- rats, 92

Weasel, 35

一, suake, 38

Whale, humpback, 233

-. killer, 235

- southern right, 233

- sperm, 234

"White rhino," 125

White-nosed rat, 95

White-tailed guu, 168

- mongoose, 60

- mouse, 99

Wild eat, Cape, 73

Wildebeest, 168

-, blue, 166

Wilde kat, 73

- hond, 45

- paard, 139

Witstaart kommetje kat, 60

Witte rhenoster, 125

"Wolf," 52

Wrinkle-lipped bat, brown, 26

Xosa (Matabele), 173

Yellow baboon, 9
Yellow fruit bat, 23

- meereat, 63

- squirrel, 87

Yzer magaauw, 236

Zambeziana, Matschie's, 57

Zand mol, 99

Zebra, Burchell's, 129

- Crawshay's, 137

- mountain, 139

- northern mountain, 137

Zebroid, 136

Zee koe, 146

Zeeleeuw, 82

Zee-olifant, 84

Zeven-slaper, 89

Zibethailurus serval capensis, 78

Zilver jakhals, 44

Ziphius, 234

Zoology, general principles of, 1

Zorilla striata, 37

Zuidlik opregte walvis, 233

Zuluensis, 108, 183

Zwarte rhenoster, 126

- wildebcost, 168

- witpens, 201 




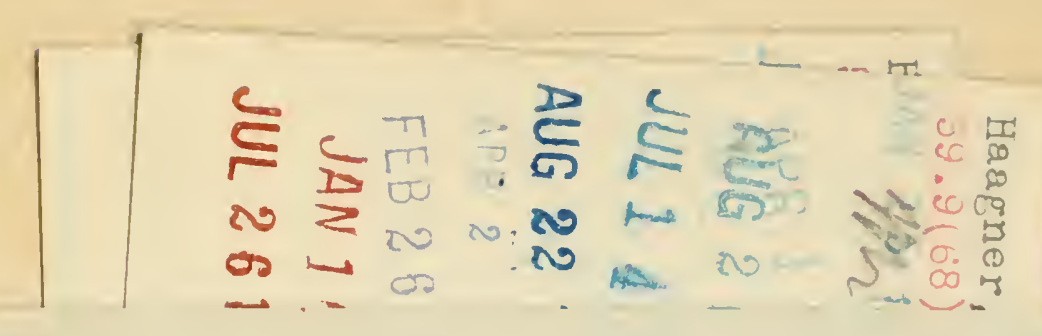


